\author{
UNIVERSIDAde de SÃo PAUlo \\ ESCOLA DE ENGENHARIA DE SÃo CARLOS \\ DEPARTAMENTO DE TRANSPORTES
}

\title{
AVAliação Laboratorial de Misturas Asfálticas densas Modificadas COM Borracha Reciclada de Pneus
}

SANdRA A. MARgarido Bertollo

TESE APRESENTAdA À Escola DE ENGENHARiA DE SÃO CARlos DA Universidade DE SÃO PAULO PARA OBTENÇÃO DO TÍTULO DE DOUTORA EM TRANSPORTES.

ORIENTADOR: Prof. DR. JOSÉ LeOMAR FERNANDES JÚNIOR 
Ficha catalografica preparada pela Seção de Tratamento da Informação do Serviço de Biblioteca - EESC/USP

B546a

Bertollo, Sandra A. Margarido

Avaliação laboratorial de misturas asfálticas densas modificadas com borracha reciclada de pneus / Sandra A. Margarido Bertollo. -- São Carlos, 2002.

Tese (Doutorado) -- Escola de Engenharia de São CarlosUniversidade de São Paulo, 2002.

Área: Transportes.

Orientador: Prof. Dr. José Leomar Fernandes Júnior.

1. Misturas asfálticas. 2. Borracha de pneu.

3. Processo seco. I. Titulo. 


\section{FOLHA DE JULGAMENTO}

Candidata: Engenheira SANDRA APARECIDA MARGARIDO BERTOLLO

Tese defendida e julgada em 30-08-2002 perante a Comissão Julgadora:

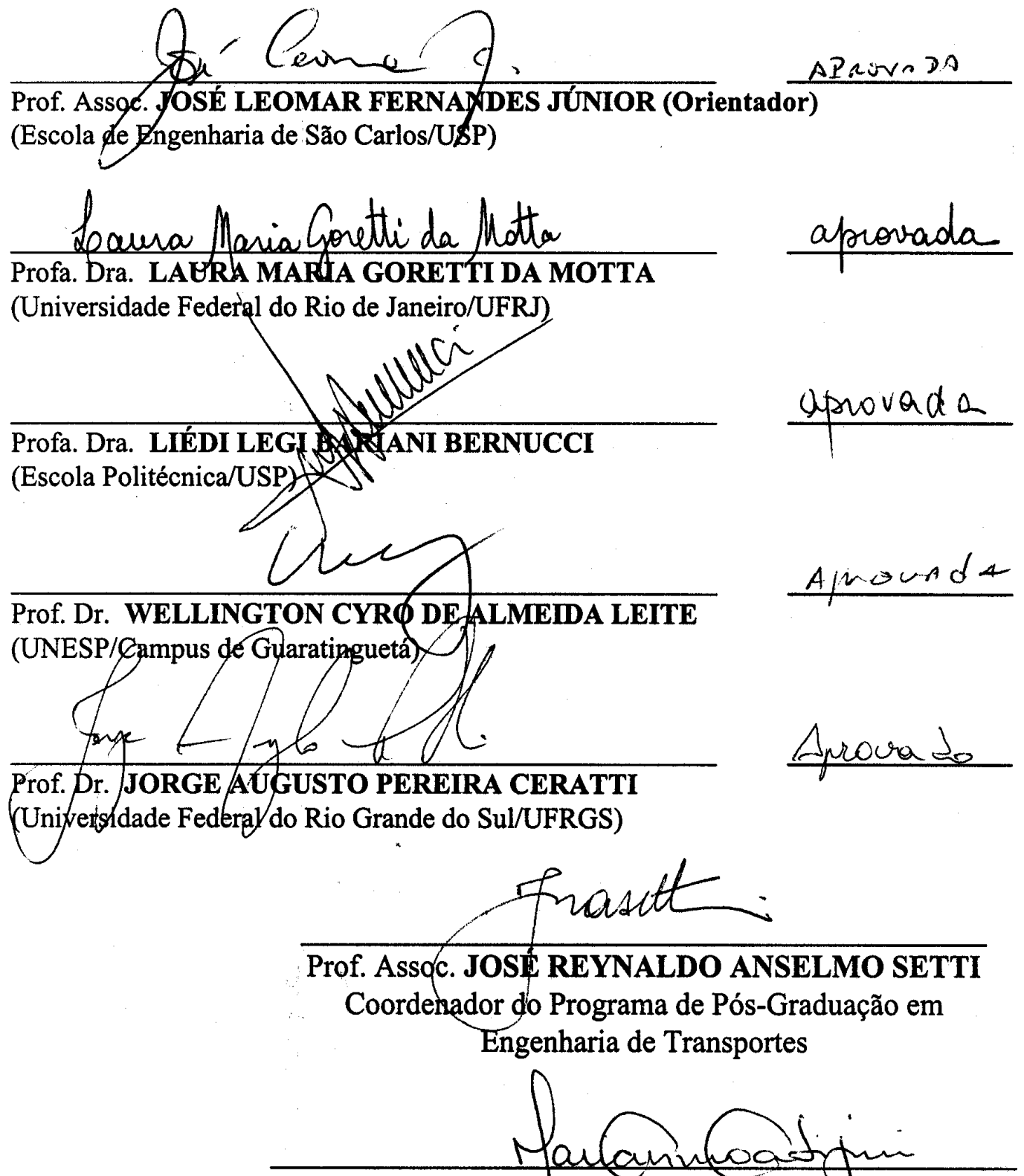

Profa. Assoc. MARIA DO CARMO CALIJURI

Presidente da Comissão de Pós-Graduação da EESC 


\section{Dedicatória}

Ao meu marido, Julio Cesar Bertollo e

aos meus pais, Narciso e Isaura 


\section{Agradecimentos}

Ao Prof. Dr. José Leomar Fernandes Júnior, pela escolha do tema da orientação que muito contribuiu para o meu aprendizado, pela forma como conduziu o trabalho e pela confiança, paciência e atenção dispensadas a mim;

À Fundação de Amparo à Pesquisa do Estado de São Paulo - FAPESP, pela bolsa de estudo concedida;

Ao meu marido Julio Cesar Bertollo, pelo carinho, pela paciência e pelo apoio nos momentos mais difíceis;

Ao Laboratório de Tecnologia de Pavimentação do Departamento de Transportes da Escola Politécnica da USP, particularmente à Profa. Dra. Liedi B. Bernucci, sempre muito gentil e atenciosa, pela confiança, incentivo e sugestões e ao amigo Edson de Moura pela boa vontade, carinho, respeito e atenção;

À Profa. Dra. Nair Cristina Margarido Brondino, prima e amiga, pela enorme paciência, pelo incentivo, sugestões e auxílio com o tratamento estatístico dos resultados;

À minha irmã Paula e meu cunhado Bruno, pela hospedagem durante o longo estágio em São Paulo e pela importante ajuda com o analisador de imagens e na interpretação dos resultados dos ensaios de porosimetria;

À Eng. MSc. Simonne Amaral, amiga sempre disposta a ajudar, pelas palavras de incentivo e apoio; 
À Borcol Indústria de Borracha Ltda., pelo fornecimento da borracha de pneus triturada, à Ipiranga Asfaltos S. A., pelo fornecimento do ligante asfáltico e à Pedreira INDERP, pelo fornecimento dos agregados pétreos;

Ao Instituto de Pesquisas Tecnológicas (IPT) pela realização dos ensaios de caracterização do ligante asfáltico, em especial ao Eng. Rubens Vieira;

Ao Laboratório de Caracterização Tecnológica do Departamento de Engenharia de Minas da Escola Politécnica da USP, pela utilização do microscópio óptico e analisador de imagens;

Ao Laboratório de Saneamento do Departamento de Hidráulica e Saneamento da Escola de Engenharia de São Carlos, USP, particularmente ao Prof. Dr. Valdir Schalch e ao técnico Julio Cesar Trofino pela realização dos ensaios de solubilização e lixiviação;

Ao Prof. Dr. Glauco Túlio Pessa Fabbri, do Departamento de Transportes da Escola de Engenharia de São Carlos, pelas sugestões;

Aos técnicos do Laboratório de Estradas do Departamento de Transportes da EESC/USP, Antonio C. Gigante, Antonio C. de Oliveira e Roberto A. Morasco, pela colaboração na execução dos ensaios exploratórios;

Ao Eng. MSc. Marcelo C. Almeida, do Departamento de Engenharia de Materiais da UFSCar, pela amizade e pela valiosa contribuição;

Aos funcionários do Departamento de Transportes da Escola de Engenharia de São Carlos da USP, em especial à Heloisa H. M. Belo, Lílian Pereira Rossi, Antonia Magaly B. M. Cesar, Elisabeth Z. Ortega e Sueli L. Chinaglia, pessoas sempre gentis;

A todos os amigos com quem tenho convivido durante esses anos, em especial à Sandra Fabiana Rodgher e à Andrea Arantes Severi. 


\section{SUMÁRIO}

LISTA DE FIGURAS.................................................................. viii

LISTA DE TABELAS .................................................................. xi

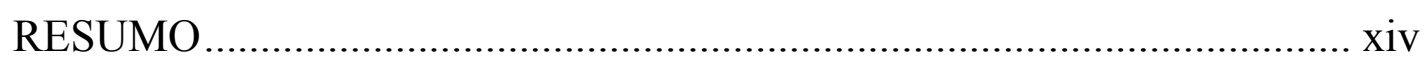

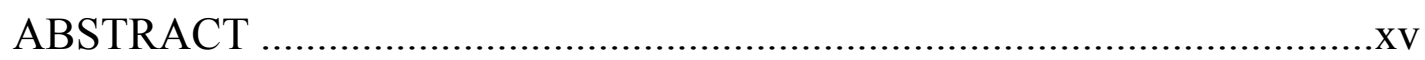

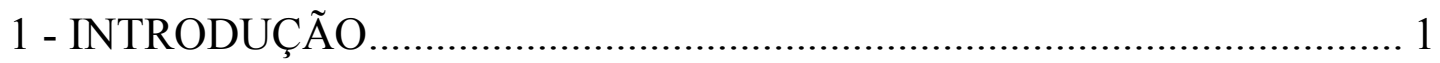

2- O PROBLEMA DOS PNEUS INSERVÍVEIS ...................................... 7

2.1 - Pneu: Composição e Características......................................................... 7

2.2 - O Descarte dos Pneus ..................................................................... 10

2.3 - Disponibilidade de Pneus Usados .................................................... 13

2.4 - Redução, Reutilização e Reciclagem dos Pneus Usados ....................... 20

2.5 - Gestão de Resíduos e Legislação ....................................................... 31

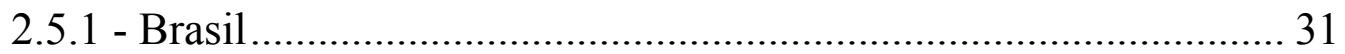

2.5.1.1 - Algumas Considerações sobre a Importação de Pneus Usados ....................................................... 37

2.5.1.2 - Destinação Final dos Pneus no Brasil: Proposta dos Importadores e Fabricantes ................................. 41

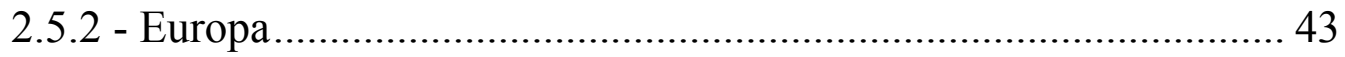

2.5.3 - Estados Unidos ............................................................... 46 


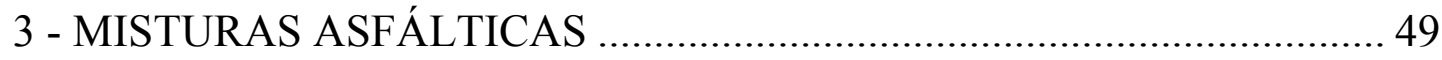

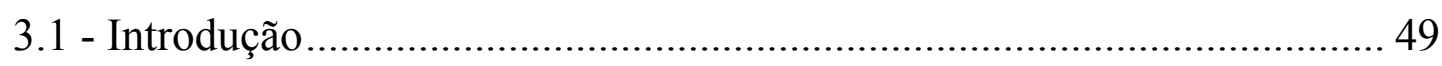

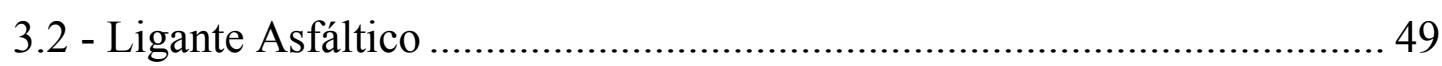

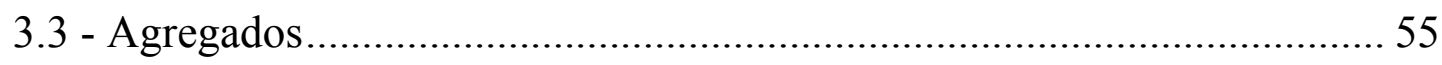

3.4 - Dosagem das Misturas Asfálticas.......................................................... 58

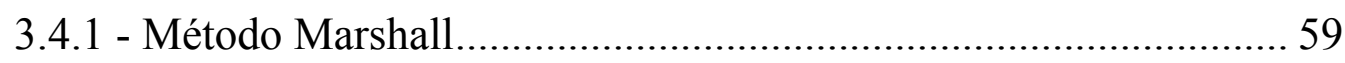

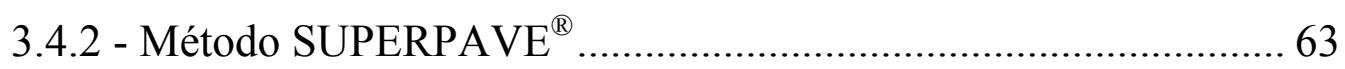

3.5 - Principais Defeitos de Misturas Asfálticas Densas .................................. 72

3.5.1 - Deformação Permanente.............................................................. 73

3.5.2 - Trincamento por Fadiga............................................................. 75

3.5.3 - Trincamento a Baixa Temperatura …………………………........ 77

3.6 - Principais Propriedades dos Agregados Pétreos ..................................... 78

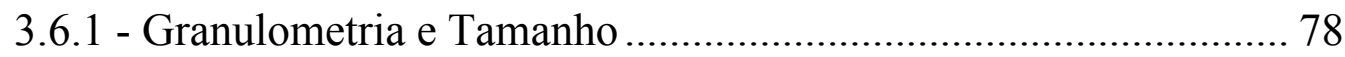

3.6.2 - Formato da Partícula, Angularidade e Textura Superficial......... 79

3.6.3 - Presença de Materiais Deletérios................................................. 80

3.6.4 - Resistência à Abrasão e Fragmentação ........................................ 80

3.6.5 - Durabilidade e Sanidade ......................................................... 81

3.6.6 - Atrito e Resistência ao Polimento ................................................ 82

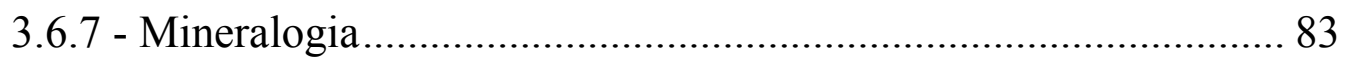

3.6 .8 - Propriedades Químicas ............................................................ 84

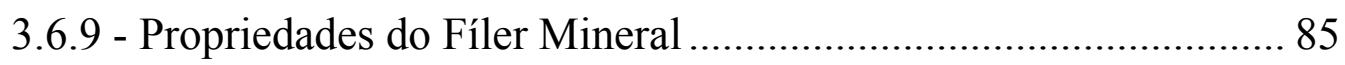

4 - UTILIZAÇÃO DE BORRACHA DE PNEUS EM PAVIMENTAÇÃO

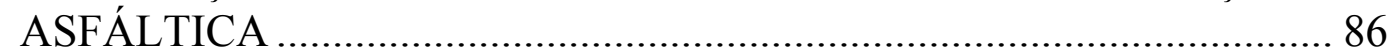

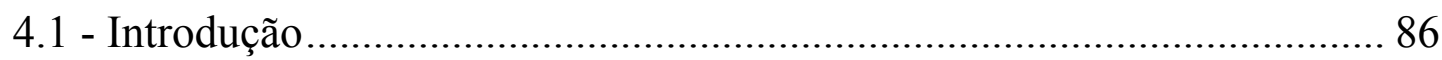

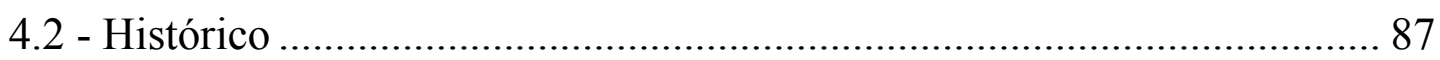

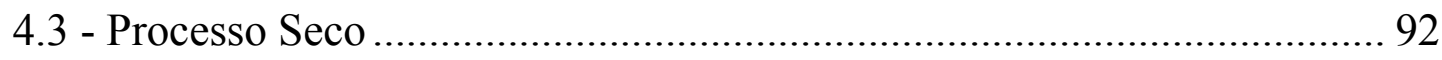

4.3.1 - Considerações sobre a Dosagem ................................................ 96

4.3.2 - Comportamento ao Envelhecimento ......................................... 99

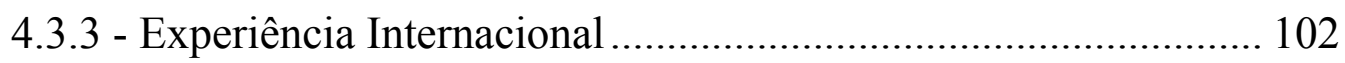

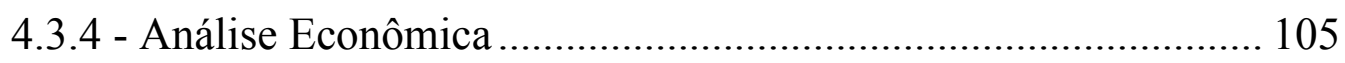




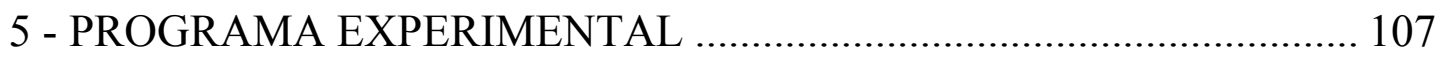

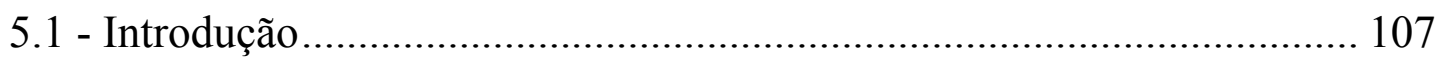

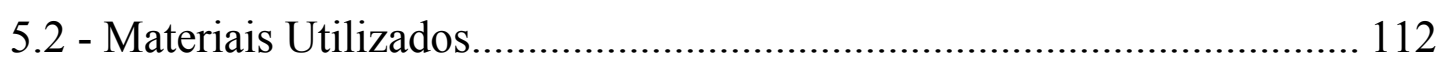

3.2.1 - Borracha de Pneu..................................................................... 112

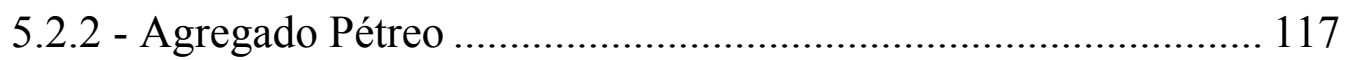

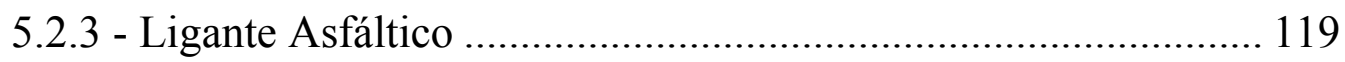

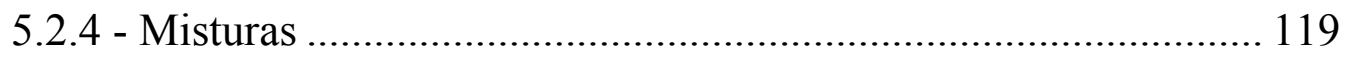

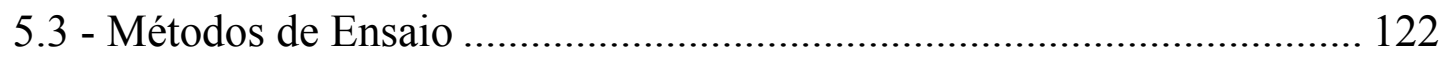

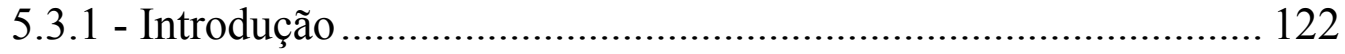

5.3.2 - Solubilização e Lixiviação........................................................ 123

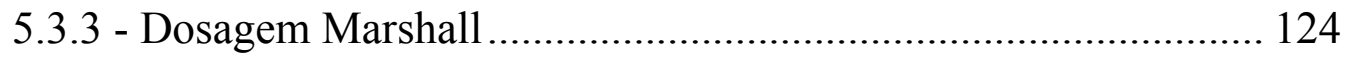

5.3.3.1 - Preparação dos Materiais e Moldagem dos Corpos-

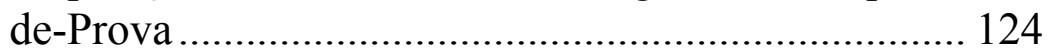

5.3.3.2 - Estabilidade e Fluência Marshall ................................ 128

5.3.4 - Determinação do Módulo de Resiliência .................................. 129

5.3.5 - Determinação da Resistência à Tração ………………………..... 132

5.3.6 - Deformação Permanente em Simulador de Tráfego .................. 133

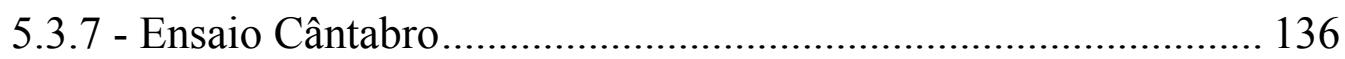

5.3.8 - Resistência de Misturas Betuminosas Compactadas a Danos por Umidade Induzida ............................................................ 137

6 - APRESENTAÇÃO E ANÁLISE DOS RESULTADOS ……………....... 140

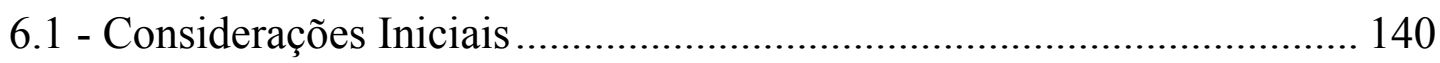

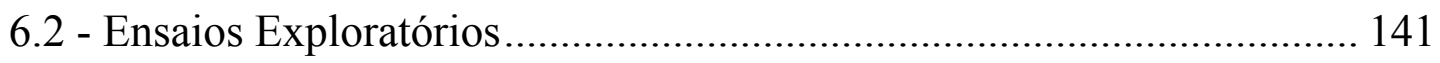

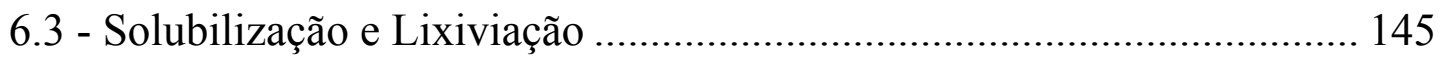

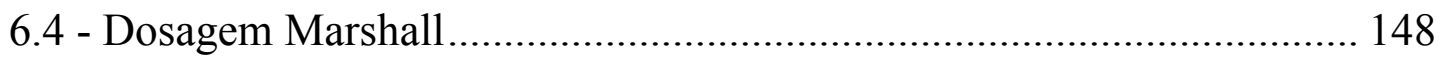

6.4.1 - Efeito do Envelhecimento nas Propriedades Volumétricas ...... 148

6.4.2 - Estabilidade e Fluência Marshall................................................ 152

6.5 - Módulo de Resiliência e Resistência à Tração ……………………….... 153

6.6 - Deformação Permanente em Equipamento Simulador de Tráfego ....... 161

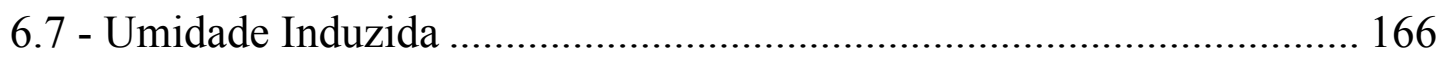

6.8 - Perda de Massa no Ensaio Cântabro ......................................................... 168 
6.9 - Experimento Fatorial: Análise Estatística ....................................... 171

6.9.1 - Cálculo das Variâncias ......................................................... 172

6.9.2 - Testes de Significância ........................................................ 174

6.9.3 - Construção dos Modelos Matemáticos.................................. 175

6.9.4 - Análise dos Resultados ...................................................... 181

7 - CONCLUSÕES E SUGESTÕES PARA TRABALHOS FUTUROS .... 184

REFERÊNCIAS BIBLIOGRÁFICAS ................................................. 191

APÊNDICE 1 - Resolução nº 258 do CONAMA

APÊNDICE 2 - Resultados dos Ensaios de Caracterização da Borracha: Porosimetria e Análise Termogravimétrica

APÊNDICE 3 - Resultados dos Ensaios de Trilha de Roda em Equipamento Simulador de Tráfego tipo LCPC 


\section{Lista de Figuras}

Figura $\mathrm{n}^{\mathrm{o}}$

Página

1 - Pneus acumulados no canteiro central da Marginal Tietê (reprodução da foto que ilustra a reportagem "Rio Tietê transforma-se em depósito de pneus", publicada no jornal O Estado de São Paulo - PAIVA, 1998)......... 2

2 - Pneu de construção radial.......................................................................... 7

3 - Pneu diagonal e radial (adaptada de PIRELLI, 1998)................................. 8

4 - Lixo acumulado nas margens do rio Tietê (PAIVA, 1999) .......................... 11

5 - Municípios onde foram feitos os levantamentos de quantidade e formas de disposição dos pneus inservíveis ........................................................ 13

6 - Questionário para obtenção das informações referentes à disposição

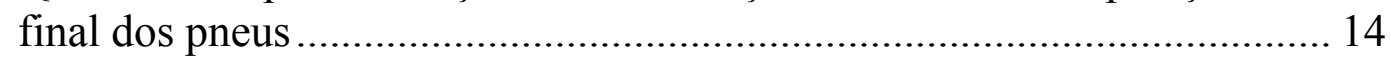

7 - Destino dos pneus usados na União Européia em 2000 (UTWG, 2001)... 22

8 - Destino das carcaças de pneus na Austrália (ENVIRONMENT

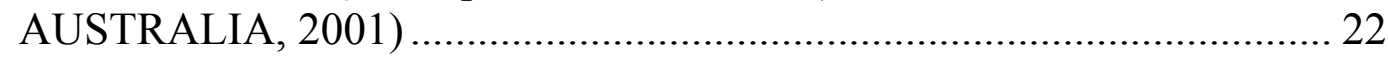

9 - Erosão em área rural do município de Piracicaba-SP .................................. 24

10 - Exemplos de utilização de pneus no escoamento de água pluvial ........... 25

11 - Experiência internacional de reutilização de pneus na construção de bueiros (TRANSAFETY, 1997) ............................................................ 26

12 - Trechos de pavimentos modificados com adição de borracha de pneus na cidade de Santos-SP (BERTOLLO et al., 2000) ................................. 31

13 - Pneus armazenados em galpões da Prefeitura de Sorocaba-SP (fotos

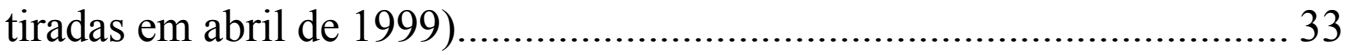

14 - Incêndio de 6 a 8 milhões de pneus ocorrido na Califórnia, EUA, em 1999 (CARLSON \& ZHU, 1999)....................................................... 34

15 - Especificação SUPERPAVE ${ }^{\circledR}$ para mistura com agregado de tamanho

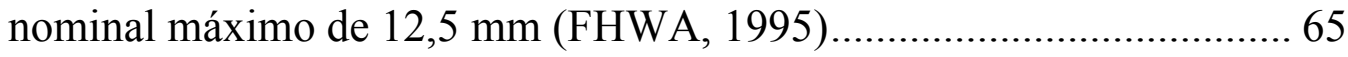

16 - Processo seco de incorporação de borracha em misturas asfálticas......... 87

17 - Programação da investigação laboratorial................................................ 108

18 - Diagrama de blocos do método de trabalho experimental ....................... 111

19 - Partículas de borracha na granulometria G (fração: \#8 - \#16) ................ 113

20 - Partículas de borracha na granulometria G (fração: \#16 - \#30) .............. 113

21 - Partículas de borracha na granulometria F (fração: \#30 - \#50)............... 114 
22 - Partículas de borracha na granulometria F (fração: \#50 - \#100)............ 114

23 - Porosidade em mercúrio para três frações de borracha ......................... 116

24 - Curva granulométrica da mistura estudada ........................................ 118

25 - Frações granulométricas onde foram incorporadas as amostras de borracha $\mathrm{G}$ e $\mathrm{F}$

26 - Determinação da densidade aparente considerando amostras na condição de amostra saturada seca superficialmente (AASHTO T-166)

27 - Dispositivos de leitura para determinação da estabilidade e fluência.... 128

28 - Equipamento utilizado na determinação do módulo de resiliência do LTP/EPUSP

29 - Dispositivo LVDT utilizado para medir as deformações sofridas pelo corpo-de-prova

30 - Detalhe do equipamento utilizado na realização do ensaio de resistência à tração por compressão diametral

31 - Misturadora utilizada na usinagem das misturas asfálticas no LTP/EPUSP

32 - Moldagem das placas para o ensaio de trilha de roda

33 - Equipamento simulador de tráfego em laboratório tipo LCPC, instalado no LTP/EPUSP.

34 - Ensaio para a determinação da resistência de misturas betuminosas compactadas a danos por umidade induzida (AASHTO T-283) .

35 - Equipamentos utilizados na saturação a vácuo dos corpos-de-prova: dessecador e bomba de vácuo

36 - Efeito do envelhecimento (tempo de digestão) para as misturas com borracha.

37 - Efeito do envelhecimento para a mistura de controle.

38 - Diferenças entre as médias de MR e RT para misturas virgens e envelhecidas (método de Tukey)

39 - Diferenças entre as médias de MR e RT (método de Tukey)

40 - Influência do teor de ligante no afundamento em trilha de roda.

41 - Influência da granulometria da borracha ( $\mathrm{G} \times \mathrm{F})$ no afundamento em trilha de roda

42 - Influência da quantidade da borracha no afundamento em trilha de roda

43 - Resultados do ensaio Cântabro 168

44 - Diferenças entre as médias de perda de massa (método de Tukey) 
45 - Resíduo versus resposta estimada para MR …………………………... 178

46 - MR: resíduo versus variável independente T (teor de borracha) ........... 179

47 - MR: resíduo versus variável independente G (granulometria da

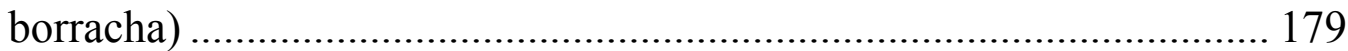

48 - Resíduo versus resposta estimada para RT …………………………..... 179

49 - RT: resíduo versus variável independente T (teor de borracha) ............. 180

50 - Resíduo versus resposta estimada para deformação permanente

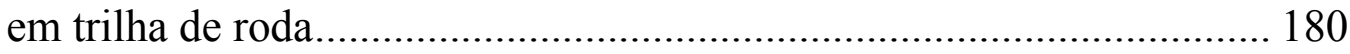

51 - Deformação permanente: resíduo versus variável independente T

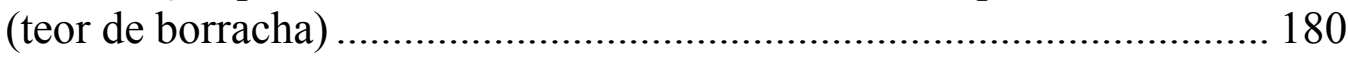

52 - Deformação permanente: resíduo versus variável independente $G$

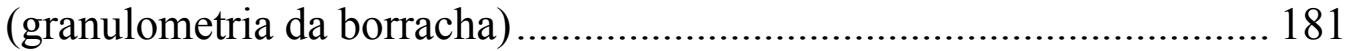

53 - Efeito do teor e granulometria da borracha no módulo de resiliência ... 182

54 - Efeito do teor e granulometria da borracha na resistência à tração......... 182

55 - Efeito do teor e granulometria da borracha no afundamento em trilha de roda 


\section{Lista de Tabelas}

Tabela $\mathrm{n}^{\mathrm{o}}$

Página

1 - Distribuição percentual dos recipientes existentes e positivos para larvas de Aedes aegypti, para o estado de São Paulo

2 - Levantamento da quantidade de pneus descartados e estocados em algumas cidades do estado de São Paulo.

3 - Geração anual de pneus nos países da Comunidade Européia (adaptado de UTWG, 2001)

4 - Frota de veículos automotores em 1999 no estado de São Paulo e no Brasil (GEIPOT, 2001a) e população de acordo com o Censo Demográfico 2000 (IBGE, 2001).

5 - Destinação das carcaças de pneus nos Estados Unidos em 1996 (EPA, 1999) e 2000 (RMA, 2000)

6 - Extensão total das rodovias pavimentadas em 1995 e 1999 (GEIPOT, 2001b) e estimativa de consumo de pneus

7 - Extensão total das rodovias pavimentadas e não-pavimentadas em 1999, separadas por região (GEIPOT, 2001b)

8 - Prazos e quantidades de pneus a serem coletados de acordo com a resolução № 258 do Conselho Nacional do Meio Ambiente

9 - Importação de pneumáticos usados e recauchutados entre 1995 e 1999 (TOMMASINI, 2000)

10 - Panorama da disposição de pneus usados nos Estados Unidos (RMA, 2000)

11 - Critérios da especificação SUPERPAVE ${ }^{\circledR}$ para as propriedades de consenso (adaptada de SHRP, 1999)

12 - Valores para estabilidade (E) e fluência (F) estabelecidos pelo DER-SP (1991)

13 - Valores para estabilidade (E) e fluência (F) estabelecidos pelo DNER (1997) e ABNT (1993)

14 - Critérios estabelecidos pelo DER-SP (1991), DNER (1997) e ABNT (1993) para volume de vazios (Vv) e relação betume vazios (RBV)

15 - Especificação SUPERPAVE ${ }^{\circledR}$ para determinação do número de revoluções (adaptada de SHRP, 1999)

16 - Especificação SUPERPAVE ${ }^{\circledR}$ para projeto volumétrico de misturas (adaptada de SHRP, 1999).

17 - Especificação SUPERPAVE ${ }^{\circledR}$ para VAM (adaptada de SHRP, 1999).... 70 
18 - Fatores que influem nas deformações permanentes de concreto asfáltico (SOUZA et al., 1991 apud COELHO, 1996)....

19 - Algumas das tecnologias de incorporação de borracha de pneus em misturas asfálticas (adaptada de EPPS, 1994)

20 - Especificações recomendadas para misturas modificadas com borracha, para diferentes níveis de tráfego (adaptada de EATON et al., 1991)

21 - Especificação PlusRide ${ }^{\circledR}$ para a borracha (FHWA, 1993) ......................... 94

22 - Fatores e níveis considerados no experimento ....................................... 110

23 - Propriedades físicas da borracha fornecida pela BORCOL .................... 112

24 - Características da borracha utilizada...................................................... 115

25 - Características dos agregados pétreos utilizados .................................... 117

26 - Propriedades do CAP-20 utilizado no preparo das misturas.................... 119

27 - Composição granulométrica dos corpos-de-prova................................... 121

28 - Resultados do ensaio de lixiviação........................................................ 146

29 - Resultados do ensaio de solubilização ................................................. 147

30 - Efeito do tempo de envelhecimento nas propriedades volumétricas ..... 149

31 - Resultados dos ensaios Marshall ........................................................ 152

32 - Efeito do tempo de envelhecimento nos valores de MR e RT ................ 154

33 - Análise de variância para MR de amostras virgens e envelhecidas....... 154

34 - Análise de variância para RT de amostras virgens e envelhecidas ........ 155

35 - Resultados de MR, RT e relação MR/RT ………………………….... 158

36 - Quadro da análise de variância para MR .............................................. 158

37 - Quadro da análise de variância para RT.............................................. 159

38 - Comparação entre médias pelo método de Tukey, considerando-se

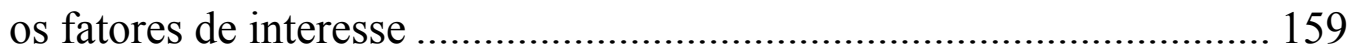

39 - Resultados obtidos no ensaio de deformação permanente em

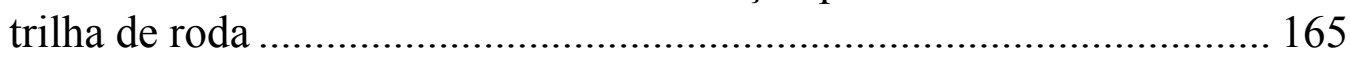

40 - Resultado do ensaio de umidade induzida para a mistura de controle... 167

41 - Análise de variância para perda de massa no ensaio Cântabro ............... 169

42 - Comparação entre médias de perda de massa (ensaio Cântabro) pelo método de Tukey, considerando-se os fatores de interesse ........... 170

43 - Matriz de planejamento com efeitos de interação ..................................... 171

44 - Quadro de análise de variância (ANOVA) para um experimento com 2 fatores 
45 - Experimento fatorial: análise de variância para MR ........................... 174

46 - Experimento fatorial: análise de variância para RT ............................ 175

47 - Experimento Fatorial: análise de variância para afundamento em trilha de roda. 


\section{Resumo}

Este trabalho apresenta os resultados de um estudo laboratorial que teve por objetivo avaliar o efeito produzido pelo teor e granulometria da borracha reciclada de pneumáticos sobre as propriedades de uma mistura asfáltica densa. Foram preparadas misturas asfálticas com duas granulometrias de borracha, substituindo parte dos agregados pétreos em algumas frações da curva granulométrica ("processo seco"). Essas misturas foram comparadas a uma mistura de controle, sem borracha. Para avaliação das propriedades mecânicas, as misturas foram submetidas ao ensaio de compressão diametral dinâmico para determinação do módulo de resiliência, ao ensaio de resistência à tração por compressão diametral e ao ensaio de afundamento em trilha de roda em equipamento simulador de tráfego em laboratório. Os resultados mostram que a adição de partículas mais finas propicia a melhoria no desempenho quanto à deformação permanente. As misturas modificadas com borracha apresentaram menores valores de módulo de resiliência e de resistência à tração quando comparadas à mistura de controle. Os resultados dos ensaios mostram que o tamanho e o teor de borracha influem nas propriedades da mistura: quanto maior o teor e o tamanho de borracha, menor o módulo de resiliência; quanto maior o teor de borracha, menor a resistência à tração. A granulometria da borracha não influenciou nos resultados de resistência à tração. A adição de borracha de pneus em obras de pavimentação asfáltica pode contribuir para a minimização dos problemas relacionados à disposição final dos pneus inservíveis e, ao mesmo tempo, melhorar algumas propriedades de engenharia das misturas asfálticas.

Palavras-chave: misturas asfálticas, borracha de pneu, processo seco. 


\section{Abstract}

This work presents the findings of a laboratory study that aimed to evaluate the effects of recycled tire rubber content and gradation on the properties of dense asphalt mixtures. It was considered two ranges of rubber particle sizes, which substituted part of mineral aggregates in the mixture gradation. The rubber modified asphalt mixtures ("dry process") were compared to a control mixture without rubber. For the evaluation of mechanical properties, the asphalt mixtures were submitted to three laboratory tests: dynamic indirect tension for the determination of the resilient modulus; tensile strength under indirect tension; and resistance to rutting in a wheel-tracking device. The results show that smaller rubber particles increase the resistance to rutting. The rubber modified asphalt mixtures presented smaller values of resilient modulus and tensile strength than the control mixture. The tests results showed that the size and percentage of rubber affected the mixture properties: the higher the rubber size and the rubber content, the smaller the resilient modulus; the higher the rubber content, the smaller the tensile strength. The rubber gradation had no influence on the tensile strength values. The use of tire rubber in the asphalt paving industry can contribute to minimize the problems related to the disposal of used tires and, at the same time, improve some engineering properties of asphalt mixtures.

$\underline{\text { Key words: }}$ asphalt mixtures, tire rubber, dry process 


\section{1 - INTRODUÇÃO}

Embora seja significativo o crescimento da frota de veículos no Brasil, a magnitude do efeito ambiental causado pelos milhões de pneus inservíveis gerados a cada ano não se percebe tão facilmente. A disposição final dos pneus representa um problema de difícil solução, pois são objetos volumosos que precisam ser armazenados em condições apropriadas para evitar riscos de incêndio e proliferação de insetos e roedores. A disposição em aterros sanitários se torna inviável, pois os pneus inteiros apresentam baixa compressibilidade e degradação muito lenta.

No Brasil não existe monitoração por parte do Governo nem por parte do setor privado sobre a disposição final dos pneus usados, assim como não há levantamento dos depósitos de pneus abandonados em todo o país. A estimativa de geração de resíduos de pneus está baseada na frota de veículos e na produção anual de pneus novos.

Segundo a Associação Brasileira da Indústria de Pneumáticos, a produção brasileira de pneus em 1999 foi de cerca de 43,4 milhões de unidades. O mercado interno absorveu cerca de 28,2 milhões. Desse montante, 8,1 milhões foram destinados à indústria automobilística e 20,1 milhões ao mercado de reposição (TOMMASINI, 2000). Em 1999, o Brasil contava como uma frota de 33.799.523 de veículos automotores (GEIPOT, 2001a). 
A ausência de dados sobre o destino de pneus inservíveis no Brasil não permite determinar com certeza o passivo ambiental. Algumas estimativas indicam que existem mais de 100 milhões de pneus abandonados em todo o país (SATO, 1999).

Considerando a dificuldade para a disposição das carcaças de pneus em aterros sanitários e a falta de uma ação governamental para fiscalização da destinação adequada desses resíduos, há uma tendência da população em abandonar os pneus em cursos de água, terrenos baldios e beiras de estradas. Um exemplo da disposição ilegal dos pneus vem ocorrendo na cidade de São Paulo, onde o rio Tietê é utilizado como depósito de pneus (Figura 1). Segundo reportagem publicada no jornal O Estado de São Paulo (PAIVA, 1998), em apenas dois meses de dragagem foram retirados cerca de 2.500 pneus do rio Tietê. Este fato vem sendo constantemente denunciado nos principais jornais do Estado de São Paulo (SILVA, 1997; PAIVA, 1998 e 1999).

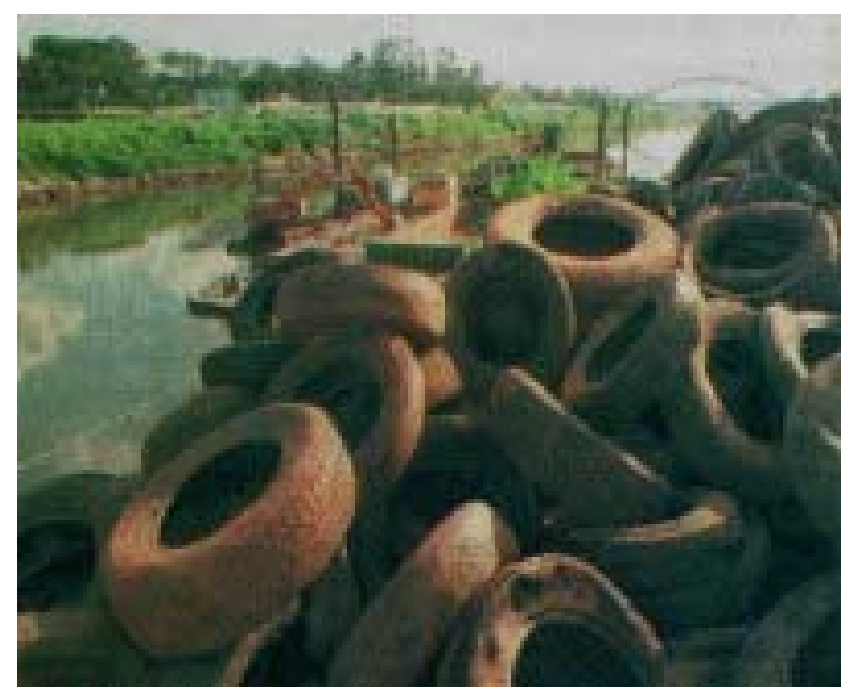

FIGURA 1 - Pneus acumulados no canteiro central da Marginal Tietê (reprodução da foto que ilustra a reportagem "Rio Tietê transforma-se em depósito de pneus", publicada no jornal $O$ Estado de São Paulo - PAIVA, 1998). 
Alternativas devem ser analisadas no sentido de equacionar a questão desses resíduos no país. A Resolução $\mathrm{n}^{\mathrm{o}} 258$ do Conselho Nacional do Meio Ambiente - CONAMA, publicada no Diário Oficial de 02 de dezembro de 1999, determina que, a partir de $1^{0}$ de janeiro de 2002 , as empresas fabricantes e as importadoras de pneumáticos ficam obrigadas a coletar e dar destinação final, ambientalmente adequada, aos pneus inservíveis existentes no território nacional, na proporção relativa às quantidades fabricadas e/ou importadas.

Nos Estados Unidos, país que mais produz pneus inservíveis no mundo (mais de um pneu por habitante por ano), existem leis que regulamentam a aquisição, armazenagem e processamento de pneus, impõem restrições para disposição em aterros sanitários e oferecem incentivos para o desenvolvimento de novas alternativas de uso, como por exemplo, a incorporação em misturas asfálticas (FHWA, 1993; EPA, 1999).

A análise da utilização de borracha de pneus triturada nas misturas asfálticas deve considerar os benefícios em termos ambientais e de engenharia. Enquanto é indiscutível o benefício da reciclagem para esse tipo de resíduo, não existe consenso se a utilização de borracha triturada traz benefícios significativos às propriedades de engenharia, com a obtenção de um pavimento com melhor desempenho em longo prazo, superando os pavimentos tradicionais.

Dentre os potenciais benefícios que a incorporação de borracha de pneus usados pode acarretar às misturas asfálticas, destacam-se: aumento da flexibilidade a baixas temperaturas, aumento da resistência à deformação permanente a altas temperaturas, aumento da resistência à fadiga, maior resistência ao desgaste e ao envelhecimento (FHWA, 1993). Esses revestimentos também podem apresentar uma significativa melhoria das 
condições de circulação (diminuição dos riscos de derrapagem em pista molhada) e a diminuição do ruído de contato entre o pneu e o pavimento (resposta a outro problema de meio ambiente, a poluição sonora) - BALLIÉ \& ROFFÉ (2000).

Existem dois métodos de incorporação dos pneus nas misturas asfálticas. No processo úmido são adicionadas partículas finas de borracha ao cimento asfáltico, produzindo um novo tipo de ligante denominado asfalto-borracha. No processo seco, objeto deste estudo, as partículas de borracha substituem parte dos agregados pétreos na mistura. Após a adição do ligante, formam um produto denominado concreto asfáltico modificado com adição de borracha.

Este trabalho tem por objetivo verificar a possibilidade de se utilizar borracha triturada em misturas asfálticas (processo seco), obtendo-se um material com propriedades que permitam seu uso em engenharia. Procurou-se analisar as alterações no comportamento mecânico de uma mistura asfáltica convencional quando parte de seus agregados é substituída por borracha reciclada. Foram considerados os fatores teor e granulometria de borracha e, para algumas misturas, procurou-se também analisar a influência do teor de ligante asfáltico adicionado e do tempo de digestão (envelhecimento de curto prazo).

Busca-se, dessa forma, contribuir para o equacionamento do grave problema ambiental que é a disposição de resíduos sólidos, pois a reutilização de pneus em larga escala no Brasil vai depender do conhecimento profundo dos aspectos econômicos e técnicos, relacionados ao meio ambiente e ao desempenho como material de construção. 
Este trabalho foi organizado em sete capítulos. Inicialmente faz-se uma breve discussão a respeito do tema abordado, mostrando sua abrangência, importância e os objetivos pretendidos. O capítulo 2 apresenta um levantamento bibliográfico compreendendo os problemas decorrentes da disposição ilegal de pneus inservíveis, a legislação pertinente, as possibilidades de redução da geração, reutilização e reciclagem de pneus, destacando sua utilização em pavimentação asfáltica. Apresentam-se as informações obtidas de um levantamento da quantidade e formas de disposição das carcaças de pneus em algumas cidades do estado de São Paulo.

O capítulo 3 apresenta a revisão bibliográfica dos principais conceitos envolvendo as misturas asfálticas utilizadas em pavimentação, incluindo os materiais que as constituem, os ensaios para caracterização desses materiais, o projeto de mistura em laboratório (métodos Marshall e SUPERPAVE ${ }^{\circledR}$ ) e seu comportamento mecânico em serviço.

O capítulo 4 refere-se à revisão bibliográfica sobre a utilização de borracha de pneus em pavimentação asfáltica. São apresentados os métodos de incorporação de borracha de pneus nas misturas asfálticas, com destaque especial para o processo seco, incluindo algumas considerações sobre a dosagem e o comportamento mecânico das misturas modificadas.

O capítulo 5 aborda o programa experimental desenvolvido. Encontram-se a procedência e caracterização dos materiais utilizados nas misturas estudadas, bem como a descrição sucinta de todos ensaios laboratoriais realizados neste estudo: solubilização e lixiviação de resíduos, estabilidade e fluência Marshall, compressão diametral cíclica por cargas repetidas (módulo de resiliência), resistência à tração por compressão diametral, deformação permanente em trilha de roda, umidade induzida e perda de massa no ensaio Cântabro. 
O capítulo 6 é dedicado à apresentação e análise dos resultados dos ensaios laboratoriais. Procurou-se analisar a influência da quantidade e do tamanho das partículas de borracha nas propriedades mecânicas das misturas asfálticas.

No capítulo 7 são tecidas as considerações finais sobre a gestão de resíduos e a avaliação laboratorial de misturas asfálticas modificadas com borracha, apresentadas as conclusões e sugestões para trabalhos futuros. 


\section{2 - O Problema dos PNeus InSERVíVeis}

\section{1 - Pneu: CoMposição e CARACTERÍSTICAS}

O pneu apresenta uma estrutura complexa, formada por diversos materiais que visam conferir as características necessárias ao seu desempenho e segurança. A Figura 2 apresenta as principais partes que compõem um pneu: carcaça, banda de rodagem, talões e flancos. Cabe ressaltar que estes componentes apresentam diferentes composições químicas e propriedades mecânicas.

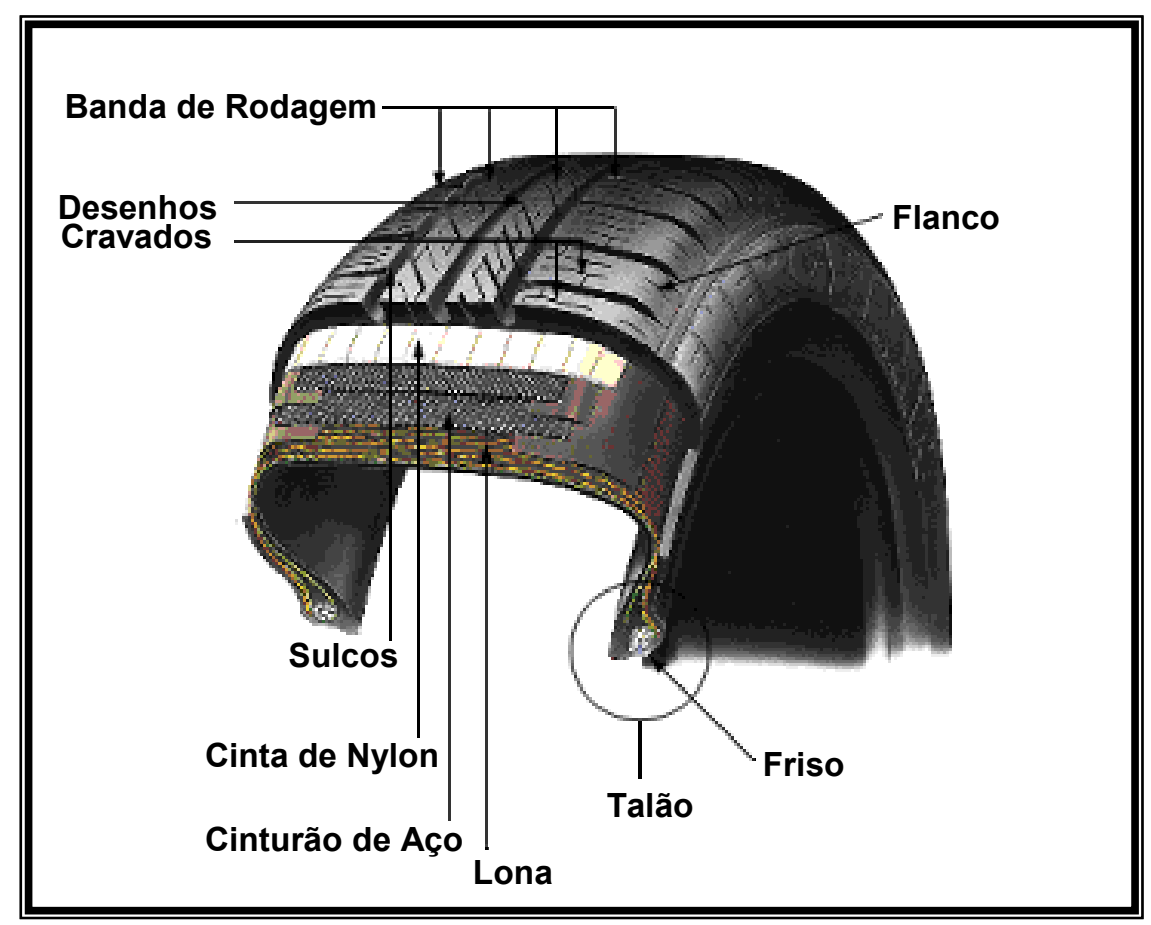

FIGURA 2 - Pneu de construção radial. 
A carcaça é a parte resistente do pneu, constituída de lonas de poliéster, náilon ou aço. Tem como função reter o ar sob pressão que suporta o peso total do veículo. Nos pneus radiais as cinturas complementam sua resistência.

Os talões são constituídos internamente de arames de aço de grande resistência e têm por finalidade manter o pneu acoplado ao aro. A banda de rodagem é a parte do pneu que entra diretamente em contato com o solo, sendo formada por um composto especial de borracha que oferece grande resistência ao desgaste. Seus desenhos, constituídos por partes cheias e vazias (sulcos), oferecem desempenho e segurança ao veículo. Os flancos protegem a carcaça de lonas e são dotados de uma mistura especial de borracha com alto grau de flexibilidade.

Os pneus podem apresentar construção radial ou convencional (Figura 3). Nos pneus de construção convencional, as lonas se estendem de talão a talão, formando ângulo ("diagonal") com a linha central da banda de rodagem. As lonas subseqüentes se cruzam em ângulos opostos. Já nos pneus de construção radial, a lona se estende de talão a talão, no sentido radial, formando um ângulo reto em relação à linha central da banda de rodagem. Outra característica deste tipo de construção é o cinturão de aço que circunda o pneu, logo abaixo da banda de rodagem.

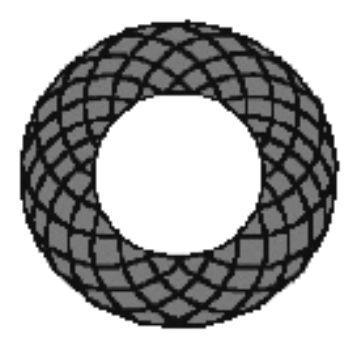

(a) Pneu Diagonal (Convencional)

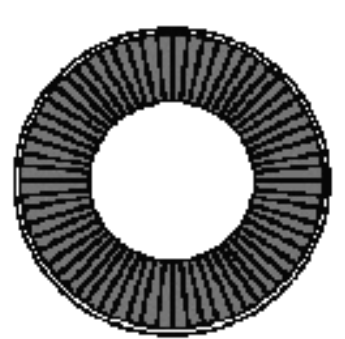

(b) Pneu Radial

FIGURA 3 - Pneu diagonal e radial (adaptada de PIRELLI, 1998). 
A construção radial proporciona ao pneu maior flexibilidade e resistência. Estas características se refletem em maior durabilidade, melhor aderência, maior eficiência na aceleração e desaceleração, o que proporciona economia de combustível e um melhor comportamento na estrada.

Os ingredientes básicos necessários à fabricação dos pneus são (TNRCC, 1999):

- Arames e malhas de aço;

- Lonas de náilon ou poliéster;

- Borracha natural e sintética (SBR - copolímero de estireno e butadieno);

- Substâncias químicas de reforço: negro-de-fumo, sílica, resinas;

- Substâncias antioxidantes;

- Aceleradores de cura, enxofre;

- Óleos e agentes promotores de adesão e flexibilidade.

Os negros-de-fumo (responsáveis pela cor dos pneus) ocupam um lugar preponderante na fabricação dos pneus, pois conferem às misturas de borrachas propriedades mecânicas que permitem decuplicar sua resistência ao desgaste.

Um pneu de veículo de passeio típico (Goodyear P195/75R14), com massa aproximada de $10 \mathrm{~kg}$, contém (TNRCC, 1999):

- $2,5 \mathrm{~kg}$ de 30 diferentes tipos de borracha sintética;

- 2,0 kg de 8 diferentes tipos de borracha natural;

- $2,5 \mathrm{~kg}$ de 8 tipos de negro-de-fumo;

- $0,75 \mathrm{~kg}$ de aço para as cinturas;

- $0,5 \mathrm{~kg}$ de poliéster e náilon;

- $0,25 \mathrm{~kg}$ de arames de aço;

- $1,5 \mathrm{~kg}$ de 40 diferentes tipos de produtos químicos, óleos, pigmentos etc. 
Este pneu novo é, portanto, constituído de $45 \%$ de borracha, 25\% de negro-defumo, $15 \%$ de aditivos químicos, $10 \%$ de aço e $5 \%$ de lona. Quando precisa ser substituído, sua carcaça ainda pesa algo em torno de $8,5 \mathrm{~kg}$, contendo a mesma quantidade de aço e lona.

Estima-se que aproximadamente $0,03 \mathrm{~g}$ de pó de borracha seja eliminado em cada quilometro percorrido, devido ao desgaste provocado pelo contato da banda de rodagem com o pavimento. Não se conhece qual o impacto provocado pelo lançamento desse material particulado no ambiente. Estudos realizados no Reino Unido sugerem que os níveis de hidrocarbonetos aromáticos e substâncias particuladas atribuídas ao desgaste dos pneus excedem as emissões veiculares, sendo responsável por impactos negativos à saúde da população. Estudos realizados na Alemanha também atribuem ao desgaste dos pneus a presença de zinco e outros metais encontrados nos arredores das rodovias (ENVIRONMENTAL AUSTRALIA, 2001).

Em termos de volume, um metro cúbico pode conter aproximadamente 13 pneus de carro ou 4 pneus de caminhão (TNRCC, 1999). OLIVEIRA et al. (2000) destacam que a trituração dos pneus permite reduzir o volume ocupado em até $70 \%$.

\section{2 - O Descarte dos Pneus}

Os pneus apresentam degradação muito lenta e baixo grau de compactação, que inviabilizam sua disposição final, em condições normais, em aterros sanitários. Outro problema relacionado ao pneu inteiro quando enterrado é a sua tendência em subir e sair para a superfície, devido ao espaço vazio existente em sua forma (EPA, 1991). 
Os pneus geralmente são armazenados de forma inadequada em fundos de quintais, borracharias, ferros-velhos, recauchutadoras ou são lançados em terrenos baldios, cursos de água etc. As pilhas de pneus representam risco constante de incêndios, que são de difícil controle, produzem grande quantidade de fumaça tóxica (dióxido de enxofre) e deixam como resíduo óleos que podem contaminar as águas subterrâneas (EPPS, 1994).

A Figura 4 reproduz uma foto publicada no jornal $O$ Estado de $S$. Paulo (Caderno Cidades, 16 jan. 1999, p. 1) que mostra o acúmulo de lixo nas margens do rio Tietê, resultado do trabalho de desassoreamento. $\mathrm{O}$ entulho prejudica a vazão e acelera o transbordamento quando o volume de chuvas é elevado. Segundo o editorial A burocracia contra o Tietê (O Estado de $S$. Paulo, 19 jan. 1999, p.3), são retirados do rio Tietê cerca de 2.500 toneladas de lixo por mês; as carcaças de pneus representam aproximadamente $20 \%$ do volume dos resíduos retirados.

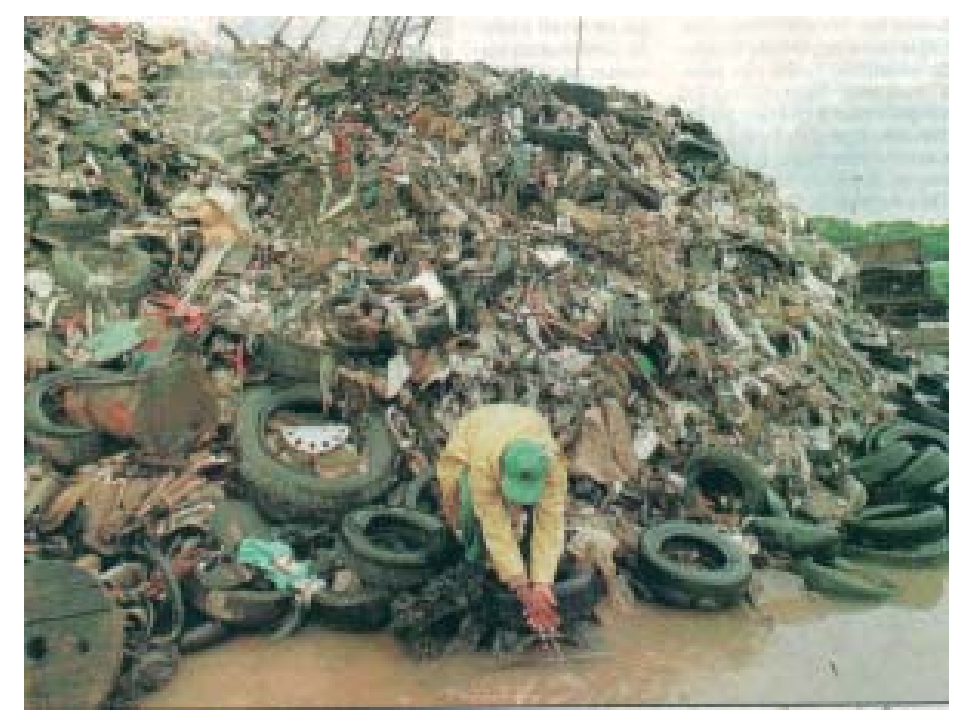

FIGURA 4 - Lixo acumulado nas margens do rio Tietê (PAIVA, 1999).

Devido ao formato físico e à impermeabilidade da borracha, os pneus podem armazenar água de chuva, propiciando um ambiente ideal para a procriação de mosquitos, roedores e outros vetores de doenças. 
Em 1996, a Superintendência de Controle de Endemias - SUCEN realizou um levantamento em municípios paulistas com a finalidade de identificar e eliminar os focos do mosquito Aedes aegypti. A Tabela 1 apresenta a distribuição percentual dos recipientes existentes e positivos para larvas de Aedes aegypti nos domicílios, conforme o tipo de recipiente.

TABELA 1 - Distribuição percentual dos recipientes existentes e positivos para larvas de Aedes aegypti, para o estado de São Paulo (SUCEN, 1996).

\begin{tabular}{lcccccc}
\hline $\begin{array}{l}\text { Tipo de } \\
\text { Recipiente }\end{array}$ & Pneu & $\begin{array}{c}\text { Armazenamento } \\
\text { de água }\end{array}$ & Vasos & Bebedouro & $\begin{array}{c}\text { Latas / } \\
\text { Frascos }\end{array}$ & Outros \\
\hline $\begin{array}{l}\text { Recipiente } \\
\text { Existente }\end{array}$ & 2,9 & 2,3 & 47,6 & 6,2 & 20,2 & 20,8 \\
\hline $\begin{array}{l}\text { Recipiente } \\
\text { Positivo }\end{array}$ & 12,0 & 7,8 & 29,6 & 8,4 & 24,6 & 17,6 \\
\hline
\end{tabular}

Observa-se a presença dos pneus, com $2,9 \%$ do total de recipientes encontrados, mas com uma positividade para larvas de Aedes aegypti que alcança $12 \%$ do total de focos, o que representa a maior relação "recipiente positivo/recipiente existente", evidenciando a preferência do mosquito transmissor da dengue e da febre amarela urbana pelos pneus quando vai colocar seus ovos.

Esse dado é extremamente importante, pois epidemias de dengue têm ocorrido em todo o Brasil. A situação no estado de São Paulo agravou-se em 1998, quando foram contaminadas pelo mosquito 10.629 pessoas, ante $2.037 \mathrm{em}$ 1997, e tornou-se crítica em 2001, quando foram notificados 48.024 casos da doença nos primeiros oito meses do ano (SUCEN, 2001). Logo, em ação conjunta com as autoridades ambientais, deve-se incentivar o recolhimento e armazenamento dos pneus em condições adequadas, procurando-se um mercado para a sua reutilização e reciclagem. 


\section{3 - Disponibilidade de Pneus Usados}

Um dos objetivos desta pesquisa foi realizar o levantamento do montante de pneus descartados e estocados em aterros sanitários de algumas cidades do estado de São Paulo. Não foram considerados métodos estatísticos na definição da amostragem, sendo selecionadas cidades distribuídas por quase todas as regiões do estado de São Paulo e consideradas importantes por serem pólos industriais, de comércio, de produção agrícola e agropecuária (Figura 5).

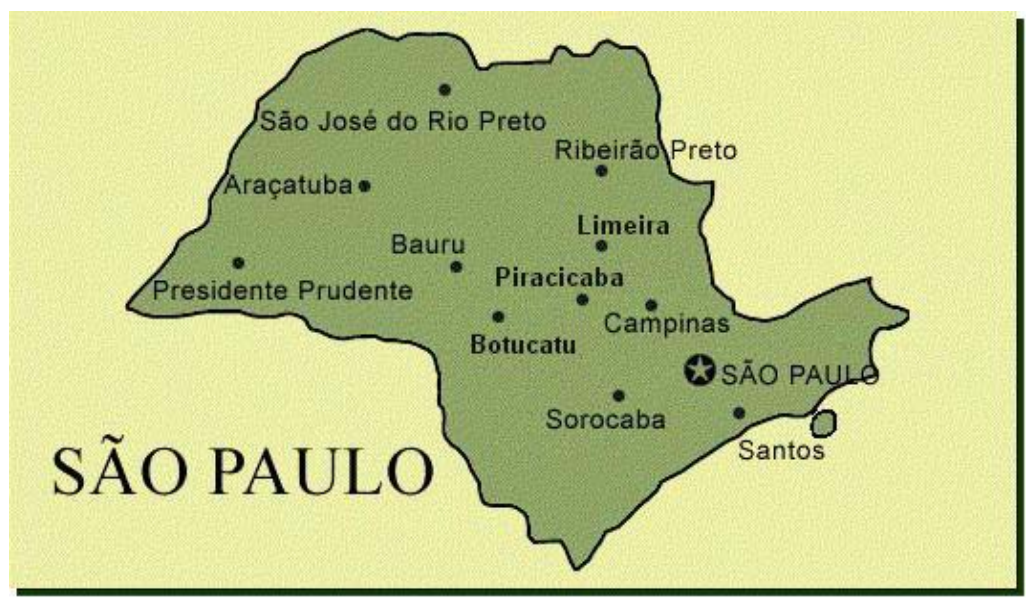

FIGURA 5 - Municípios onde foram feitos os levantamentos de quantidade e formas de disposição dos pneus inservíveis.

Para obtenção das informações foram feitos contatos com as prefeituras municipais, realizadas visitas técnicas e foi elaborado um questionário (Figura 6) tendo como itens principais: informações gerais sobre o aterro, volume de resíduos sólidos gerados e coleta/disposição dos pneus. A Tabela 2 resume as informações sobre coleta/disposição dos pneus obtidas em 12 cidades do estado de São Paulo: São Paulo, Ribeirão Preto, Limeira, Bauru, Piracicaba, Campinas, Sorocaba, São José do Rio Preto, Santos, Araçatuba, Presidente Prudente e Botucatu. 


\section{Questionário Preliminar}

Cidade:

Data:

População:

Empresa que administra o aterro:

Aterro:

- Informações gerais sobre $\mathrm{o}$ aterro:

- Quando começou a operar

- Quem projetou (possui aprovação da CETESB/SMA)

- Volume previsto

- Vida útil

- Qual o volume de lixo coletado por dia? Existe algum programa de reaproveitamento de lixo?

- Quantos pneus chegam por dia ao aterro?

- Existe alguma estimativa sobre o volume de pneus existente no aterro?

- O volume de pneus representa quanto do volume total de rejeitos existente?

- São aceitos pneus inteiros? Como são armazenados (são triturados / incinerados)? Qual a taxa cobrada para o recebimento de pneus?

- Os pneus representam um problema?

FIGURA 6 - Questionário para obtenção das informações referentes à disposição final dos pneus. 
TABELA 2 - Levantamento da quantidade de pneus descartados e estocados em algumas cidades do estado de São Paulo.

\begin{tabular}{|c|c|}
\hline Município & Situação \\
\hline $\begin{array}{l}\text { População abrangida: } \\
9.839 .066 \\
\text { (IBGE, 1996) }\end{array}$ & $\begin{array}{l}\text { Aterro Bandeirantes: } \\
\text { A descarga específica de grandes quantidades de pneus é esporádica. } \\
\text { Normalmente os pneus vêm misturados aos resíduos domiciliares. } \\
\text { Logo, não é realizado o controle da entrada de pneus. } \\
\text { Os pneus são aceitos inteiros no aterro, não existindo local } \\
\text { específico para armazenamento. } \\
\text { A taxa cobrada pela Prefeitura para o recebimento de resíduos } \\
\text { industriais classe II e comerciais (inclusive pneus) no aterro é de } \\
\text { R } \$ 48,30 / \text { tonelada. } \\
\text { Fonte: Departamento de Limpeza Urbana do Município de São } \\
\text { Paulo (Limpurb) - Jan } / 98\end{array}$ \\
\hline $\begin{array}{l}\text { População abrangida: } \\
302.886 \\
\text { (IBGE, 1996) }\end{array}$ & $\begin{array}{l}\text { Aterro sanitário do "Pau Queimado": } \\
\text { Chegam ao aterro aproximadamente } 100 \text { pneus por dia. Existe uma } \\
\text { área específica dentro do município (área rural) para que a população } \\
\text { possa jogar os pneus, sendo que não há cobrança de taxas. } \\
\text { Estima-se que atualmente aproximadamente } 10.000 \text { pneus inteiros } \\
\text { (de diversos tamanhos) estejam estocados no aterro. Piracicaba está } \\
\text { desenvolvendo um programa de reutilização de pneus no controle de } \\
\text { erosão do solo, onde são utilizados pneus estocados no aterro. } \\
\text { Fonte: Secretaria Municipal de Defesa do Meio Ambiente } \\
\text { (SEDEMA) - Mar/98 }\end{array}$ \\
\hline $\begin{array}{l}\text { População abrangida: } \\
230.348 \\
\text { (IBGE, 1996) }\end{array}$ & $\begin{array}{l}\text { Entre os dias } 29 \text { de janeiro e } 15 \text { de junho de } 1998 \text { foram recolhidos } \\
\text { um total de } 8.838 \text { pneus }(90.925 \mathrm{~kg} \text { ) durante visitas a } 28 \\
\text { borracharias. Este trabalho foi realizado pelo serviço de controle de } \\
\text { zoonoses, para a prevenção da transmissão da dengue. } \\
\text { No aterro existe uma área específica para o descarte de pneus. } \\
\text { Entretanto, não há estimativas do volume de pneus armazenados no } \\
\text { aterro sanitário (o trabalho de contagem está sendo feito). } \\
\text { Os pneus são armazenados inteiros. Existem projetos no sentido de } \\
\text { usar pneus na drenagem de chorume no aterro. } \\
\text { Fonte: Empresa de Desenvolvimento de Limeira (ENDEL) - Jul/98 }\end{array}$ \\
\hline $\begin{array}{l}\text { População abrangida: } \\
456.252 \\
\text { (IBGE, 1996) }\end{array}$ & $\begin{array}{l}\text { Não existe controle sobre a quantidade de pneus que chegam por dia } \\
\text { ao aterro. Estima-se que } 15.000 \text { pneus estejam enterrados nas saias } \\
\text { dos taludes (são lançados } 4 \text { metros de lixo bem compactados sobre } \\
\text { os pneus, para evitar o afloramento dos mesmos). } \\
\text { Aproximadamente } 15 \% \text { dos rejeitos existentes no aterro é formado } \\
\text { por pneus (em termos de volume). } \\
\text { São recebidos pneus inteiros, não sendo cobradas taxas no } \\
\text { recebimento. } \\
\text { Fonte: Departamento de Urbanização e Saneamento de Ribeirão } \\
\text { Preto (DURSARP) - Jul/98 }\end{array}$ \\
\hline
\end{tabular}


TABELA 2 - Levantamento da quantidade de pneus descartados e estocados em algumas cidades do estado de São Paulo (continuação).

\begin{tabular}{|c|c|}
\hline Município & Situação \\
\hline Bauru & $\begin{array}{l}\text { Foi criado junto ao aterro sanitário um pequeno aterro para pneus, } \\
\text { que é utilizado em situações de emergência, como por exemplo nos } \\
\text { arrastões de limpeza organizados pela Secretaria da Saúde para o } \\
\text { controle do transmissor da dengue. }\end{array}$ \\
\hline \multirow{3}{*}{$\begin{array}{l}\text { População abrangida: } \\
292.566 \\
\text { (IBGE, 1996) }\end{array}$} & $\begin{array}{l}\text { Estima-se que o município produza } 6.000 \text { pneus inservíveis por mês. } \\
\text { Não existe estimativa sobre o volume de pneus armazenados no } \\
\text { aterro. Os pneus são dispostos inteiros, em camadas e aterrados. }\end{array}$ \\
\hline & Não existem taxas para a descarga de pneus no aterro sanitário. \\
\hline & $\begin{array}{l}\text { Fonte: Prefeitura Municipal de Bauru - Departamento de Limpeza } \\
\text { Pública - Jul/98 }\end{array}$ \\
\hline Presidente Prudente & $\begin{array}{l}\text { Estima-se uma média de recebimento de } 30 \text { pneus por dia, sendo que } \\
\text { os mesmos são enterrados. }\end{array}$ \\
\hline \multirow{2}{*}{$\begin{array}{l}\text { População abrangida: } \\
177.367 \\
\text { (IBGE, 1996) }\end{array}$} & $\begin{array}{l}\text { Não existe cobrança de taxa para o recebimento dos pneus. Os pneus } \\
\text { são aceitos inteiros, sendo separados do lixo domiciliar apenas para } \\
\text { facilitar a compactação. }\end{array}$ \\
\hline & $\begin{array}{l}\text { Fonte: PRUDENCO - Companhia Prudentina de Desenvolvimento - } \\
\text { Abr/99 }\end{array}$ \\
\hline Botucatu & $\begin{array}{l}\text { O aterro não recebe pneus, uma vez que não é permitido esse tipo de } \\
\text { coleta pela Prefeitura. Entretanto, é de aproximadamente } 35.000 \text { o }\end{array}$ \\
\hline \multirow{2}{*}{$\begin{array}{l}\text { População abrangida: } \\
100.083 \\
\text { (IBGE, 1996) }\end{array}$} & $\begin{array}{l}\text { número de veículos cadastrados na cidade, que geram cerca de } \\
25.000 \text { pneus por ano. }\end{array}$ \\
\hline & Fonte: Secretaria Municipal do Meio Ambiente - Abr/99 \\
\hline \multirow{4}{*}{$\begin{array}{l}\text { Araçatuba } \\
\text { População abrangida: } \\
162.577 \\
\text { (IBGE, 1996) }\end{array}$} & $\begin{array}{l}\text { Todo os resíduos coletados na cidade são dispostos em lixão a céu } \\
\text { aberto. }\end{array}$ \\
\hline & $\begin{array}{l}\text { Não existe coleta de pneus velhos por parte da Prefeitura, porém as } \\
\text { borracharias descartam os pneus que não servem para } \\
\text { recauchutagem no referido lixão. }\end{array}$ \\
\hline & $\begin{array}{l}\text { Não existem informações quanto ao volume de pneus hoje existente } \\
\text { no local. Acredita-se que os pneus também são dispostos em } \\
\text { depósitos clandestinos. }\end{array}$ \\
\hline & Fonte: Secretaria de Obras - Mar/99 \\
\hline \multirow{2}{*}{$\begin{array}{l}\text { São José do Rio } \\
\text { Preto }\end{array}$} & \\
\hline & $\begin{array}{l}\text { O aterro sanitário não recebe pneus. A prefeitura faz a coleta e } \\
\text { armazena os pneus em uma área de sua propriedade. Estão sendo } \\
\text { realizados estudos de alternativas para o reaproveitamento. }\end{array}$ \\
\hline $\begin{array}{l}\text { População abrangida: } \\
323.627 \\
\text { (IBGE, 1996) }\end{array}$ & Fonte: Construfert Indústria e Comércio Ltda. - Abr/99 \\
\hline
\end{tabular}


TABELA 2 - Levantamento da quantidade de pneus descartados e estocados em algumas cidades do estado de São Paulo (continuação).

\begin{tabular}{|c|c|}
\hline Mur & Situação \\
\hline $\begin{array}{l}\text { População abrangida: } \\
412.243 \\
\text { (IBGE, 1996) }\end{array}$ & $\begin{array}{l}\text { Não existe controle da quantidade de pneus que chegam diariamente } \\
\text { no aterro. Estima-se um recebimento de } 200 \text { pneus/dia. Não existe } \\
\text { estimativa quanto ao volume de pneus existente no aterro. Não } \\
\text { existem trituradores no aterro. } \\
\text { Os pneus são coletados pelo Cata-Treco (programa de coleta nos } \\
\text { bairros) e misturado com outros entulhos. } \\
\text { Não existe cobrança de taxa para a disposição final dos pneus no } \\
\text { aterro. } \\
\text { A Prodesan, empresa de economia mista da Prefeitura Municipal de } \\
\text { Santos, é responsável pela manutenção dos pavimentos da cidade e } \\
\text { conta com o apoio da administração municipal no sentido de } \\
\text { desenvolver estudos visando utilizar borracha de pneu em misturas } \\
\text { asfálticas. Foram construídos trechos experimentais onde foram } \\
\text { incorporadas raspas de borracha obtidas em empresas de } \\
\text { recauchutagem. O consumo girou em torno de } 30 \mathrm{~kg} \text { de borracha por } \\
\text { tonelada de mistura. Segundo informações da Prefeitura, esses } \\
\text { pavimentos têm apresentado bom desempenho. } \\
\text { Fonte: Terracom Engenharia Ltda e PRODESAN Progresso e } \\
\text { Desenvolvimento de Santos S/A - Abr/99 }\end{array}$ \\
\hline $\begin{array}{l}\text { População abrangida: } \\
431.561 \\
\text { (IBGE, 1996) }\end{array}$ & $\begin{array}{l}\text { Entre } 1993 \text { e } 1998 \text {, o Serviço de Prevenção e Controle de Zoonoses } \\
\text { recolheu } 119.979 \text { pneus. Até } 1998 \text { os pneus estavam sendo enviados } \\
\text { pelas borracharias e pelo órgão de controle de zoonoses para } 2 \\
\text { barracões da Prefeitura, onde eram armazenados. Como os galpões } \\
\text { estão com sua capacidade esgotada, o aterro voltou a receber pneus } \\
\text { na sua forma inteira. Não são cobradas taxas para o recebimento dos } \\
\text { pneus já que o aterro não recebe pneus de particulares. } \\
\text { Fonte: Serviço de Prevenção e Controle de Zoonoses - Abr/99 }\end{array}$ \\
\hline $\begin{array}{l}\text { População abrangida: } \\
908.906 \\
\text { (IBGE, 1996) }\end{array}$ & $\begin{array}{l}\text { Aterro Sanitário Delta I } \\
\text { Pneus não são coletados pelos caminhões da Prefeitura, não sendo } \\
\text { permitida a entrada desse tipo de resíduo no aterro Delta I. } \\
\text { Fonte: Departamento de Limpeza Urbana - Abr/99 }\end{array}$ \\
\hline
\end{tabular}

Com base nos números obtidos, tem-se uma geração anual média per capita para o estado de São Paulo igual a 0,14, ou seja, aproximadamente 5 milhões de pneus são descartados anualmente. Comparando-se com dados de outros países, pode-se suspeitar que esse número está subestimado, provavelmente em razão dos vários artifícios utilizados para a disposição clandestina e da 
falta de recursos para a coibição de tal prática. No Canadá, por exemplo, cerca de 30 milhões de pneus são descartados anualmente (ZANZOTTO \& KENNEPOHL, 1996). Na Rússia, país com 147 milhões de habitantes, cerca de 1,1 milhões de toneladas de pneus são descartados a cada ano (NIKOULICHEV, 1999). Na Austrália, país com 18,9 milhões de habitantes, aproximadamente 70.000 toneladas de pneus inservíveis são geradas a cada ano (ENVIRONMENT AUSTRALIA, 2001). Na Europa, mais de 2,5 milhões de toneladas de pneus chegam ao fim de sua vida a cada ano, o que representa uma geração anual de aproximadamente 235 milhões de pneus. A Tabela 3 apresenta uma estimativa da geração anual de carcaças de pneus nos países membros da Comunidade Européia (adaptado de UTWG, 2001).

TABELA 3 - Geração anual de pneus nos países da Comunidade Européia (adaptado de UTWG, 2001).

\begin{tabular}{lrrc}
\hline País & Pneus/Ano (t) & População & $\begin{array}{c}\text { Pneu/Pessoa/Ano } \\
\text { (estimativa) }\end{array}$ \\
\hline Áustria & 50.000 & 8.045 .800 & 0,58 \\
Bélgica & 70.000 & 10.143 .000 & 0,65 \\
Dinamarca & 37.500 & 5.251 .600 & 0,67 \\
Finlândia & 30.000 & 5.116 .000 & 0,55 \\
França & 370.000 & 58.265 .400 & 0,60 \\
Alemanha & 650.000 & 81.845 .000 & 0,75 \\
Grécia & 58.500 & 10.474 .600 & 0,53 \\
Irlanda & 32.000 & 3.591 .200 & 0,84 \\
Itália & 350.000 & 57.330 .500 & 0,57 \\
Luxemburgo & 2.750 & 412.800 & 0,63 \\
Países Baixos & 67.000 & 15.492 .800 & 0,41 \\
Portugal & 52.000 & 9.920 .800 & 0,49 \\
Espanha & 244.000 & 39.241 .900 & 0,59 \\
Suécia & 60.000 & 8.737 .500 & 0,65 \\
Reino Unido & 427.000 & 58.684 .000 & 0,68 \\
\hline Total & $\mathbf{2 . 5 0 0 . 7 5 0}$ & $\mathbf{3 7 2 . 5 5 2 . 9 0 0}$ & \\
\hline
\end{tabular}


Nenhum país produz mais pneus inservíveis que os Estados Unidos. Estima-se que sejam dispostos 273 milhões de pneus por ano, algo em torno de 3,6 milhões de toneladas, o que representa mais de um pneu por habitante por ano (RMA, 2000).

Na cidade de Londrina, no Paraná, COSTA et al. (2000) realizaram um levantamento através da aplicação de questionário como instrumento para quantificar o número de pneus descartados mensalmente na cidade. $\mathrm{O}$ levantamento, realizado em estabelecimentos que atuam no ramo de pneumáticos (consertos, vendas ou recuperação de pneus), indicou um descarte de 17.000 pneus por mês, o que equivale a 204.000 unidades por ano ou $0,46 \mathrm{pneu} / \mathrm{pessoa/ano.} \mathrm{Este} \mathrm{número} \mathrm{de} \mathrm{pneus} \mathrm{está} \mathrm{muito} \mathrm{próximo} \mathrm{do} \mathrm{cálculo}$ da estimativa de descarte baseado na frota de veículos existentes em Londrina (cerca de 19.000 pneus/mês).

Segundo a Empresa Brasileira de Planejamento de Transportes (GEIPOT, 2001a), o estado de São Paulo conta com 12.872.845 veículos registrados (nacionais e importados), que representam 38\% da frota brasileira. A Tabela 4 apresenta o número de veículos automotores em 1999 e a população de acordo com o Censo Demográfico de 2000 no estado de São Paulo e no Brasil.

TABELA 4 - Frota de veículos automotores em 1999 no estado de São Paulo e no Brasil (GEIPOT, 2001a) e população de acordo com o Censo Demográfico 2000 (IBGE, 2001).

\begin{tabular}{|c|c|c|c|c|c|c|c|c|}
\hline \multirow{3}{*}{ Região } & \multicolumn{7}{|c|}{ Classe de Veículos } & \multirow{3}{*}{$\begin{array}{l}\text { População } \\
\text { (IBGE, 2001) }\end{array}$} \\
\hline & \multirow{2}{*}{ Passeio } & \multirow{2}{*}{$\begin{array}{l}\text { Comercial } \\
\text { Leve }\end{array}$} & \multicolumn{2}{|c|}{ Transporte } & \multirow{2}{*}{$\begin{array}{l}\text { Biciclos } \\
\text { Triciclos }\end{array}$} & \multirow{2}{*}{$\begin{array}{c}\text { Total } \\
\text { Nacional }\end{array}$} & \multirow{2}{*}{$\begin{array}{c}\text { Total } \\
\text { Import. }\end{array}$} & \\
\hline & & & Coletivo & Carga & & & & \\
\hline SP & 8.897 .951 & 1.094 .319 & 137.844 & 561.499 & 1.392 .060 & 12.083 .673 & 789.172 & 36.969 .476 \\
\hline Brasil & 22.347 .423 & 3.193 .058 & 400.048 & 1.778 .084 & 4.222 .705 & 31.941 .318 & 1.858 .205 & 169.590 .693 \\
\hline
\end{tabular}


Considerando-se que aproximadamente $80 \%$ da frota é composta por automóveis e caminhonetes, veículos que contribuem com a quase totalidade dos pneus descartados devido à sua predominância e à maior dificuldade de reciclagem, pode-se calcular o descarte a partir das seguintes premissas: a frota de veículos de passeio e comercial leve no estado de São Paulo é de 10.298.276 veículos e a durabilidade média do pneu novo é de dois anos. Segundo TOMMASINI (2000), da totalidade dos pneus de automóveis substituídos na rede de revendedores autorizados, $20 \%$ são mantidos com o proprietário; dos $80 \%$ coletados pelos sucateiros, apenas $22 \%$ são recauchutados.

Logo, em dois anos seriam descartados cerca de 33.943.118 pneus, que representa um descarte anual de 16.971 .559 pneus de automóveis e caminhonetes no estado de São Paulo (0,46 pneu/pessoa/ano). Considerando a frota nacional, seriam descartados mais de 44 milhões de pneus por ano no Brasil (0,26 pneu/pessoa/ano).

\section{4 - ReduÇão, ReutilizaÇão e Reciclagem de Pneus Usados}

A disposição final de pneus inservíveis representa um problema de difícil solução, o que evidencia a necessidade da elaboração de medidas para minimizar a geração dos mesmos. $\mathrm{O}$ aumento da duração da vida útil de um pneu e o aprimoramento das técnicas de recauchutagem, que prolonga a vida da carcaça, são dois fatores que permitem reduzir a geração desses resíduos e o número de pneus a dispor corretamente. 
Os fabricantes têm procurado desenvolver tecnologias que aumentam a durabilidade dos pneus. Na Europa, a durabilidade de um pneu de passeio é da ordem dos $50.000 \mathrm{~km}$. Nos Estados Unidos, onde as condições de circulação são específicas, são comercializados pneus cuja duração de vida garantida chega a $130.000 \mathrm{~km}$, correspondente à do próprio automóvel. Já são comercializados pneus utilizados em veículos de carga cuja durabilidade chega aos $300.000 \mathrm{~km}$ (MICHELIN, 1999). Neste caso, quando são utilizados todos os recursos de recauchutagem, um pneu de carga pode chegar a percorrer cerca de $600.000 \mathrm{~km}$.

$\mathrm{Na}$ recauchutagem, a banda de rodagem desgastada é substituída através da aplicação de uma nova camada de borracha. Neste processo, uma mesma carcaça é aproveitada pelo menos duas vezes. A recauchutagem é um excelente meio para economizar recursos, pois a quantidade de borracha necessária para essa operação não representa mais do que 20 a 30\% da que é necessária para fabricar um pneu novo. Nos casos em que a carcaça apresenta condições insatisfatórias de uso, o recurso da recauchutagem não pode ser aplicado, gerando boa parte dos pneus inservíveis.

O fato é que todo pneu, em algum momento, se transformará em um resíduo potencialmente danoso à saúde pública e ao meio ambiente, e uma solução adequada para sua destinação final deve ser adotada. Têm sido realizadas pesquisas, particularmente no exterior, buscando o desenvolvimento de novas tecnologias para reutilizar pneus velhos, seja na sua forma inteira, como borracha reciclada ou como combustível na geração de energia. As Figuras 7 e 8 apresentam, respectivamente, o destino dado aos pneus descartados na União Européia (UTWG, 2001) e na Austrália (ENVIRONMENT AUSTRALIA, 2001). 


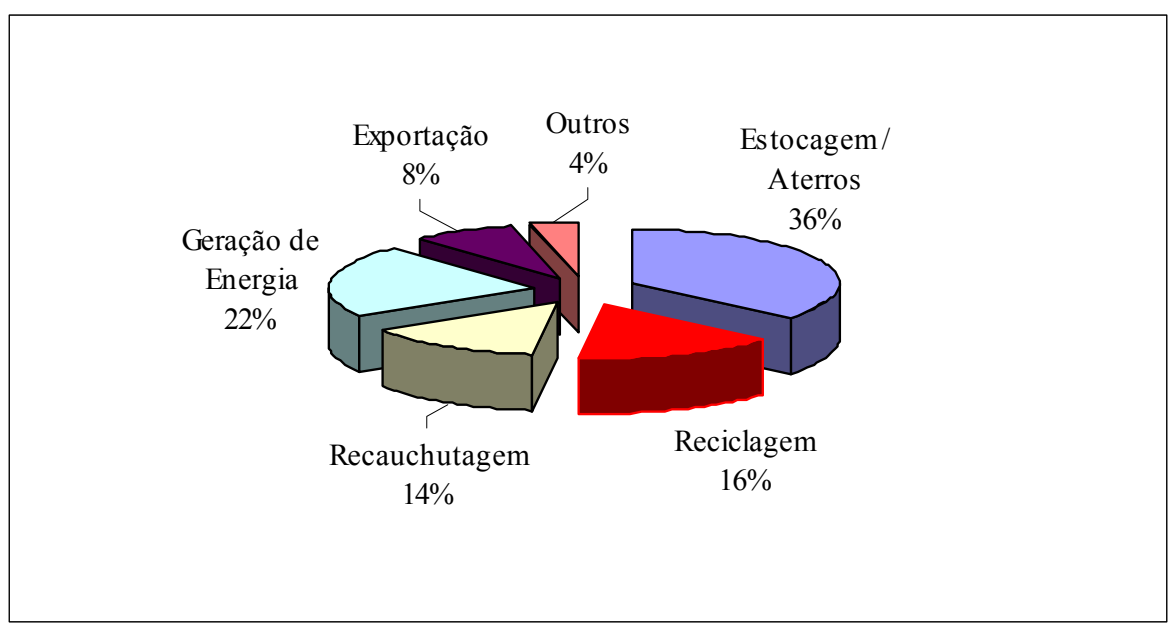

FIGURA 7 - Destino dos pneus usados na União Européia em 2000 (UTWG, 2001).

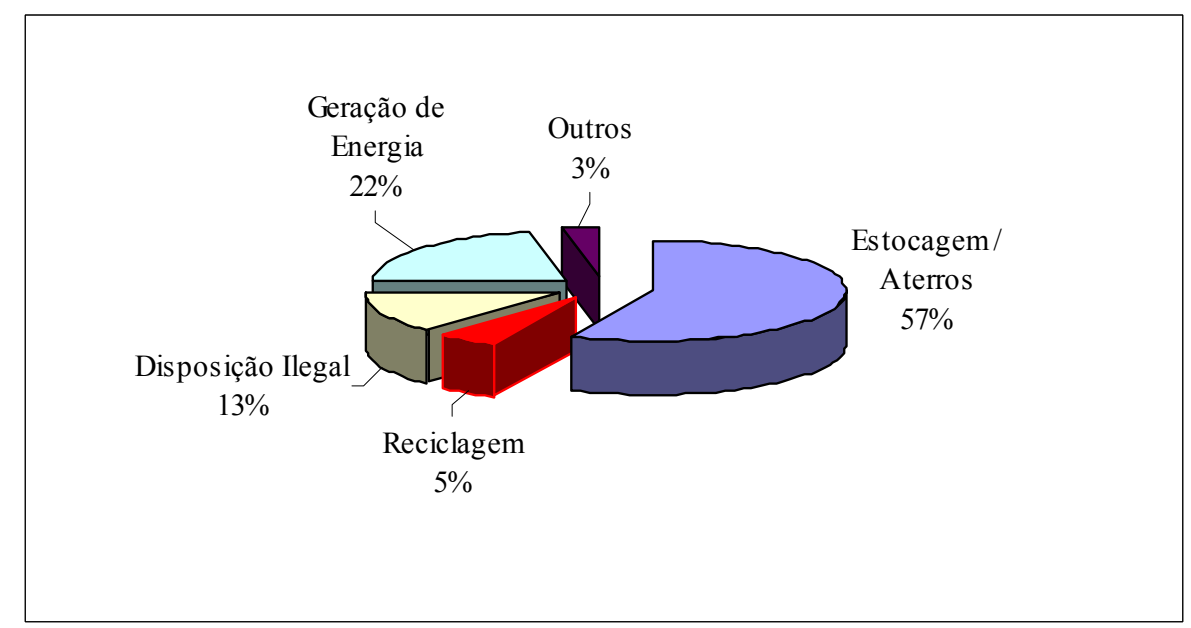

FIGURA 8 - Destino das carcaças de pneus na Austrália (ENVIRONMENT AUSTRALIA, 2001).

A Tabela 5 apresenta a evolução da destinação final dos pneus usados nos Estados Unidos em 1996 (EPA, 1999) e 2000 (RMA, 2000). 
TABELA 5 - Destinação das carcaças de pneus nos Estados Unidos em 1996 (EPA, 1999) e 2000 (RMA, 2000).

\begin{tabular}{lcc}
\hline Destinação das Carcaças de Pneus & $\mathbf{1 9 9 6}(\%)$ & $\mathbf{2 0 0 0}(\%)$ \\
\hline Reciclagem & 5 & 7 \\
Borracha Triturada & 3 & 3 \\
Laminados e transformados em novos produtos & 1 & - \\
Outros & 9 & 10 \\
\hline Total Reciclado & 4 & 11 \\
Na Engenharia Civil & 57 & 45 \\
Geração de Energia & 6 & 6 \\
Exportados & 24 & 28 \\
Em aterros, estocados ou dispostos ilegalmente & 266 milhões & 273 milhões \\
\hline Total Gerado (unidades)
\end{tabular}

O uso de carcaças de pneu na engenharia civil envolve soluções criativas, em aplicações bastante diversificadas e de baixo custo, podendo utilizar um número significativo de pneus através de ações simples de corte e fixação. Segundo EPPS (1994), os pneus inservíveis, na sua forma inteira, podem ser aplicados em obras de contenções, nas margens de rios para evitar desmoronamentos, como recifes artificiais, na construção de quebra-mares, na construção de equipamentos para parques infantis, como barreira em acostamento de estradas, no controle de erosão etc.

No Brasil, SILVA et al. (2000) relatam uma experiência de sucesso realizada na cidade de São Luis, no Maranhão, onde foram utilizados 30.000 pneus na construção de uma obra de contenção de talude, para evitar desmoronamentos. Pneus também estão sendo utilizados na construção de recifes artificiais, no litoral do Rio Grande do Norte, com objetivo de recuperar a flora marinha e aumentar o potencial pesqueiro. Segundo OLIVEIRA et al. (2000), somente no mês de julho de 2000 foram lançados ao mar cerca de 9.070 pneus. Os autores alertam que uma ação descuidada, sem a conscientização dos 
pescadores e o devido suporte técnico, poderia transformar o mar num "depósito de carcaças de pneus", o que vem ocorrendo em algumas praias com o aparecimento de pneus boiando em suas orlas. Além disso, é preciso analisar o comportamento desse tipo de resíduo quando submetidos à ação de águas salinas por longo tempo, o que torna necessário o constante monitoramento.

A Figura 9 ilustra uma experiência brasileira de utilização de pneus inteiros numa tentativa de controle de erosão. Na Figura 9(a) pode-se ver uma área erodida na cidade de Piracicaba, com profundidade aproximada de 30 metros e largura aproximada de 20 metros. A Figura 9(b) apresenta a mesma área, com profundidade de 10 metros, onde foram lançados 25.000 pneus. As fotos foram tiradas em março de 1998.

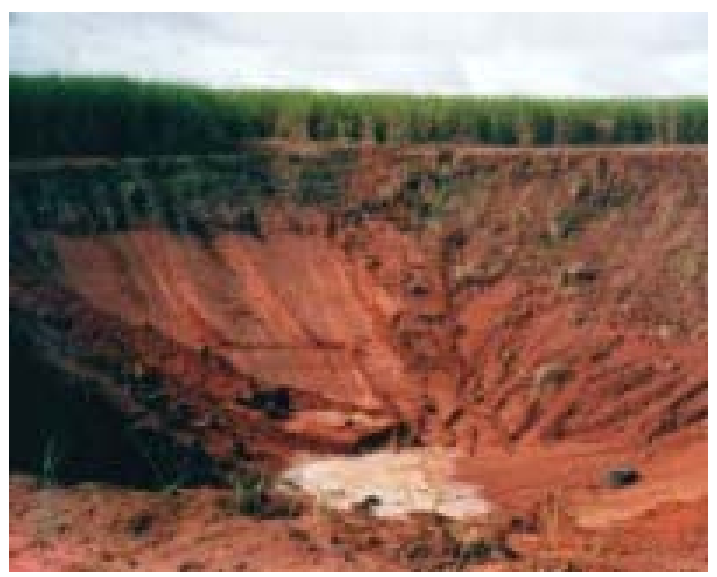

(a) Erosão em área rural

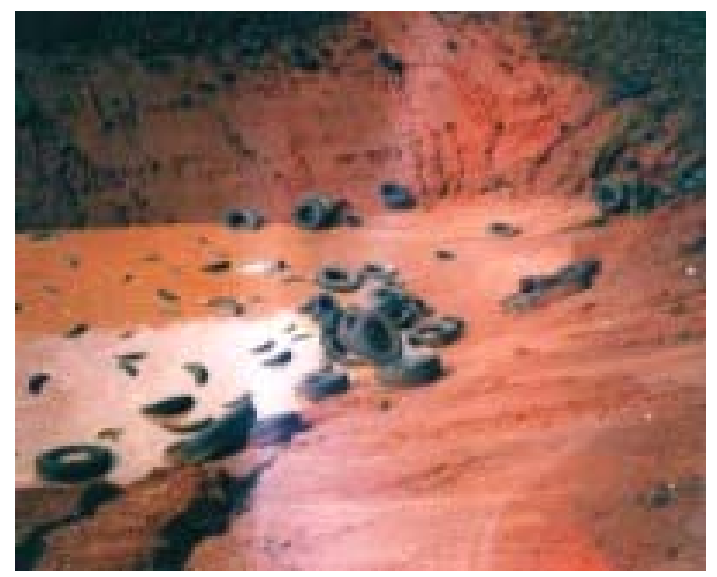

(b) Tentativa de recuperação

FIGURA 9 - Erosão em área rural do município de Piracicaba-SP (fotos tiradas em março de 1998).

É importante salientar que a utilização de pneus inteiros para controle de erosão requer que estes sejam dispostos adequadamente para impossibilitar a movimentação e que estes venham a subir e sair para a superfície, havendo muitas vezes a necessidade de dispositivos de fixação e o preenchimento dos 
pneus com areia ou brita. $\mathrm{O}$ emprego de pneus no controle de erosão, sem o devido suporte técnico, pode-se transformar em outro problema ambiental. O simples lançamento de pneus em áreas erodidas, como mostrado na Figura 9, é uma alternativa paliativa, que não contribui para o equacionamento do problema ambiental da disposição final dos pneus inservíveis. Na Austrália, os órgãos ambientais não recomendam que carcaças de pneus sejam utilizadas no controle de erosão devido às experiências mal-sucedidas (EPA, 2001).

A Figura 10 apresenta alguns exemplos de experiências internacionais de utilização de pneus no escoamento de água pluvial (TYREDRAIN, 2001).
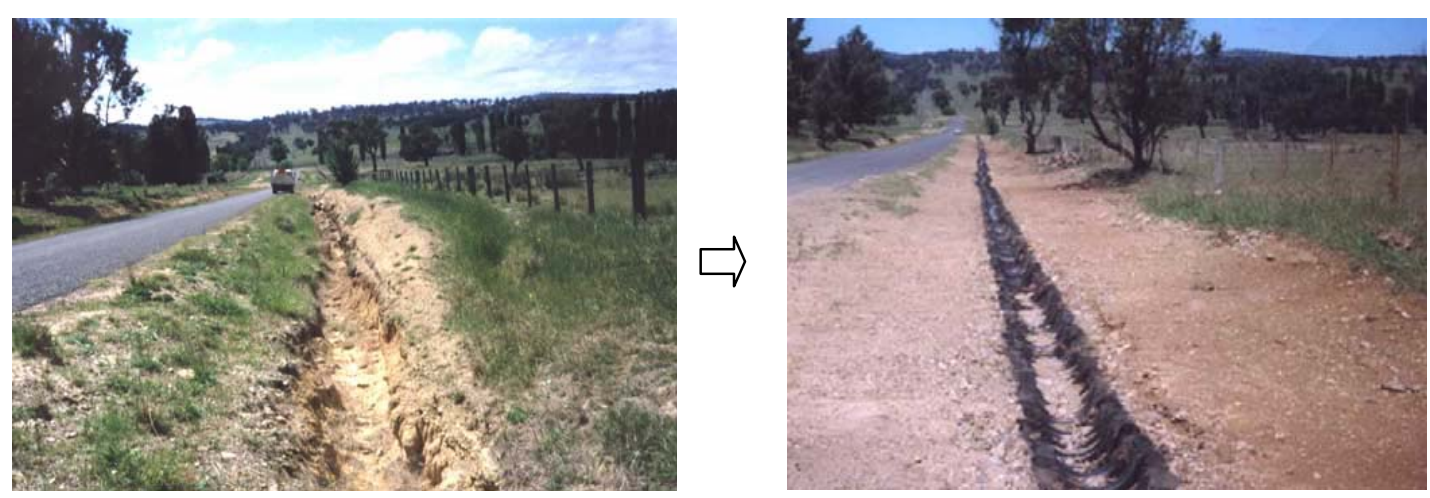

(a) Em acostamentos: drenagem utilizando "metades" de pneus

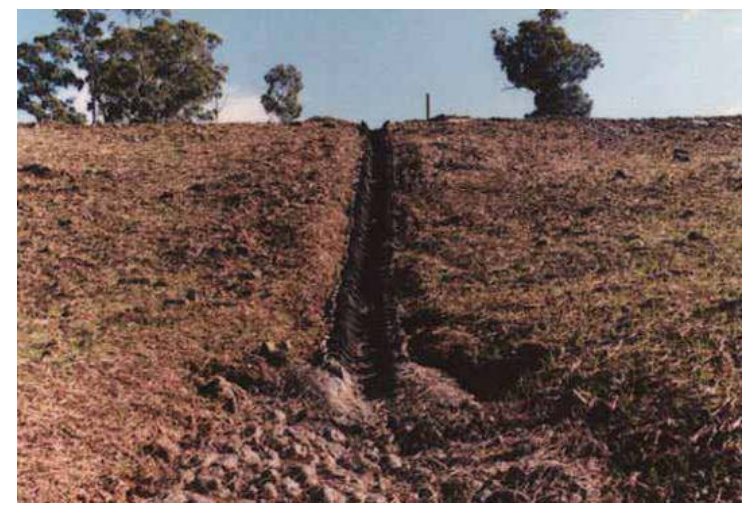

(b) Em taludes

FIGURA 10 - Exemplos de utilização de pneus no escoamento de água pluvial (TYREDRAIN, 2001). 
A Figura 11 apresenta uma experiência internacional na confecção de bueiros utilizando pneus de caminhões. Do pneu de caminhão são extraídas as partes laterais (flancos). Na confecção de cada segmento de 2,5 metros de tubulação, são utilizadas cerca de 80 laterais, que são empilhadas, comprimidas e presas por 4 tiras de aço no sentido longitudinal. As tiras de aço irão manter fixos os anéis de borracha (TRANSAFETY, 1997).
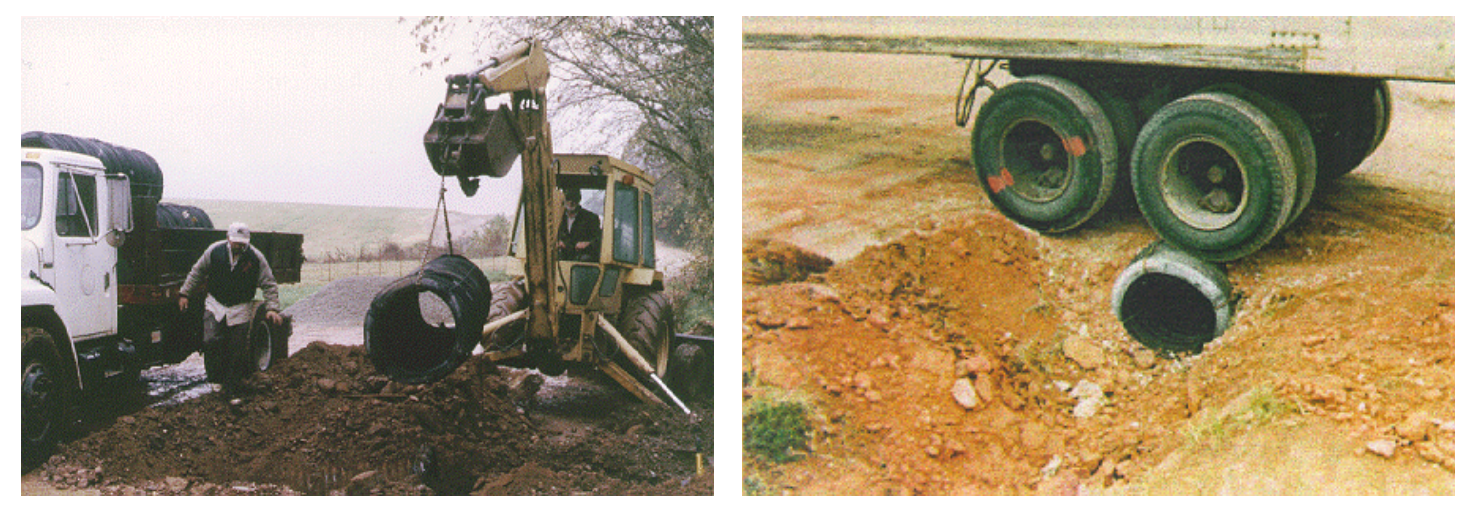

FIGURA 11 - Experiência internacional de reutilização de pneus na construção de bueiros (TRANSAFETY, 1997).

Pneus inteiros também podem ser utilizados como combustível em fábricas de celulose e papel (após a remoção do aço), em fornos de cimento (pode-se utilizar pneus inteiros, pois o aço acrescenta ferro ao cimento) e em usinas termelétricas. O poder calorífico de raspas de pneu equivale ao do óleo combustível, girando em torno de $40 \mathrm{MJ} / \mathrm{kg}$, sendo muito superior ao poder calorífico da madeira, que é de aproximadamente $14 \mathrm{MJ} / \mathrm{kg}$.

Nos Estados Unidos, cerca de 45\% dos pneus descartados são utilizados como combustível em 72 fábricas e usinas distribuídas pelo país (RMA, 2000). A Usina Termelétrica de Modesto, Califórnia, queima cerca de 4,5 milhões de 
pneus por ano. Existe uma segunda usina em Sterling, Connecticut, que consome cerca de 10 milhões de pneus por ano (EPA, 1991).

No Brasil, a queima de pneus para abastecer caldeiras de fábricas de cimento e cal ou em indústrias de papel e celulose é regulamentada por lei. A Companhia de Cimento Ciminas S. A., localizada na cidade de Pedro Leopoldo, Minas Gerais, vêm utilizando pneus como gerador de energia.

A queima de pneus inteiros diminui os gastos com operações de corte ou trituração. Entretanto, esse procedimento requer alta temperatura de combustão para manter as emissões de gases dentro dos limites permitidos, além dos mecanismos de alimentação dos fornos, que são mais caros para os pneus inteiros do que para pedaços de borracha (AMARI et al., 1999; SHARMA et al., 2000).

A utilização de pneus na geração de energia requer estudos mais aprofundados quanto às emissões atmosféricas, além de estudos da viabilidade econômica desse processo. $\mathrm{O}$ desprendimento de gases tóxicos e material particulado é muito grande e a instalação de um sistema de controle de poluentes, com equipamentos e monitorização ao longo do tempo, pode-se tornar uma solução economicamente inviável.

Do ponto de vista ambiental, a reciclagem das matérias-primas do pneu seria a solução mais satisfatória, desde que se pudesse recuperar materiais de qualidade a um custo energético mínimo. Mas o pneu não é verdadeiramente reciclável no sentido estrito do termo. O seu caráter compósito, bem como a irreversibilidade da reação de vulcanização, tornam impossível obter de novo as matérias-primas iniciais. 
No entanto, é possível recuperar e reutilizar parte dos pneus inservíveis. Os pneus são cortados e triturados, seguindo-se a isto operações de separação dos diferentes materiais, o que permite a recuperação dos materiais contidos nos pneus. Obtém-se desse modo borracha pulverizada ou granulada que vai ter diversas aplicações: utilização em misturas asfálticas, em revestimentos de quadras e pistas de esportes, fabricação de tapetes automotivos, adesivos etc.

Conforme destacam EPA (1991), HEITZMAN (1992) e ZANZOTTO \& KENNEPOHL (1996), quando são analisados os vários mercados para utilização de borracha de pneus inservíveis, dois têm apresentado potencial para consumir um número significativo de pneus: a utilização como combustível e a incorporação em misturas asfálticas.

Os riscos ambientais que envolvem a utilização de pneus como combustível e os custos envolvidos na instalação de equipamentos (filtros e fornos) para controle das emissões de poluentes, assim como a pressão de grupos ambientalistas, tem contribuído para uma tendência na redução de utilização desse tipo de combustível nos países europeus e nos Estados Unidos. Essa situação favorece o desenvolvimento de novas pesquisas visando a utilização de borracha triturada em obras de pavimentação.

Cada tonelada de mistura asfáltica pode incorporar a borracha de 1 a 4 pneus de veículos de passeio. Logo, para consumir cerca de 10 milhões de pneus por ano, necessitam-se de 2,5 a 7 milhões de toneladas de misturas asfálticas para a incorporação de borracha triturada. Para se ter uma idéia do que representam essas quantidades, 7 milhões de toneladas de mistura asfáltica modificada com borracha equivale à pavimentação de aproximadamente $6.000 \mathrm{~km}$ de rodovias. Considerou-se para tal estimativa, as dimensões conforme seção transversal ilustrada a seguir: 


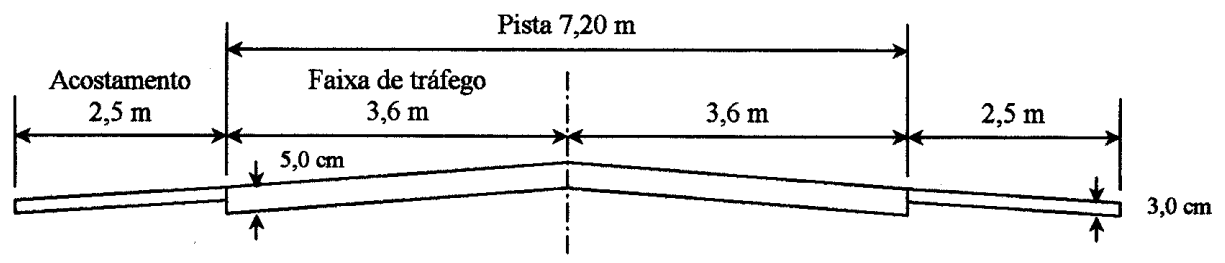

De acordo com o Anuário Estatístico dos Transportes (GEIPOT, 2001b), no período entre 1995 e 1999 foram pavimentados no Brasil cerca de $16.125 \mathrm{~km}$ de rodovias. Considerando que cada quilômetro pavimentado poderia consumir a borracha de 1.600 a 4.800 pneus, dependendo do teor de borracha e do tipo de pneu, o número de pneus usados consumidos no período seria, no mínimo, superior a 25 milhões de unidades. A Tabela 6 apresenta uma estimativa de consumo de pneus em pavimentação asfáltica, para cada região do Brasil, no período entre 1995 e 1999.

TABELA 6 - Extensão total das rodovias pavimentadas em 1995 e 1999 (GEIPOT, 2001b) e estimativa de consumo de pneus.

\begin{tabular}{lcccc}
\hline Região & $\begin{array}{c}\text { Extensão } \\
\text { Pavimentada } \\
\text { até } \mathbf{1 9 9 5}(\mathbf{k m})\end{array}$ & $\begin{array}{c}\text { Extensão } \\
\text { Pavimentada } \\
\text { até } \mathbf{1 9 9 9}(\mathbf{k m})\end{array}$ & $\begin{array}{c}\text { Total } \mathbf{( k m )} \\
\text { Pavimentado } \\
\text { entre 1995-99 }\end{array}$ & $\begin{array}{c}\text { Estimativa de } \\
\text { consumo de } \\
\text { pneus (mínimo) }\end{array}$ \\
\hline Norte & 8.442 & 12.083 & 3.641 & 5.825 .600 \\
Nordeste & 41.412 & 44.693 & 3.281 & 5.249 .600 \\
Sudeste & 51.879 & 54.216 & 2.337 & 3.739 .200 \\
Sul & 29.359 & 32.441 & 3.082 & 4.931 .200 \\
Centro-Oeste & 17.030 & 20.814 & 3.784 & 6.054 .400 \\
\hline Total & $\mathbf{1 4 8 . 1 2 2}$ & $\mathbf{1 6 4 . 2 4 7}$ & $\mathbf{1 6 . 1 2 5}$ & $\mathbf{2 5 . 8 0 0 . 0 0 0}$ \\
\hline
\end{tabular}

Em 1999 o Brasil possuía uma malha rodoviária com cerca de $1.724 .924 \mathrm{~km}$ de rodovias pavimentadas e não-pavimentadas. As rodovias pavimentadas representam menos de $10 \%(164.247 \mathrm{~km})$ da extensão total das rodovias brasileiras. A Tabela 7 apresenta dados de 1999 sobre a situação da malha rodoviária, por região brasileira. 
TABELA 7 - Extensão total das rodovias pavimentadas e não-pavimentadas em 1999, separadas por região (GEIPOT, 2001b).

\begin{tabular}{lccccc}
\hline \multirow{2}{*}{ Região } & Malha Rodoviária & \multicolumn{2}{c}{ Pavimentada } & \multicolumn{2}{c}{ Não-Pavimentada } \\
& $\mathbf{( k m )}$ & $\mathbf{( k m )}$ & $\mathbf{( \% )}$ & $\mathbf{( k m )}$ & $\mathbf{( \% )}$ \\
\hline Norte & 103.211 & 12.083 & 11,7 & 91.128 & 88,3 \\
Nordeste & 405.376 & 44.693 & 11,0 & 360.683 & 89,0 \\
Sudeste & 512.423 & 54.216 & 10,6 & 458.207 & 89,4 \\
Sul & 476.089 & 32.441 & 6,8 & 443.648 & 93,2 \\
Centro-Oeste & 227.825 & 20.814 & 9,1 & 207.011 & 90,9 \\
\hline Total & $\mathbf{1 . 7 2 4 . 9 2 4}$ & $\mathbf{1 6 4 . 2 4 7}$ & $\mathbf{9 , 5}$ & $\mathbf{1 . 5 6 0 . 6 7 7}$ & $\mathbf{9 0 , 5}$ \\
\hline
\end{tabular}

De acordo com pesquisa realizada em 2001 pela Confederação Nacional dos Transportes (CNT, 2001), o estado geral de conservação da malha rodoviária pavimentada Federal e Estadual foi considerado de péssimo a deficiente em $52,2 \%$ da extensão pesquisada. O restante apresentou estado de conservação do pavimento entre bom e ótimo. A Pesquisa Rodoviária CNT avaliou 40.217 $\mathrm{km}$ de rodovias federais pavimentadas ( $71,9 \%$ da malha rodoviária federal) e $5.077 \mathrm{~km}$ da malha rodoviária estadual. De modo geral, o estado de conservação dos pavimentos urbanos no Brasil encontra-se também bastante deteriorado (BERTOLLO, 1997).

A pavimentação de apenas $0,5 \%$ (cerca de $7.800 \mathrm{~km}$ ) do total de quilômetros de rodovias não-pavimentados poderia consumir mais de 12 milhões de pneus usados. A utilização de pneus triturados em obras de pavimentação no Brasil não deveria ser considerada como uma utopia, pois já é realidade na cidade de Santos, São Paulo, onde raspas de pneu (provenientes do processo de recauchutagem) são incorporadas nas misturas asfálticas ("processo seco") utilizadas nas atividades de reabilitação e construção de pavimentos (Figura 12). 

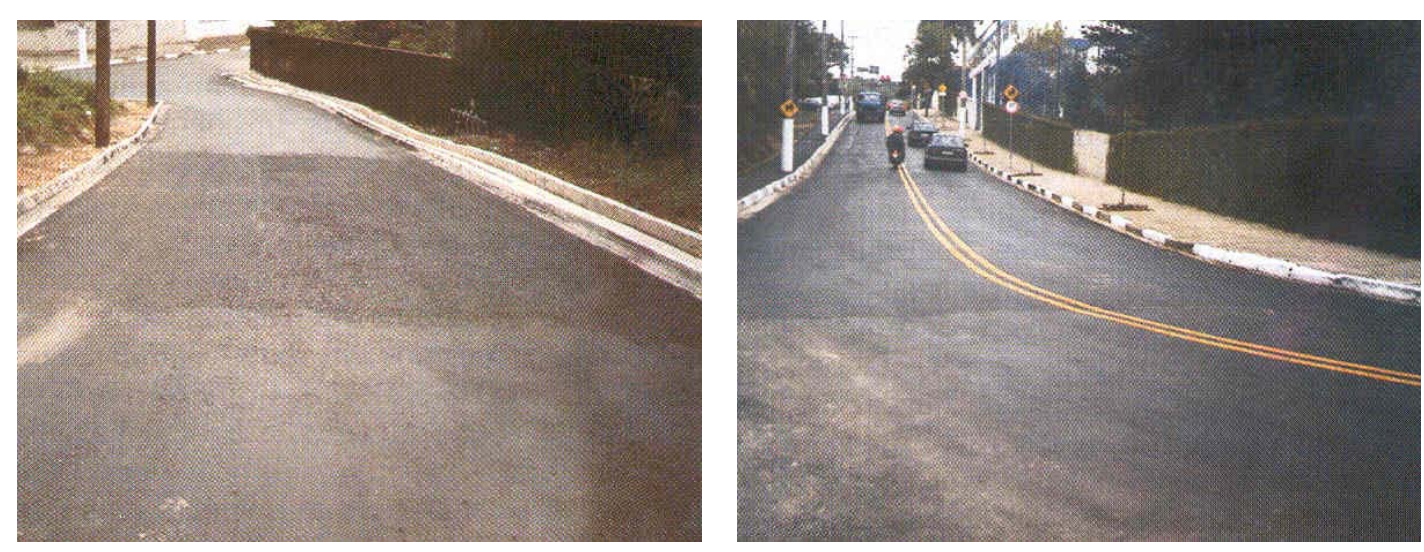

FIGURA 12 - Trechos de pavimentos modificados com adição de borracha de pneus na cidade de Santos-SP (BERTOLLO et al., 2000).

Segundo informações da Prefeitura de Santos-SP, alguns trechos experimentais têm apresentado excelente desempenho enquanto outros apresentam problemas de desagregação, o que evidencia a necessidade de pesquisas sobre a utilização de borracha reciclada de pneus em obras de pavimentação asfáltica no Brasil.

\section{5 -GESTÃo DE RESÍDUOS E LEGISLAÇ̃̃o}

\subsection{1 - Brasil}

No Brasil foi aprovada, em 26 de agosto de 1999, a resolução № 258 do Conselho Nacional do Meio Ambiente (CONAMA) que institui o conceito de responsabilidade do produtor e importador pelo ciclo total da mercadoria: a partir de janeiro de 2002, fabricantes e importadoras de pneus serão obrigados a coletar e dar destinação final de forma ambientalmente correta para os produtos que colocam no mercado. Pela proposta, o Ibama ficará responsável pela aplicação da resolução, podendo punir os infratores com base na Lei de 
Crimes Ambientais. O Apêndice 1 apresenta a resolução do CONAMA relativa à disposição final dos pneus inservíveis.

Inicialmente, para cada quatro pneus novos fabricados no Brasil ou importados, os fabricantes e importadoras deverão reciclar/reutilizar um pneu inservível. A exigência em relação às quantidades de pneus que deverão ser reciclados/reutilizados aumenta a cada ano, até janeiro de 2005, quando, para cada quatro pneus novos fabricados no País ou importados, as empresas fabricantes e as importadoras deverão dar destinação final a cinco pneus inservíveis; para cada três pneus reformados importados, de qualquer tipo, as empresas importadoras deverão dar destinação final a quatro pneus inservíveis.

A Tabela 8 apresenta os prazos e quantidades para coleta e destinação finais a serem seguidas pelos fabricantes e importadores de pneus.

TABELA 8 - Prazos e quantidades de pneus a serem coletados de acordo com a resolução $\mathrm{N}^{0} 258$ do Conselho Nacional do Meio Ambiente.

\begin{tabular}{l|c|c|c|c}
\hline \multirow{2}{*}{ A partir de: } & \multicolumn{2}{|c|}{ Pneus Novos } & \multicolumn{2}{c}{ Pneus Usados } \\
\cline { 2 - 5 } & $\begin{array}{c}\text { Nacionais e } \\
\text { Importados }\end{array}$ & $\begin{array}{c}\text { Reciclar e/ou } \\
\text { Reutilizar }\end{array}$ & Importados & $\begin{array}{c}\text { Reciclar e/ou } \\
\text { Reutilizar }\end{array}$ \\
\hline Jan. 2002 & 4 & 1 & - & - \\
Jan. 2003 & 2 & 1 & - & - \\
Jan. 2004 & 1 & 1 & 4 & 5 \\
Jan. 2005 & 4 & 5 & 3 & 4 \\
\hline
\end{tabular}

A Resolução do CONAMA representa um importante avanço em termos de política ambiental. Entretanto, tem sido motivo de críticas, algumas comentadas nos próximos parágrafos. 
A Resolução não contempla as inúmeras possibilidades de tratamento dos resíduos, que deve privilegiar a minimização da geração dos pneus usados através de tecnologias que prolonguem seu tempo de vida útil, incentivar a reutilização e o recondicionamento dos pneus e sua reciclagem, reduzindo assim o volume de carcaças a serem dispostas.

Determina, como solução para os problemas relacionados aos pneus usados, a “destinação final ambientalmente adequada". No artigo 9º̣, proíbe a disposição em aterros, mar, rios, terrenos baldios e queima a céu aberto. Entretanto não define o que seja "destinação final ambientalmente adequada".

Diz o artigo 10: "Os fabricantes e os importadores poderão criar centrais de recepção de pneus inservíveis (...) para armazenamento temporário e posterior destinação final ambientalmente segura e adequada", sugerindo a possibilidade da simples estocagem em depósitos, o que já vem acontecendo em algumas cidades brasileiras. A Figura 13 ilustra a situação na cidade de Sorocaba-SP, onde uma grande quantidade de pneus foi armazenada em dois galpões da Prefeitura.
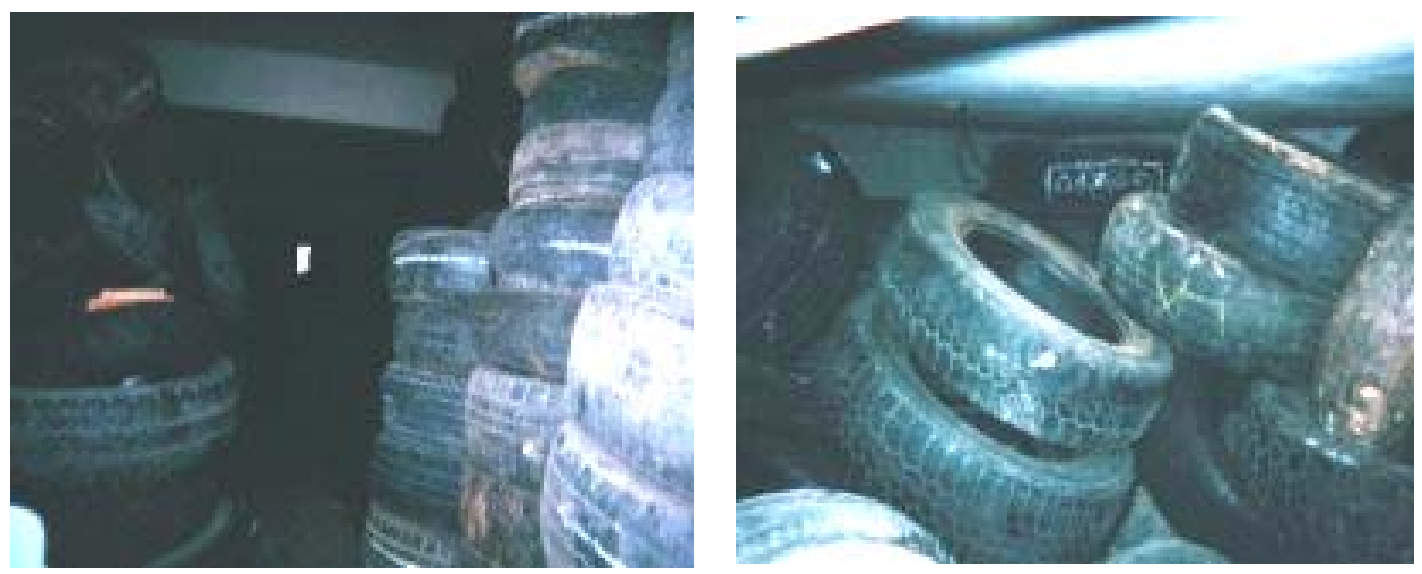

FIGURA 13 - Pneus armazenados em galpões da Prefeitura de Sorocaba-SP (fotos tiradas em abril de 1999). 
Pneus estocados em depósitos ou a céu aberto representam risco constante de incêndio. A Figura 14 ilustra um incêndio ocorrido em setembro de 1999, numa cidade do estado da Califórnia, EUA. Calcula-se entre seis e oito milhões o número de pneus queimados, causando prejuízos incalculáveis ao meio ambiente (CARLSON \& ZHU, 1999).

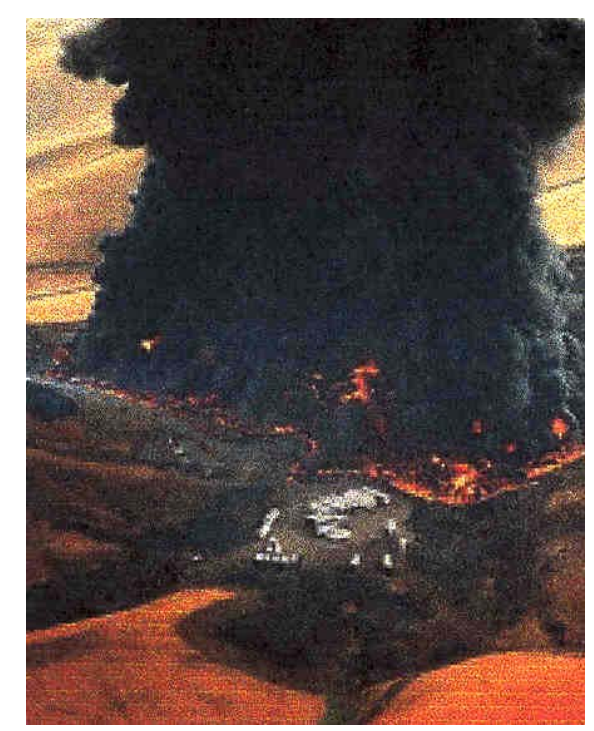

FIGURA 14 - Incêndio de 6 a 8 milhões de pneus ocorrido na Califórnia, EUA, em 1999 (CARLSON \& ZHU, 1999).

Os prazos e quantidades para coleta e destinação final estipulados no artigo $3^{0}$ proporcionam um aumento significativo do passivo ambiental existente, cuja redução começará somente a partir de 2005. Diz o artigo 11: "Os distribuidores, os revendedores e os consumidores finais de pneus, em articulação com os fabricantes, importadores e Poder Público, deverão colaborar na adoção de procedimentos, visando implementar a coleta dos pneus inservíveis existentes no País". O texto sugere que o passivo ambiental dos fabricantes poderia estar sendo dividido com a sociedade e o Poder Público, não estabelecendo claramente o "princípio do berço ao túmulo" onde o setor produtivo é responsável pelo seu produto, da criação até seu descarte. 
Existem vários projetos de lei em tramitação no Congresso Nacional que tratam das questões relativas ao problema dos pneus inservíveis, entre os quais pode-se destacar: o PL 1259/95 (do Sr. Pedro Novaes), que trata da reciclagem de pneus inservíveis, independentes de sua origem (importado ou produzido no Brasil); o PL 2949/97 (do Sr. Eduardo Jorge) que dispõe sobre a obrigatoriedade de reciclagem dos materiais plásticos, metálicos e borracha utilizados na fabricação de automóveis e outros veículos automotores; o PL 1677/99 (do Sr. Ronaldo Vasconcelos) que trata da destinação dos pneus usados; o PL 03578/00 (do Sr. Pedro Pedrossian Filho) que ratifica o conteúdo da Resolução 258 e dá outras providências.

O projeto de lei 3029/97 institui uma Política Nacional de Resíduos e propõe a criação de um Sistema Nacional de Resíduos (SISNARES), que disciplinará os tratamentos e as disposições finais dos resíduos. Neste projeto estão incluídos os seguintes princípios de gestão de resíduos:

- Princípio do poluidor-pagador, onde o gerador dos resíduos responde pelo custo do manejo, tratamento e destino final do seu resíduo;

- Princípio do berço ao túmulo, onde a indústria passa a ser responsável pelo seu produto até o fim do ciclo de sua vida útil;

- Princípio da co-responsabilidade, onde as indústrias poderão transferir parte da responsabilidade por eventuais danos ambientais causados pela coleta, tratamento ou disposição final inadequada a outras empresas contratadas para realizar esses serviços;

- Princípio do direito ao saber do cidadão, possibilitando o acesso às informações de interesse da coletividade, referentes aos resíduos gerados no processo produtivo; 
- Princípio dos 3Rs: Reduzir, Reutilizar e Reciclar. Esse princípio busca minimizar a geração de resíduos, através da mudança do padrão de produção: de linear insustentável para circular sustentável. No processo produtivo, a escolha das matérias-primas deverá ser feita baseada na análise do ciclo de vida útil dos materiais.

Uma das propostas da Política Nacional de Resíduos, em tramitação no Congresso Nacional, refere-se à criação da figura de empresa exclusivamente recicladora, que contará com isenção de impostos como IPI e ICMS. São consideradas empresas exclusivamente recicladoras aquelas constituídas com o propósito de operar exclusivamente com matéria-prima destinada à reciclagem, cujo produto final constitua-se em produto acabado ou intermediário. O objetivo é acabar com a bitributação dos produtos reciclados, que já pagaram impostos quando produzidos pela primeira vez.

Em São Paulo, a Secretaria Estadual do Meio Ambiente elaborou um projeto de lei com o objetivo de estabelecer uma Política Estadual de Resíduos Sólidos que busca, prioritariamente, reduzir a geração de resíduos na fonte. Fabricantes ou importadores de produtos que, depois de consumidos, resultam em grandes quantidades de resíduos ou em resíduos perigosos poderão ser responsabilizados pela coleta, tratamento e destinação final desses resíduos. Fabricantes de pneus, por exemplo, poderão ser responsabilizados por eventuais danos causados ao ambiente pela má destinação dos resíduos do uso de seus produtos.

O projeto de lei foi publicado no Diário Oficial do dia 01/04/98. A proposta introduz os conceitos de responsabilização pós-consumo do produtor, do princípio poluidor-pagador e considera o direito do consumidor à informação sobre o potencial de degradação ambiental dos produtos e serviços. 
Diz o artigo 69: "O gerador de resíduos sólidos (...) responde civilmente pelos danos ambientais, (...) decorrentes de sua atividade, cabendo-lhe (...) a prevenção, recuperação ou remediação (...) ou, em caso disso não ocorrer, cabe-lhe ressarcir, integralmente, todas as despesas realizadas pela administração pública para a devida reparação do dano ambiental".

O projeto de lei determina ainda a obrigatoriedade de os municípios elaborarem planos de gerenciamento com soluções específicas para cinco tipos de resíduos: urbanos, industriais, de serviços de transporte, de serviços de saúde e hospitalares e especiais (pneus, embalagens de agrotóxicos, medicamentos, pilhas, lâmpadas fluorescentes, óleos para motores e outros materiais tóxicos).

Nenhum município poderá decidir sobre o armazenamento ou a destinação final de seu lixo sem que os projetos específicos tenham sido aprovados pelo órgão ambiental estadual competente, que fica responsável também pela fiscalização desses serviços.

O projeto prevê incentivo fiscal e financeiro às instituições públicas e privadas que promovam a minimização dos resíduos mediante prevenção da geração, reutilização e reciclagem, assim como àquelas que invistam na pesquisa de tecnologias limpas.

\subsubsection{1 - Algumas Considerações sobre as Importações de Pneus Usados}

A abertura do mercado brasileiro, em 1990, possibilitou a melhoria da qualidade e a redução dos preços dos produtos aqui produzidos, devido à concorrência dos produtos importados. Entretanto, também permitiu as importações de pneus usados, também chamados de pneus "meia-vida" ou 
"semi-novos", vindos principalmente dos Estados Unidos, Japão e países europeus. A partir daquele momento, considerou-se a hipótese de que os países exportadores poderiam estar transferindo seus resíduos para o Brasil, pois são países que possuem elevado descarte anual e normalmente contam com severa legislação ambiental. Para esses países, a exportação dos pneus usados é muito interessante do ponto de vista ambiental, pois transferem parte de seu problema ambiental para outros países onde não existe legislação que aborda especificamente essa questão.

Os próximos itens apresentam um resumo das Portarias, Decretos, Resoluções e Projetos de Lei referentes à importação de pneumáticos usados:

- Portaria DECEX nํำ 08 de 13/05/91

Art. 27 - Proíbe a importação de bens de consumo usados.

- Portaria DECEX ño 01 de 09/01/92

Permite a importação de pneumáticos (carcaças) usados pelas empresas de recauchutagem no país.

- Portaria DECEX n⿳ำ 18 de 13/07/92

Art. $1^{\underline{o}}$ - Revoga a Portaria DECEX n⿳ำ 01 de 09/01/92;

Art. $2^{\underline{0}}$ - As importações de pneumáticos usados ficam sujeitas ao Art. 27 da Portaria DECEX no 08 de 13/05/91.

- Portaria Normativa do IBAMA n⿳0 138 de 22/12/92

Art. $2^{\underline{o}}, \S 3^{\mathrm{o}}$, inciso III - Destaca os pneumáticos usados (pneus meia-vida) como resíduos, cuja importação é proibida.

- Decreto Legislativo no 34 de 16/06/92

Aprova o texto da Convenção sobre o Controle de Movimentos Transfronteiriços de Resíduos Perigosos e sua Eliminação, concluída em Basiléia, Suíça, em 22/03/89. 
- Decreto Legislativo $n^{0}$ 875, sancionado pelo Presidente Itamar Franco em 22/07/93 - Promulga o texto da Convenção de Basiléia, cujo princípio determina que a destinação final do resíduo deve ser feita no local ou o mais próximo possível da geração do mesmo, por tratar-se de um resíduo inconveniente que, contando com disposição final inadequada, pode trazer sérios prejuízos ao meio ambiente e à saúde da população.

- Súmula $\mathrm{n}^{\mathrm{o}} 19$ de 15/12/93 - Diário da Justiça $\mathrm{n}^{\mathrm{o}} 238$ (aprovado pelo

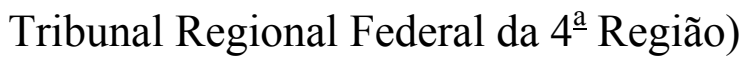

Legitima a restrição imposta pela Portaria DECEX n⿳ำ 08 de 13/05/91.

- Resolução CONAMA no 7 de 04/05/94

Art. $2^{\circ}$ - proíbe a importação de resíduos perigosos para qualquer fim.

- Resolução CONAMA nº 37 de 30/12/94

Art. $5^{\circ}, \S 2^{\underline{o}}$ - Permite a importação de resíduos para reaproveitamento ou reciclagem por terceiros;

Art. 12 - Torna sem efeito a Portaria IBAMA n⿳0 138-N e revoga a Resolução CONAMA nº 7 de 04/05/94.

- Projeto de Lei $\mathrm{n}^{\mathrm{o}}$ 4.109/93 (retirado do Congresso pelo Poder Executivo em setembro de 1995)

Aprovado com um substitutivo que mantém as importações de pneumáticos usados, com restrições e exigências, entre elas a garantia de quilometragem e obrigação de reciclagem, estendendo tais exigências aos fabricantes.

- O Ministério da Fazenda e o Ministério da Indústria, do Comércio e do Turismo publicaram, em 12/09/95, a Portaria Interministerial $\mathrm{n}^{\mathrm{o}}$ 03, proibindo a importação de bens de consumo usados, exceto aqueles doados a hospitais, casas de saúde e entidades assistenciais.

- Projeto de Lei n⿳⺈ 1.259/95, de 28/11/95 (de autoria do Sr. Pedro Novais)

Dispõe sobre a reciclagem de pneus inservíveis, independentes de sua origem - importado ou produzido no Brasil. 
- Em 20/01/97, revogando a Resolução no 37/94, foi publicada a Resolução CONAMA n⿳ำ 23/96, proibindo a importação de pneumáticos usados.

- Decreto $\mathrm{n}^{\mathrm{o}} 3919$, de 14 de setembro de 2001 - acrescenta artigo ao Decreto $\mathrm{n}^{\mathrm{o}} 3.179$, de 21 de setembro de 1999, que dispõe sobre a especificação das sanções aplicáveis às condutas e atividades lesivas ao meio ambiente:

Art. 47-A - Importar pneu usado ou reformado: Multa de R\$400,00 (quatrocentos reais), por unidade. Parágrafo único: Incorre na mesma pena, quem comercializa, transporta, armazena, guarda ou mantém em depósito pneu usado ou reformado, importado nessas condições.

Atualmente, a importação de pneu usado não é permitida pela legislação brasileira por dois instrumentos legais: a Portaria Interministerial $\mathrm{n}^{\mathrm{o}} 03$, de 12/09/95, que proíbe a importação de bens de consumo usados e a Resolução do CONAMA 23/96. O Decreto 3919/2001 estabelece multas para quem importa e comercializa pneus usados. Apesar disso, as importações de carcaças de pneus continuam sendo realizadas através de liminares e mandatos de segurança. A Tabela 9 apresenta um resumo da importação de pneus usados no período entre 1995 e 1999 (TOMMASINI, 2000).

TABELA 9 - Importação de pneumáticos usados e recauchutados entre 1995 e 1999 (TOMMASINI, 2000).

\begin{tabular}{|c|c|c|c|c|c|c|c|c|}
\hline \multirow{2}{*}{ Ano } & \multicolumn{4}{|c|}{ Pneus Usados } & \multicolumn{4}{|c|}{ Pneus Recauchutados } \\
\hline & Qtd. & kg & US\$/un. & kg/un. & Qtd. & kg & US\$/un. & kg/un. \\
\hline 1995 & 3.147 & 23.835 & 0,88 & 7,57 & 440 & 3.868 & 7,32 & 8,78 \\
\hline 1996 & 6.128 & 21.546 & 0,34 & 3,52 & 965 & 8.515 & 5,51 & 8,82 \\
\hline 1997 & 1.747 & 10.956 & 0,58 & 6,27 & 2.393 & 20.012 & 4,34 & 8,36 \\
\hline 1998 & 950 & 6.414 & 0,63 & 6,75 & 3.383 & 27.572 & 4,39 & 8,15 \\
\hline 1999 & 1.207 & 10.027 & 0,73 & 8,31 & 2.023 & 18.455 & 4,98 & 9,12 \\
\hline Total & 13.179 & 72.778 & - & - & 8.764 & 78.422 & - & - \\
\hline
\end{tabular}




\subsubsection{2 - Destinação Final dos Pneus: Propostas dos Importadores e Fabricantes}

A Associação Brasileira de Importadores de Pneus (ABIP) têm se manifestado no sentido favorável à aprovação de leis que responsabilizam fabricantes e importadores de pneumáticos pelo destino final dado aos resíduos de seu produto. A $\mathrm{ABIP}$ se propõe a reciclar o mesmo número de pneus que irá importar, tendo como propostas:

- A construção de usinas para reciclar pneus usados utilizando a tecnologia Relastomer $^{\circledR}$ (ABIP, 1996);

- A extração de óleo combustível dos pneus usados simultaneamente ao processamento de xisto. A tecnologia foi desenvolvida pela Unidade de Negócios da Industrialização do Xisto da Petrobrás, localizada em São Mateus do Sul, no Paraná (BARBOSA, 2002).

A tecnologia Relastomer ${ }^{\circledR}$ foi desenvolvida no Brasil pelo pesquisador Luiz Carlos Oliveira da Cunha Lima e patenteada nos Estados Unidos e Europa. Trata-se de um processo químico que garante o aproveitamento e a reciclagem total dos pneus.

Os pneus descartados são recolhidos e cortados em pequenos pedaços. Em seguida são colocados em um tanque com solvente, que torna a borracha quebradiça. Ela passa, então, por um processo de pressão, em que a borracha se desprende da malha de aço e do tecido. Um sistema de peneiras e imãs separa a borracha, o tecido e o aço. A borracha triturada vai para um reator, onde passa por um processo que recupera $75 \%$ de suas características originais. A borracha segue para um tanque de secagem, onde o solvente é totalmente recuperado, retornando para o tanque do início do processo. 
A borracha regenerada pode ser utilizada em compostos destinados a produtos com menor exigência quanto ao desempenho, tais como tapetes para automóveis, sinalizadores de trânsito, isolantes acústicos, solados, pneus industriais e de bicicletas, além de pisos esportivos, residenciais e industriais, entre outros.

Outro projeto inédito foi desenvolvido em parceria com a Unidade de Negócios da Industrialização do Xisto da Petrobrás (antiga Superintendência Industrial do Xisto - SIX), localizada em São Mateus do Sul, no Paraná. Tratase da extração de combustível de pneus simultaneamente ao processamento do xisto. A ABIP pretende organizar a coleta e fornecer os pneus triturados para o processamento combinado com a pedra. A borracha triturada na granulometria adequada sofre um processo de decomposição térmica (pirólise), liberando óleo, gás e enxofre. Cada tonelada de pneu produz $50 \%$ de óleo e $8 \%$ de gás (FIORI, 1998).

A empresa, que começou a operar em escala industrial no segundo semestre de 2001, tem capacidade para processar 27 milhões de pneus por ano, que seriam misturados às rochas do xisto betuminoso na proporção de $5 \%$. A SIX calcula em um milhão o número de pneus já reciclados em sua usina (BARBOSA, 2002).

Segundo a Associação Brasileira da Indústria de Pneumáticos (ANIP), a posição dos fabricantes em relação ao destino final dado aos resíduos de seu produto tem se concentrado em investimentos para realização de pesquisas através de suas matrizes localizadas no exterior. Para a ANIP, a solução para o problema dos pneus inservíveis no Brasil estaria na sua utilização como combustível em fornos de cimento (TOMMASINI, 2000). O Brasil possui 66 indústrias cimenteiras espalhadas pelo país e, dentre essas, está a Companhia 
de Cimento Ciminas S. A., localizada em Pedro Leopoldo-MG, que já utiliza pneus como combustível.

Um acordo firmado entre a ANIP e a Cimpor - Cimentos de Portugal, estabelece que os fabricantes irão recolher os pneus e entregá-los a custo zero nas unidades de reciclagem localizadas em Jundiaí-SP e Recife-PE. Nestas unidades serão instalados equipamentos para trituração com capacidade para processar até oito toneladas de pneus por hora. Os pneus triturados (pedaços com 2,5 cm de diâmetro) serão queimados nos fornos das seis fábricas de cimento que a Cimpor possui no Brasil, substituindo o carvão-coque importado da África do Sul. Segundo ROCHA FILHO (2001), a empresa já conta com as licenças ambientais necessárias para co-processar pneus em fornos de produção de clínquer. A Cimpor detém $9 \%$ do mercado de cimento nacional e opera cimenteiras no Rio Grande do Sul, Goiás, São Paulo, Bahia, Alagoas e Paraíba.

No que diz respeito à coleta dos pneus inservíveis, TOMMASINI (2001) destaca que a indústria brasileira de pneus dispõe de uma vasta rede de revendedores, com aproximadamente quatro mil pontos espalhados em todo o território nacional, que "poderão colaborar na coleta" conforme especifica o artigo 11 da Resolução n⿳o 258 do CONAMA.

\subsection{2 - Europa}

O conceito embutido nos projetos de lei que instituem políticas de resíduos e na Resolução do CONAMA de que "quem contamina paga" existe há anos em diversos países europeus. De acordo com as diretrizes da Comunidade Econômica Européia (CEE) em matéria de resíduos, não é do estado e nem 
dos municípios a responsabilidade de financiar a destinação dos resíduos, mas sim dos seus produtores e detentores.

A União Européia baseia a sua abordagem da gestão dos resíduos em princípios bem definidos (CE, 2000):

- Princípio da prevenção: é necessário minimizar e prevenir, sempre que possível, a produção de resíduos;

- Responsabilidade do produtor e princípio poluidor-pagador: quem produz os resíduos ou polui o ambiente deve pagar a totalidade dos custos de suas ações;

- Princípio da precaução: é necessário prever potenciais problemas;

- Princípio da proximidade: os resíduos devem ser eliminados o mais próximo possível do local onde são produzidos.

A União Européia estabelece também uma hierarquia preferencial das operações da gestão de resíduos: 1) prevenção dos resíduos; 2) reutilização e reciclagem; 3) otimização da eliminação final e melhoria da monitoração.

Não existe uma legislação específica sobre a gestão de pneus usados, embora três Diretivas da Comunidade Européia poderão influenciar no tratamento dos resíduos de pneus: a Diretiva 1999/31/CE sobre disposição de resíduos em aterros, a Diretiva 2000/53/CE sobre veículos em fim de vida e a Diretiva 2000/76/CE sobre incineração de resíduos.

A Diretiva 1999/31/CE do Conselho, de 26 de abril de 1999, relativa à disposição de resíduos em aterros, estabelece que devem ser tomadas medidas para que não sejam aceitos em aterros os pneus usados inteiros, a partir de 2003 (salvo algumas exceções), e pneus usados fragmentados, a partir de 2006. 
A Diretiva 2000/53/CE do Parlamento Europeu e do Conselho, de 18 de setembro de 2000, sobre veículos em fím de vida útil, prevê a instauração de um sistema de recolhimento dos veículos em fim de vida, a cargo do produtor. O objetivo prioritário da diretiva consiste na prevenção dos resíduos. Para esse efeito, a diretiva estabelece que os fabricantes, os fornecedores de materiais e de equipamentos devem:

- Reduzir a utilização de substâncias perigosas na fase de projeto dos veículos;

- Conceber e fabricar veículos que facilitem a sua desmontagem, reutilização, valorização e reciclagem quando fora de uso;

- Desenvolver a utilização de materiais reciclados na fabricação dos veículos;

- Tomar medidas para que os componentes dos veículos colocados no mercado após 1 de julho de 2003 não incluam mercúrio, cromo hexavalente, cádmio e chumbo (salvo algumas exceções).

O armazenamento e o tratamento dos veículos em fim de vida útil passará a estar submetido a um controle rigoroso. Os estabelecimentos ou as empresas que efetuam operações de tratamento devem desmantelar os veículos em fim de vida útil antes da operação de tratamento e recuperar todos os componentes prejudiciais ao ambiente. Segundo a proposta, deve ser privilegiada a reutilização e a reciclagem dos componentes dos veículos (baterias, pneumáticos, óleos).

O objetivo da Diretiva 2000/53/CE é aumentar a taxa de reutilização e de valorização até $85 \%$ em massa média por veículo até o ano 2006 e até 95\% em 2015, bem como aumentar a taxa de reutilização e de reciclagem, nos mesmos prazos, até um mínimo de $80 \%$ e $85 \%$, respectivamente, em massa média por veículo e por ano. 
A Diretiva 2000/76/CE, do Parlamento Europeu e do Conselho, de 04 de dezembro de 2000, relativa à incineração de resíduos, estabelece valoreslimite de emissões mais rigorosos para as instalações novas e existentes e é aplicável igualmente aos chamados co-incineradores, com disposições especiais para os fornos de cimento.

\subsection{3 - Estados Unidos}

Nos Estados Unidos, os riscos ambientais vinculados à presença de pneus inservíveis motivaram a criação de legislação específica em nível federal e estadual. Cerca de 48 estados apresentam leis para controlar a disposição das carcaças de pneus. As leis estaduais regulamentam a aquisição, armazenagem e processamento dos pneus, impõem restrições para armazenagem em aterros sanitários e oferecem incentivos para o desenvolvimento de novas alternativas de uso (EPA, 1999).

Muitos estados americanos proíbem a disposição de pneus inteiros em aterros, só os recebendo triturados e mesmo assim cobrando taxas tão elevadas que tornam essa alternativa economicamente proibitiva. Nos estados onde é permitido estocar pneus sem enterrá-los, existem normas que regulamentam o tamanho, a construção de obras de prevenção a incêndios, coberturas e tapumes para que haja o controle adequado desses depósitos.

A Tabela 10 apresenta um resumo da situação da disposição de pneus em aterros sanitários nos Estados Unidos. 
TABELA 10 - Panorama da disposição de pneus usados nos Estados Unidos (RMA, 2000).

\begin{tabular}{lc}
\hline Situação nos EUA em 2000 & \\
\hline Número de pneus descartados & 273 milhões \\
Número de pneus em depósitos & 300 milhões \\
Estados com legislação/regulamentação sobre pneus usados & 48 \\
Estados que proíbem a disposição de pneus inteiros nos aterros & 33 \\
Estados que baniram completamente os pneus dos aterros & 12 \\
Estados sem qualquer restrição quanto ao envio de pneus aos aterros & 5 \\
Estados que permitem depósitos de pneus & 7 \\
\hline
\end{tabular}

Cerca de 27 estados americanos cobram taxas sobre a venda de pneus novos e 3 estados impõem taxas no momento da transferência de veículos automotores ou no momento em que o veículo é registrado. As taxas são depositadas em um fundo para financiar programas de educação, empréstimos ou subvenções, projetos para reciclagem e/ou eliminação dos depósitos de pneus. As taxas variam entre US\$ 0,25 e US\$2,00 por pneu (EPA, 1999).

Em nível federal, a seção 1038 da Lei sobre a Eficiência do Transporte Intermodal de Superfície, de 1991 (Intermodal Surface Transportation Efficiency Act - ISTEA, 1991), que trata do "uso de material reciclado em pavimentação", estabelecia na subsecção (d) a obrigatoriedade da utilização de um percentual mínimo de borracha reciclada nas misturas asfálticas (em relação ao total produzido), iniciando com 5\% em 1994 até 20\% em 1997, e assim mantido nos anos seguintes. A lei garantia incentivos fiscais aos estados que utilizassem borracha de pneus nas misturas asfálticas e previa punições aos estados que não a obedecesse. 
A indústria da pavimentação se opôs vigorosamente à legislação. Na época, a maioria das técnicas disponíveis eram patenteadas e existiam processos em andamento para estender a validade das patentes que haviam expirado. A indústria tradicional não queria perder uma parcela significativa do mercado para poucos empreiteiros que detinham a tecnologia. Como parte da campanha contra a utilização de misturas com borracha, foram levantados inúmeros questionamentos a respeito da emissão de poluentes nas usinas, da viabilidade econômica, da durabilidade e possibilidade de reciclagem desses pavimentos.

O lobby das empreiteiras foi extremamente eficiente para persuadir o Congresso a repelir a legislação vigente. Em 1995, o Congresso americano determinou a suspensão da Seção 1038, eliminando a obrigatoriedade dos estados referente à utilização de borracha nas misturas asfálticas e todas as penalidades associadas (CARLSON \& ZHU, 1999).

Durante a vigência da lei, pesquisadores e empresários americanos começaram a se interessar pelo aprimoramento das tecnologias existentes e disponíveis de adição de borracha triturada em materiais asfálticos. Novas tecnologias surgiram desde então, prevendo um mercado potencial para a reciclagem desse tipo de resíduo.

Entretanto, é preciso destacar que muitos pavimentos construídos com borracha não apresentaram desempenho satisfatório, gerando muita desconfiança por parte das administrações públicas. Logo, é fundamental que haja um constante aperfeiçoamento das técnicas disponíveis e pesquisas para o desenvolvimento de novos ensaios e especificações para misturas que contém borracha triturada de pneus. 


\section{3 - Misturas ASFÁlticas}

\section{1 - INTRODUÇão}

Uma mistura asfáltica para pavimentação pode ser definida como o produto resultante da mistura de materiais granulares (de graúdo a fino), de material de enchimento (fíler) e de ligante asfáltico, em proporções convenientemente estabelecidas e adequadas ao fim a que se destina.

No pavimento, o ligante atua como um agente aglutinante, proporcionando íntima ligação entre agregados de modo a resistir à ação mecânica de desagregação produzida pelas cargas do tráfego. Também atua como impermeabilizante, garantindo ao pavimento resistência à ação da água. Já os agregados minerais, quando unidos pelo ligante asfáltico, conferem resistência mecânica e flexibilidade à camada de rolamento. Como as misturas asfálticas contêm ligante asfáltico e agregados minerais, o comportamento da mistura é influenciado pelas propriedades de cada componente e no modo como eles interagem entre si na estrutura do pavimento.

\section{2 - Ligante ASFÁltico}

A característica mais importante de um ligante asfáltico é sua suscetibilidade térmica. A temperatura atua como um fator fundamental no comportamento 
desses materiais, visto que pode alterar seu estado físico ou de consistência. O comportamento dos cimentos asfálticos também depende do tempo de aplicação de carga. Um asfalto submetido a um mesmo carregamento aplicado com diferentes durações, apresentará diferentes comportamentos. Por esta razão, os ensaios de caracterização de materiais asfálticos devem respeitar valores especificados para temperatura e tempo de aplicação de carga.

O cimento asfáltico pode ser considerado um material viscoelástico, por apresentar comportamento elástico e viscoso simultaneamente, quando submetido a temperaturas intermediárias. Em altas temperaturas (acima de $100^{\circ} \mathrm{C}$ ), o cimento asfáltico atua como um fluído viscoso. Em baixas temperaturas (abaixo de $0^{\circ} \mathrm{C}$ ), o cimento asfáltico torna-se um sólido elástico: quando recebe um carregamento, o material se deforma; quando o carregamento é retirado, o material volta ao estado original.

Durante os serviços de pavimentação, os cimentos asfálticos devem apresentar as seguintes características:

- devem tornar-se suficientemente líquidos para facilitar a misturação com os agregados pétreos e o lançamento na pista;

- após o lançamento, devem tornar-se suficientemente sólidos para permitir que as camadas asfálticas de pavimentação resistam às ações das cargas do tráfego, mesmo sob altas temperaturas, sem sofrerem deformações excessivas ou prematuras;

- sob baixas temperaturas, devem possuir flexibilidade suficiente para impedir a desintegração e/ou o aparecimento de trincas nas camadas asfálticas.

Conforme destaca HUBER (1999), o comportamento elástico, viscoso e viscoelástico das camadas de concreto asfáltico depende da temperatura, do 
tempo de carregamento e das características reológicas do ligante asfáltico, além de propriedades dos agregados, que serão posteriormente discutidas.

Outra característica importante dos cimentos asfálticos diz respeito ao envelhecimento, que se inicia durante a fase de preparação da mistura, quando o cimento asfáltico é aquecido para facilitar os trabalhos de misturação com os agregados pétreos, que também são aquecidos. Durante essa fase, ocorrem alterações significativas nas propriedades reológicas do ligante, como a diminuição da penetração (ou aumento da consistência) e o aumento da viscosidade.

O envelhecimento de curto prazo é causado, principalmente, devido à perda dos componentes voláteis e oxidação durante a fase de construção. Acredita-se que o envelhecimento de longo prazo seja conseqüência da progressiva oxidação durante a vida em serviço do pavimento. Embora, em geral, o envelhecimento possa resultar no enrijecimento da mistura, o que pode ser benéfico do ponto de vista da distribuição das cargas e da deformação permanente, poderá também resultar num pavimento com tendências ao trincamento e desintegração e na perda de durabilidade em termos de resistência ao desgaste e suscetibilidade à umidade (LIANG \& LEE, 1996).

Os ensaios tradicionais mais importantes de controle laboratorial, recomendados pelas normas brasileiras para a certificação da qualidade dos materiais asfálticos, são:

- Método de Penetração de Materiais Betuminosos (ABNT/NBR 6576);

- Determinação do Ponto de Fulgor (ABNT/NBR 11341);

- Determinação do Ponto de Amolecimento de Materiais Betuminosos (Método do Anel e Bola - ABNT/MB-164/1972; ASTM/D-36);

- Método de Determinação da Viscosidade Saybolt-Furol (ABNT/MB-517);

- Ductilidade (ABNT/NBR 6293). 
Em função das limitações dos ensaios empíricos tradicionais, o Programa SHRP (Strategic Highway Research Program) iniciou, em 1987, o desenvolvimento de um sistema para especificar materiais betuminosos e misturas asfálticas com base em propriedades diretamente relacionadas ao desempenho dos pavimentos quando em serviço. O produto final desse programa de pesquisa foi denominado SUPERPAVE ${ }^{\circledR}$ ( $\underline{\text { Superior } \text { Performing }}$ Asphalt Pavements).

As especificações SUPERPAVE ${ }^{\circledR}$ não consideram os ensaios tradicionais de classificação de ligantes (penetração e viscosidade), visto que esses sistemas de classificação não possuem relação direta com o comportamento dos asfaltos em serviço. Propõem, para cada zona climática, temperaturas máximas e mínimas de projeto. As temperaturas máximas de projeto classificam o ligante (Performance Grade - PG) e servem para garantir resistência à deformação permanente, enquanto que as mínimas são utilizadas na subclassificação dos ligantes (Subclasse PG) e garantem a resistência à formação de trincas a baixas temperaturas.

Outra característica importante relacionada à avaliação do ligante no sistema SUPERPAVE $^{\circledR}$ é que as propriedades físicas também são obtidas em ligantes envelhecidos. As especificações incluem dois procedimentos para simular o envelhecimento durante as operações de produção (mistura em usina) e aplicação (lançamento e compactação) da mistura e também o que ocorre durante a vida em serviço. O envelhecimento durante a produção e aplicação da mistura é simulado em laboratório através de ensaio de rotação de filme fino em estufa (RTFOT). O envelhecimento durante a vida em serviço é simulado em laboratório pelo ensaio de envelhecimento em vaso pressurizado (PAV), onde amostras de ligante são expostas ao calor e à pressão. 
As propriedades físicas dos ligantes são obtidas através de quatro equipamentos (FHWA, 1995):

- Reômetro de cisalhamento dinâmico (DSR - Dynamic Shear Rheometer);

- Viscosímetro rotacional (Rotational Viscosimeter);

- Reômetro de viga à flexão (BBR - Bending Beam Rheometer);

- Prensa de tração direta (DDT - Direct Tension Tester).

O reômetro de cisalhamento dinâmico (DSR) é utilizado para caracterizar as propriedades viscoelásticas de ligantes asfálticos virgens ou envelhecidos, através da medida do módulo de cisalhamento complexo $\left(\mathrm{G}^{*}\right)$ e do ângulo de fase $(\delta)$.

$\mathrm{O} \mathrm{G}^{*}$ é um indicador da rigidez ou resistência do ligante asfáltico ao acúmulo de deformação permanente sob as cargas do tráfego (tensões repetidas de cisalhamento). $\mathrm{O} \delta$, definido como o intervalo de tempo entre a aplicação da tensão cisalhante e a deformação cisalhante resultante, é um indicador da quantidade relativa de deformações recuperáveis e não recuperáveis.

Para materiais perfeitamente elásticos, o carregamento aplicado coincide com a resposta imediata da deformação, e o intervalo de tempo é zero. Um material totalmente viscoso apresenta um intervalo de tempo entre o carregamento e a resposta, levando a um ângulo de fase que se aproxima de $90^{\circ}$. Os materiais viscoelásticos, como os ligantes asfálticos, apresentam o ângulo de fase variando entre $0^{\circ}$ (baixa temperatura) e $90^{\circ}$ (alta temperatura). Para controlar a rigidez do ligante, a especificação utiliza o parâmetro $\underline{\mathrm{G}^{*} / \operatorname{sen} \delta}$ para altas temperaturas $\left(>46^{\circ} \mathrm{C}\right)$ e $\underline{\mathrm{G}^{*} \operatorname{sen} \delta}$ para temperaturas intermediárias (entre $7^{\circ} \mathrm{C}$ e $\left.34^{\circ} \mathrm{C}\right)$. 
A altas temperaturas, a rigidez $\left(\mathrm{G}^{*} / \mathrm{sen} \delta\right)$ de um ligante não envelhecido deve ser superior a 1,0 kPa. Para amostras submetidas ao envelhecimento de curto prazo (RTFOT), a rigidez deverá ser de no mínimo 2,2 kPa. Para temperaturas intermediárias, o ensaio é realizado utilizando-se amostras submetidas ao envelhecimento de longo prazo (PAV), sendo fixados valores máximos de rigidez $\left(\mathrm{G}^{*} \operatorname{sen} \delta<5.000 \mathrm{kPa}\right)$ para assegurar que o ligante não irá contribuir para o aparecimento de trincas por fadiga.

O viscosímetro rotacional (Rotational Viscosimeter) é utilizado para avaliar a trabalhabilidade dos ligantes asfálticos em alta temperatura. $\mathrm{O}$ equipamento (viscosímetro Brookfield) mede a viscosidade através do torque necessário para rodar uma haste imersa em uma amostra de asfalto quente, a velocidade constante. Geralmente, a caracterização da rigidez do ligante é feita a $135^{\circ} \mathrm{C}$, quando este age quase que inteiramente como um fluido viscoso. A medida da viscosidade busca assegurar que o ligante será suficientemente fluido para ser bombeado e misturado com os agregados.

O reômetro de viga à flexão (BBR - Bending Beam Rheometer) é utilizado para caracterizar a rigidez do ligante asfáltico a baixa temperatura. $\mathrm{O}$ equipamento mede a deflexão produzida quando uma carga é aplicada no ponto médio de uma viga de ligante betuminoso simplesmente apoiada, durante 240 segundos. No ensaio são utilizados ligantes submetidos ao envelhecimento de longo prazo (PAV).

A viga a ser ensaiada é colocada em um banho com temperatura controlada e determinada em função do clima da região onde será construído o pavimento. A carga de ensaio e a deflexão no ponto médio da viga são monitoradas ao longo do tempo. A rigidez $\underline{\mathrm{S}}$ (creep stiffness) e o módulo de relaxação $\underline{\mathrm{m}}$ (creep rate) são calculados a partir da resposta ao carregamento aplicado. 
A especificação recomenda um valor máximo de $300 \mathrm{MPa}$ para a rigidez $\underline{\mathrm{S}} \mathrm{e}$ um valor mínimo de 0,300 para a relaxação $\underline{\mathrm{m}}$, ambos calculados para um tempo de aplicação de carga de 60 segundos. Ligantes que possuem baixa rigidez não trincam em clima frio. Do mesmo modo, ligantes com alto valor de $\underline{m}$ são mais eficientes na dissipação das tensões durante a contração, minimizando a formação de trincas e fissuras.

Alguns ligantes podem exibir rigidez a baixa temperatura maior do que o desejado e, mesmo assim, podem não apresentar trincamento, devido à capacidade de deformar sem se romper. O ensaio de tração direta (DTTDirect Tension Tester) irá mostrar se o ligante asfáltico possui ductilidade suficiente a baixas temperaturas. $\mathrm{O}$ ensaio consiste em estirar uma amostra de ligante, em temperatura controlada, até seu rompimento. A deformação na ruptura deverá ser maior ou igual a $1 \%$. No ensaio são utilizadas amostras submetidas ao envelhecimento de longo prazo (PAV).

\section{3 - AgRegadoS}

Os agregados podem ser subdivididos em naturais ou artificiais. Os agregados naturais são aqueles encontrados em depósitos naturais superficiais, como os pedregulhos rolados (de cava ou de rio), as lateritas e as areias. Já os agregados artificiais são aqueles obtidos por meio de britagem de rocha (basalto, granito etc.) ou de seixos rolados.

Nos últimos anos, a preocupação crescente com os aspectos ambientais tem motivado a incorporação de agregados "especiais" nas misturas asfálticas. Este é o caso, por exemplo, das escórias de alto forno (resíduos industriais) e da borracha triturada de pneus inservíveis. 
Os agregados representam a maior parcela constituinte de um revestimento, chegando a valores superiores a $90 \%$ em peso do conjunto asfalto e agregado. Logo, as propriedades dos agregados utilizados nas misturas asfálticas preparadas a quente são muito importantes para o desempenho dos pavimentos.

Defeitos no pavimento, como desagregação e deformação permanente, podem estar diretamente relacionados à escolha inadequada dos agregados. Deste modo, é fundamental que os agregados possuam propriedades geométricas, fisico-químicas e mecânicas adequadas e que garantam o bom desempenho do pavimento.

Muitos dos ensaios atualmente em uso foram desenvolvidos para caracterizar os agregados empiricamente sem, necessariamente, possuírem uma sólida relação com o desempenho dos pavimentos quando em serviço. As normas brasileiras têm recomendado os seguintes ensaios para agregados pétreos:

- Resistência mecânica: Ensaio de Abrasão Los Angeles (DNER ME 35/98); Determinação do Índice de Tenacidade de Agregados pelo Aparelho Treton (IPT - ME 52); Resistência ao Esmagamento (DNER ME 197/97);

- Durabilidade: Ensaio de Sanidade (DNER ME 89/94);

- Forma: Índice de Forma (DNER ME 86/94);

- Adesividade a Ligante Asfáltico: Adesividade de Agregado Graúdo (DNER ME 78/94); Adesividade de Agregado Miúdo (DNER ME 79/94).

Durante as pesquisas do Programa SHRP não foram desenvolvidos novos ensaios e procedimentos para caracterizar os agregados pétreos; os ensaios já existentes foram aperfeiçoados e incorporados no sistema SUPERPAVE ${ }^{\circledR}$. Houve consenso entre os pesquisadores de que certas características dos agregados poderiam influenciar o bom desempenho dos pavimentos. Tais 
características, denominadas "propriedades de consenso", são: a) angularidade do agregado graúdo, b) angularidade do agregado miúdo, c) partículas achatadas e alongadas e d) teor de argila.

Também foram consideradas outras propriedades, denominadas "propriedades de origem", que apresentam menor influência direta no desempenho dos pavimentos. Essas propriedades permitem qualificar a procedência e verificar a aceitabilidade dos agregados. São elas: resistência ao desgaste (avaliada no ensaio de abrasão Los Angeles), sanidade (ensaio de sanidade em sulfato de sódio ou magnésio) e presença de materiais deletérios. Esses ensaios são comumente realizados nos organismos rodoviários brasileiros.

As especificações de angularidade dos agregados graúdos e miúdos possibilitam uma mistura asfáltica com alto grau de atrito interno e, portanto, com maior resistência ao cisalhamento e à deformação permanente. A limitação do número de partículas chatas e alongadas na mistura asfáltica garante que os agregados não serão tão suscetíveis ao esmagamento durante as fases de produção e construção e sob as cargas do tráfego. A fração argila, devido à sua expansividade, pode provocar o rompimento da película de ligante que envolve os agregados, dificultando a adesão entre as partículas.

As propriedades acima devem atender a padrões de exigência baseados no nível de tráfego e na espessura do pavimento: materiais próximos à superfície, submetidos a altos níveis de tráfego, devem obedecer a padrões mais rigorosos. A Tabela 11 (adaptada de SHRP, 1999) apresenta as especificações SUPERPAVE $^{\circledR}$ para as propriedades de consenso. É desejável que as propriedades sejam aplicadas na caracterização de toda a mistura de agregados e não somente nas partículas consideradas isoladamente. Nos Estados Unidos, essas propriedades têm sido aplicadas no controle de qualidade dos agregados utilizados nas misturas asfálticas. 
TABELA 11 - Critérios da especificação SUPERPAVE ${ }^{\circledR}$ para as propriedades de consenso (adaptada de SHRP, 1999).

\begin{tabular}{|c|c|c|c|c|c|c|}
\hline \multirow{2}{*}{$\begin{array}{c}\text { Tráfego } \\
\mathbf{N}^{(1)} \\
\text { (milhões) }\end{array}$} & \multicolumn{2}{|c|}{$\begin{array}{c}\text { Angularidade do } \\
\text { Agregado Graúdo } \\
\text { (\% mínima) }\end{array}$} & \multicolumn{2}{|c|}{$\begin{array}{l}\text { Angularidade do } \\
\text { Agregado Miúdo } \\
\text { (\% mínima) }\end{array}$} & \multirow{2}{*}{$\begin{array}{c}\text { Equivalente } \\
\text { de Areia } \\
\text { (\% mínima) }\end{array}$} & \multirow{2}{*}{$\begin{array}{l}\text { Partículas } \\
\text { Chatas e } \\
\text { Alongadas } \\
\text { (\% máxima) }\end{array}$} \\
\hline & $<100 \mathrm{~mm}$ & $>100 \mathrm{~mm}$ & $<100 \mathrm{~mm}$ & $>100 \mathrm{~mm}$ & & \\
\hline$<0,3$ & $55 /-$ & $-/-$ & - & - & 40 & - \\
\hline 0,3 até $<3$ & $75 /-$ & $50 /-$ & 40 & 40 & 45 & \multirow{4}{*}{10} \\
\hline 3 até $<10$ & $85 / 80^{(2)}$ & $60 /-$ & 45 & 40 & 45 & \\
\hline 10 até $<30$ & $95 / 90$ & $80 / 75$ & 45 & 40 & 45 & \\
\hline$\geq 30$ & $100 / 100$ & $100 / 100$ & 45 & 45 & 50 & \\
\hline
\end{tabular}

(1) Número equivalente de solicitações do eixo padrão (design ESAL's) para um período de 20 anos.

(2) " $85 / 80$ " significa que $85 \%$ dos agregados graúdos apresentam uma face fraturada e $80 \%$ apresentam duas ou mais faces fraturadas.

(3) Os critérios são apresentados como a porcentagem de volume de vazios em agregados finos não compactados.

(4) Critério baseado na razão 5:1 entre a máxima dimensão (comprimento) e a mínima dimensão (espessura).

\section{4 - Dosagem das Misturas Asfálticas}

O objetivo da dosagem é produzir uma mistura que possua trabalhabilidade satisfatória e a melhor combinação possível das seguintes propriedades: estabilidade (resistência às deformações permanentes), durabilidade (resistência à desagregação pela ação do tráfego e/ou do intemperismo), flexibilidade (resistência à flexão sob ação de carga repetida, sem que haja ocorrência de fissuras), impermeabilidade (resistência à penetração e percolação de água) e resistência ao atrito. 
Um bom projeto de mistura asfáltica deveria considerar os seguintes fatores que correspondem às principais causas de defeitos nos pavimentos: deformação permanente, trincas por fadiga, trincas a baixas temperaturas, além dos efeitos da umidade e do envelhecimento. Os próximos itens apresentam os métodos Marshall e SUPERPAVE ${ }^{\circledR}$ de dosagem de misturas betuminosas preparadas a quente.

\subsection{1 - Método Marshall}

O método Marshall foi concebido na década de 1930 por Bruce Marshall, engenheiro do Departamento Rodoviário do Estado do Mississipi. O método consiste na determinação da quantidade ótima de ligante a ser utilizado numa mistura betuminosa.

Anteriormente ao desenvolvimento do SUPERPAVE ${ }^{\circledR}$, aproximadamente $75 \%$ dos departamentos de estradas de rodagem dos Estados Unidos utilizavam alguma variação do Método Marshall enquanto que os $25 \%$ restantes utilizavam alguma variação do Método Hveem. No Brasil, o método Marshall é recomendado como critério quase que exclusivo na dosagem de misturas betuminosas para pavimentação.

No ensaio Marshall, a dosagem de misturas asfálticas é feita considerando-se valores admissíveis empíricos para a estabilidade e a fluência. Estabilidade pode ser definida como a capacidade da mistura em deformar-se (plasticamente) pouco sob a ação das cargas. Depende do tipo e das proporções dos materiais granulares, bem como do tipo e, principalmente, da quantidade de ligante betuminoso empregado. A fluência pode ser definida como a deformação sofrida pela mistura compactada quando submetida a uma tensão constante. 
$\mathrm{Na}$ dosagem das misturas asfálticas, o método Marshall considera os seguintes parâmetros:

- granulometria: busca-se a densidade máxima possível para garantir a máxima estabilidade;

- densidade aparente da mistura: calculada com os corpos-de-prova do ensaio de dosagem;

- densidade máxima teórica da mistura: densidade da mistura suposta sem vazios;

- porcentagem de vazios da mistura (Vv): volume total de pequenas bolsas de ar existentes entre as partículas de agregados recobertos por cimento asfáltico em uma mistura compactada em relação ao volume total da mistura;

- porcentagem de vazios do agregado mineral (VAM): porcentagem do volume do espaço intergranular de uma mistura asfáltica compactada, que inclui o volume de ar e de asfalto, em relação ao volume total da mistura;

- relação betume vazios (RBV): porcentagem do volume de VAM que é preenchido com cimento asfáltico;

- estabilidade: carga, em kgf, sob a qual o corpo-de-prova rompe quando submetido à compressão radial;

- fluência: deformação total, em décimos de milímetro ou centésimos de polegada, que o corpo-de-prova sofre ao romper.

Os métodos de ensaio do DNER (1995), DER-SP (1991) e ABNT (1993) fixam os procedimentos para o ensaio Marshall, que consiste basicamente nos seguinte passos: 
(a) Preparação dos corpos-de-prova. Na preparação dos corpos-de-prova para o ensaio, o agregado e o asfalto são aquecidos separadamente, até a temperatura especificada e, então, misturados. A mistura é colocada no molde aquecido e compactada com 50 ou 75 golpes em cada face do corpo-de-prova, com um soquete de $4,540 \mathrm{~kg}$, caindo de uma altura de 45,72 cm. Devem ser confeccionados um mínimo de 15 corpos-de-prova ( 3 para cada teor de asfalto), devendo estes ser moldados com cinco porcentagens de asfalto (em relação ao peso total da mistura), de modo a tornar possível a escolha do teor ótimo de asfalto.

(b) Método de Ensaio. O ensaio Marshall é executado com um corpo-de-prova cilíndrico de aproximadamente 4" (102 mm) de diâmetro e 21/2" $(6,35 \mathrm{~cm})$ de altura. Os corpos-de-prova são extraídos dos moldes e deixados em repouso, ao ar livre, durante 12 horas. São então pesados (ao ar e imersos em água) para a obtenção dos elementos necessários ao cálculo de suas características físicas. Os corpos-de-prova são imersos em banho de água a $60^{\circ} \mathrm{C}$, por um período de 30 a 40 minutos, após o qual são submetidos ao ensaio para determinação de suas características mecânicas (estabilidade e fluência).

(c) Curvas Típicas. Dos dados obtidos e calculados, são traçadas as curvas de variação da densidade, estabilidade, fluência, Vv e RBV, em função das porcentagens de ligante empregadas. A determinação do teor ótimo de ligante deverá atender aos limites, definidos em norma, para os valores dos parâmetros referidos acima.

Os limites recomendados pelo DER-SP (1991), DNER (1997) e ABNT (1993) para estabilidade $(\mathrm{E})$, fluência $(\mathrm{F})$, volume de vazios $(\mathrm{Vv})$ e relação betume vazios (RBV) encontram-se reproduzidos nas Tabelas 12, 13 e 14. 
TABELA 12 - Valores para estabilidade (E) e fluência (F) estabelecidos pelo DER-SP (1991).

\begin{tabular}{ccc}
\hline Tráfego & E (kgf) & F (0,01 pol) \\
\hline Médio & Mín. 500 & $8-16$ \\
Pesado & Mín. 750 & $8-16$ \\
\hline
\end{tabular}

TABELA 13 - Valores para estabilidade (E) e fluência (F) estabelecidos pelo DNER (1997) e ABNT (1993).

\begin{tabular}{lccc}
\hline Pressão dos Pneus & $\mathbf{n}^{\mathbf{0}}$ de Golpes & E (kgf) & F - 0,1 mm (0,01 pol) \\
\hline Até $7 \mathrm{kgf} / \mathrm{cm}^{2}$ & 50 & mín. 250 & $20-46(8-18)$ \\
De 7 a $14 \mathrm{kgf} / \mathrm{cm}^{2}$ & 75 & mín. 350 & $20-46(8-18)$ \\
\hline
\end{tabular}

TABELA 14 - Critérios estabelecidos pelo DER-SP (1991), DNER (1997) e ABNT (1993) para volume de vazios (Vv) e relação betume vazios $(\mathrm{RBV})$.

\begin{tabular}{lcccc}
\hline \multirow{2}{*}{ Tipo de Mistura } & \multicolumn{2}{c}{ Vv (\%) } & \multicolumn{2}{c}{ RBV (\%) } \\
& DER-SP & DNER/ABNT & DER - SP & DNER/ABNT \\
\hline Camada de rolamento & $3-5$ & $3-5$ & $75-85$ & $75-82$ \\
Camada intermediária & $4-10$ & $4-6$ & $60-72$ & $65-72$ \\
\hline
\end{tabular}

É importante reconhecer que o método Marshall não fornece as propriedades das misturas asfálticas compactadas que sejam relacionadas ao dimensionamento dos pavimentos ou ao desempenho no campo. $\mathrm{O}$ método visa apenas ajudar na escolha do teor ótimo de asfalto.

Os valores de estabilidade e fluência, obtidos no ensaio Marshall, podem não ter qualquer significado diante dos ligantes betuminosos atualmente em uso, 
da utilização de polímeros e outros materiais (recicláveis como borracha de pneus, por exemplo), das cargas do tráfego e de novas técnicas construtivas.

MOTTA et al. (1993) destacam que o método Marshall também apresenta diversidade de procedimentos na preparação das amostras, compactação e desmoldagem dos corpos-de-prova, sendo muito grande a dispersão dos resultados de estabilidade e fluência. SIDDIQUI et al. (1988) apontam como causas da variabilidade fatores como o tipo de soquete, a verticalidade da haste do soquete durante a operação de compactação dos corpos-de-prova, além de aspectos relativos ao "projeto" do soquete e à estrutura de fixação do molde e do soquete de compactação.

\subsection{2 - Método SUPERPAVE ${ }^{\circledR}$}

O método de dosagem SUPERPAVE ${ }^{\circledR}$ compreende as seguintes etapas (FHWA, 1995):
a) Seleção dos materiais;
b) Seleção da estrutura dos agregados (granulometria de projeto);
c) Seleção da quantidade de ligante;
d) Avaliação da suscetibilidade à umidade.

Geralmente os dois primeiros passos do processo consomem a maior parte do tempo de avaliação e irão controlar o desempenho da mistura a ser produzida. Quando comparado aos métodos tradicionais de dosagem, como o método Marshall, verificam-se as seguintes diferenças: o projetista obtém informações sobre a compacidade da mistura; o nível do esforço de compactação é vinculado aos níveis de tráfego; o envelhecimento a curto-prazo é utilizado em todos os corpos-de-prova submetidos à compactação giratória, de modo a simular o envelhecimento na fase pré-compactação. 


\section{a) Seleção dos Materiais}

A seleção dos materiais consiste na aceitabilidade de agregados minerais, ligantes asfálticos e modificadores que serão utilizados na mistura.

A especificação para ligantes (PG) é baseada no desempenho e na temperatura do pavimento, variando, portanto, com o clima da região em que será utilizado o ligante asfáltico. $\mathrm{O}$ grau de desempenho do ligante é um indicador das temperaturas extremas de projeto. Além das condições climáticas, o volume e a velocidade do tráfego também podem influenciar na seleção do ligante. Um pavimento sujeito a baixo movimento ou tráfego estacionário poderá requerer que o grau a alta temperatura seja elevado de 1 a 2 PGs. Pavimentos sujeitos a altos níveis de tráfego também podem requerer um aumento no grau do ligante a alta temperatura (por exemplo, passando-se de um PG 58-28 para um PG 6428). O ligante selecionado deverá ser submetido aos ensaios de caracterização e atender aos critérios especificados.

Os agregados devem ser submetidos aos ensaios para determinação das propriedades de consenso. A seleção da curva granulométrica (graduação) do agregado também faz parte do método de dosagem SUPERPAVE ${ }^{\circledR}$. Uma ferramenta útil nesta fase de análise é o gráfico de controle, onde o eixo vertical contém a porcentagem passando e o eixo horizontal contém uma escala numérica de tamanhos de peneira $(\mathrm{mm})$, elevados à potência de 0,45 .

A granulometria é baseada em quatro peneiras de controle:

- tamanho máximo do agregado;

- tamanho nominal máximo do agregado;

- $2,36 \mathrm{~mm}$

- $0,075 \mathrm{~mm}$. 
$\mathrm{Na}$ especificação da granulometria, são impostas restrições na graduação do agregado através dos pontos de controle e de uma zona de restrição. O menor e o maior valor requerido para as peneiras de controle mudam (assim como a zona de restrição) de acordo com a mudança do tamanho nominal máximo do agregado: 9,5 mm; $12,5 \mathrm{~mm} ; 19 \mathrm{~mm} ; 25 \mathrm{~mm}$ e $37,5 \mathrm{~mm}$. A Figura 15 ilustra os limites da especificação SUPERPAVE ${ }^{\circledR}$ para uma mistura que contém agregado de tamanho nominal máximo de 12,5 $\mathrm{mm}$.

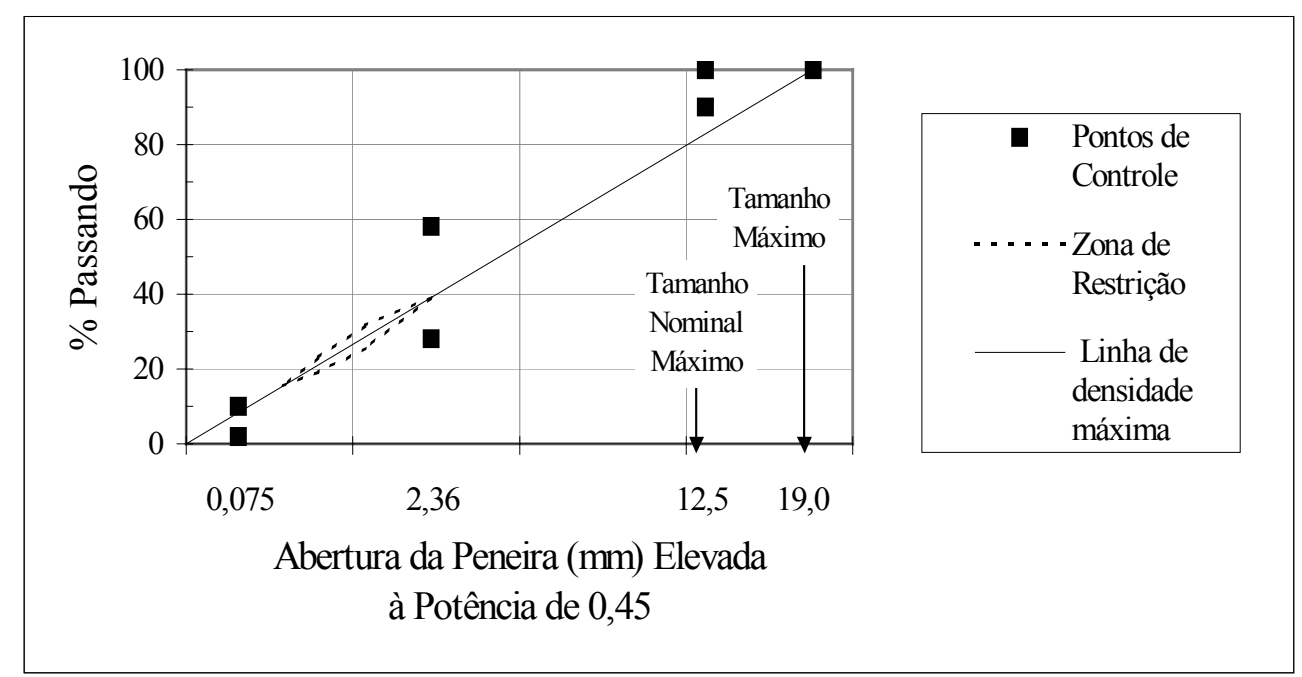

FIGURA 15 - Especificação SUPERPAVE ${ }^{\circledR}$ para mistura com agregado de tamanho nominal máximo de 12,5 mm (FHWA, 1995).

Deve-se evitar a granulometria de densidade máxima, onde os agregados se encaixam da forma mais compacta possível, contribuindo para que o espaço existente entre partículas não seja suficiente para permitir o adequado recobrimento de asfalto. A granulometria também deve evitar passar através da zona de restrição. Os pontos de controle, que acompanham a zona de restrição, são usados para controlar o formato da curva granulométrica. 
Resultados experimentais (MALLICK et al., 1998) indicam que a granulometria que passa através da zona de restrição apresenta problemas em algumas das propriedades da mistura compactada, principalmente na porcentagem de vazios no agregado mineral (VAM). Essa propriedade tem sido utilizada como um indicador da durabilidade da mistura e da resistência à deformação permanente.

A zona de restrição também serve para evitar curvas granulométricas que apresentam a chamada granulometria "corcunda". Estas curvas granulométricas estão geralmente associadas à presença de elevada porcentagem de areia fina na mistura. Logo, a zona de restrição tenta evitar o uso de alta porcentagem de areia, pois a presença excessiva desses agregados arredondados geralmente está associada a baixa resistência ao cisalhamento, sendo esta a principal causa de deformações permanentes nos pavimentos asfálticos.

\section{b) Seleção da Estrutura de Agregados}

Várias combinações de agregados (pelo menos três) devem ser avaliadas para a determinação da estrutura mais apropriada, ou seja, procura-se obter uma combinação de agregados que apresente propriedades adequadas de compactação e volumétricas. Após o estabelecimento das combinações de agregados, uma determinada quantidade de ligante é selecionada para cada combinação. A quantidade de ligante pode ser selecionada através de um procedimento preconizado no sistema SUPERPAVE ${ }^{\circledR}$ ou baseada na experiência do projetista.

O próximo passo consiste na avaliação das misturas experimentais pela compactação dos corpos-de-prova e determinação das propriedades 
volumétricas de cada mistura. Para prever o desempenho de um pavimento, é necessário um equipamento que simule em laboratório os efeitos do tráfego e a fase de construção (lançamento e compactação) no campo. Para tanto, o sistema SUPERPAVE ${ }^{\circledR}$ utiliza um equipamento denominado compactador giratório, amplamente analisado e aperfeiçoado durante o Programa SHRP. O ensaio tem por finalidade simular a massa específica, orientação dos agregados e características estruturais do revestimento após lançamento e compactação no campo.

A mistura envelhecida (curto prazo) é colocada em um molde cilíndrico de 150 milímetros de diâmetro. O molde é colocado no compactador e um sistema de carregamento mantém a pressão vertical constante sobre o corpode-prova, enquanto o molde é girado a uma velocidade de $30 \mathrm{rpm}$ com um ângulo de $1,25^{\circ}$ em relação à horizontal. É calculado o número de revoluções necessário a cada corpo-de-prova baseado no volume de tráfego previsto para o pavimento.

A Tabela 15 (adaptada de SHRP, 1999) apresenta as diretrizes do SUPERPAVE $^{\circledR}$ para a determinação do número de revoluções no ensaio de compactação giratória para diferentes níveis de tráfego (número equivalente de solicitações do eixo padrão).

TABELA 15 - Especificações SUPERPAVE ${ }^{\circledR}$ para determinação do número de revoluções (adaptada de SHRP, 1999).

\begin{tabular}{cccc}
\hline Tráfego $-\mathbf{N}^{*}$ & \multicolumn{3}{c}{ Parâmetros da Compactação Giratória } \\
\cline { 2 - 4 } (milhões) & $\mathbf{N}_{\text {inicial }}$ & $\mathbf{N}_{\text {projeto }}$ & $\mathbf{N}_{\text {máximo }}$ \\
\hline$<0,3$ & 6 & 50 & 75 \\
0,3 até $<3$ & 7 & 75 & 115 \\
3 até $<30$ & 8 & 100 & 160 \\
$\geq 30$ & 9 & 125 & 205 \\
\hline
\end{tabular}

*Número equivalente de solicitações do eixo padrão (design ESAL's) para um período de 20 anos. 
Registra-se a altura do corpo de prova após cada revolução, calculando-se o volume. A massa da mistura e o volume permitem a determinação da massa específica do corpo-de-prova $\left(\mathrm{G}_{\mathrm{mb} \text {, estimado }}\right)$. Este cálculo admite que o corpode-prova é um cilindro de laterais sem rugosidades.

Quando o número de giros é alcançado, o corpo-de-prova é removido do molde. A massa específica teórica máxima $\left(\mathrm{G}_{\mathrm{mm}}\right)$ é determinada conforme o método AASHTO T-209 (Maximum Specific Gravity of Bituminous Paving Mixtures). A massa específica aparente $\left(\mathrm{G}_{\mathrm{mb}}\right.$, medido $)$ é determinada conforme o método AASHTO T-166 (Bulk Specific Gravity of Compacted Bituminous Mixtures Using Saturated Surface-Dry Specimens).

O valor medido $\left(G_{m b}\right.$, medido $)$ é um pouco menor que o valor calculado $\left(G_{m b}\right.$, estimado $)$ devido à presença de vazios superficiais nas laterais do corpo-deprova. Logo, a massa específica estimada do corpo-de-prova para qualquer número de giros deve ser corrigida por um fator de correção que equivale à relação entre a massa específica medida e a estimada para $\mathrm{N}_{\text {máximo. }}$. Obtêm-se os valores de $\% \mathrm{G}_{\mathrm{mm}}$ para cada corpo-de-prova, dividindo-se a massa específica corrigida $\left(G_{m b}\right.$, corrigida $)$ pelo valor de $G_{m m}$.

As propriedades volumétricas e de densidade dos corpos-de-prova compactados são determinadas e as várias combinações de graduações são comparadas. Critérios volumétricos consistem em determinar:

- porcentagem de vazios no corpo-de-prova compactado;

- vazios do agregado mineral (VAM), definido como a soma de vazios preenchidos pelo ar e pelo ligante efetivo (não absorvido) no corpo-deprova compactado;

- vazios do agregado mineral preenchidos com ligante (RBV). 
Das propriedades volumétricas, a porcentagem de vazios é a mais importante. O critério é fixado em $4 \%$ para todas as misturas e níveis de tráfego. O critério da porcentagem de vazios no agregado mineral (VAM) varia de acordo com o tamanho máximo nominal do agregado. O critério da porcentagem de vazios preenchidos com ligante (RBV) varia em função do tráfego. Outro importante requisito da mistura é a relação entre a porcentagem de material passado pela peneira de abertura $0,075 \mathrm{~mm}$ e o teor efetivo (não absorvido) de asfalto. $\mathrm{O}$ critério é o mesmo para todos os níveis de tráfego.

Todas as informações são analisadas e comparadas com os critérios preconizados no SUPERPAVE $^{\circledR}$ (Tabelas 16 e 17). Qualquer combinação que obedecer a esses critérios poderá ser selecionada. O propósito desta etapa é determinar uma combinação econômica de agregados e ligante que irá proporcionar um bom desempenho ao pavimento.

TABELA 16 - Especificação SUPERPAVE ${ }^{\circledR}$ para projeto volumétrico de misturas (adaptada de SHRP, 1999).

\begin{tabular}{|c|c|c|c|c|c|}
\hline \multirow{2}{*}{$\begin{array}{l}\text { Tráfego - N } \\
\text { (milhões) }\end{array}$} & \multicolumn{3}{|c|}{ Densidade $\left(\% \mathbf{G}_{\mathrm{mm}}\right)$} & \multirow{2}{*}{$\begin{array}{l}\text { Valor Mínimo de } \\
\text { RBV (\%) }\end{array}$} & \multirow{2}{*}{$\begin{array}{c}\text { Relação } \\
\text { Fíler/Asfalto }\end{array}$} \\
\hline & $\mathbf{N}_{\text {inicial }}$ & $\mathbf{N}_{\text {projeto }}$ & $\mathbf{N}_{\text {máximo }}$ & & \\
\hline$<0,3$ & $\leq 91,5$ & \multirow{5}{*}{96,0} & \multirow{5}{*}{$<98,0$} & $70-80^{(3)}$ & \multirow{5}{*}{$0,6-1,6$} \\
\hline 0,3 até $<3$ & $\leq 90,5$ & & & $65-75^{(2)}$ & \\
\hline 3 até $<10$ & & & & \multirow{3}{*}{$65-75^{(2)}$} & \\
\hline 10 até $<30$ & $\leq 89,0$ & & & & \\
\hline$\geq 30$ & & & & & \\
\hline
\end{tabular}

(1) Número equivalente de solicitações do eixo padrão para um período de 20 anos.

(2) Para misturas com tamanho nominal máximo de agregado de 9,5 mm, o RBV deverá variar entre $73 \%$ e $76 \%$ para $\mathrm{N} \geq 3$ milhões.

(3) Para misturas com tamanho nominal máximo de agregado de 25,0 mm, o RBV mínimo deverá ser de $66 \%$ para $\mathrm{N}<0,3$ milhões. 
TABELA 17 - Especificação SUPERPAVE ${ }^{\circledR}$ para VAM (adaptada de SHRP, 1999).

\begin{tabular}{cc}
\hline Tamanho Nominal Máximo do Agregado & Valor Mínimo de VAM (\%) \\
\hline $9,5 \mathrm{~mm}$ & 15,0 \\
$12,5 \mathrm{~mm}$ & 14,0 \\
$19 \mathrm{~mm}$ & 13,0 \\
$25 \mathrm{~mm}$ & 12,0 \\
$37,5 \mathrm{~mm}$ & $11,0^{*}$ \\
\hline
\end{tabular}

* Para misturas com tamanho nominal máximo de agregado de 37,5 mm, o RBV mínimo deverá ser de $63 \%$ para todos os níveis de tráfego.

Segundo KANDHAL et al. (1998a), uma das principais dificuldades encontradas pelos organismos rodoviários nos EUA, quando da implementação do projeto volumétrico de misturas SUPERPAVE ${ }^{\circledR}$, está em satisfazer o VAM mínimo especificado de acordo com o tamanho nominal máximo do agregado. Os baixos VAM dessas misturas estão relacionados ao aumento do esforço de compactação proporcionado pelo compactador giratório e ao uso de misturas mais grossas, com graduação abaixo da zona de restrição, conforme recomenda a especificação para rodovias com alto volume de tráfego.

Uma revisão da literatura conduzida por KANDHAL \& CHAKRABORTY (1996) não indicou a existência de qualquer correlação entre durabilidade de pavimentos asfálticos e os valores mínimos especificados para VAM na fase de projeto das misturas. Vários estudos mostram que a durabilidade está diretamente relacionada à espessura do filme de ligante que recobre os agregados. 
HINRICHSEN \& HEGGEN (1996) consideram que o critério de VAM mínimo é muito restritivo e exclui misturas econômicas e com propriedades aceitáveis de desempenho. Os autores propõem que a espessura do filme de asfalto seja considerada na dosagem das misturas asfálticas e, para tanto, estabelecem equações que consideram a graduação do agregado pétreo e as propriedades volumétricas para determinar o VAM apropriado a cada projeto de mistura.

KANDHAL et al. (1998a) também salientam que o valor mínimo de VAM recomendado na especificação SUPERPAVE ${ }^{\circledR}$ para assegurar a durabilidade da mistura é inadequado, pois penaliza misturas de graduação grossa (que passam abaixo da zona de restrição). Essas misturas podem ter baixo valor de VAM e, ao mesmo tempo, apresentar um aumento na espessura da película de asfalto que recobre o agregado. Os autores recomendam que a espessura mínima do filme de asfalto seja utilizada para assegurar a durabilidade da mistura, ao invés de um VAM mínimo. Sugerem, como último passo do projeto de dosagem SUPERPAVE ${ }^{\circledR}$, o cálculo da espessura do filme de asfalto que deverá ser maior ou igual a $8 \mu \mathrm{m}$.

\section{c) Determinação da Quantidade Ótima de Ligante}

O próximo passo envolve a determinação da quantidade ótima de ligante. Esta fase envolve a mistura e compactação dos corpos-de-prova que são moldados com vários teores de ligante. O número de revoluções, juntamente com os valores de massa específica obtidas para diferentes teores de asfalto, são usados na determinação da quantidade ótima de ligante, em função da porcentagem de vazios admitida. As propriedades da mistura são determinadas para cada teor de ligante asfáltico e gráficos são gerados mostrando a mudança na propriedade da mistura em função das mudanças na quantidade de ligante. 
O teor de ligante asfáltico de projeto corresponde ao teor necessário para a obtenção de $4 \%$ de vazios. Todas as outras propriedades são verificadas no teor de projeto e deverão satisfazer os critérios da especificação SUPERPAVE ${ }^{\circledR}$.

\section{d) Avaliação da Suscetibilidade à Umidade}

A etapa final do método de dosagem SUPERPAVE ${ }^{\circledR}$ consiste na avaliação da sensibilidade à umidade da mistura asfáltica através do método de ensaio AASHTO T-283 (Resistance of Compacted Bituminous Mixture to Moisture Induced Damage). Seis corpos-de-prova são compactados até atingirem um teor de vazios de aproximadamente 7\%. Três desses corpos-de-prova são condicionados à umidade. Todos os corpos-de-prova são avaliados em termos de resistência à tração indireta. Misturas não suscetíveis à umidade apresentam a proporção entre resistência à tração de amostras condicionadas e não condicionadas maior que $70 \%$.

\section{5 - Principais Defeitos de Misturas Asfálticas Densas}

São três os principais mecanismos de deterioração dos pavimentos flexíveis: a deformação permanente, causada pela ação combinada de densificação e deformação por cisalhamento, o trincamento por fadiga, decorrente das repetições de tensão e deformação horizontal na parte inferior do revestimento, e o trincamento a baixas temperaturas. Os próximos itens apresentam uma breve discussão sobre esses parâmetros de desempenho das misturas asfálticas. 


\subsection{1 - Deformação Permanente}

Nos últimos anos, a ocorrência prematura e/ou excessiva de deformação permanente nos pavimentos asfálticos tem sido motivo de grande preocupação entre técnicos e pesquisadores brasileiros da área de pavimentação. As deformações, que aparecem sob a forma de depressões longitudinais nas trilhas de roda, são o resultado da acumulação de pequenos afundamentos que ocorrem toda vez que um carregamento é aplicado. Esse fenômeno tem se agravado devido, principalmente, ao aumento do número de veículos pesados e ao avanço tecnológico que possibilita a esses veículos rodarem com maior carga por eixo e maior pressão nos pneus (FERNANDES JR., 1994).

$\mathrm{O}$ afundamento da trilha de roda pode ser o resultado da escolha de espessuras indevidas das várias camadas que compõem o pavimento, resultando em carregamentos incompatíveis com a capacidade de suporte do subleito. O afundamento também pode ser causado por deformações nas camadas betuminosas, causadas por misturas que possuem pequena resistência ao cisalhamento. Nessas misturas, o afundamento pode ser associado à suscetibilidade térmica dos ligantes ou ao esqueleto mineral resultante de agregados com baixos ângulos de atrito interno.

Embora a seleção apropriada do ligante asfáltico possa minimizar a ocorrência de deformações permanentes, as propriedades dos agregados (tamanho, granulometria, formato das partículas, angularidade e textura superficial) também são muito importantes. Diversas pesquisas têm sido realizadas no sentido de determinar como esses materiais, analisados em termos qualitativos e quantitativos, influem nas misturas asfálticas. A Tabela 18 (SOUZA et al., 
$1991^{1}$ apud COELHO, 1996) apresenta um resumo dos principais fatores que influem na ocorrência das deformações permanentes nas misturas asfálticas preparadas a quente.

TABELA 18 - Fatores que influem nas deformações permanentes de concreto asfáltico (SOUZA et al., $1991^{1}$ apud COELHO, 1996).

\begin{tabular}{|c|c|c|c|}
\hline & Fator & Variação do Fator & $\begin{array}{c}\text { Efeito na } \\
\text { Resistência às } \\
\text { Deformações } \\
\text { Permanentes } \\
\end{array}$ \\
\hline \multirow{4}{*}{ Agregados } & Textura Superficial & Lisa para Rugosa & Aumento \\
\hline & Granulometria & Aberta para Contínua & Aumento \\
\hline & Angularidade & Redondo para Anguloso & Aumento \\
\hline & Tamanho & $\begin{array}{c}\text { Aumento do Tamanho } \\
\text { Máximo }\end{array}$ & Aumento \\
\hline Ligante & Rigidez $^{(a)}$ & Aumento & Aumento \\
\hline \multirow{4}{*}{ Mistura } & Quantidade de Ligante & Aumento & Redução \\
\hline & Volume de Vazios ${ }^{(b)}$ & Aumento & Redução \\
\hline & Vazios dos Agr. Minerais & Aumento & Redução (c) \\
\hline & Método de Compactação & - (d) & $-(d)$ \\
\hline \multirow{4}{*}{$\begin{array}{l}\text { Condições de } \\
\text { Campo e de } \\
\text { Ensaio }\end{array}$} & Temperatura & Aumento & Redução \\
\hline & $\begin{array}{l}\text { Estado de } \\
\text { tensão/deformação }\end{array}$ & $\begin{array}{l}\text { Aumento da pressão de } \\
\text { contato dos pneus }\end{array}$ & Redução \\
\hline & $\begin{array}{l}\text { Repetições do } \\
\text { Carregamento }\end{array}$ & Aumento & Redução \\
\hline & Água & Seco para molhado & $\begin{array}{c}\text { Redução, se a } \\
\text { mistura for sensível à } \\
\text { água }\end{array}$ \\
\hline
\end{tabular}

(a) Refere-se à rigidez na temperatura em que a propensão às deformações permanentes está sendo determinada. A adição de produtos modificadores das características do ligante pode ser usada para aumentar a rigidez desse material nas temperaturas críticas.

(b) Quando o volume de vazios for inferior a 3\%, a propensão às deformações permanentes aumenta.

(c) Valores de VAM muito baixos $(<10 \%)$ devem ser evitados.

(d) O método de compactação, tanto no campo como em laboratório, pode influir na estrutura do material e, conseqüentemente, na sua propensão às deformações permanentes.

${ }^{1}$ SOUZA, J. B.; CRAUSS, J.; MONISMITH, C. L. (1991). Summary Report on Permanent Deformation in Asphalt Concrete. Publicação SHRP-A/IR-91-104. Strategic Highway Research Program, National Research Council, Washington. D. C., 120 p. 
Afundamentos nas trilhas de roda também podem ocorrer, indiretamente, oriundos da desagregação prematura das camadas asfálticas e subseqüente deterioração e/ou consolidação. Pesquisas conduzidas pelo Programa SHRP têm mostrado que as propriedades físico-químicas dos agregados minerais são mais importantes que as propriedades do ligante asfáltico, em termos de adesão e desagregação induzida pela umidade (KANDHAL \& PARKER JR., 1998). A presença de impurezas (pó ou argila) no agregado pode dificultar a coesão entre as partículas, levando ao rompimento das forças de ligação que ajudam a manter a integridade do concreto asfáltico.

\subsection{2 - Trincamento por Fadiga}

O fenômeno de fadiga em revestimentos asfálticos ocorre devido às solicitações repetidas do tráfego e se torna evidente na forma de trincamentos. Trincas por fadiga são causadas por vários fatores que ocorrem simultaneamente. Geralmente a ocorrência está associada à repetição de carregamentos pesados ou quando o número de aplicações de carga ultrapassa o valor previsto em projeto. O problema é agravado quando o subleito apresenta problemas de drenagem. As camadas asfálticas experimentam altas deformações quando as camadas subjacentes são enfraquecidas pelo excesso de umidade e trincam prematuramente. $\mathrm{O}$ aparecimento de trincas por fadiga também pode estar relacionado às falhas de projeto e/ou execução das camadas do pavimento (espessuras inadequadas) que, quando carregadas, estão propensas a altas deflexões (BROWN et al., 2001).

Misturas que apresentam elevado índice de vazios geralmente apresentam menores resistências ao aparecimento de trincas por fadiga. Logo, o volume de vazios afeta a resistência à fadiga e deve ser o menor possível (não inferior a 
3\%, no entanto). O teor de asfalto deve ser tão alto quanto possível, considerando-se, também, a estabilidade (resistência à deformação permanente) e a resistência ao atrito da mistura. $\mathrm{O}$ aumento do teor de asfalto acima de um determinado limite provoca a redução do módulo de rigidez da mistura e, conseqüentemente, a redução da resistência à deformação permanente (HARVEY \& TSAI, 1996).

A graduação dos agregados minerais também apresenta um efeito significativo na rigidez (e, portanto, na vida de fadiga) dos pavimentos asfálticos. Agregados de graduação contínua são recomendados para uso em pavimentos espessos, buscando-se aumentar a rigidez da mistura; por outro lado, agregados de graduação descontínua são recomendados para pavimentos delgados, buscando-se a diminuição da rigidez da mistura.

O formato das partículas, a angularidade e a textura superficial também afetam a resistência à fadiga dos pavimentos asfálticos. Partículas angulares com textura superficial rugosa devem ser consideradas para aumentar a vida de fadiga. Segundo KANDHAL \& PARKER JR. (1998), alguns materiais que passam na peneira de abertura 0,075 $\mathrm{mm}$ (\#200) podem enrijecer excessivamente as misturas, o que contribui para a ocorrência de trincamentos por fadiga.

Ao contrário da trilha de roda, que pode ser evitável, a fadiga não pode ser evitada indefinidamente, devido à repetição das deformações elásticas resultantes do tráfego. Assim, pode-se prevenir os problemas de trincamento por fadiga tomando-se os seguintes cuidados (transcrito de OLIVEIRA, 1997):

- estimar o número de aplicações de carga durante a vida útil proposta;

- manter o subleito seco;

- compatibilizar espessuras e rigidez dos materiais; 
- usar materiais pouco suscetíveis à umidade;

- usar materiais de pavimentação que possuam suficiente resiliência para suportar as deflexões.

\subsection{3 - Trincamento a Baixa Temperatura}

O trincamento por origem térmica é um fenômeno que ocorre mais devido às variações climáticas do que pela ação do tráfego, sendo caracterizado pelo aparecimento de fissuras perpendiculares à direção do tráfego, que ocorrem com um espaçamento praticamente constante. É um tipo de defeito encontrado em países que apresentam temperaturas muito baixas. O pavimento asfáltico sob baixa temperatura se contrai, criando tensões de tração ao longo da camada betuminosa. Quando essas tensões excedem a resistência à tração, a camada asfáltica se rompe.

Os agregados são pouco afetados pela baixa temperatura e, portanto, o trincamento térmico é controlado principalmente pelas propriedades do ligante asfáltico a baixa temperatura. Devem ser selecionados asfaltos com menor rigidez (asfaltos duros são mais propensos ao trincamento térmico) e que não oxidam facilmente (o controle de densidade no campo deve ser rigoroso para evitar a exposição excessiva do ligante ao ar).

Entretanto, se um ligante asfáltico suscetível a altas temperaturas for usado numa mistura contínua e numa mistura de graduação descontínua, a primeira terá alta rigidez e portanto apresentará maior probabilidade de desenvolver trincamento térmico quando comparada à segunda. 


\section{6 - Principais Propriedades dos Agregados Pétreos}

Vários parâmetros de desempenho de misturas asfálticas preparadas a quente são significativamente afetados pelas propriedades dos agregados. Os próximos itens apresentam uma breve discussão dessas propriedades dos agregados.

\subsection{1 - Granulometria e Tamanho do Agregado}

A composição granulométrica dos agregados utilizados nas misturas asfálticas preparadas a quente afeta significativamente o desempenho dos pavimentos. De modo geral, as misturas com curva granulométrica contínua apresentam maior capacidade de resistir às deformações permanentes do que aquelas com granulometria descontínua.

Conforme destacam KANDHAL \& PARKER JR. (1998), misturas asfálticas densas, preparadas com uma graduação conveniente de agregados e com um adequado volume de vazios do agregado mineral (VAM), irá apresentar melhor resistência à degradação durante as fases de construção e sob as cargas do tráfego e também maior resistência ao trincamento por fadiga quando utilizada na construção de pavimentos espessos. Em misturas com granulometria descontínua, é desejável que a graduação escolhida proporcione um grande número de pontos de contato entre as partículas de agregado graúdo, resultando em maior resistência por atrito interno.

O tamanho máximo do agregado também é importante: misturas asfálticas que contém agregados de maior tamanho máximo geralmente resistem melhor à deformação permanente do que aquelas com agregados de menor tamanho. Por outro lado, KANDHAL \& CROSS (1993) destacam que o uso de 
agregados com tamanhos grandes pode vir acompanhado de alguns inconvenientes como baixa trabalhabilidade e tendência à segregação durante a fase de construção.

\subsection{2 - Formato da Partícula, Angularidade e Textura Superficial}

Características como o formato da partícula, angularidade e textura superficial dos agregados graúdos apresentam maior influência em misturas de graduação descontínua do que em misturas de graduação contínua. Tais características em agregados miúdos exercem maior influência nas propriedades físicas das misturas de graduação contínua do que aquelas exercidas pelos agregados graúdos (KANDHAL \& PARKER JR., 1998).

Conforme destacam KIM et al. (1992), o emprego de agregados com maior angularidade e com textura superficial rugosa ao invés de lisa proporciona o melhor travamento entre partículas, aumentando a resistência às deformações permanentes e ao trincamento por fadiga. A resistência ao atrito da camada de rolamento também é melhorada quando tais agregados são utilizados na mistura.

CROSS \& BROWN (1992) afirmam que misturas com maior número de faces fraturadas e com maior angularidade dos agregados miúdos são mais resistentes à ocorrência de deformação permanente.

A presença de partículas achatadas e alongadas nas misturas asfálticas é indesejável pois tais partículas tendem a quebrar (especialmente em misturas de graduação descontínua) durante a produção e construção, afetando assim a durabilidade dos pavimentos asfálticos (BUCHANAN, 2000). 


\subsection{3 - Presença de Materiais Deletérios}

A adesão entre ligante asfáltico e agregados pode ser prejudicada pela presença de pó ou argila nos agregados graúdos e/ou miúdos, o que poderá resultar na desagregação prematura do pavimento. Os agregados devem estar livres de substâncias nocivas como matéria orgânica, argila, pó de pedra etc.

KANDHAL et al. (1998b) recomendam a utilização do ensaio de adsorção de azul de metileno em substituição ao ensaio de equivalente de areia, na avaliação da quantidade e natureza dos materiais deletérios presentes no agregado. O princípio do ensaio fundamenta-se no fato de que o azul de metileno é uma molécula polar que, quando em solução aquosa e em contato com materiais pétreos ou solos, é adsorvido à superfície dos materiais devido à atração elétrica. $\mathrm{O}$ ensaio permite avaliar, nos agregados pétreos, a presença de materiais deletérios (argilo-minerais) ou ainda detectar a presença de fissuras, uma vez que a quantidade de corante consumida no ensaio é proporcional à superfície específica do material analisado (RODGHER, 1996).

\subsection{4 - Resistência à Abrasão e Fragmentação}

Os agregados devem ter resistência à fragmentação (esmagamento) e à abrasão (desgaste provocado pelo atrito). A resistência à fragmentação refere-se à tenacidade do agregado e pode ser avaliada através da determinação do "Índice de Tenacidade Treton". A resistência ao desgaste é avaliada pelo Ensaio de Abrasão Los Angeles (DNER ME 35/98).

Conforme destacam KANDHAL \& PARKER JR. (1998), não existem estudos conclusivos relacionando as propriedades de resistência à abrasão e fragmentação com a degradação que ocorre durante a construção, com as 
propriedades da mistura ou com o desempenho dos pavimentos. Ainda assim, a resistência à abrasão e fragmentação do agregado tem sido usada como prevenção da desintegração e da formação de panelas.

\subsection{5 - Durabilidade e Sanidade}

Um concreto asfáltico bem projetado deve ser resistente às intempéries durante sua vida em serviço. Os agregados podem ficar expostos aos agentes atmosféricos (ciclos de molhagem e secagem, alterações de temperatura) quando eles são quebrados ou esmagados durante a compactação ou quando a película de ligante que os envolve é gasta pela ação do tráfego. A desagregação parcial das camadas de asfalto e/ou a degradação também podem expor as superfícies dos agregados a estas condições. Portanto, os agregados devem ser sãos e resistentes ao intemperismo; agregados que se tornam frágeis ou desintegram quando expostos à umidade, a ciclos de molhagem e secagem ou ao aquecimento e resfriamento devem ser evitados.

O ensaio de sanidade (DNER ME 89/94) é utilizado para avaliar a durabilidade dos agregados pétreos. O ensaio determina a resistência à desintegração dos agregados sujeitos à ação do tempo, pelo ataque de soluções saturadas de sulfato de sódio ou magnésio.

Nem sempre uma boa resistência mecânica garante uma resistência adequada ao intemperismo. Do mesmo modo, um agregado que possui uma boa resistência contra a decomposição físico-química não terá garantido uma alta resistência à fragmentação e ao desgaste. Recomenda-se, portanto, que os ensaios de resistência mecânica sejam complementados pelos ensaios de durabilidade (WU et al., 1998). 
KANDHAL \& PARKER JR. (1998) comentam que a relação existente entre sanidade e desempenho dos pavimentos rígidos (concreto de cimento Portland) é maior do que a relação entre sanidade e o desempenho de pavimentos de concreto asfáltico. Algumas pesquisas também têm estabelecido a relação entre o desempenho de tratamentos superficiais e o ensaio de sanidade. Esses estudos confirmam que a expansão, contração ou desintegração de partículas isoladas do agregado ocorrem mais facilmente em partículas não cobertas (não envolvidas pelo ligante), sendo que a ocorrência é mais severa em pavimentos rígidos.

\subsection{6 - Atrito e Resistência ao Polimento}

A resistência ao atrito da camada de desgaste dos pavimentos asfálticos é um importante parâmetro de desempenho quando a segurança dos motoristas é considerada. Se a resistência ao atrito estiver abaixo de um nível mínimo aceitável, o pavimento não poderá servir à sua função de conforto e segurança. Se a mistura for projetada corretamente (se não houver excesso de asfalto), a resistência ao atrito dependerá da rugosidade do revestimento, que é composta de duas parcelas: macrotextura e microtextura. A macrotextura pode ser obtida através do controle da graduação dos agregados na mistura. A microtextura depende das superfícies expostas dos agregados e, portanto, depende das propriedades dos agregados, incluindo a mineralogia.

As resistências à abrasão e ao polimento são interdependentes: o desgaste inicia-se pelo polimento da face das partículas rugosas (microtextura) exposta à ação do tráfego e continua, progressivamente, pelo desgaste das arestas vivas que se salientam da superfície (macrotextura). A resistência ao polimento (ou desgaste da microtextura) pode ser avaliada em laboratório através de ensaio que utiliza um equipamento denominado Pêndulo Britânico, onde é simulada a 
ação abrasiva do tráfego sobre uma amostra do revestimento e determinado o coeficiente de atrito após o desgaste. Pode-se avaliar a macrotextura através do ensaio de mancha de areia (ASTM E 965/87 - Standarf Test Method for Measuring Surface Macrotexture Depth Using a Volumetric Technique).

A microtextura das partículas do agregado graúdo tem sido utilizada como o principal parâmetro de aceitabilidade dos agregados, devendo garantir a resistência ao atrito. Entretanto, o tamanho do agregado também irá influenciar no atrito pneu-pavimento. Além disso, outras propriedades das misturas como teor de asfalto e porcentagem de vazios também afetam o atrito superficial.

Em razão da complexidade do problema, ensaios que verificam apenas a microtextura do agregado graúdo podem não ser um mecanismo eficiente de avaliação da resistência ao polimento. Conforme destacam KANDHAL \& PARKER JR. (1998), existe a necessidade do desenvolvimento de novos métodos de ensaio para avaliação da resistência ao polimento, que deverão ser incluídos no processo de dosagem das misturas asfálticas.

\subsection{7 - Mineralogia}

Segundo KANDHAL \& PARKER JR. (1998), não existe uma forte relação entre mineralogia ou petrografia e o desempenho dos concretos asfálticos. Isto pode ocorrer devido ao fato de que todas as partículas de agregado nos concretos asfálticos são envolvidas por uma fina película de ligante asfáltico.

Entretanto, vários estudos têm revelado relação entre a mineralogia do agregado e as propriedades de polidez e atrito. Tais estudos têm sugerido que as informações petrográficas devem ser empregadas juntamente com os 
ensaios físicos no estabelecimento de critérios para polidez e atrito dos agregados. A ocorrência de desagregação nos pavimentos asfálticos também é afetada pela mineralogia, apesar de não ter sido verificada uma relação direta.

\subsection{8 - Propriedades Químicas}

Os agregados são compostos de minerais. Cada mineral tem uma composição química e estrutura cristalina característica. Pesquisas desenvolvidas no Programa SHRP confirmam que a composição química e mineralógica dos agregados influi decisivamente na ocorrência da desagregação causada pela perda de adesividade entre agregados e ligante asfáltico na presença de umidade (KANDHAL \& PARKER JR., 1998).

Agregados chamados hidrófilos apresentam maior afinidade com a água do que com o ligante asfáltico. De maneira geral, os agregados hidrófilos são ácidos e contém alto teor de sílica, como os granitos e quartzitos. Agregados básicos, como as rochas calcárias, são chamados hidrofóbicos por serem mais facilmente molhados pelo cimento asfáltico do que pela água. Segundo HICKS (1991), alguns autores classificam os agregados como "eletropositivo", caso dos agregados calcários que possuem carga superficial positiva, e "eletronegativo", caso dos agregados silicosos que possuem carga superficial negativa na presença de água. Entretanto, a composição mineral da maioria dos agregados possibilita a ocorrência dos dois tipos de cargas elétricas.

As propriedades químicas dos agregados também podem influenciar os parâmetros de desempenho dos concretos asfálticos tais como a deformação permanente e a desintegração, ambas resultantes da perda de adesão entre agregado e ligante. 


\subsection{9 - Propriedades do Fíler Mineral}

O fíler, ou material de enchimento, tem recebido dos pesquisadores uma atenção especial devido à importância que essa fração tem demonstrado ter nas características das misturas e, conseqüentemente, no desempenho dos concretos asfálticos. É um material que possui a maior parte de suas partículas (no mínimo 65\%) com dimensão nominal máxima inferior a $0,075 \mathrm{~mm}$. Segundo ISHAI \& CRAUS (1996), uma parcela do fíler atua como material inerte, preenchendo vazios; a outra parcela, denominada fíler ativo, fica em suspensão no ligante asfáltico.

Estudos conduzidos por TAYEBALI et al. (1998) indicam que o aumento da quantidade de fíler nas misturas asfálticas pode não comprometer o desempenho em termos de deformação permanente. Ao contrário, resultados do estudo mostraram que o aumento da quantidade de alguns tipos de fíler, dentro de certos limites, tem efeito benéfico em termos de deformação permanente, por aumentar a rigidez do ligante asfáltico.

Entretanto, uma alta quantidade de fíler implica na redução da quantidade de asfalto livre, o que pode levar ao efeito prejudicial das outras propriedades da mistura tais como fadiga, trincamento térmico e desintegração. Logo, é muito importante caracterizar o fíler de modo que o desempenho dos pavimentos asfálticos não seja comprometido. 


\section{4 - UtilizaÇÃo de Borracha de Pneus EM PaVimentaÇÃo ASFáltica}

\section{1 - INTRODUÇÃO}

Nos últimos anos, a utilização de borracha triturada de pneus nas misturas asfálticas tem aumentado consideravelmente, particularmente nos EUA. As razões para esse aumento são duas: a existência de legislação específica, que traz o benefício da reciclagem para este tipo de resíduo, e a potencialidade de obtenção de um pavimento com melhor desempenho em longo prazo, superando as limitações dos pavimentos tradicionais.

Existem dois métodos de incorporação da borracha de pneus nas misturas asfálticas:

- No processo úmido (wet process), partículas finas de borracha são misturadas ao cimento asfáltico aquecido, produzindo um novo tipo de ligante denominado "asfalto-borracha". O ligante asfalto-borracha pode ser utilizado em concretos asfálticos usinados a quente (CBUQ), em tratamentos superficiais (SAM - Stress Absorbing Membranes), entre camadas de CBUQ quando for executado um reforço (SAMI - Stress Absorbing Membrane Interlayer) e para selagem de trincas e juntas; 
- No processo seco (dry process), partículas maiores de borracha substituem parte dos agregados pétreos que, com a adição do ligante asfáltico, formam um produto denominado "concreto asfáltico modificado com adição de borracha" - Figura 16. O agregado-borracha deve ser utilizado somente em concretos asfálticos usinados a quente (CBUQ). Esta pesquisa tem o processo seco como seu principal objeto.

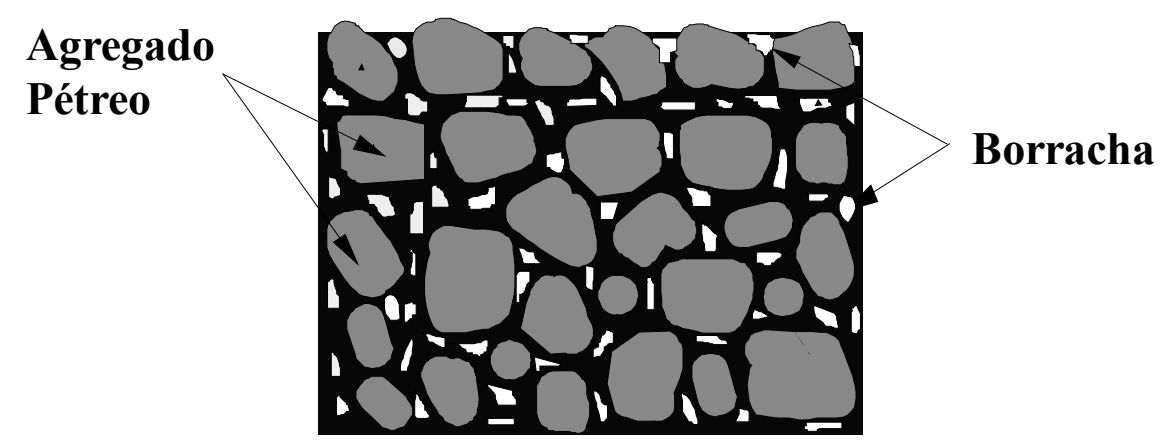

FIGURA 16 - Processo seco de incorporação de borracha em misturas asfálticas.

\section{2 - HisTóRICO}

Conforme destaca HEITZMAN (1992), os processos de incorporação de borracha de pneus nas misturas asfálticas não foram desenvolvido como uma solução para o grave problema ambiental da disposição dos pneus inservíveis. Há anos têm sido realizadas pesquisas sobre a incorporação de borracha natural (látex) e borracha sintética (polímeros) em cimentos asfálticos visando melhorar as propriedades elásticas do ligante. Segundo ZANZOTTO \& KENNEPOHL (1996), a primeira patente de combinação de material betuminoso com borracha natural para a construção de pavimentos foi 
conferida a E. E. Cassell em 1844. A borracha de pneu, um composto de borracha natural e sintética, é uma matéria-prima disponível que pode ser utilizada não só como agente modificador de asfalto, mas também como agregados nas misturas betuminosas.

O desenvolvimento tecnológico da adição de borracha de pneu como material de pavimentação asfáltica teve início nos anos 1960, quando o engenheiro Charles McDonald desenvolveu um ligante asfáltico modificado com a adição borracha triturada denominado Overflex ${ }^{\circledR}$ (processo úmido). Na metade dos anos 1970, a Companhia de Refinação do Arizona (ARCO - Arizona Refining Company) desenvolveu uma tecnologia similar de adição de borracha triturada ao ligante asfáltico, que foi chamada de Arm-R-Shield ${ }^{\circledR}$. Atualmente, ambos os sistemas são conhecidos como tecnologia McDonald.

Também nos anos 1960, ao mesmo tempo em que o asfalto-borracha estava ganhando notoriedade nos EUA, duas empresas suecas desenvolveram um método de incorporação de pequena quantidade de borracha triturada em substituição de parte dos agregados nas misturas asfálticas (processo seco). No fim dos anos 1970, este produto denominado Rubit ${ }^{\circledR}$ foi introduzido e patenteado nos Estados Unidos com o nome de PlusRide ${ }^{\circledR}$.

A preocupação crescente com os aspectos ambientais, manifestada inclusive por leis que regulamentam o uso de borracha de pneus em misturas asfálticas, trouxe uma nova motivação para estudos sobre o tema, contribuindo para o aprimoramento das técnicas disponíveis e o desenvolvimento de novas tecnologias. A Tabela 19 (adaptada de EPPS, 1994) apresenta algumas das principais tecnologias de incorporação de borracha reciclada de pneus em misturas asfálticas pelos processos seco e úmido. 
TABELA 19 - Algumas das tecnologias de incorporação de borracha de pneus em misturas asfálticas (adaptada de EPPS, 1994).

\begin{tabular}{|c|c|c|}
\hline \multicolumn{2}{|c|}{ Tecnologia } & \multirow[b]{2}{*}{$\begin{array}{l}\text { Características } \\
\text { Desenvolvida nos anos } 1960 \text { no Arizona - EUA. } \\
\text { Consiste na mistura de cimento asfáltico e } \\
\text { borracha triturada ( } 15 \text { a } 25 \% \text { em relação ao peso } \\
\text { de ligante), a uma temperatura elevada (170 a } \\
\left.200^{\circ} \mathrm{C}\right) \text {, durante um determinado período de } \\
\text { tempo ( } 20 \text { a } 120 \text { minutos). A mistura reage e } \\
\text { forma um composto denominado asfalto-borracha, } \\
\text { com propriedades reológicas diferentes do ligante } \\
\text { original, podendo ser incorporado aditivo para } \\
\text { ajustar a viscosidade da mistura. }\end{array}$} \\
\hline \multirow{3}{*}{ Processo Úmido } & $\begin{array}{l}\text { McDonald } \\
\left(\text { Overflex }^{\circledR} \mathrm{e}\right. \\
\left.\text { Arm-R-Shield }^{\circledR}\right)\end{array}$ & \\
\hline & $\begin{array}{l}\text { Continuous Blending } \\
\text { (Florida wet process) }\end{array}$ & $\begin{array}{l}\text { Desenvolvida em } 1989 \text { na Florida - EUA. } \\
\text { Partículas finas de borracha são adicionadas ao } \\
\text { cimento asfáltico em um processo contínuo. Essa } \\
\text { tecnologia difere do processo McDonald em } \\
\text { vários aspectos: são adicionados menores teores } \\
\text { de borracha ( } 8 \text { a } 10 \%) \text {, as partículas de borracha } \\
\text { são mais finas e a temperatura durante a } \\
\text { misturação e o tempo de reação são menores. }\end{array}$ \\
\hline & Terminal Blending & $\begin{array}{l}\text { Desenvolvida em } 1992 \text { - Arizona / Washington - } \\
\text { EUA. Essa tecnologia permite a armazenagem } \\
\text { prolongada do ligante asfalto-borracha. }\end{array}$ \\
\hline \multirow{3}{*}{ Processo Seco } & PlusRide $^{\circledR}$ & $\begin{array}{l}\text { Desenvolvida nos anos } 60 \text { - Suécia. Os agregados } \\
\text { pétreos apresentam descontinuidade na sua curva } \\
\text { de distribuição granulométrica para acomodar } \\
\text { partículas relativamente grandes de borracha (até } \\
1 / 4 \text { ") nos teores especificados (geralmente } 3 \% \mathrm{em} \\
\text { relação ao peso total da mistura). }\end{array}$ \\
\hline & $\begin{array}{l}\text { Genérica } \\
\text { (Generic System) }\end{array}$ & $\begin{array}{l}\text { Desenvolvida por H. B. Takallou em } 1989 \text { - Nova } \\
\text { York - EUA. Neste método são utilizadas curvas } \\
\text { granulométricas densas onde parte dos agregados } \\
\text { pétreos é substituído por partículas de borracha } \\
\text { com granulometria mais fina (para que ocorra } \\
\text { reação parcial com o ligante asfáltico) e em } \\
\text { menores teores (geralmente } 2 \% \text { em relação ao } \\
\text { peso total da mistura para camadas de rolamento). }\end{array}$ \\
\hline & $\begin{array}{l}\text { Chunk Rubber } \\
\text { (borracha "graúda") }\end{array}$ & $\begin{array}{l}\text { Desenvolvida em } 1990 \text { - EUA. Este método foi } \\
\text { desenvolvido com o objetivo de melhorar as } \\
\text { características dos pavimentos asfálticos a serem } \\
\text { construídos em regiões de clima frio. As pesquisas } \\
\text { se concentraram no aumento do tamanho das } \\
\text { partículas de borracha e no aumento da } \\
\text { quantidade de borracha incorporada nas misturas } \\
\text { asfálticas, utilizando os conceitos do sistema } \\
\text { PlusRide }{ }^{\circledR} \text {. }\end{array}$ \\
\hline
\end{tabular}


ROBERTS et al. (1989) destacam as principais diferenças entre os dois processos:

- O tamanho das partículas - no processo seco geralmente são utilizadas partículas maiores de borracha;

- A quantidade de borracha - nas misturas preparadas pelo processo seco, a borracha triturada pode representar até 3\% em relação ao peso total da mistura enquanto que no processo úmido, a borracha pode representar até $25 \%$ em relação ao peso do ligante ou $1,5 \%$ em relação à mistura. Portanto, o processo seco pode utilizar até duas vezes mais borracha do que o processo úmido;

- A função da borracha - no processo seco, a borracha triturada pode atuar como agregado ou como agente modificador de ligante, enquanto que no processo úmido a borracha atua principalmente como modificador de ligante. O grau de modificação do ligante depende de vários fatores, incluindo o tamanho e a textura da borracha, a proporção de cimento asfáltico e borracha, o tempo e a temperatura de reação, a compatibilidade com a borracha e o grau de energia mecânica durante a misturação;

- A facilidade de incorporação - no processo seco não são necessários equipamentos especiais ou mudanças significativas na usina enquanto que no processo úmido são necessárias unidades especiais para dosagem, com tanques para misturação em elevada temperatura para que ocorra a reação adequada entre o ligante e a borracha até que a viscosidade seja estabilizada. Os custos de mobilização dos equipamentos (unidades de mistura e dosagem, tanques de armazenagem etc.) são repassados ao preço do ligante, contribuindo para o maior custo do processo úmido quando comparado ao processo seco. 
Apesar do processo seco apresentar algumas vantagens em relação ao processo úmido, principalmente em relação aos custos envolvidos e à maior quantidade de borracha a ser utilizada, as pesquisas em todo o mundo têm-se concentrado principalmente no processo úmido. Essa escolha pode ser explicada pelo desempenho irregular de alguns trechos experimentais construídos nos EUA com o processo seco, diferentemente do processo úmido, que tem apresentado resultados mais satisfatórios. A tecnologia do processo úmido está mais bem fundamentada, inclusive com o desenvolvimento de equipamentos especiais, e o desempenho em campo indica que a presença de borracha produz efeitos benéficos. Análises laboratoriais indicam o aumento da vida em serviço que podem compensar o maior custo inicial.

É importante salientar que ainda não existem resultados conclusivos sobre o desempenho dos pavimentos que contêm borracha de pneu triturada. A tecnologia de ensaios, projetos e avaliação de ligantes e misturas modificadas com adição de borracha ainda não está totalmente compreendida. Conforme destacam TROY et al. (1996), considerações de projeto tais como tipo e teor de cimento asfáltico, tipo de borracha, granulometria da borracha, temperaturas de mistura e compactação, entre outros, estão relativamente indefinidos. Portanto, existe a necessidade de estabelecimento de procedimentos padronizados para o projeto e avaliação de misturas modificadas com adição de borracha reciclada.

A incorporação de borracha pelo processo seco tem-se mostrado mais indicado para o contexto brasileiro devido principalmente à facilidade de adaptação nas usinas asfálticas e à maior potencialidade de consumo de pneus inservíveis. No Brasil, a necessidade de estudos complementares, para um melhor entendimento dos efeitos dos fatores intervenientes sobre as propriedades de engenharia das misturas asfálticas com adição de borracha de pneus usados, 
ganha ainda maior importância em razão de termos diferentes materiais (agregados pétreos e ligantes asfálticos), técnicas e cuidados construtivos e condições climáticas quando comparado com as condições que prevalecem nos Estados Unidos e Europa.

\section{3 - Processo Seco}

São dois os principais métodos de incorporação de borracha de pneus nas misturas asfálticas pelo processo seco: a tecnologia PlusRide ${ }^{\circledR}$ e o sistema genérico (generic system).

O sistema PlusRide ${ }^{\circledR}$ permite a incorporação de 3\% (em relação ao peso total da mistura) de borracha com diâmetros que variam entre 2 e 6,35 mm. As especificações de graduação do agregado pétreo, para diferentes níveis de tráfego, apresentam descontinuidade em sua faixa granulométrica. As partículas de borracha substituem a porção de agregado que normalmente ocuparia este espaço.

O tipo de asfalto utilizado nas misturas modificadas com borracha pelo sistema PlusRide ${ }^{\circledR}$ pode ser o mesmo que o utilizado nas misturas convencionais. Entretanto, misturas modificadas com borracha requerem uma quantidade maior de asfalto, cerca de 1,5 a $2 \%$ a mais em relação às misturas convencionais (o que pode retardar o envelhecimento da mistura e aumentar a resistência às trincas por fadiga do revestimento). $\mathrm{Na}$ dosagem pelo método Marshall, o único critério utilizado na determinação do teor ótimo de asfalto é o volume de vazios, que deve variar entre 2 e $4 \%$, dependendo do volume de tráfego. 
A Tabela 20 (adaptada de EATON et al., 1991) apresenta as especificações do método PlusRide ${ }^{\circledR}$, recomendadas para diferentes níveis de tráfego.

TABELA 20 - Especificações recomendadas para misturas modificadas com borracha, para diferentes níveis de tráfego (adaptada de EATON et al., 1991).

\begin{tabular}{|c|c|c|c|}
\hline Características & $\begin{array}{c}\text { PlusRide }^{\circledR} \\
9^{*}\end{array}$ & $\begin{array}{c}\text { PlusRide }^{\circledR} \\
12^{*}\end{array}$ & $\begin{array}{c}\text { PlusRide }^{\circledR} \\
16^{*}\end{array}$ \\
\hline Tráfego diário médio & $<2500$ & $2500-10000$ & $>10000$ \\
\hline Espessura mínima & $0,75^{\prime \prime}(1,9 \mathrm{~cm})$ & $1,5^{\prime \prime}(3,8 \mathrm{~cm})$ & $1,75^{\prime \prime}(4,5 \mathrm{~cm})$ \\
\hline \multicolumn{4}{|l|}{ Agregado - \% passando } \\
\hline \multicolumn{4}{|l|}{ Peneiras } \\
\hline 3/4" & - & - & 100 \\
\hline $5 / 8^{\prime \prime}$ & - & 100 & - \\
\hline 1/2" & - & - & $65-80$ \\
\hline $3 / 8^{\prime \prime}$ & 100 & $60-80$ & $50-60$ \\
\hline $1 / 4 "$ & $60-80$ & $30-42$ & $30-42$ \\
\hline$\# 10$ & $23-38$ & $19-32$ & $19-32$ \\
\hline$\# 30$ & $15-27$ & $13-25$ & $12-23$ \\
\hline \#200 & $7-11$ & $8-12$ & $6-10$ \\
\hline \multicolumn{4}{|l|}{ Dosagem preliminar: } \\
\hline \multicolumn{4}{|l|}{ Borracha, $\%$ do total } \\
\hline em peso & 3,0 & 3,0 & 3,0 \\
\hline em volume (aprox.) & 6,7 & 6,7 & 6,7 \\
\hline \multicolumn{4}{|l|}{ Asfalto, $\%$ do total } \\
\hline em peso & 7,5 & 7,5 & 7,5 \\
\hline em volume (aprox.) & 20,2 & 20,2 & 20,2 \\
\hline Vazios máximo (\%) & 2 & 3 & 4 \\
\hline
\end{tabular}

* Diâmetro máximo do agregado.

As partículas de borracha obtidas na trituração devem possuir formato cúbico. A borracha não deverá conter fibras de tecido e aço e deverá satisfazer a especificação de graduação conforme Tabela 21 (FHWA, 1993). 
TABELA 21 - Especificação PlusRide ${ }^{\circledR}$ para a borracha (FHWA, 1993).

\begin{tabular}{cc}
\hline Peneira & Porcentagem Passando \\
\hline $1 / 4 "$ & 100 \\
$\# 4$ & $76-100$ \\
$\# 10$ & $28-42$ \\
$\# 20$ & $18-24$ \\
\hline
\end{tabular}

Estudos conduzidos por TAKALLOU et al. (1986) e TAKALLOU \& HICKS (1988) indicam que as misturas modificadas com borracha pelo sistema PlusRide $^{\circledR}$ apresentam maior resistência à fadiga do que as misturas convencionais. Também apresentam maior resistência ao trincamento térmico, pois as partículas de borracha absorvem as tensões, retardando a propagação de trincas.

Diferentemente do sistema PlusRide ${ }^{\circledR}$, o sistema genérico de adição de borracha utiliza curvas granulométricas tradicionais (densas) onde são incorporadas partículas de borracha com diâmetro nominal máximo de $2,00 \mathrm{~mm}$ (\#10). A quantidade de borracha não deve exceder a $2 \%$ para a camada de rolamento e 3\% para camada de ligação (binder), em relação ao peso total da mistura.

As partículas de borracha devem possuir formato cúbico e não devem conter resíduos de fibras e metais. A diferença dos pesos específicos entre a borracha e o agregado pétreo requer um fator de ajuste (volumétrico) quando do estabelecimento das proporções que devem ser adicionadas de cada material para a obtenção de uma mistura granulométrica que se enquadre na faixa especificada (FHWA, 1993). 
$\mathrm{Na}$ dosagem pelo método Marshall, devem ser considerados os seguintes critérios para a determinação do teor ótimo de asfalto: o volume de vazios deve variar entre 2 e 4\%, a estabilidade deve obedecer o limite mínimo recomendado em norma e a fluência não deve exceder a 20 (0,01 pol.).

Existem inúmeros fatores que devem ser considerados, particularmente a forma como a borracha triturada irá alterar as propriedades da mistura: no sistema PlusRide ${ }^{\circledR}$ a modificação da mistura se dá com a substituição dos agregados pela borracha; no sistema genérico, também o ligante é modificado pois são utilizadas partículas menores de borracha, ocorrendo reação entre a borracha e o ligante anteriormente ao lançamento e compactação da mistura.

No sistema genérico, enquanto as partículas finas de borracha reagem com o ligante, as partículas maiores atuam como "agregados elásticos" no concreto asfáltico. A combinação de ligante modificado e aumento da elasticidade das misturas asfálticas tende a produzir pavimentos mais resistentes à fadiga e ao trincamento a baixas temperaturas (FHWA, 1993).

Em ambos os sistemas, a borracha triturada deve ser considerada como um agregado, sendo misturada com o agregado mineral previamente aquecido antes da adição do ligante asfáltico. A parcela de borracha fina, que passa na peneira de abertura 0,84 $\mathrm{mm}(\# 20)$, reage parcialmente com o ligante. Essa ocorrência se torna evidente quando, após a misturação, é verificado o "aumento do volume" da mistura. Para evitar a expansão dos corpos-de-prova após a compactação em laboratório, podem ser encaixados tampões no topo e na base dos moldes durante o resfriamento, que teria efeito equivalente à compactação no campo até a temperatura atingir $60^{\circ} \mathrm{C}$ (FHWA, 1993).

A produção dos concretos asfálticos modificados com borracha podem ser efetuada em usinas gravimétricas, volumétricas e tipo "drum-mixer". 
Entretanto, a utilização de usinas gravimétricas é preferível pois a dosagem dos agregados e da borracha é feita em peso e antes da adição do ligante asfáltico. É fundamental que haja um rigoroso controle da quantidade de borracha a ser adicionada e que essa borracha seja distribuída de maneira uniforme na mistura.

A compressão da mistura na pista deve ser feita com rolo metálico liso e deve perdurar até que temperatura da mistura seja inferior a $60^{\circ} \mathrm{C}$. As rodas dos rolos deverão ser umedecidas adequadamente para evitar a aderência da mistura. Rolos pneumáticos devem ser evitados.

\subsection{1 - Considerações sobre a Dosagem}

Conforme destacam TAKALLOU \& HICKS (1988), as misturas asfálticas modificadas com adição de borracha podem ser dosadas pelos métodos tradicionais como o método Marshall. Entretanto, os critérios para a determinação do teor ótimo de asfalto são diferentes para misturas convencionais e misturas modificadas com borracha.

$\mathrm{Na}$ dosagem das misturas asfálticas pelo método Marshall são considerados vários parâmetros como estabilidade, fluência, volume de vazios e relação betume/vazios. Estes parâmetros devem obedecer determinados limites especificados em norma. Entretanto, experiências de dosagem de misturas modificadas com borracha pelo método Marshall têm mostrado que:

- valores de estabilidade para misturas modificadas são menores quando comparados aos valores obtidos com misturas convencionais;

- valores de fluência para misturas modificadas geralmente são maiores do que o valor máximo admissível nos critérios de dosagem de misturas convencionais. 
Experiências realizadas no Estado do Alasca (TAKALLOU et al., 1986; TAKALLOU \& HICKS, 1988) indicam que o principal fator para o sucesso de misturas asfálticas modificadas com adição de borracha pelo sistema PlusRide $^{\circledR}$ tem sido a baixa porcentagem de vazios na mistura. Pavimentos construídos no Alasca com baixo valor de volume de vazios e que apresentam desempenho satisfatório possuem estabilidade abaixo de $175 \mathrm{kgf}$ e fluência de até 19 ( 0,01 pol.). Em geral, é recomendado que o volume de vazios obtido em laboratório varie entre 2 e $4 \%$, dependendo do volume de tráfego.

Deste modo, diferentes critérios devem ser desenvolvidos de acordo com os indicadores de desempenho das misturas modificadas com adição de borracha. Têm sido realizadas experiências internacionais, principalmente nos Estados Unidos, de dosagem de misturas modificadas com borracha de pneus utilizando o sistema SUPERPAVE ${ }^{\circledR}$ (HAFEZ \& WITCZAK, 1995; GOWDA et al., 1996).

Embora as pesquisas do programa SHRP se concentrem nos ligantes e misturas asfálticas convencionais, os ensaios de laboratório do SUPERPAVE ${ }^{\circledR}$ foram concebidos para serem aplicados a todos os tipos de misturas asfálticas preparadas a quente, sejam elas virgens ou recicladas, de graduação contínua ou descontínua, com ou sem modificadores.

O procedimento de dosagem SUPERPAVE ${ }^{\circledR}$ de misturas asfálticas é claramente distinto dos métodos convencionais de dosagem, como o método Marshall. Não apenas os ligantes são avaliados considerando-se parâmetros de desempenho, mas também as misturas são preparadas em laboratório simulando a produção e compactação no campo. Duas diferenças significativas no processo de preparação dos corpos-de-prova: o envelhecimento das misturas não-compactadas em estufa (envelhecimento de 
curto-prazo) e o compactador giratório que simula a compactação no campo, considerando condições particulares de tráfego.

O método de dosagem Marshall utiliza o soquete de impacto para obter o nível de compactação de projeto (volume de vazios) que servirá como base no estabelecimento do teor de asfalto. A energia de compactação é controlada pelo número de golpes (função do tráfego) do soquete compactador.

Logo, qualquer tentativa de comparação entre os procedimentos tradicionais de dosagem e o SUPERPAVE ${ }^{\circledR}$ deverá isolar o efeito do envelhecimento e compactação e considerar devidamente uma ampla gama de variáveis como tipos de agregados, ligantes e modificadores.

Estudos conduzidos por HAFEZ \& WITCZAK (1995) indicaram que o método de dosagem SUPERPAVE ${ }^{\circledR}$ não é apropriado para determinar a quantidade ótima de ligante em misturas que utilizam o processo seco de incorporação de borracha. Esta limitação pode estar associada a duas propriedades do processo seco. A primeira propriedade está relacionada à natureza altamente resiliente das partículas de borracha que substituem parte dos agregados na mistura: durante o processo de compactação giratória, ocorrem alterações na altura (alterações volumétricas); após o processo de compactação, pode ocorrer uma reação súbita do corpo-de-prova, pois o dispositivo giratório compactou uma série de "molas" elásticas.

A segunda característica dessas misturas está relacionada à expansão do corpo-de-prova após o término do processo de compactação. Este aumento de volume é um fenômeno dependente do tempo cuja magnitude está relacionada à complexa interação entre tipo de borracha/graduação, porcentagens de borracha e de ligante e temperatura durante o processo de compactação. Essas duas particularidades relacionadas às alterações volumétricas são responsáveis 
pela interpretação incorreta dos resultados obtidos em laboratório (curvas de compactação).

Por outro lado, GOWDA et al. (1996) não relataram qualquer problema relacionado à utilização do compactador giratório. Na dosagem de misturas modificadas pelo processo seco (sistema genérico) foram adicionadas partículas muito finas de borracha (passando na peneira \#200, de abertura $0,075 \mathrm{~mm}$ ) nos teores de 1, 2 e 3\% em relação ao peso de agregado. Nos experimentos de HAFEZ \& WITCZAK (1995), as misturas foram preparadas pelo sistema PlusRide ${ }^{\circledR}$ ( $3 \%$ de borracha) e genérico $(1,2$ e 3\% de borracha) os autores não especificaram as granulometrias de borracha utilizadas.

\subsection{2 - Comportamento ao Envelhecimento das Misturas Asfálticas Modificadas com Adição de Borracha}

Uma mistura asfáltica envelhece tanto durante a construção (curto prazo) como durante a vida em serviço do pavimento (longo prazo), mudando seu comportamento frente às solicitações do tráfego e ambientais. As propriedades e o desempenho das misturas asfálticas, portanto, podem ser melhor avaliadas quando são usadas amostras envelhecidas.

A avaliação dos efeitos do envelhecimento em serviço, considerando apenas o cimento asfáltico, esbarra na dificuldade em recuperar uma quantidade suficiente e adequada de ligante de corpos-de-prova extraídos do pavimento. Uma forma de inferir o efeito do envelhecimento do ligante na qualidade e no desempenho da camada asfáltica parece ser a de ensaiar a mistura, em diferentes idades, através de ensaios mecânicos. 
No procedimento de dosagem SUPERPAVE ${ }^{\circledR}$, a mistura não-compactada é envelhecida em estufa, durante 2 ou 4 horas (curto prazo). Se os agregados utilizados apresentarem absorção menor que $2 \%$, a mistura será mantida em estufa por 2 horas, na temperatura de compactação. Se a absorção for maior que $2 \%$, a mistura será mantida em estufa a $135^{\circ} \mathrm{C}$, durante 4 horas. Para simular o envelhecimento de longo prazo, a mistura compactada é mantida em uma estufa a $85^{\circ} \mathrm{C}$, durante 120 horas (SHRP, 1999).

Nas misturas contendo borracha ocorre um processo chamado de "digestão" da borracha, ou seja, a interação asfalto-borracha no intervalo de tempo que compreende as fases de preparação, transporte e lançamento da mistura na pista. Segundo OLIVER (2000), no processo seco, uma vez que o ligante é adicionado ao conjunto agregado-borracha, não é possível determinar claramente as alterações nas propriedades do ligante. O processo úmido possui a vantagem de ter as propriedades do ligante melhor controladas.

Segundo VAN KIRK \& HOLLERAN (2000), uma das razões para explicar o desempenho irregular das misturas preparadas pelo processo seco está relacionada ao tempo insuficiente para que ocorra a reação ou interação entre o cimento asfáltico e as partículas mais finas de borracha.

Estudos conduzidos por GALLEGO et al. (2000) ressaltam a importância do tempo de digestão como o parâmetro de maior influência sobre o desempenho de curto prazo de misturas preparadas pelo processo seco. Os autores propõem um procedimento de dosagem que considera as seguintes variáveis: tempo de digestão (de acordo com a distância de transporte), graduação e quantidade de borracha. O método Marshall é utilizado na escolha inicial do teor de asfalto, que deverá ser verificado através de dois outros ensaios: o método ASTM D 1075/96 - "Effect of Water on Compressive Strength of Compacted Bituminous Mixtures", que descreve a perda da resistência à compressão axial simples 
resultante da ação da água em amostras de misturas asfálticas compactadas e o ensaio de trilha de roda para análise da capacidade da mistura de suportar deformações permanentes.

A relação entre resistência à compressão simples antes e após o condicionamento $\left(24 \mathrm{~h}, 60^{\circ} \mathrm{C}\right)$ deve ser superior a $75 \%$. Os ensaios mostram que o comportamento do material melhora com o aumento do tempo de digestão e com a diminuição da quantidade e do tamanho das partículas de borracha.

GALLEGO et al. (2000) citam a construção de trechos experimentais na Espanha que confirmam os resultados obtidos em laboratório e a importância do tempo de digestão no desempenho de curto prazo de pavimentos que incorporam borracha pelo processo seco:

- No primeiro trecho (volume de tráfego diário de 6.200 veículos - 8\% de caminhões), foram construídas duas seções de pavimento contendo $1 \%$ de borracha em relação ao peso de agregado. O tempo decorrido entre a produção, o transporte e a compactação da mistura foi de aproximadamente 90 minutos. O desempenho, após quatro anos da construção, foi considerado excelente;

- No segundo trecho (3.200 veículos/dia - 14\% de caminhões), também foram construídas duas seções de pavimento contendo $1 \%$ de borracha em relação ao peso de agregado. Entretanto, a distância entre a usina e o local a ser pavimentado compreendia apenas $5 \mathrm{~km}$, resultando num tempo de digestão de aproximadamente 20 minutos. Após seis meses da construção, as seções apresentaram sérios problemas de desagregação. 
Resultados laboratoriais também indicam o efeito benéfico do tempo de digestão sobre a vida de fadiga das misturas modificadas: misturas contendo borracha forneceram amostras menos resistentes à fadiga quando comparadas à mistura de controle (todas com moldagem imediata). Entretanto, quando as mesmas misturas não-compactadas foram deixadas em estufa $\left(2 \mathrm{~h}, 150^{\circ} \mathrm{C}\right)$, as misturas contendo borracha apresentaram desempenho similar à mistura de controle (GALLEGO et al., 2000).

LIANG \& LEE (1996) apresentam alguns resultados de ensaios de envelhecimento de curto e longo prazo em misturas asfálticas modificadas com adição de borracha, que podem ser assim resumidos: as misturas asfálticas modificadas com adição de borracha apresentam menor resistência à tração quando comparadas à mistura de controle e o envelhecimento de curto $\mathrm{e}$ longo prazo aumenta a resistência à tração indireta destas misturas. Conseqüentemente, misturas asfálticas convencionais apresentam diferenças maiores entre misturas envelhecidas (curto e longo prazo), quando comparadas às misturas modificadas com borracha.

\subsection{3 - Experiência Internacional}

Estudo realizado no estado americano de Arkansas por GOWDA et al. (1996) mostra que a adição de baixos teores (até $2 \%$ em relação ao peso de agregado) de partículas muito finas de borracha (passando na peneira \#200, de abertura $0,075 \mathrm{~mm}$ ) não apresentou efeito significativo sobre o teor ótimo de asfalto e nas propriedades volumétricas de uma mistura asfáltica densa. As pesquisas também mostram que, em misturas não envelhecidas, a incorporação de partículas de borracha pelo processo seco tende a reduzir a rigidez da mistura resultante, quando comparado ao processo úmido de incorporação de borracha. Em misturas envelhecidas, a adição de borracha triturada aumenta a 
resistência à deformação permanente em relação à mistura de controle. Entretanto, a adição de maiores teores de borracha (acima de 2\%) pode levar à redução da resistência à deformação permanente.

O módulo de resiliência e a resistência à tração de misturas utilizando o processo seco geralmente diminuem com o aumento da quantidade de borracha (EATON et al, 1991; GOWDA et al., 1996). Misturas com borracha de graduação mais fina apresentam maior módulo de resiliência e menor vida de fadiga quando comparadas às misturas que contém borracha de graduação mais grossa (TAKALLOU et al., 1986).

Outros estudos apresentam resultados animadores quando são utilizadas partículas menores de borracha no processo seco. REBALA \& ESTAKHRI (1995) obtiveram bons resultados de laboratório, indicando o bom desempenho (em termos de deformação permanente) de misturas que contém baixa concentração de borracha $(0,5 \%$ em peso de agregado). Neste caso foram utilizadas duas granulometrias de borracha: a borracha "grossa" (passada na peneira \#10, de abertura 2,00 mm) e borracha "fina" (passada na peneira $\# 80$, de abertura $0,177 \mathrm{~mm}$ ). Os autores também constataram que as misturas não apresentaram problemas de adesividade, sendo pouco suscetíveis à umidade.

HEITZMAN (1992) cita a construção de trechos experimentais em Nova Iorque e Flórida, onde foram utilizadas partículas de borracha passando na peneira \#10 (2,00 mm) e \#80 (0,177 mm), respectivamente. EMERY (1995) comenta sobre o desempenho de curto prazo de trechos experimentais construídos em Ontário: misturas que incorporaram 1,5\% de borracha passando na peneira \#10 (processo seco) têm apresentado desempenho similar ao da mistura de controle. 
Existem evidências de que misturas de granulometria densa, onde são incorporadas partículas mais finas e em menores teores, apresentam melhor desempenho. Entretanto, é importante considerar que essas "evidências" são válidas para misturas preparadas em países com condições climáticas e de materiais completamente diversas das encontradas no Brasil. Por exemplo, nos Estados Unidos a amplitude de temperaturas é muito grande: algumas regiões sofrem inverno rigoroso, com vários meses de neve, e têm um verão também muito intenso. Conseqüentemente, o pavimento é muito solicitado: precisa suportar o inverno sem trincar e o verão sem acumular muita deformação permanente nas trilhas de roda.

Quanto aos agregados pétreos, alguns estados americanos chegam a importar material do Canadá. Utilizam bastante rochas calcáreas como agregados (massa específica de 2,25). No Brasil, por outro lado, temos basaltos, granitos e gnaisses que, de modo geral, apresentam propriedades físico-químicas e mecânicas muito melhores. Portanto, a revisão bibliográfica é importante para apontar as diretrizes, mas a pesquisa tem que se adequar à realidade brasileira.

HEITZMAN (1992) destaca outros dois importantes aspectos relacionados à construção de pavimentos asfálticos modificados com borracha: a possibilidade da reciclagem desses pavimentos e a necessidade de avaliação dessas misturas no campo para estabelecer níveis de desempenho esperados. Este aspecto da tecnologia é crucial para sua aplicação em longo prazo: se os pavimentos modificados não puderem ser reciclados, seu benefício é substancialmente reduzido e um novo problema de resíduos é criado.

Segundo BAKER \& CONNOLLY (1995), em 1991, no estado americano de Nova Jersey, foi construído um trecho utilizando o sistema PlusRide ${ }^{\circledR}$, que desintegrou logo após a construção. $\mathrm{O}$ revestimento asfáltico foi fresado e 
classificado em diferentes frações granulométricas. Esse material foi reciclado, substituindo $20 \%$ dos agregados necessários à fabricação de uma nova mistura. Dados de emissões atmosféricas mostraram que os padrões de qualidade do ar não foram excedidos durante a reciclagem.

TAKALLOU \& SAINTON (1992) também confirmam a possibilidade da reciclagem para esse tipo de material. Resultados das análises de emissões atmosféricas durante a usinagem de misturas modificadas com adição de borracha foram idênticos aos obtidos em misturas convencionais.

Ainda assim, a escassez de informações salienta a necessidade de estudos adicionais sobre a potencialidade de reciclagem das misturas asfálticas modificadas com borracha e os impactos ambientais durante a produção dessas misturas.

\subsection{4 - Análise Econômica}

Há várias barreiras que dificultam a adoção dos sistemas de incorporação de borracha de pneus nas misturas asfálticas: necessidade de equipamentos especiais, particularidades na granulometria dos agregados pétreos, falta de padronização de critérios de dosagem e avaliação das misturas, custo da borracha triturada e uso de processos patenteados. Tanto no processo úmido quanto no seco, essas dificuldades combinadas resultam no principal problema quanto ao uso da borracha de pneu: o alto custo das misturas que contém borracha quando comparado ao custo das misturas convencionais (TAKALLOU \& SAINTON, 1992). 
Análise econômica realizada por McQUILLEN et al. (1988) mostra que a construção de pavimentos asfálticos utilizando o processo seco de incorporação pode ser viável. Esta conclusão foi baseada na análise dos custos durante a vida em serviço dos pavimentos. A análise estrutural (considerando curvas de fadiga e módulos de resiliência obtidos em laboratório) permitiu analisar a influência da borracha na espessura do revestimento asfáltico: para as misturas modificadas, pode-se obter uma redução de 20 a 40\% na espessura do revestimento em relação a uma mistura asfáltica convencional. McQUILLEN et al. (1988) também ressaltam outros benefícios das misturas modificadas em relação às misturas convencionais, benefícios estes mais difíceis de serem quantificados, como o aumento da resistência à derrapagem (aumento do coeficiente de atrito superficial), a redução do nível de ruído no contato pneu-pavimento e os "ganhos" ambientais ao se evitar a disposição inadequada de pneus inservíveis. 


\section{5 - Programa EXPERIMENTAL}

\section{1 - INTRODUÇÃo}

Existem vários métodos para planejar e conduzir um experimento. Os experimentos fatoriais são usados quando se tem por objetivo estudar a influência de diversos fatores sobre um fenômeno. Fatores são todas as grandezas cuja variação pode afetar o resultado de um experimento. São chamados de níveis de um fator os diversos valores que estes podem assumir.

$\mathrm{Na}$ experimentação clássica, o pesquisador investiga os efeitos de cada fator separadamente, mantendo constante todos os outros fatores, e verifica as variações do fenômeno resultante da variação desse fator. A maior desvantagem desse tipo de experimento está no fato de não considerar qualquer possibilidade de interação entre os fatores.

Nos experimentos fatoriais, os efeitos de vários fatores são investigados simultaneamente. São consideradas todas as possibilidades possíveis de combinação entre os diferentes fatores. Conforme destacam COCHRAN \& COX (1962), os experimentos fatoriais apresentam nítidas vantagens sobre os métodos tradicionais pois, com um menor número de ensaios, fornecem o mesmo nível de informação sobre os fatores individuais e analisam também as interações entre os fatores, evitando assim que sejam tiradas conclusões errôneas. 
Considerando a revisão bibliográfica, são inúmeros os fatores que afetam o desempenho dos pavimentos, sendo praticamente impossível a consideração simultânea de todos eles em uma mesma programação fatorial. Estudos conduzidos por TAKALLOU et al. (1986) e GALLEGO et al. (2000) indicam que fatores como tipo, tamanho e graduação da borracha, quantidade de borracha, graduação do agregado pétreo, teor de vazios e tempo de digestão, entre outros, influem de modo considerável no desempenho dos concretos asfálticos. Este trabalho analisa como alguns desses fatores (julgados os mais importantes) influem nas propriedades mecânicas das misturas asfálticas modificadas com adição de borracha de pneus.

A Figura 17 apresenta um diagrama de blocos esquematizando o roteiro experimental completo desenvolvido neste trabalho.

Caracterização e Preparação dos Materiais: CAP-20, Borracha e Agregado Pétreo

\begin{tabular}{|c|c|c|c|}
\hline \multicolumn{3}{|c|}{ Ensaios Exploratórios } & \\
\hline \begin{tabular}{|l} 
- Borracha: G \\
Investigações: \\
- Substituição do agregado \\
pela borracha \\
- Máximo teor de borracha \\
Ensaios: \\
- Marshall \\
- Creep estático \\
\end{tabular} & 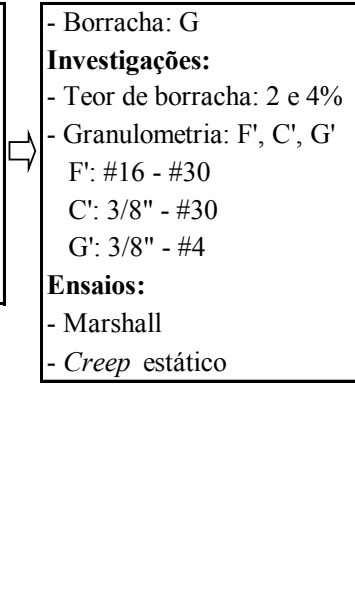 & \begin{tabular}{|l} 
- Borracha: F e G \\
F: \#16 - \#100 \\
G: $3 / 8 "$ - \#30 \\
- Teor de Borracha: 2\% \\
Investigação: \\
- Envelhecimento curto-prazo \\
(tempo de digestão) \\
Ensaios: \\
- Resistência à tração \\
- Módulo de resiliência \\
Investigação: \\
- Teor de ligante (Vv $=4 \%$ ) \\
Ensaios: \\
- Marshall \\
- Trilha de roda em \\
simulador de tráfego
\end{tabular} & 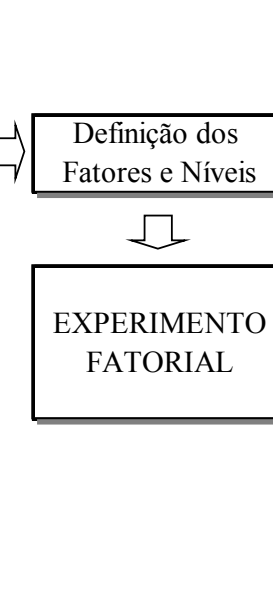 \\
\hline
\end{tabular}

FIGURA 17 - Programação da investigação laboratorial. 
A utilização de um material não convencional faz com que a programação dos ensaios tenha de ser ajustada através da exclusão ou da inclusão de fatores e níveis adicionais na medida em que os resultados vão sendo obtidos. $\mathrm{Na}$ fase chamada de "ensaios exploratórios" procurou-se eliminar alguns desses fatores e níveis, diminuindo assim uma parte da já grande quantidade de ensaios.

Numa primeira fase dos ensaios exploratórios, procurou-se analisar qual o limite máximo para o teor de borracha a ser incorporado e como fazer a substituição do agregado pétreo por borracha. Verificou-se a possibilidade de obtenção de misturas modificadas pelo processo seco, utilizando borracha com teor e granulometria maiores que as descritas na literatura. As "respostas" nesta fase inicial foram obtidas dos resultados dos ensaios Marshall e de fluência por compressão uniaxial estática (creep estático).

$\mathrm{Na}$ última etapa dos ensaios exploratórios procurou-se investigar os fatores tempo de digestão e teor de ligante. $\mathrm{Na}$ fase de dosagem, as misturas de controle e preparadas com $2 \%$ de borracha (em relação ao peso da mistura) nas granulometrias grossa $(G)$ e fina $(F)$ foram submetidas a uma simulação de envelhecimento em estufa, anteriormente à compactação, por períodos de 0,2 e 4 horas a $150^{\circ} \mathrm{C}$. Procurou-se analisar o efeito do tempo de digestão e da granulometria da borracha sobre as propriedades volumétricas das misturas.

Misturas preparadas com $2 \%$ de borracha nas granulometrias F e G, dosadas para a obtenção de um volume de vazios de 4\% (valor usualmente recomendado na literatura técnica), foram submetidas ao ensaio de afundamento em trilha de roda em equipamento simulador de tráfego em laboratório. Essas misturas apresentaram deformação permanente excessiva, indicando que os teores de ligante utilizados foram extremamente elevados para essas misturas. 
Procurou-se analisar o efeito do tempo de digestão através da determinação do módulo de resiliência e da resistência à tração em misturas virgens (moldagem imediata) e submetidas à simulação de envelhecimento em estufa (2 horas a $150^{\circ} \mathrm{C}$ ) antes da compactação. Os resultados dos ensaios indicaram que o tempo de digestão parece melhorar as propriedades mecânicas das misturas modificadas.

Desse modo, com base nas informações obtidas nos ensaios exploratórios, optou-se por não considerar os fatores teor de ligante e tempo de digestão no planejamento fatorial. Todas as misturas neste trabalho foram moldadas considerando-se o envelhecimento de curto prazo e utilizando a mesma quantidade de ligante adicionada à mistura de controle para a obtenção de um teor de vazios de 4\%. A Tabela 22 apresenta os fatores e níveis considerados no planejamento dos experimentos.

TABELA 22 - Fatores e níveis considerados no experimento.

\begin{tabular}{lc}
\hline Fatores & Níveis \\
\hline \multirow{2}{*}{ Granulometria da Borracha } & Grossa (G) \\
\hline \multirow{2}{*}{ Teor de Borracha $^{*}$} & Fina (F) \\
& $1 \%$ \\
\hline
\end{tabular}

${ }^{*}$ Porcentagem de borracha em relação à massa total da mistura

Para caracterizar as misturas asfálticas estudadas foram preparadas amostras com duas granulometrias de borracha, uma grossa $(\mathrm{G})$ e outra fina $(\mathrm{F})$, substituindo parte dos agregados pétreos em algumas frações da curva granulométrica. Utilizaram-se quantidades de borracha equivalentes a 1 e $2 \%$ do peso total da mistura. Essas misturas foram comparadas a uma mistura convencional, sem borracha (mistura de controle). 
Procurou-se analisar os efeitos da quantidade e granulometria da borracha sobre o módulo de resiliência e a resistência à tração. $\mathrm{O}$ ensaio Cântabro foi considerado na tentativa de verificação da resistência à desagregação/desgaste. A avaliação da capacidade das misturas em resistir às deformações permanentes foi feita através do ensaio de trilha de roda em equipamento simulador de tráfego em laboratório.

A Figura 18 apresenta o método de trabalho utilizado nos experimentos realizados.

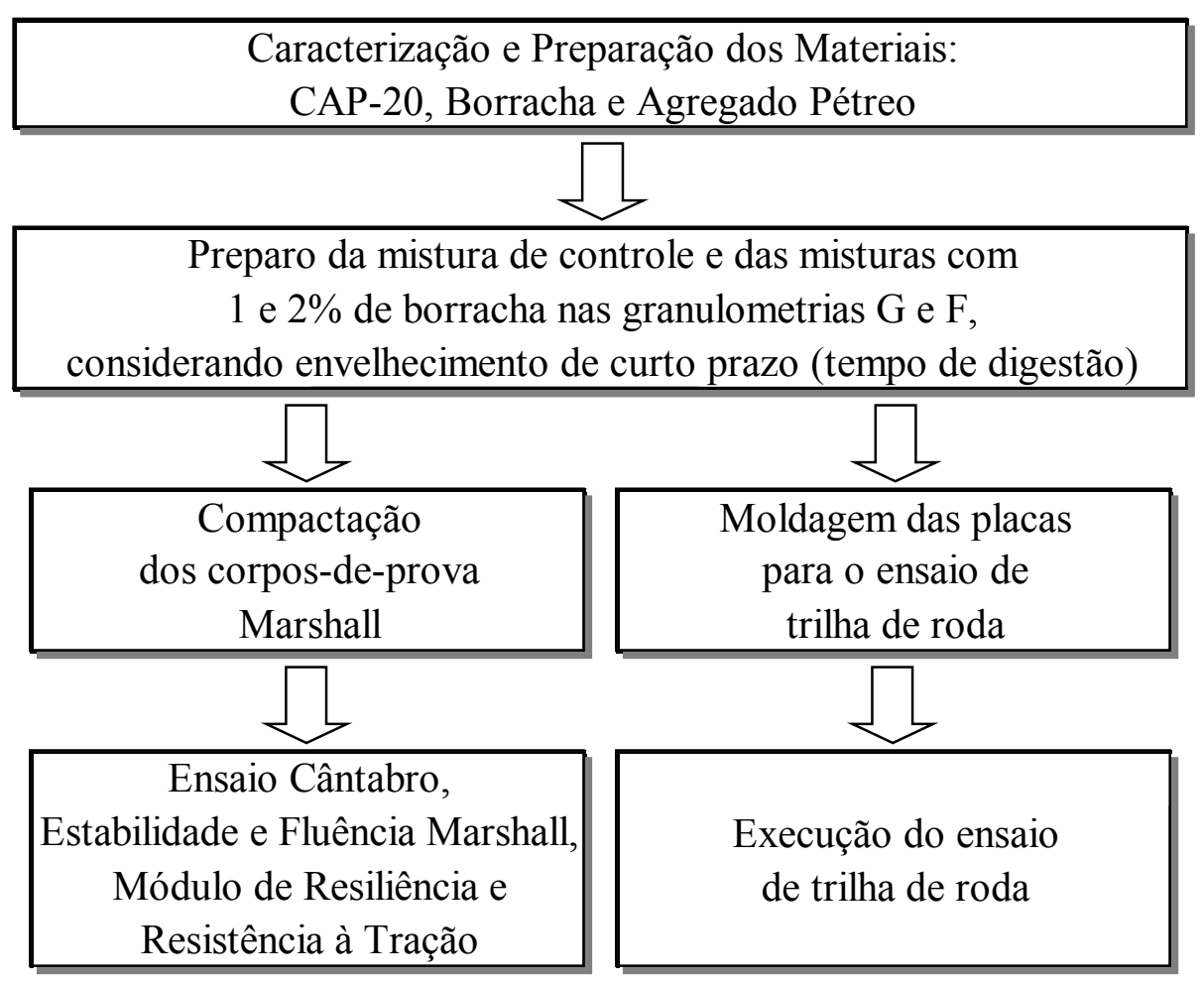

FIGURA 18 - Diagrama de blocos do método de trabalho experimental. 


\section{2 - Materiais Utilizados}

\subsection{1 - Borracha de Pneu}

A borracha utilizada nessa pesquisa foi fornecida pela BORCOL Indústria de Borracha Ltda., sendo obtida da trituração de pneus "novos" de ônibus e caminhões, que não foram aprovados no controle de qualidade das indústrias de pneumáticos. As propriedades físicas da borracha fornecida pela BORCOL são apresentadas na Tabela 23.

TABELA 23 - Propriedades físicas da borracha fornecida pela BORCOL.

\begin{tabular}{|c|c|c|}
\hline Características & Especificação & Resultados \\
\hline Cor & Preta & \\
\hline Forma Física & Partículas & \\
\hline Extrato Acetônico ${ }^{1}$ 16h (\%) & Máx. 20 & 17,07 \\
\hline $\operatorname{Cinzas}^{2} 8$ horas a $55^{\circ} \mathrm{C}$ & Máx. 10 & 5,6 \\
\hline Negro-de-fumo ${ }^{3}$ & Mín. 28 & 29,15 \\
\hline Hidrocarbonetos ${ }^{4}$ & Mín. 45 & 48,18 \\
\hline
\end{tabular}

${ }^{1}$ Acetone Extraction Test (ASTM D 297)

${ }^{2}$ Ash Content Test (ASTM D 297)

${ }^{3}$ Carbon Black Test (Nitric Acid Digestion Method - ASTM D 1515)

${ }^{4}$ Hidrocarboneto (\%) = 100 - cinzas (\%) - extrato acetônico (\%) - negro-de-fumo (\%)

A borracha é obtida através de equipamentos que trituram o pneu à temperatura ambiente. O processo da redução das partículas se realiza através de um sistema de rosca sem fim, onde a borracha é transportada até a linha de moedores, sendo triturada até atingir a granulação desejada. A separação das impurezas se repete a cada etapa das sucessivas moagens: o aço é removido através de separação magnética e o tecido é removido através de um sistema de sucção. 
Foram utilizadas duas granulometrias de borracha triturada: uma denominada "G" (grossa), contendo partículas com diâmetros variando de 9,5 mm (3/8") até $0,60 \mathrm{~mm}$ (\#30) e outra, denominada "F" (fina), contendo partículas com diâmetros variando de 1,18 $\mathrm{mm}$ (\#16) até 0,15 mm (\#100).

Para a análise visual do formato e textura das partículas, fez-se a ampliação em microscópio óptico acoplado a um analisador de imagens, no Laboratório de Caracterização Tecnológica do Departamento de Engenharia de Minas da Escola Politécnica da USP - Figuras 19, 20, 21 e 22.
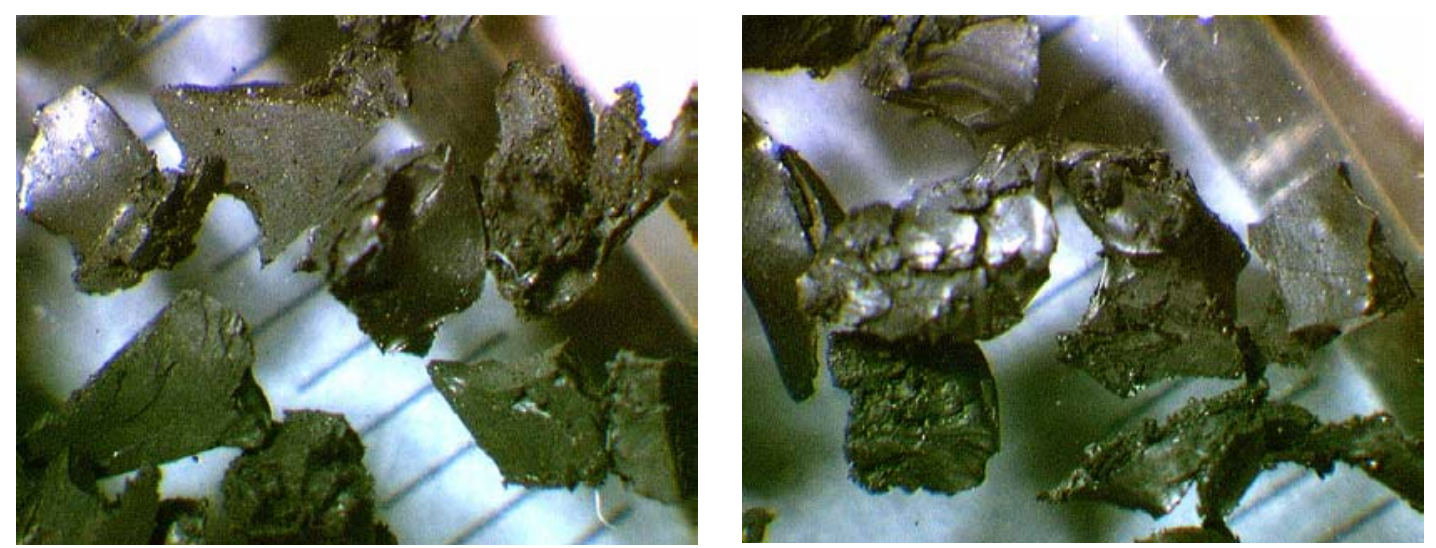

FIGURA 19 - Partículas de borracha na granulometria G (fração: \#8 - \#16).
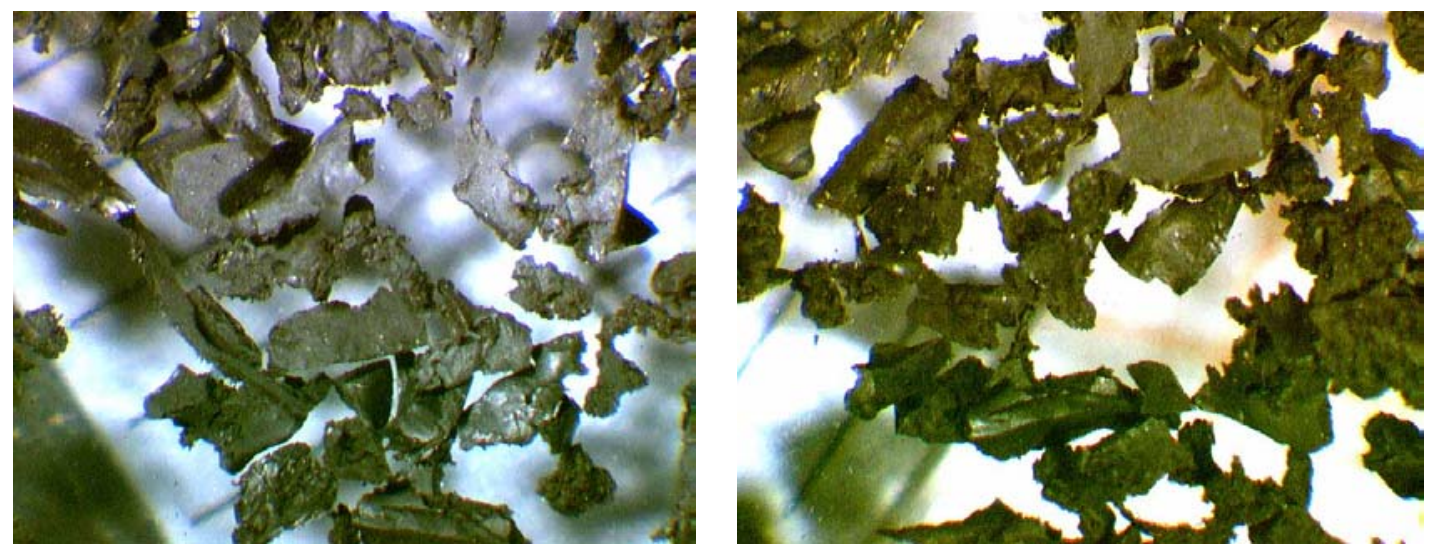

FIGURA 20 - Partículas de borracha na granulometria G (fração: \#16 - \#30). 

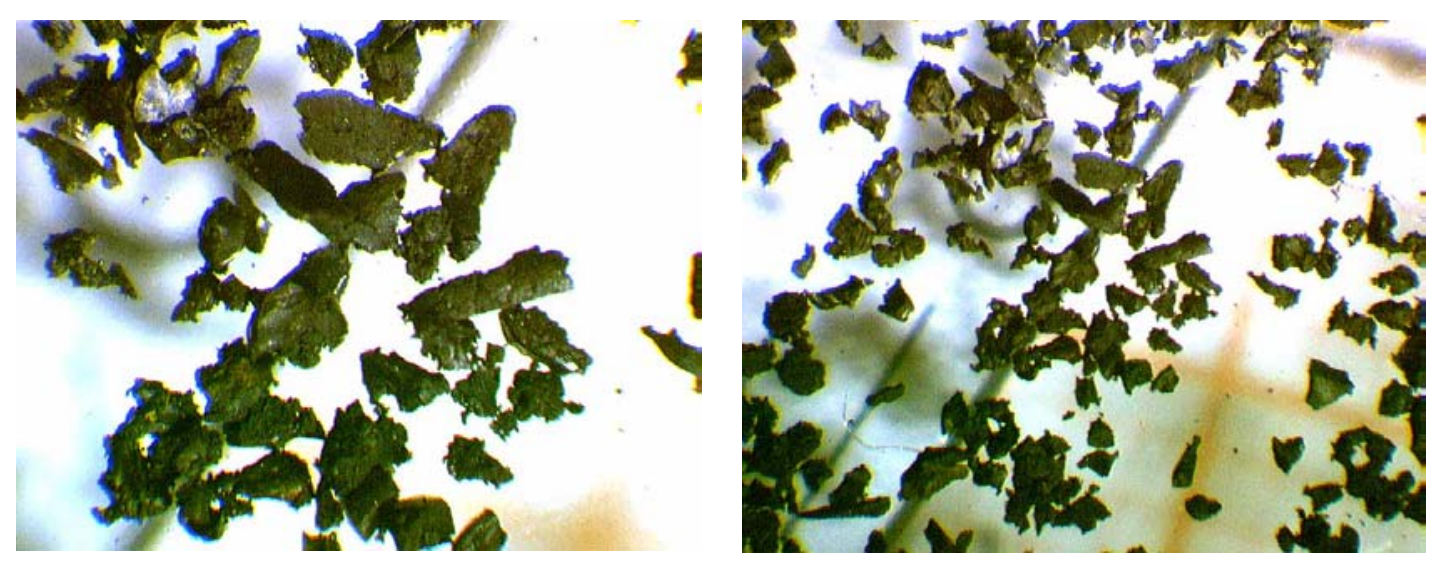

FIGURA 21 - Partículas de borracha na granulometria F (fração: \#30 - \#50).
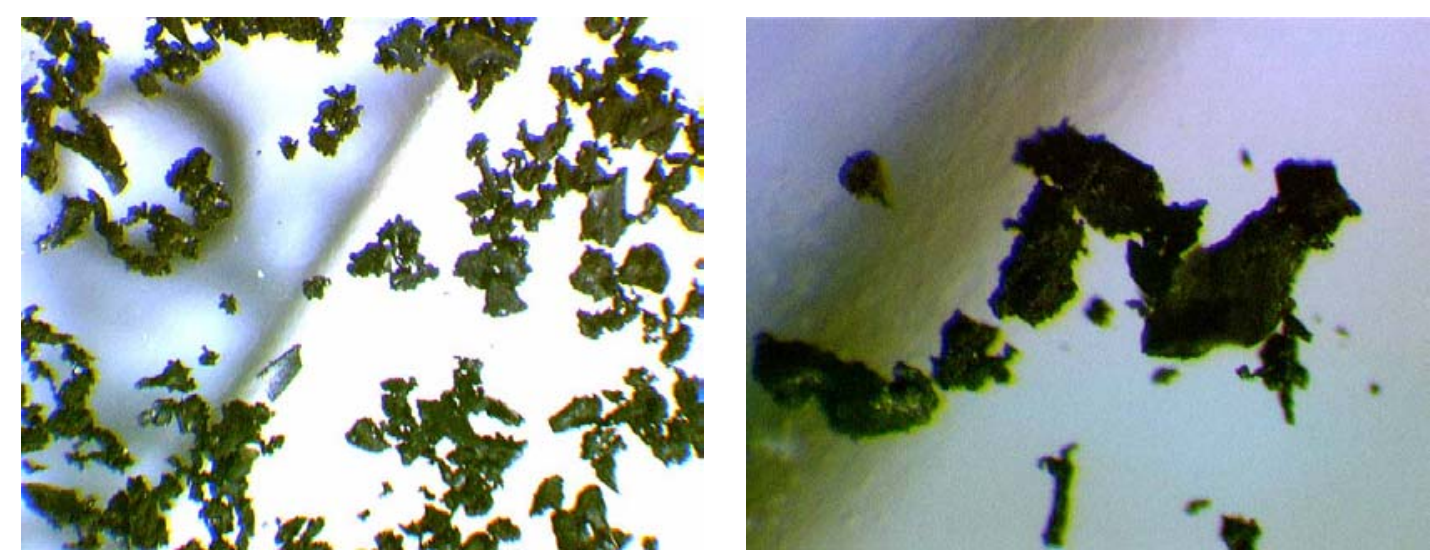

FIGURA 22 - Partículas de borracha na granulometria F (fração: \#50 - \#100).

As partículas de borracha grossa (G) nas frações \#8 - \#16 e \#16 - \#30 (Figuras 19 e 20) apresentam formato irregular e superfície rugosa. As partículas de borracha fina (F) nas frações \#30 - \#50 e \#50 - \#100 (Figuras 21 e 22) apresentam formato irregular e tamanho bastante variado, com a presença de partículas bem menores, mostrando que houve falhas no processo de peneiramento. As ampliações não foram suficientes para permitir a visualização de poros nas partículas. 
A borracha triturada foi caracterizada por ensaios de densidade real das partículas (obtida por picnometria de hélio), porosidade (em mercúrio) e análise termogravimétrica (TGA). Os ensaios foram realizados no Centro de Caracterização e Desenvolvimento de Materiais (CCDM), na Universidade Federal de São Carlos. A Tabela 24 apresenta os resultados de densidade real, análise termogravimétrica e porosidade para duas frações de borracha.

TABELA 24 - Características da borracha utilizada.

\begin{tabular}{l|c|c|c|c}
\hline \multirow{2}{*}{ Ensaio } & \multicolumn{4}{|c}{ Material } \\
\cline { 2 - 5 } & $\mathbf{3 / 8}$ - $\# \mathbf{4}$ & $\# \mathbf{1 6}-\# \mathbf{3 0}$ & $\# \mathbf{1 6}-\# \mathbf{3 0}$ & $\# \mathbf{5 0}-\# \mathbf{1 0 0}$ \\
\hline $\begin{array}{l}\text { Massa específica } \\
\left(\mathrm{g} / \mathrm{cm}^{3}\right)\end{array}$ & $1,1334 \pm 0,0010$ & $1,1547 \pm 0,0007$ & $1,1607 \pm 0,0016$ & $1,1934 \pm 0,0012$ \\
\hline $\begin{array}{l}\text { Perda de massa a } \\
170^{\circ} \mathrm{C}(\%)\end{array}$ & 0,7410 & 0,7877 & - & 0,6025 \\
\hline $\begin{array}{l}\text { Porosidade em } \\
\text { mercúrio (\%) }\end{array}$ & 9,65 & 16,08 & - & 68,94 \\
\hline
\end{tabular}

A análise termogravimétrica (TGA) permite que sejam analisadas as mudanças no peso da amostra, resultante de transformações químicas ou físicas em função da temperatura (taxa de aquecimento) ou intervalo de tempo. Empregou-se uma taxa de aquecimento de $10^{\circ} \mathrm{C} / \mathrm{min}$., no intervalo de temperatura de 50 a $600^{\circ} \mathrm{C}$.

As amostras de borracha mais grossa (G) apresentaram uma perda de massa, em função da liberação dos óleos voláteis do pneu, de $0,7410 \%$ a $0,7877 \%$, em torno de $170^{\circ} \mathrm{C}$, enquanto a borracha mais fina $(\mathrm{F})$ apresentou uma perda de massa de $0,6025 \%$ a $170^{\circ} \mathrm{C}$.

A Figura 23 apresenta os gráficos de porosidade em função do diâmetro das partículas. 


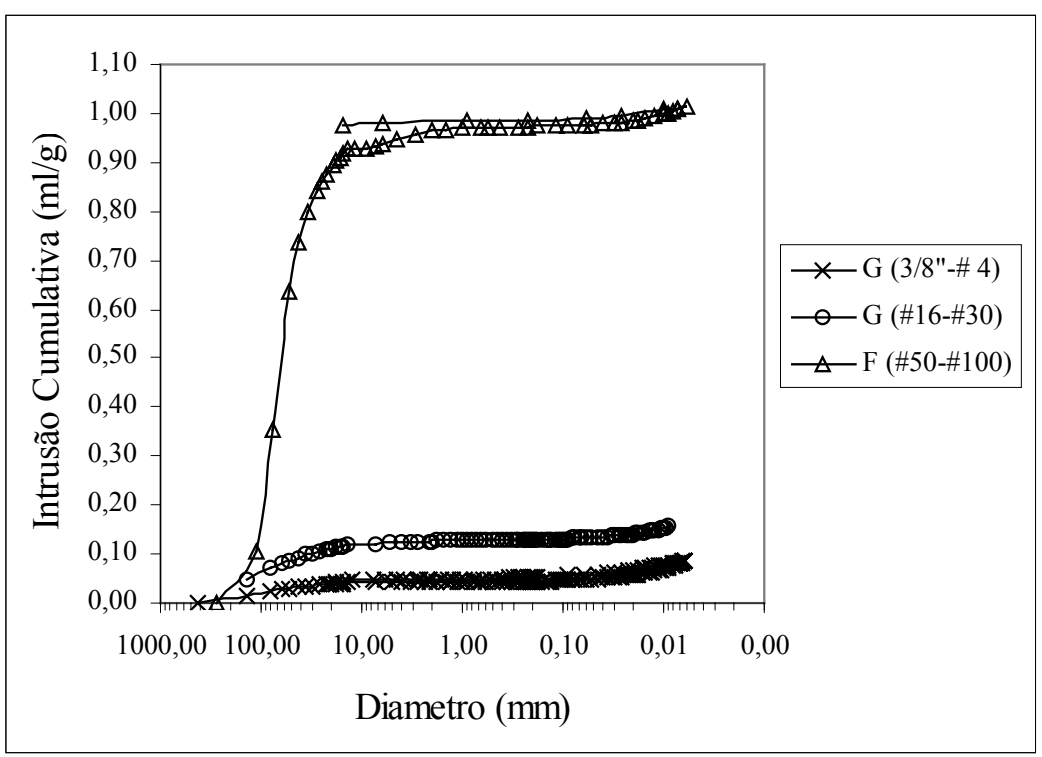

(a) Borracha nas granulometrias $\mathrm{G}$ e $\mathrm{F}$

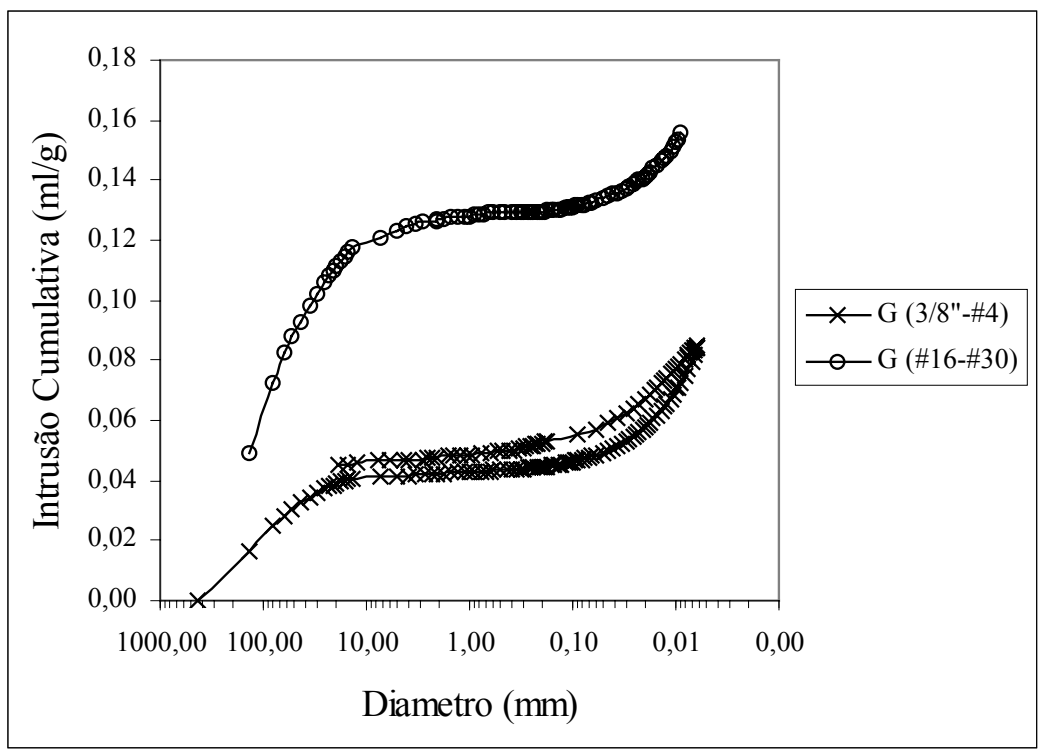

(b) Borracha na granulometria $\mathrm{G}$

FIGURA 23 - Porosidade em mercúrio para três frações de borracha.

Da análise dos resultados do ensaio de porosimetria em mercúrio verifica-se que as curvas não foram terminadas devido ao fundo de escala do equipamento (pressão máxima de 30.000 psi). Para as partículas mais finas do pó de borracha (\#50 - \#100) observa-se a presença de apenas uma população de poros da ordem de $60 \mu \mathrm{m}$. As frações mais grossas apresentam duas 
populações de poros: $80 \mu \mathrm{m}$ e $0,02 \mu \mathrm{m}$ para a fração $3 / 8$ " - \#4 e $70 \mu \mathrm{m}$ e $0,02 \mu \mathrm{m}$ para a fração \#16 - \#30. Pode-se concluir que, com a diminuição das partículas de borracha, estas passam a apresentar maior área superficial e maior porosidade superficial aberta, o que leva ao aumento do volume de mercúrio utilizado no ensaio. O Apêndice 2 contém os termogramas e os resultados completos dos ensaios de porosimetria obtidos para as três frações de borracha.

\subsection{2 - Agregado Pétreo}

Utilizou-se agregado britado, de natureza basáltica, proveniente da Pedreira Inderp localizada na Rodovia Antonio Machado Sant'ana, SP 255, km 7, município de Ribeirão Preto - SP. O fíler utilizado foi extraído por peneiramento a seco do pó-de-pedra oriundo da pedreira mencionada. A Tabela 25 apresenta algumas das propriedades dos agregados pétreos utilizados.

TABELA 25 - Características dos agregados pétreos utilizados.

\begin{tabular}{l|c|c}
\hline \multirow{2}{*}{ Ensaio } & \multicolumn{2}{|c}{ Agregado } \\
\cline { 2 - 3 } & \multicolumn{2}{|c}{ Graúdo } \\
\hline $\begin{array}{l}\text { Desgaste de agregado por } \\
\text { Abrasão Los Angeles (\%) }\end{array}$ & \multicolumn{2}{|c}{$14,1(\leq 40)$} \\
\hline Densidade Real das Partículas & \multicolumn{2}{|c}{2,858} \\
\hline Adesividade & \multicolumn{2}{|c}{ Não satisfatória } \\
\hline
\end{tabular}

Os ensaios de adesividade para agregados graúdos e miúdos apresentaram resultado não satisfatório para o agregado utilizado. Esses métodos não apresentam correlação com o que acontece no campo, podendo resultar em resultados enganosos. Assim, foram realizados ensaios complementares 
utilizando misturas compactadas (ensaio de umidade induzida - AASHTO T283). O resultado, apresentado no capítulo 6 - item 6.7, indicou que a mistura compactada não apresenta problemas de adesividade entre agregado e ligante.

Trabalhou-se com uma granulometria correspondente ao centro da faixa " $\mathrm{C}$ " do DNER (1997) adaptada às especificações SUPERPAVE ${ }^{\circledR}$ (FHWA, 1995), conforme Figura 24. O diâmetro máximo nominal é de 12,5 mm.

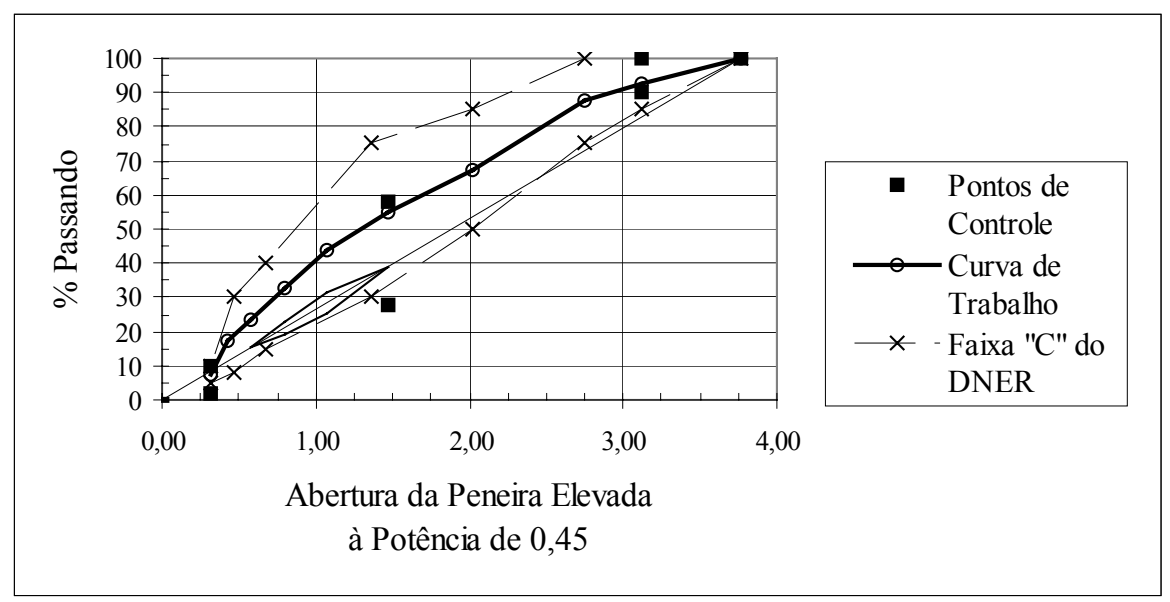

(a) Curva granulométrica em diagrama de potência 0,45 (conforme especificação SUPERPAVE ${ }^{\circledR}$ )

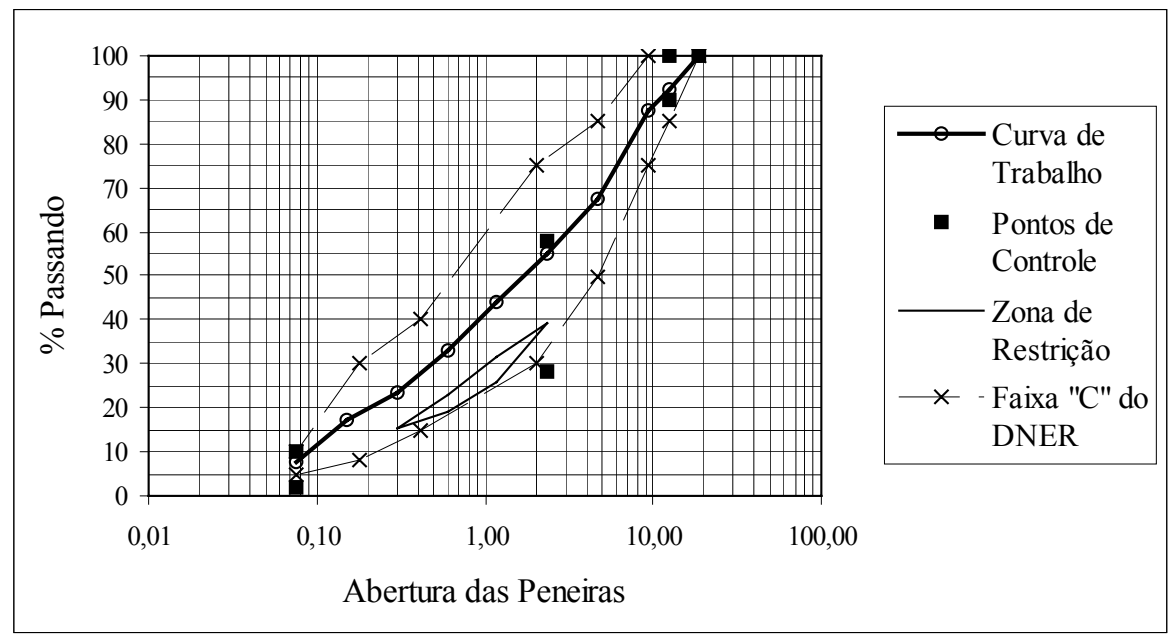

(b) Curva granulométrica em escala logarítmica

FIGURA 24 - Curva granulométrica da mistura estudada. 


\subsection{3 - Ligante Asfáltico}

O ligante asfáltico utilizado foi o CAP-20 por ser um material de uso rotineiro e comercialmente disponível em todo o Brasil. As propriedades do CAP-20 utilizado são apresentadas na Tabela 26, conforme caracterização feita pelo Instituto de Pesquisas Tecnológicas de São Paulo (IPT).

TABELA 26 - Propriedades do CAP-20 utilizado no preparo das misturas.

\begin{tabular}{|c|c|c|c|c|}
\hline \multicolumn{2}{|l|}{ Ensaio } & Resultado & $\begin{array}{l}\text { Exigência } \\
\text { DNC 01/92 }\end{array}$ & Método \\
\hline \multicolumn{2}{|c|}{ Viscosidade absoluta a $60^{\circ} \mathrm{C}$ (poise) } & 3317 & 2000 a 3500 & NBR 5847 \\
\hline \multicolumn{2}{|c|}{ Viscosidade Saybolt Furol a $135^{\circ} \mathrm{C}(\mathrm{s})$} & 180 & 120 mín. & \multirow{2}{*}{ MB-517 } \\
\hline \multicolumn{2}{|c|}{ Viscosidade Saybolt Furol a $177^{\circ} \mathrm{C}(\mathrm{s})$} & 30,3 & 30 a 150 & \\
\hline \multirow{3}{*}{$\begin{array}{l}\text { Efeito do } \\
\text { Calor e } \\
\text { do Ar }\end{array}$} & Variação em massa (\%) & 0,044 & 1,0 máx. & MB-425 \\
\hline & Relação de viscosidade & 1,7 & 4,0 máx. & - \\
\hline & Ductilidade a $25^{\circ} \mathrm{C}(\mathrm{cm})$ & $>100$ & 20 mín. & NBR 6293 \\
\hline \multicolumn{2}{|c|}{ Índice de suscetibilidade térmica } & $-1,0$ & $-1,5$ a 1,0 & - \\
\hline \multicolumn{2}{|c|}{ Penetração, $25^{\circ} \mathrm{C}, 100 \mathrm{~g}, 5 \mathrm{~s}(0,1 \mathrm{~mm})$} & 59 & 50 mín. & NBR 6576 \\
\hline \multicolumn{2}{|c|}{ Ponto de fulgor $\left({ }^{\circ} \mathrm{C}\right)$} & 300 & 235 mín. & NBR 11341 \\
\hline \multicolumn{2}{|c|}{ Solubilidade em tricloroetileno ( $\%$ em massa) } & 99,7 & 99,5 mín & MB-166 \\
\hline
\end{tabular}

\subsection{4 - Misturas}

Procurou-se incorporar a borracha buscando manter o mesmo arranjo granulométrico da mistura de controle. Para tanto, criou-se uma lacuna na curva granulométrica do agregado pétreo (excluindo parte dos agregados) para possibilitar a adição da borracha triturada. Na substituição, considerou-se que a borracha triturada possui formato semelhante ao agregado pétreo e, portanto, mesma área superficial. Deste modo, o ajuste na granulometria do agregado pétreo considerou apenas os pesos específicos da borracha e do agregado através das equações: 


$$
\begin{gathered}
\mathrm{M}_{\text {agreg.excluído }}=\mathrm{M}_{\text {borr.entra }} \frac{\bar{\rho}_{\text {agreg. }}}{\bar{\rho}_{\text {borr. }}} \Rightarrow \\
\Rightarrow \mathrm{M}_{\text {agreg.excluído }}=\mathrm{M}_{\text {borr.entra }} \times 2,50(\text { para a borracha } \mathrm{G}) \\
\Rightarrow \mathrm{M}_{\text {agreg.excluído }}=\mathrm{M}_{\text {borr.entra }} \times 2,43(\text { para a borracha } \mathrm{F})
\end{gathered}
$$

As duas granulometrias de borracha ( $\mathrm{G}$ e $\mathrm{F}$ ) foram distribuídas na curva granulométrica dos agregados pétreos acompanhando a faixa $\mathrm{C}$ do DNER, conforme Figura 25. A Tabela 27 apresenta a composição granulométrica das misturas estudadas.

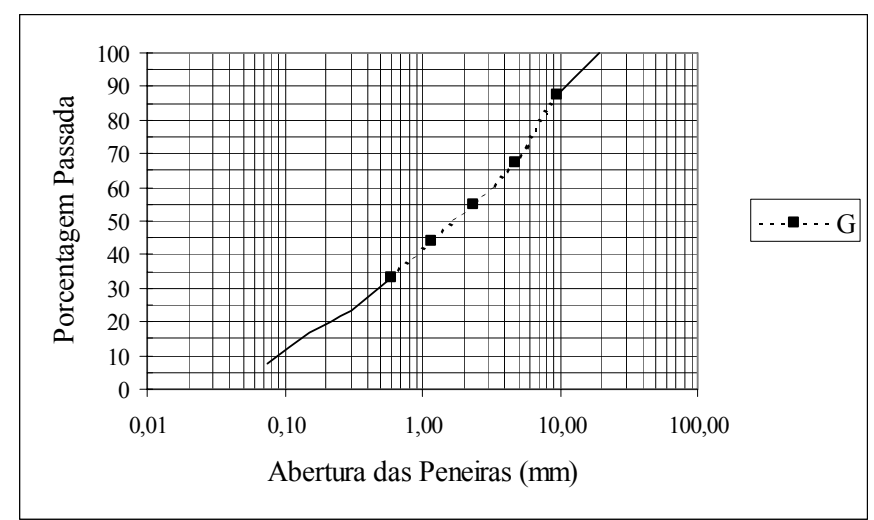

(a) Mistura com borracha na granulometria G: 9,5 mm até $0,60 \mathrm{~mm}(3 / 8 "-\# 30)$

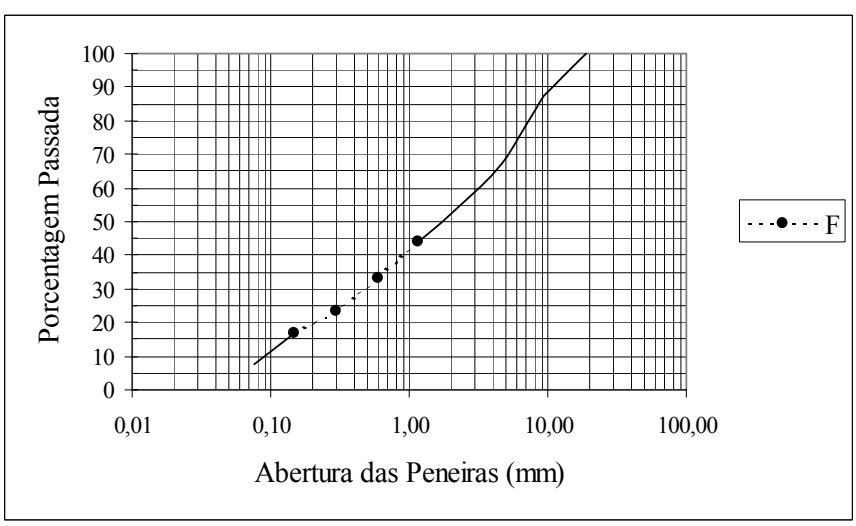

(b) Mistura com borracha na granulometria F: 1,18 mm até 0,15 mm (\#16-\#100)

FIGURA 25 - Frações granulométricas onde foram incorporadas as amostras de borracha $\mathrm{G}$ e $\mathrm{F}$. 


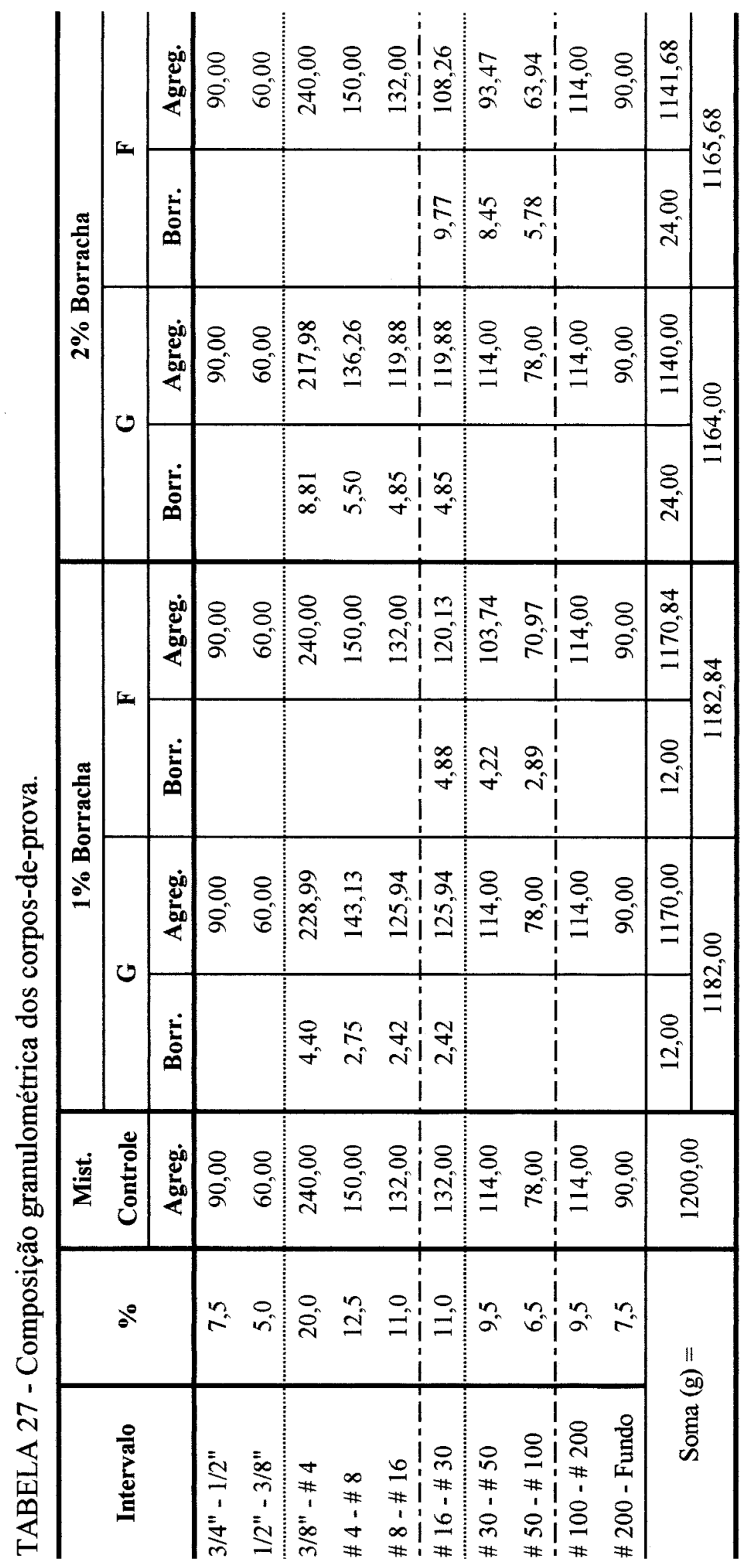




\section{3 - MÉTOdos DE ENSAIO}

\subsection{1 - Introdução}

Inicialmente foram realizados os ensaios de solubilização e lixiviação, com o objetivo de classificar as amostras (somente borracha, mistura asfáltica convencional e misturas asfálticas utilizando borracha como agregado) através da detecção de metais pesados. Buscou-se verificar se a disposição de borracha triturada (diminuição de volume) em aterros poderia causar algum dano ao meio ambiente e se a incorporação dessa borracha nas misturas asfálticas poderia resultar em um produto menos agressivo.

Os ensaios utilizados na avaliação de propriedades diretamente relacionadas com o desempenho das misturas asfálticas foram:

- Método Marshall para determinação de estabilidade e fluência;

- Ensaio de compressão diametral cíclico por cargas repetidas para determinação do módulo de resiliência;

- Determinação da resistência à tração por compressão diametral;

- Ensaio de simulação de tráfego em laboratório para avaliação da resistência à deformação permanente.

A durabilidade de um pavimento pode ser afetada pelo envelhecimento de curto e longo prazo e pela adesividade entre agregados e ligante asfáltico na presença de umidade. $\mathrm{O}$ envelhecimento e os problemas de adesividade não são considerados como defeitos com a mesma conotação da deformação permanente e do trincamento por fadiga. Estes são fatores que alteram as propriedades da mistura, podendo ser a causa indireta de um defeito. Para a avaliação da adesividade agregado-ligante, foi realizado o ensaio de umidade induzida (AASHTO T-283/89). Quanto ao envelhecimento de curto prazo, 
procurou-se analisar se a adição de borracha pode influenciar positivamente no desempenho das misturas asfálticas.

O problema do desgaste também está relacionado à durabilidade das misturas asfálticas. Para a avaliação da resistência à desintegração foi utilizado o ensaio espanhol Cântabro de perda de massa por desgaste.

Os ensaios para avaliação das propriedades mecânicas e da durabilidade das misturas asfálticas foram realizados no Laboratório de Tecnologia de Pavimentação do Departamento de Transportes da Escola Politécnica da USP, em São Paulo (LTP/EPUSP).

\subsection{2 - Solubilização e Lixiviação}

A CETESB - Companhia de Tecnologia de Saneamento Ambiental exige, para fins de construção de pistas experimentais, que misturas asfálticas preparadas com borracha de pneus não apresentem riscos potenciais ao meio ambiente e à saúde pública. A classificação dos resíduos se fez através dos ensaios de solubilização e lixiviação realizados em amostras de mistura asfáltica convencional e misturas compostas por pedra britada (90\%), asfalto $(6 \%)$ e borracha $(4 \%)$.

Foram utilizados dois tipos de borracha: borracha triturada fornecida pela BORCOL Indústria de Borracha Ltda e raspas (borracha da banda de rodagem) fornecidas por empresas de recauchutagem. 
Os ensaios foram realizados no Laboratório de Saneamento do Departamento de Hidráulica e Saneamento da Escola de Engenharia de São Carlos, USP, conforme procedimentos descritos na NBR 10005 (Lixiviação de Resíduos - ABNT, 1987b) e NBR 10006 (Solubilização de Resíduos - ABNT, 1987c).

Conforme a NBR 10004 da Associação Brasileira de Normas Técnicas (ABNT, 1987a), têm-se as seguintes classes de resíduos:

- Resíduo Classe I - perigosos: são os que apresentam riscos ao meio ambiente e exigem tratamento e disposição especiais, ou que apresentam riscos à saúde pública;

- Resíduo Classe II - não inertes: aqueles que não se enquadram nas classificações de resíduos classe I ou III, podendo apresentar propriedades tais como combustibilidade, biodegradabilidade ou solubilidade em água;

- Resíduo Classe III - inertes: são os resíduos que não se degradam ou não se decompõem quando dispostos no solo.

Para a realização desses ensaios foram extraídas do centro dos corpos-deprova, utilizando-se serra de diamante, amostras com aproximadamente $4 \mathrm{~cm}$ de diâmetro e $2 \mathrm{~cm}$ de altura. Para fins de comparação, também foram feitos ensaios utilizando somente amostras de borracha.

\subsection{3 - Dosagem Marshall}

\subsubsection{1 - Preparação dos Materiais e Moldagem dos Corpos-de-prova}

Depois de coletados e secos ao ar, os agregados foram separados mediante peneiramento manual nas frações correspondentes a cada uma das peneiras especificadas na Tabela 27, sendo cada fração armazenada individualmente 
em sacos plásticos devidamente etiquetados. Repetiu-se o mesmo procedimento para a borracha $G$ e F, que foram separadas nas frações especificadas.

Posteriormente, os agregados foram pesados e remisturados de acordo com a curva granulométrica selecionada e nas quantidades previstas para cada fim. $\mathrm{O}$ mesmo procedimento foi repetido para a borracha. Este procedimento foi adotado para as dosagens pelo método Marshall e na confecção dos corpos-deprova para os ensaios de estabilidade e fluência Marshall, resistência à tração, módulo de resiliência, ensaio Cântabro e para o ensaio de umidade induzida (AASHTO T-283).

Os corpos-de-prova foram moldados de acordo com os padrões estabelecidos pela NBR 12891/1993 da ABNT (1993). Os agregados, pesados e separados para a composição de pelo menos três corpos-de-prova, foram colocados em bandejas metálicas e levados à estufa na temperatura de $175^{\circ} \mathrm{C}$, por um período mínimo de 12 horas. Os asfaltos, armazenados em recipientes de alumínio com capacidade de aproximadamente 2 litros, foram aquecidos em estufa à temperatura de $160^{\circ} \mathrm{C}$, por um período mínimo de 4 horas. As temperaturas dos agregados pétreos, ligantes e misturas foram cuidadosamente controladas, utilizando-se um termômetro digital.

Os cilindros metálicos utilizados na moldagem dos corpos-de-prova também foram colocados na estufa em que estavam os recipientes com asfalto, para serem previamente aquecidos, evitando assim o esfriamento da mistura durante o processo de compactação.

Os agregados foram retirados da estufa e transferidos para uma misturadora de laboratório para que a borracha, na temperatura ambiente, fosse adicionada ao agregado previamente aquecido, durante aproximadamente 30 segundos. 
Em seguida, foi adicionado o ligante asfáltico, previamente pesado em uma balança eletrônica com sensibilidade de $0,1 \mathrm{~g}$, nas quantidades que seriam utilizadas no preparo das misturas (considerou-se um excedente para compensar o material que ficava retido nas paredes do recipiente). A mistura entre agregados, borracha e asfalto foi realizada manualmente, durante aproximadamente 2 minutos, até que o ligante tivesse envolvido todo o material granular (agregado pétreo e borracha).

Antes da compactação, parte das misturas foi moldada imediatamente e outra parte foi levada para uma estufa na temperatura de $150^{\circ} \mathrm{C}$, onde permaneciam durante duas ou quatro horas para simular o envelhecimento durante as fases de preparação, transporte e lançamento da mistura na pista.

A mistura era, então, colocada no cilindro, acomodada com uma espátula e compactada com a aplicação de 75 golpes em cada face do corpo-de-prova. Após a compactação, os corpos-de-prova eram deixados esfriar dentro dos cilindros metálicos. Após esta etapa, os corpos-de-prova eram extraídos dos cilindros e deixados ao ar livre durante 24 horas.

Após o esfriamento total dos corpos-de-prova, foram determinadas as massas ao ar e imersa em água e tiradas as medidas de diâmetro e altura para a obtenção dos elementos necessários ao cálculo das características físicas dos corpos-de-prova. A determinação da massa específica das misturas compactadas foi feita de acordo com o método AASHTO T-166 (AASHTO, 1993), utilizando amostras saturadas secas superficialmente, conforme apresentado na Figura 26. 


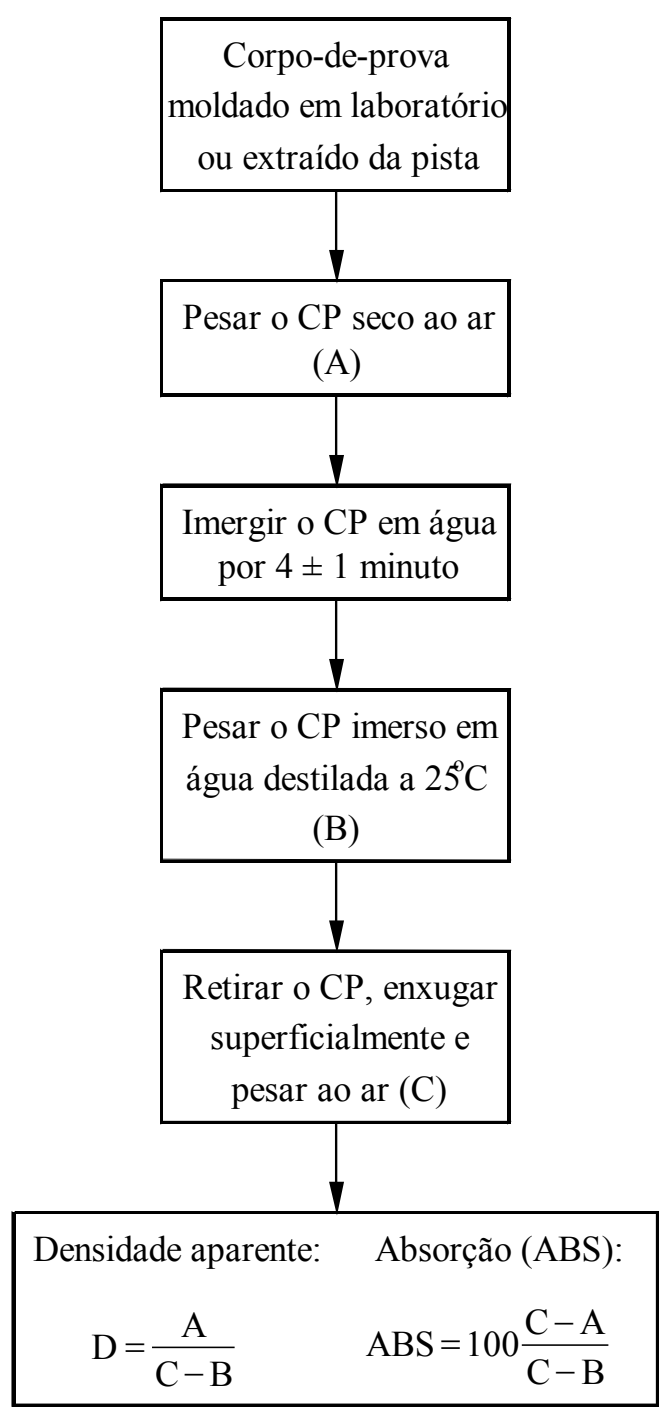

FIGURA 26 - Determinação da densidade aparente considerando amostras na condição de amostra saturada seca superficialmente (AASHTO T-166).

As misturas de controle $\mathrm{e}$ as preparadas com $2 \%$ de borracha nas granulometrias $\mathrm{G}$ e $\mathrm{F}$, destinadas à determinação do módulo de resiliência, resistência à tração por compressão diametral e perda de massa no ensaio Cântabro, foram moldadas com um teor de asfalto necessário para a obtenção de um volume de vazios em torno de 4\%. Para verificar a influência do teor de asfalto nas propriedades das misturas que contêm borracha, também foram moldados corpos-de-prova com a mesma quantidade de ligante da mistura de controle. 


\subsubsection{2 -Estabilidade e Fluência Marshall}

Os ensaios Marshall foram realizados de acordo com os procedimentos descritos no item "5.4 - Determinação da estabilidade e da fluência" da norma NBR 12891/1993. Após a desmoldagem, os corpos-de-prova foram imersos em banho de água a $60^{\circ} \mathrm{C}$, por um período entre 30 e 40 minutos, e a seguir foram submetidos ao ensaio de compressão diametral, para a determinação da estabilidade e fluência.

O equipamento existente no LTP/EPUSP consiste de uma prensa que se desloca verticalmente a uma velocidade constante de $5 \mathrm{~cm} / \mathrm{min}(0,8 \mathrm{~mm} / \mathrm{s})$. Nessa prensa estão acoplados uma célula de carga de 5 toneladas (carga máxima) e um extensômetro digital eletrônico (fowler). Os dispositivos de leitura estão conectados a um microcomputador que registra, através de um programa de aquisição de dados, as leituras da célula de carga e do fowler, que mede o deslocamento vertical ocorrido durante a realização do ensaio (Figura 27).

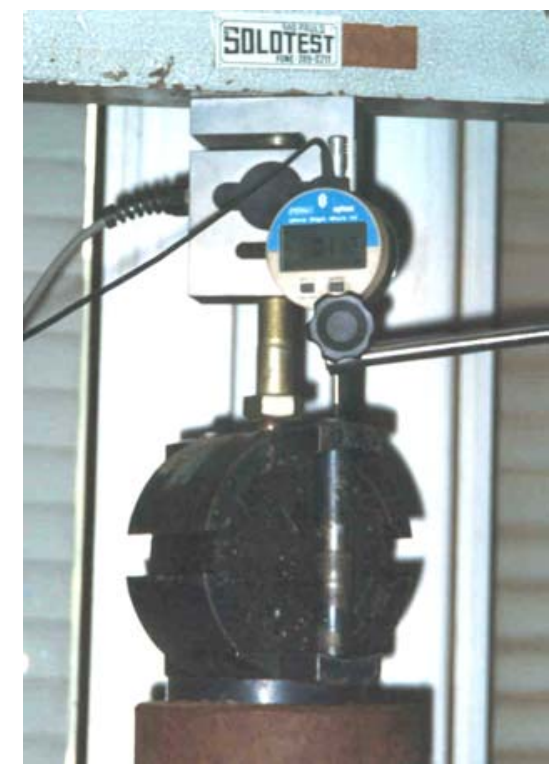

FIGURA 27 - Dispositivos de leitura para determinação da estabilidade e fluência. 
A aquisição automática dos dados proporciona a geração de dois gráficos: Carga x Tempo e Deslocamento x Tempo. A estabilidade é obtida através leitura da carga (expressa em $\mathrm{kg}$ ) no instante em que ocorre a ruptura do corpo-de-prova. Os valores de estabilidade são corrigidos em função da altura dos corpos-de-prova. A fluência corresponde ao deslocamento (expresso em $\mathrm{mm}$ ) ocorrido no ponto de ruptura.

Deve-se destacar que o ensaio Marshall, apesar de questionado porque as tensões que ocorrem durante a determinação da estabilidade e fluência são de difícil interpretação, por apresentar elevada dispersão de resultados e pela falta de correlação com o desempenho em campo, ainda é uma referência no Brasil, motivo pelo qual foi incluído neste trabalho. Complementarmente, foram realizados ensaios para determinação do módulo de resiliência (DNER, 1994a) e resistência à tração por compressão diametral (DNER, 1994b).

\subsection{4 - Determinação do Módulo de Resiliência}

O módulo de resiliência é um fator importante na definição do dimensionamento racional dos pavimentos, estando intimamente ligado ao projeto da mistura. É definido como a razão entre a tensão de tração e a correspondente deformação específica recuperável, quando as misturas asfálticas são submetidas a carregamentos cíclicos, de baixa duração. Trata-se de um ensaio que apresenta simplicidade de execução, facilidade de obtenção dos corpos-de-prova (cilindro Marshall) e boa representação do estado de tensões que ocorre no pavimento em serviço.

A Figura 28 apresenta uma vista geral do equipamento utilizado na determinação do módulo de resiliência de misturas betuminosas. 


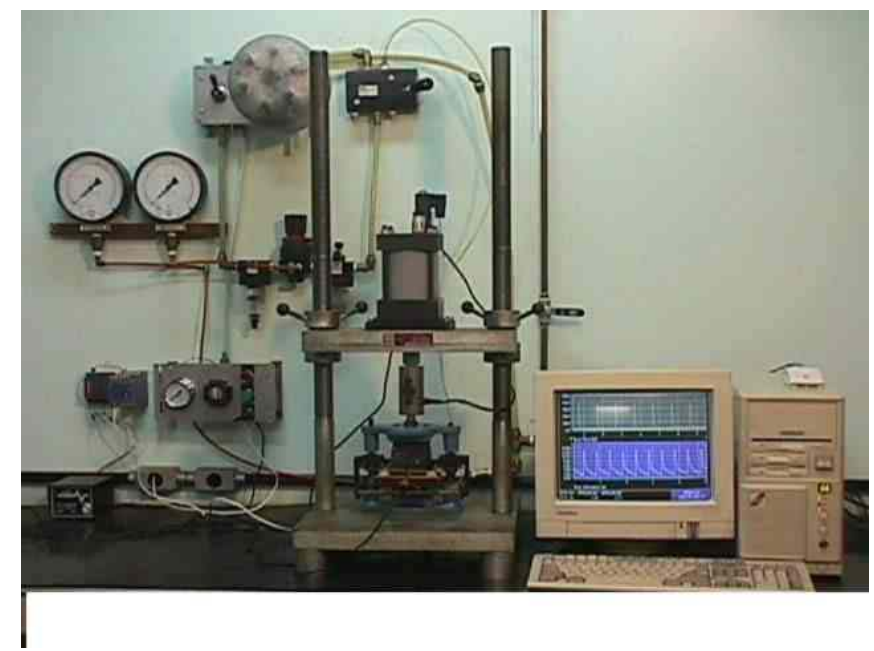

FIGURA 28 - Equipamento utilizado na determinação do módulo de resiliência do LTP/EPUSP.

O ensaio consiste em solicitar uma amostra cilíndrica dinamicamente por uma carga (F) de compressão distribuída ao longo de duas geratrizes opostas e medir a deformabilidade resiliente ou elástica $(\Delta)$ ao longo do diâmetro horizontal, perpendicular à carga $(\mathrm{F})$ aplicada repetidamente. Tratam-se de tensões bem abaixo da de ruptura estática do material, já que de pretende ficar no regime elástico. As deformações diametrais horizontais sofridas pela amostra são medidas através de um medidor eletromecânico LVDT (Linear Variable Differential Transformer) - Figura 29.

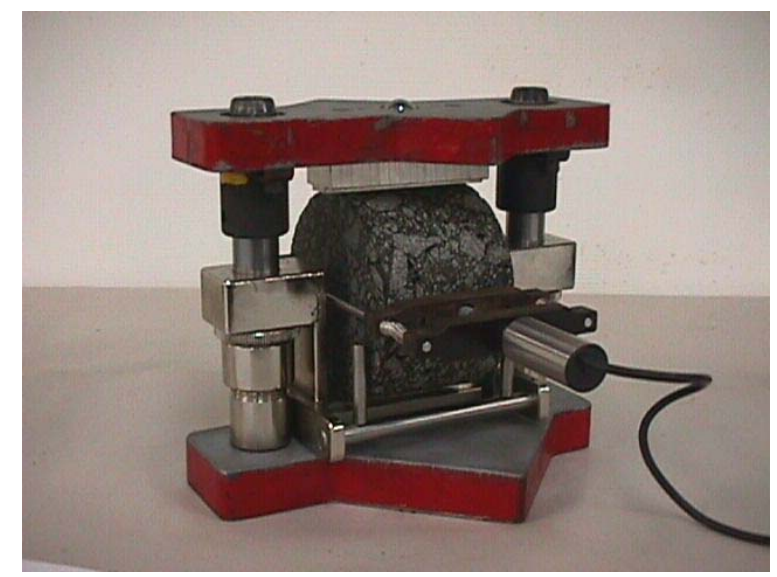

FIGURA 29 - Dispositivo LVDT utilizado para medir as deformações sofridas pelo corpo-de-prova. 
Os dispositivos eletromecânicos (célula de carga e LVDT) são conectados a um microcomputador que registra, através de um programa de aquisição de dados, os valores de carga e deslocamento. São aplicados 500 ciclos em cada corpo-de-prova. Cada ciclo tem a duração de 1 segundo, sendo $0,1 \mathrm{~s}$ de carregamento e $0,9 \mathrm{~s}$ de alívio. São registrados os 10 ciclos que antecedem, respectivamente, os ciclos de número 300, 400 e 500. Os valores de carga e deslocamento necessários ao cálculo do módulo de resiliência são o resultado da média dos valores obtidos nos ciclos registrados. Esse procedimento se repete para cada corpo-de-prova, que é girado em $90^{\circ}$ em relação à posição inicial de ensaio, permitindo a validação (ou não) do resultado.

O módulo de resiliência é calculado conforme a norma DNER-ME 133/94 (DNER, 1994a), pela expressão:

$$
\mathrm{MR}=\frac{\mathrm{F}}{100 \cdot \Delta \cdot \mathrm{H}}(0,9976 \mu+0,2692)
$$

onde: $\quad$ MR $=$ módulo de resiliência, $\mathrm{MPa}$;

$\mathrm{F}=$ carga vertical repetida aplicada diametralmente no corpo-deprova, $\mathrm{N}$;

$\Delta=$ deformação elástica ou resiliente correspondente à carga aplicada, cm;

$\mathrm{H}=$ altura do corpo-de-prova, $\mathrm{cm}$;

$\mu=$ coeficiente de Poisson (a norma recomenda adotar o valor de 0,30$)$.

Os ensaios foram realizados em sala climatizada, com temperatura média de $25^{\circ} \mathrm{C}$. Os valores de módulo de resiliência apresentados neste trabalho representam a média de 3 corpos-de-prova ensaiados. 


\subsection{5 -Determinação da Resistência à Tração}

O ensaio para determinação da resistência à tração por compressão diametral é padronizado pelo DNER-ME 138/94 (DNER, 1994b). A resistência à tração é associada ao comportamento estrutural adequado ou não das misturas quanto à vida de fadiga.

No ensaio, cada corpo-de-prova é apoiado ao longo de suas geratrizes por dois frisos de carga posicionados na parte inferior e superior da amostra (Figura 30). Através de uma prensa que impõe o deslocamento vertical a velocidade constante de $5 \mathrm{~cm} / \mathrm{min}(0,8 \mathrm{~mm} / \mathrm{s})$, aplica-se a carga progressivamente até atingir a ruptura do corpo-de-prova. O dispositivo de leitura é conectado a um microcomputador que registra, através de um programa de aquisição de dados, as leituras da célula de carga.

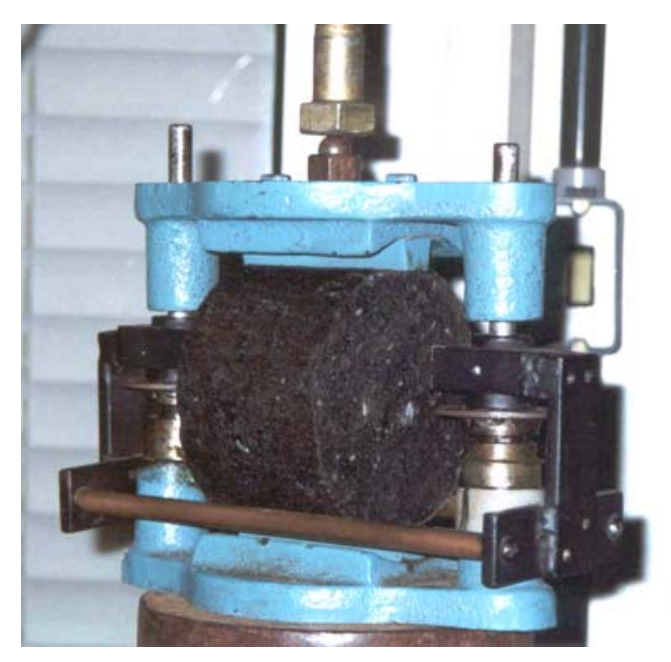

FIGURA 30 - Detalhe do equipamento utilizado na realização do ensaio de resistência à tração por compressão diametral.

A resistência à tração estática é calculada pela equação:

$$
\sigma_{\mathrm{R}}=\frac{2 \mathrm{~F}}{100 \pi \mathrm{DH}}
$$


onde: $\quad \sigma_{\mathrm{R}}=$ resistência à tração, $\mathrm{Mpa}$;

$\mathrm{F}=$ carga de ruptura, $\mathrm{N}$;

$\mathrm{D}=$ diâmetro do corpo-de-prova, $\mathrm{cm}$;

$\mathrm{H}=$ altura do corpo-de-prova, $\mathrm{cm}$.

Os ensaios foram realizados em sala climatizada, com temperatura média de $25^{\circ} \mathrm{C}$. Os valores de resistência à tração apresentados neste trabalho representam a média de 3 corpos-de-prova ensaiados.

\subsection{6 - Deformação Permanente em Simulador de Tráfego}

Para a avaliação da capacidade das misturas em resistir às deformações permanentes foi utilizado um equipamento simulador de tráfego em laboratório, idealizado pelo Laboratoire Central des Ponts et Chaussées LCPC. Os procedimentos do ensaio são descritos nas normas francesas NF P 98-253-1 (AFNOR, 1991a) e NF P 98-250-2 (AFNOR, 1991b).

Para a realização desse ensaio foram moldadas placas de $180 \mathrm{~mm}$ de largura por $500 \mathrm{~mm}$ de comprimento e $50 \mathrm{~mm}$ de altura. A quantidade de massa necessária para a confecção de cada placa variou entre 10 e $12 \mathrm{~kg}$, sendo este valor determinado através das densidades obtidas no ensaio Marshall.

As misturas foram usinadas numa misturadora industrial com capacidade para $20 \mathrm{~kg}$ de material, conforme Figura 31(a). A Figura 31(b) apresenta o momento em que era adicionada a borracha triturada ao agregado pétreo, durante a preparação de uma mistura. Anteriormente à compactação das placas, as misturas foram deixadas em estufa na temperatura de $150^{\circ} \mathrm{C}$ durante 2 horas. 


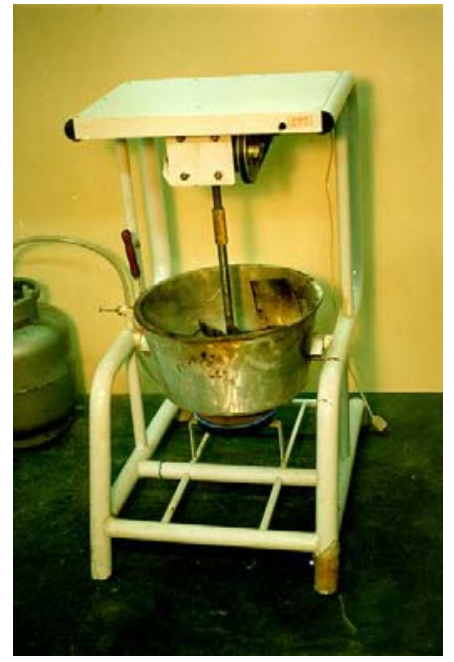

(a) Misturadora

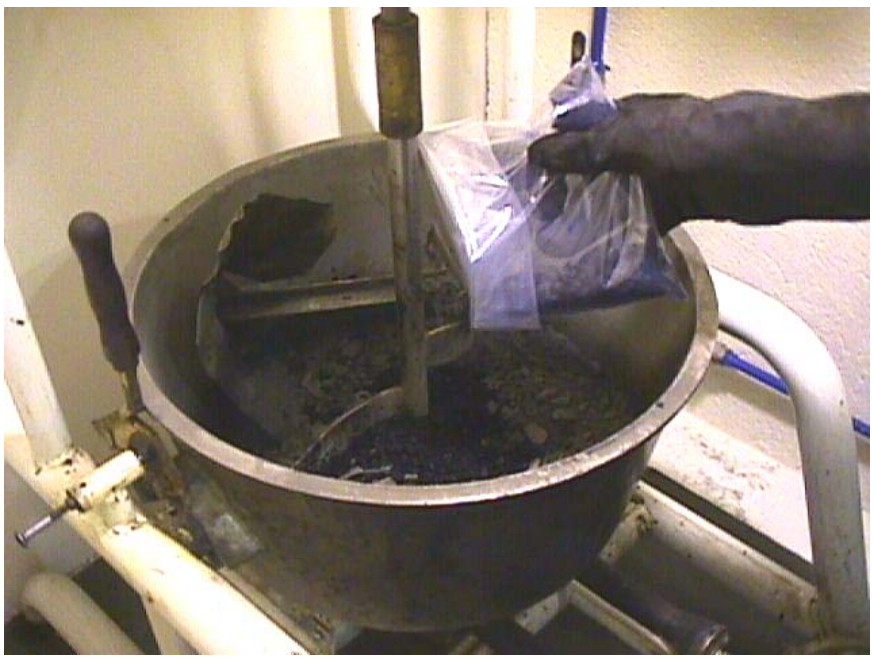

(b) Adição da borracha ao agregado pétreo

FIGURA 31 - Misturadora utilizada na usinagem das misturas asfálticas no LTP/EPUSP.

A Figura 32(a) apresenta a mesa compactadora tipo LCPC utilizada na moldagem das placas. $\mathrm{O}$ processo de compactação se desenvolve por amassamento, através de um roda dotada de um pneu de borracha, conforme mostrado na Figura 32(b). A pressão do pneu, a carga do eixo e a quantidade de passadas da roda são controladas. Para cada mistura foram moldadas duas placas.

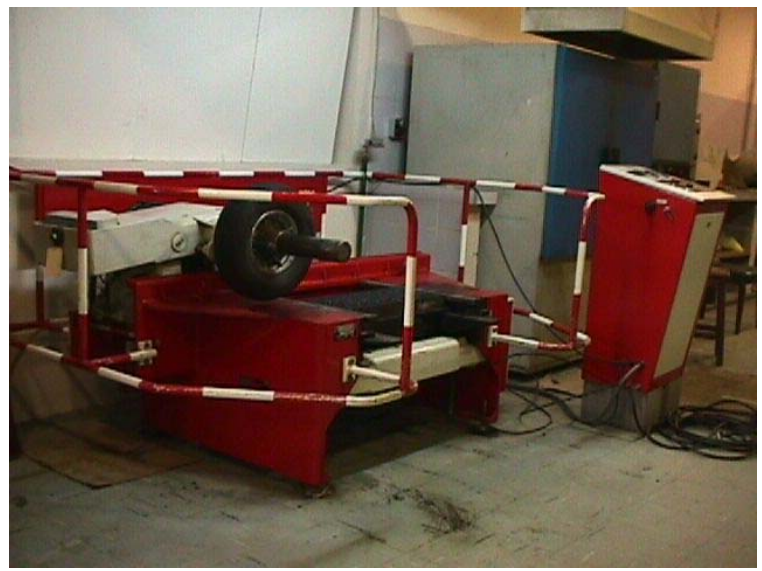

(a) Mesa compactadora tipo LCPC

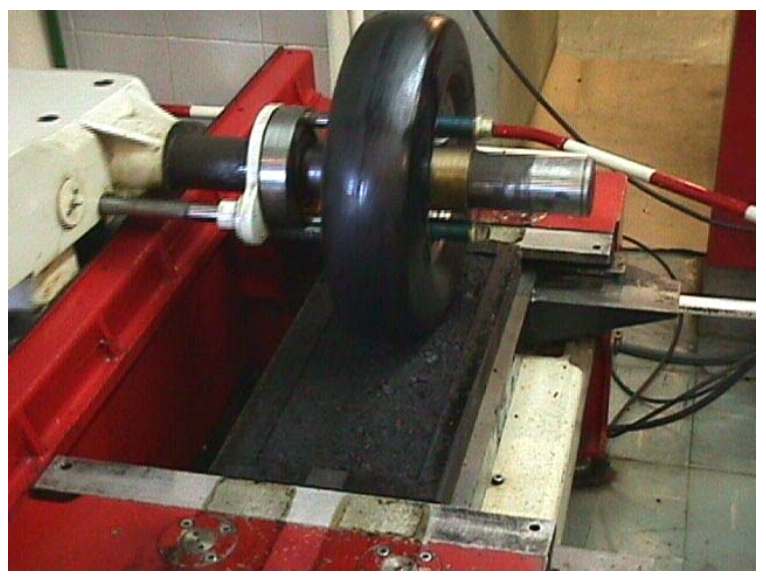

(b) Detalhe do processo de compactação

FIGURA 32 - Moldagem das placas para o ensaio de trilha de roda. 
No equipamento simulador de tráfego são colocadas duas placas de cada vez (Figura 33). O ensaio se realiza mediante a aplicação de carga através de uma roda dotada de pneus lisos. A pressão dos pneus e a carga dos eixos são controladas. A passagem das rodas sobre as placas se faz através de ciclos de ida e volta do pneu (freqüência de $1 \mathrm{~Hz}$ ). As medidas das deformações foram feitas em 15 pontos distintos da trilha de roda, sendo realizadas no decorrer do ensaio, após 100, 300, 1.000, 3.000, 10.000 e 30.000 ciclos. Os ensaios foram realizados em temperatura controlada de $60^{\circ} \mathrm{C}$.

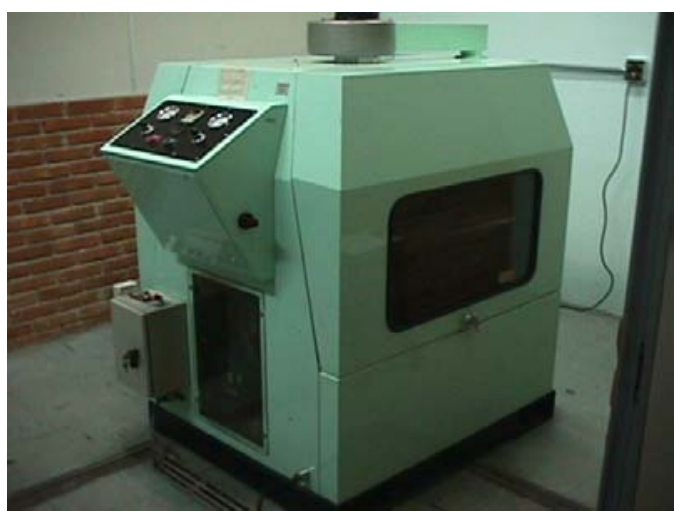

(a) Equipamento simulador de tráfego

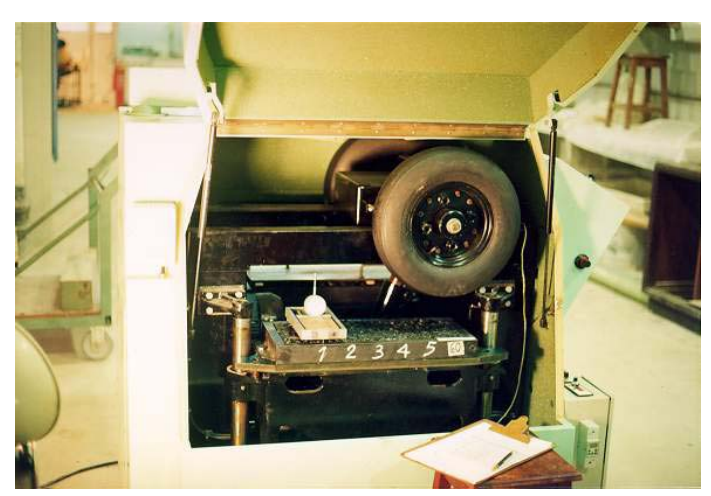

(b) Medidas de afundamento

FIGURA 33 - Equipamento simulador de tráfego em laboratório tipo LCPC, instalado no LTP/EPUSP.

Para cada conjunto de placas obtém-se uma equação de regressão do tipo $\mathrm{y}=\mathrm{a} . \mathrm{N}^{\mathrm{b}}$, onde " $\mathrm{y}$ " representa o valor do afundamento na trilha de roda, "N" é o número de ciclos e "a" e "b" são obtidos de análise de regressão. O coeficiente "b" representa a taxa de deformação com o número de ciclos. 


\subsection{7 -Ensaio Cântabro}

O ensaio espanhol Cântabro permite avaliar, indiretamente, a coesão e resistência à desintegração das misturas betuminosas de granulometria descontínua ante os efeitos abrasivos originados pelo tráfego. Misturas abertas apresentam elevado teor de vazios, o que pode permitir a indesejável entrada de água e ar no pavimento.

Neste trabalho, misturas asfálticas densas foram submetidas ao ensaio Cântabro buscando verificar se a adição de borracha proporciona algum benefício às misturas asfálticas, em termos de resistência à desagregação. A avaliação é feita através da análise comparativa entre a mistura de controle e as misturas contendo borracha. Estudo conduzido por OLIVER (2000) sugere que o ensaio Cântabro pode ser viável para esse tipo de análise.

Para cada teor de ligante são necessários quatro corpos-de-prova a serem ensaiados um de cada vez. O ensaio é realizado na máquina de abrasão Los Angeles, sem as esferas de aço. Depois de pesado, cada corpo-de-prova é colocado no cilindro Los Angeles e submetido a 300 revoluções. Ao final do ensaio, o corpo-de-prova é pesado novamente.

A perda por desgaste de cada corpo-de-prova é calculada pela expressão:

$$
\mathrm{P}=\frac{\mathrm{P}_{1}-\mathrm{P}_{2}}{\mathrm{P}_{1}} \times 100
$$

onde:

$\mathrm{P}=$ valor da perda por desgaste (\%)

$\mathrm{P}_{1}=$ massa inicial $(\mathrm{g})$

$\mathrm{P}_{2}=$ massa final $(\mathrm{g})$ 
O valor do desgaste para cada teor de ligante é obtido pela média dos resultados obtidos para quatro corpos-de-prova. O ensaio é realizado na temperatura de $25^{\circ} \mathrm{C}$.

\subsection{8 - Resistência de Misturas Betuminosas Compactadas a Danos por Umidade Induzida}

A prática brasileira de avaliação da adesividade agregado-ligante tem se limitado aos ensaios visuais de verificação da ocorrência de desprendimento da película de ligante em agregados graúdos (após imersão em banho de água destilada a $40^{\circ} \mathrm{C}$ por 72 horas) e agregados miúdos (quando a mistura é submetida à ação de água destilada fervente e a soluções de carbonato de sódio ferventes). Esses métodos não apresentam correlação com o que acontece no campo, podendo apresentar resultados enganosos.

No método de dosagem SUPERPAVE ${ }^{\circledR}$, a avaliação da sensibilidade à umidade da mistura asfáltica é feita através do método de ensaio AASHTO T283 (Resistance of Compacted Bituminous Mixture to Moisture Induced Damage). Os resultados permitem a estimativa do descolamento da película de ligante do agregado nas misturas betuminosas e a avaliação de aditivos líquidos, como os melhoradores de adesividade que são usados nos ligantes (dope), ou sólidos em pó, tal como a cal hidratada, que são adicionados ao agregado.

São produzidos dois subgrupos com três corpos-de-prova cada, que são compactados para atingirem um teor de vazios entre 6 e $8 \%$ (o volume de vazios deve ser obtido ajustando-se o número de golpes durante a compactação). Um subgrupo é condicionado pela saturação a vácuo (grau de saturação entre 55 e $80 \%$ ). Em seguida, aplicam-se ciclos de congelamento 
(etapa opcional) e imersão em banhos de água. Todos os corpos-de-prova são avaliados em termos de resistência à tração indireta. Misturas não suscetíveis à umidade apresentam a proporção entre resistência à tração de amostras condicionadas e não condicionadas maior que $70 \%$. A Figura 34 apresenta as etapas para a realização do ensaio de acordo com o método AASHTO T-283 (AASHTO, 1989).

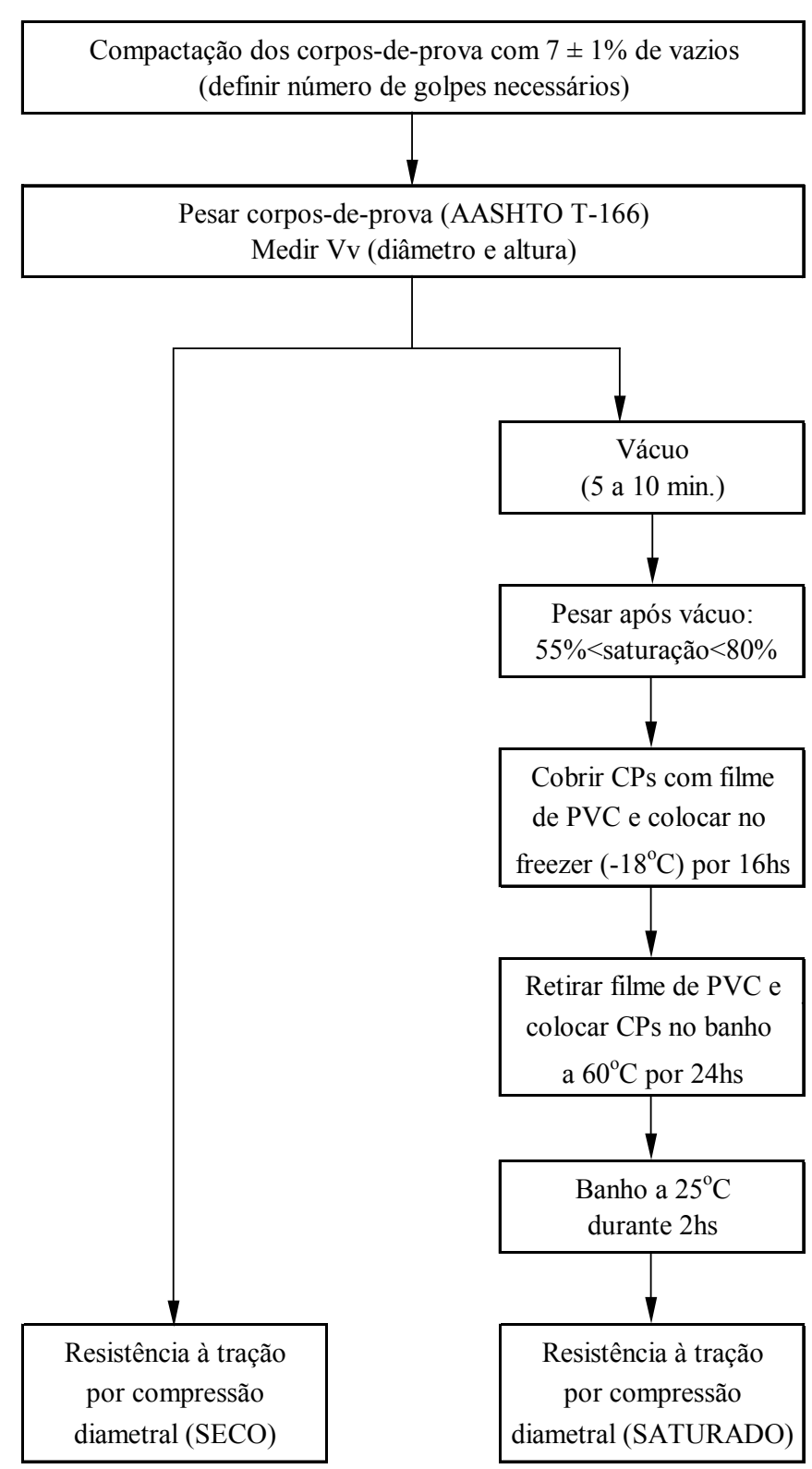

FIGURA 34 - Ensaio para a determinação da resistência de misturas betuminosas compactadas a danos por umidade induzida (AASHTO T-283). 
A Figura 35 apresenta os equipamentos utilizados na saturação a vácuo dos corpos-de-prova no ensaio de umidade induzida.

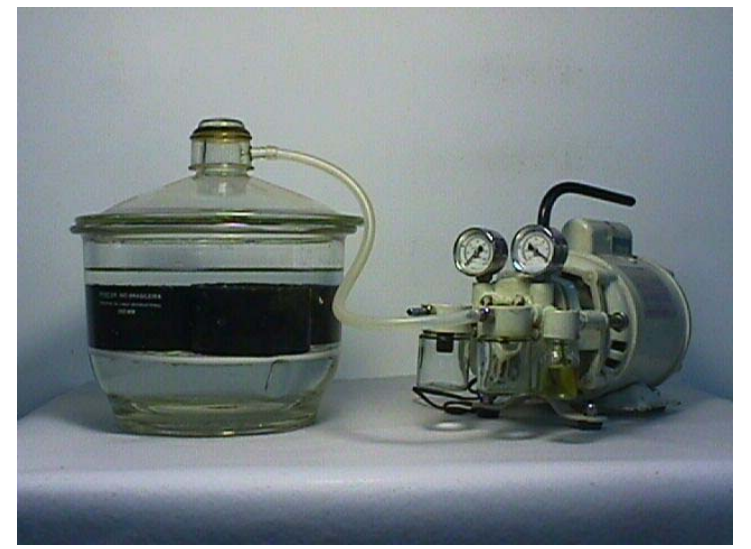

FIGURA 35 - Equipamentos utilizados na saturação a vácuo dos corpos-deprova: dessecador e bomba de vácuo. 


\section{6 - APRESENTAÇÃo e ANÁlise dOS RESUltados}

\section{1 - CONSIDERAÇÕES INICIAIS}

Anteriormente à definição do planejamento fatorial, foram realizados alguns ensaios exploratórios com o objetivo de dirimir algumas das inúmeras dúvidas surgidas ao se trabalhar com um material não convencional. Os ensaios exploratórios visaram propiciar uma idéia inicial do comportamento desse novo material permitindo que os próximos ensaios utilizassem misturas com alguma garantia de sucesso.

Este capítulo apresenta os resultados de todos os ensaios laboratoriais realizados neste estudo: solubilização e lixiviação de resíduos, estabilidade e fluência Marshall, módulo de resiliência, resistência à tração por compressão diametral, deformação permanente em trilha de roda, umidade induzida e perda de massa no ensaio Cântabro.

Procurou-se, particularmente, analisar como os fatores granulometria da borracha, teor de borracha, teor de ligante asfáltico e envelhecimento de curto prazo (tempo de digestão) influenciam as propriedades de uma mistura asfáltica densa onde parte dos agregados é substituída por borracha de pneumáticos triturada. 
Os ensaios de solubilização e lixiviação foram realizados com o intuito de enquadrar as diferentes amostras (borracha, mistura asfáltica convencional e mistura asfáltica modificada) em cada uma das classes de resíduos e verificar se a incorporação da borracha nas misturas asfálticas não irá proporcionar danos ao meio ambiente.

Foram moldados um total de 340 corpos-de-prova Marshall e 14 placas para o ensaio de deformação permanente em trilha de roda, o que consumiu aproximadamente $550 \mathrm{~kg}$ de agregado pétreo, $16 \mathrm{~kg}$ de borracha triturada e 39 litros de ligante asfáltico.

\section{2 - ENSAIOS EXPLORATÓRIOS}

Para a avaliação das misturas preparadas durante a realização dos ensaios exploratórios, foram considerados os ensaios tradicionais, normalmente realizados no Laboratório de Estradas do Departamento de Transportes da Escola de Engenharia de São Carlos da USP: método Marshall, para determinação da estabilidade e fluência, e o ensaio de fluência por compressão uniaxial estática (static creep test), para avaliação de misturas em termos de resistência à deformação permanente.

Deve-se destacar as limitações do ensaio de creep estático para caracterizar materiais não convencionais. Trata-se de um método de ensaio empírico pois não simula, em laboratório, as verdadeiras condições de tensão que ocorrem com os materiais no campo.

Para a realização do ensaio de creep estático utilizou-se uma prensa de adensamento de solos adaptada. O ensaio consiste basicamente em submeter 
um corpo-de-prova a uma carga estática de valor constante, durante um determinado período de tempo, sob condições de temperatura previamente fixada e mantida constante durante o ensaio. Neste trabalho, considerou-se um carregamento de 4,0 kgf $/ \mathrm{cm}^{2}$, com tempo de carregamento de 60 minutos e tempo de recuperação de 60 minutos ( 15 minutos para a mistura de controle), para que fossem traçadas as curvas de fluência e recuperação. Os ensaios foram realizados na temperatura de $40^{\circ} \mathrm{C}$.

Inicialmente, trabalhou-se com as partículas maiores de borracha (granulometria G) que, devido ao menor tempo de processamento e, conseqüentemente, menor custo energético, apresentam menor custo de aquisição quando comparadas ao pó de pneu. Para facilitar a análise dos resultados, buscou-se trabalhar com 3 frações de borracha denominadas G', C' e F'. A borracha "grossa" (G') é a fração passando na peneira 3/8" (9,5 mm) e retida na peneira \# 4 (7,75 mm); a "fina" (F') é a fração de borracha passada na peneira \# $16(1,18 \mathrm{~mm})$ e retida na peneira \# $30(0,60 \mathrm{~mm})$ e a "contínua" (C') acompanha a faixa do DNER, no trecho entre as peneiras 3/8" e \# 30.

No início dos experimentos buscou-se determinar o teor máximo de borracha passível de ser incorporado no centro da faixa " $C$ " do DNER. Preparou-se material para moldar corpos-de-prova utilizando borracha na granulometria C' (3/8" - \#30) e teor de $6 \%$, substituindo o agregado pétreo por borracha em equivalência de volume. Após os primeiros 75 golpes do soquete compactador, verificou-se que as misturas não sofriam compactação. Ao se inverter o cilindro, a massa no interior do molde vinha a cair. Procurou-se então trabalhar com um teor máximo de $4 \%$ para a borracha.

Outro problema na fase inicial foi determinar a melhor maneira de substituir o agregado pétreo por borracha. A bibliografia internacional cita várias situações em relação a esse aspecto: o sistema PlusRide ${ }^{\circledR}$ utiliza agregados que 
apresentam descontinuidade na sua curva de distribuição granulométrica e a borracha é adicionada nos teores especificados; no sistema genérico, utiliza-se curvas granulométricas densas onde o agregado é substituído por baixos teores de borracha; em alguns casos, simplesmente é adicionada borracha em concentrações muito pequenas.

Procurou-se analisar as duas formas de substituição dos agregados pétreos por borracha: adicionar a borracha retirando a massa equivalente de agregado ou adicionar a borracha retirando o volume equivalente de agregado. Para facilitar a análise dos resultados, fixou-se o teor de borracha em $4 \%$ e buscouse trabalhar com as 3 frações de borracha: G' (3/8" - \#4), C' (3/8" - \#30) e F' (\#16 - \#30). Todas as misturas destinadas aos ensaios para determinação da estabilidade e fluência Marshall e compressão uniaxial estática foram moldadas com um teor de asfalto necessário para a obtenção de um teor de vazios em torno de $4 \%$, por ser este valor usualmente recomendado na literatura técnica.

Verificou-se o aumento no valor da estabilidade Marshall para todas as misturas preparadas com a substituição do agregado em "volume" quando comparadas com as misturas com substituição em "peso". Para confirmar o melhor comportamento das misturas onde a substituição do agregado é feita por equivalência de volume, foram realizados os ensaios de fluência por compressão uniaxial estática. Todas as misturas que tiveram substituídos os agregados por borracha em equivalência de volume apresentaram valores de deformação axial inferiores aos valores obtidos nas misturas que utilizaram substituição em peso.

Em seguida, foram analisadas misturas preparadas com $2 \%$ de borracha (teor recomendado na literatura). Pretendeu-se assim verificar a influência do tamanho e da graduação da borracha nas propriedades da mistura. As misturas 
preparadas com $4 \%$ de borracha apresentaram as maiores taxas de deformação (curvas mais inclinadas). Baseado nos critérios de ruptura da literatura corrente (LITTLE et al., 1993) e analisando os resultados dos ensaios, verificou-se que os corpos-de-prova preparados com $4 \%$ de borracha apresentaram deformação superior ao limite máximo estabelecido após 60 minutos de carregamento. Deste modo, para as etapas seguintes foi estabelecido um teor máximo de $2 \%$ para a borracha.

Verificou-se também que a substituição de uma única fração (G' ou F') de agregado pétreo por borracha não permitiu que fosse identificado o real efeito do diâmetro das partículas sobre o desempenho das misturas. Deste modo, constatou-se a necessidade de também investigar a incorporação de partículas menores de borracha, distribuídas continuamente na curva granulométrica dos agregados pétreos (a exemplo da granulometria C').

A última etapa dos ensaios exploratórios envolveu a investigação dos fatores tempo de digestão e teor de ligante, considerando as misturas preparadas com $2 \%$ de borracha nas granulometrias G e F. As misturas foram submetidas aos ensaios para determinação de módulo de resiliência e resistência à tração (investigação do tempo de digestão) e deformação permanente nas trilhas de roda (investigação do teor de ligante). Os resultados obtidos encontram-se nos itens 6.5 e 6.6 deste capítulo.

Aplicou-se a Análise de Variância como metodologia estatística para verificar a existência de diferenças significativas entre as misturas estudadas, nos diversos ensaios realizados. Essa análise testa a hipótese de igualdade das médias $\left(\mathrm{H}_{\mathrm{o}}\right)$, através da estimativa de variância entre tratamentos $\left(\mathrm{S}_{\mathrm{E}}^{2}\right)$ e da estimativa de variância dentro de tratamentos $\left(\mathrm{S}_{\mathrm{R}}^{2}\right)$. A razão entre essas duas variâncias $(F)$ é comparada com um valor de referência $\left(F_{\alpha}-\right.$ distribuição $F$ de 
Snedecor), ao qual está associado um nível de significância $(\alpha)$ e os graus de liberdade da amostra. Assim, não se rejeita a hipótese $H_{o}$ se $F \leq F_{\alpha}$ e rejeita-se essa hipótese se $\mathrm{F}>\mathrm{F}_{\alpha}$.

Quando a análise de variância leva à conclusão que os tratamentos não são iguais (hipótese $\mathrm{H}_{\mathrm{o}}$ rejeitada), admite-se que pelo menos uma das médias é diferente das demais. Segundo GIBRA (1973), no caso de comparações múltiplas entre amostras de tamanhos iguais, o método proposto por Tukey parece ser o procedimento mais eficiente para determinar quais médias devem ser consideradas diferentes de quais outras. O método de Tukey utiliza valores críticos da amplitude studentizada (q) e recomenda considerar distintas as médias cujas diferenças superem o valor obtido na equação

$$
\mathrm{q}_{\mathrm{k}, \mathrm{u}, \alpha} \sqrt{\frac{\mathrm{S}_{\mathrm{R}}^{2}}{\mathrm{n}}},
$$

onde $\underline{\mathrm{n}}$ é o número de elementos em cada tratamento, o valor de $\mathrm{q}$ tabelado em função do número de tratamentos $(\mathrm{k})$, do nível de significância $(\alpha)$ e dos graus de liberdade da amostra.

\section{3 - SolubiLIZAÇÃo E LiXIVIAÇão}

O ensaio de lixiviação procura reproduzir, em laboratório, os fenômenos de arraste e diluição que ocorrem pela passagem de água através do material. $\mathrm{O}$ ensaio de solubilização procura reproduzir as condições naturais de um resíduo disposto no solo e sujeito ao contato de águas pluviais e/ou subterrâneas. 
Os ensaios de solubilização e lixiviação foram realizados em amostras de borracha, de mistura asfáltica convencional (94\% de agregado e 6\% de ligante) e mistura asfáltica com um elevado teor de borracha $(90 \%$ de agregado, $6 \%$ de ligante e $4 \%$ de borracha). Procurou-se enquadrar as amostras em cada uma das classes de resíduos, segundo a NBR 10004 (Resíduos Sólidos - Classificação - ABNT, 1987a): resíduos classe I (perigosos), resíduos classe II (não inertes) e resíduos classe III (inertes).

As Tabelas 28 e 29 apresentam os resultados dos ensaios de lixiviação e solubilização das amostras estudadas: somente borracha (amostras 01 e 02), mistura asfáltica com borracha incorporada (amostras 03 e 04) e mistura asfáltica convencional (amostra 05).

TABELA 28 - Resultados do ensaio de lixiviação.

\begin{tabular}{l|c|c|c|c|c|c}
\hline \multirow{2}{*}{ Parâmetros } & \multirow{2}{*}{$\begin{array}{c}\text { L.M. } \\
(\mathbf{m g} / \mathbf{l})\end{array}$} & \multicolumn{6}{|c}{ Amostras } \\
\cline { 3 - 7 } & - & 7,30 & 6,34 & 7,65 & 7,22 & 7,28 \\
\hline pH Inicial & - & 4,95 & 4,90 & 5,06 & 5,10 & 5,02 \\
\hline pH Final & - & 10,5 & 4,0 & 5,0 & 0,5 & 2,0 \\
\hline $\begin{array}{l}\text { Vol. de ácido acético 0,5N } \\
\text { adicionado (ml) }\end{array}$ & - & 25,00 & 15,00 & $<0,002$ & $<0,002$ & $<0,002$ \\
\hline Zinco (mg/l) & 5,0 & $<0,02$ & $<0,02$ & $<0,02$ & $<0,02$ & $<0,02$ \\
\hline Chumbo (mg/l) & 0,5 & $<0,0006$ & $<0,0006$ & $<0,0006$ & $<0,0006$ & $<0,0006$ \\
\hline Cádmio (mg/l) & - & 0,62 & $<0,005$ & $<0,005$ & $<0,005$ & $<0,005$ \\
\hline Ferro (mg/l) & - & 0,18 & 0,03 & $<0,003$ & $<0,003$ & $<0,003$ \\
\hline Manganês (mg/l) & - & $<0,003$ & $<0,003$ & $<0,003$ & $<0,003$ & $<0,003$ \\
\hline Cobre (mg/l) & 5,0 & 0,04 & 0,04 & $<0,005$ & $<0,005$ & $<0,005$ \\
\hline Cromo Total (mg/l) & - & & $\mathbf{0 3}$ & $\mathbf{0 4}$ & $\mathbf{0 1}$ \\
\hline
\end{tabular}

L.M. - Limite Máximo estabelecido pela NBR 10004 da ABNT

${ }^{01}$ Raspas de borracha (banda de rodagem) fornecida por empresas de recauchutagem;

${ }^{02}$ Borracha triturada fornecida pela BORCOL Indústria de Borracha Ltda.;

${ }^{03}$ Mistura asfáltica preparada com raspas de recauchutagem;

${ }^{04}$ Mistura asfáltica preparada com borracha triturada;

${ }^{05}$ Mistura asfáltica convencional. 
TABELA 29 - Resultados do ensaio de solubilização.

\begin{tabular}{l|c|c|c|c|c|c}
\hline \multirow{2}{*}{ Parâmetros } & \multirow{2}{*}{$\begin{array}{c}\text { L.M. } \\
\text { (mg/l) }\end{array}$} & \multicolumn{6}{|c}{ Amostras } \\
\cline { 3 - 7 } & - & 7,95 & 7,90 & 7,72 & 7,30 & 7,35 \\
\hline pH Inicial & - & 7,42 & 7,30 & 7,60 & 7,20 & 7,30 \\
\hline pH Final & 5,0 & 5,00 & 7,00 & $<0,002$ & $<0,002$ & $<0,002$ \\
\hline Zinco (mg/l) & 0,05 & $<0,02$ & $<0,02$ & $<0,02$ & $<0,02$ & $<0,02$ \\
\hline Chumbo (mg/l) & 0,005 & $<0,0006$ & $<0,0006$ & $<0,0006$ & $<0,0006$ & $<0,0006$ \\
\hline Cádmio (mg/l) & 0,3 & $<0,005$ & $<0,005$ & $<0,005$ & $<0,005$ & $<0,005$ \\
\hline Ferro (mg/l) & 0,1 & 0,14 & 0,08 & $<0,003$ & $<0,003$ & $<0,003$ \\
\hline Manganês (mg/l) & 1,0 & $<0,003$ & $<0,003$ & $<0,003$ & $<0,003$ & $<0,003$ \\
\hline Cobre (mg/l) & 0,05 & 0,03 & 0,02 & $<0,005$ & $<0,005$ & $<0,005$ \\
\hline Cromo Total (mg/l) & & & 0,03 & $\mathbf{0 1}$ \\
\hline
\end{tabular}

L.M. - Limite Máximo estabelecido pela NBR 10004 da ABNT

${ }^{01}$ Raspas de borracha (banda de rodagem) fornecida por empresas de recauchutagem;

${ }^{02}$ Borracha triturada fornecida pela BORCOL Indústria de Borracha Ltda.;

${ }^{03}$ Mistura asfáltica preparada com raspas de recauchutagem;

${ }^{04}$ Mistura asfáltica preparada com borracha triturada;

${ }^{05}$ Mistura asfáltica convencional.

Os resultados dos ensaios de solubilização (NBR 10006) realizados nas amostras de borracha triturada e raspas de recauchutagem apresentaram concentrações de zinco e manganês superiores aos limites máximos estabelecidos na NBR 10004 (Resíduos Sólidos - Classificação). A análise dos valores das amostras 01 e 02 classifica este tipo de resíduo como sendo Classe II (não inerte). 
Houve redução na concentração de todos os parâmetros utilizados para a caracterização e classificação das amostras quando são comparadas as amostras de misturas asfálticas $(03,04$ e 05) com as amostras de borracha (01 e 02). Os resultados mostram que se pode incorporar borracha nas misturas asfálticas sem causar nenhum dano ao meio ambiente, satisfazendo as exigências da CETESB. E, mais ainda, que a utilização de borracha de pneus usados em pavimentação é muito melhor, ambientalmente, que a disposição em aterros sanitários.

\section{4 - DOSAGEM MARSHALL}

\subsection{1 - Efeito do Envelhecimento nas Propriedades Volumétricas}

Nas misturas preparadas com borracha, ocorre um processo chamado de "digestão" da borracha, ou seja, a interação asfalto-borracha durante o tempo de preparação e transporte da mistura. Buscando analisar o efeito do envelhecimento na mistura de controle e do tempo de digestão nas misturas preparadas com borracha, fez-se a simulação do envelhecimento em estufa, a $150^{\circ} \mathrm{C}$, por períodos de 2 e 4 horas antes da compactação.

A Tabela 30 apresenta os resultados de massa específica aparente $\left(D_{a p}\right)$, relação betume/vazios (RBV) e volume de vazios $\left(V_{v}\right)$ para diferentes teores de asfalto e períodos de envelhecimento. Os valores representam a média de três corpos-de-prova. Foram analisadas as misturas de controle e as misturas preparadas com $2 \%$ de borracha nas granulometrias $\mathrm{G}$ e F. 
TABELA 30 - Efeito do tempo de envelhecimento nas propriedades volumétricas.

\begin{tabular}{|c|c|c|c|c|c|}
\hline Mistura & $\begin{array}{c}\text { Estufa a } \\
150^{\circ} \mathrm{C}(\mathrm{h})\end{array}$ & Ligante (\%) & $\mathbf{D}_{\text {ap }}$ & RBV (\%) & $V_{v}(\%)$ \\
\hline \multirow{11}{*}{ Controle } & \multirow{3}{*}{0} & 5,7 & 2,447 & 71 & 5,6 \\
\hline & & 6,2 & 2,469 & 79 & 3,9 \\
\hline & & 6,7 & 2,473 & 84 & 3,0 \\
\hline & \multirow{5}{*}{2} & 5,0 & 2,425 & 61 & 7,5 \\
\hline & & 5,5 & 2,436 & 67 & 6,4 \\
\hline & & 6,0 & 2,461 & 76 & 4,6 \\
\hline & & 6,5 & 2,474 & 83 & 3,3 \\
\hline & & 7,0 & 2,481 & 88 & 2,3 \\
\hline & \multirow{3}{*}{4} & 5,7 & 2,435 & 69 & 6,1 \\
\hline & & 6,2 & 2,462 & 78 & 4,2 \\
\hline & & 6,7 & 2,471 & 84 & 3,1 \\
\hline \multirow{9}{*}{$2 \mathrm{G}$} & \multirow{3}{*}{0} & 6,4 & 2,356 & 72 & 5,7 \\
\hline & & 7,0 & 2,378 & 81 & 3,7 \\
\hline & & 7,5 & 2,389 & 86 & 2,8 \\
\hline & \multirow{3}{*}{2} & 6,4 & 2,344 & 69 & 6,1 \\
\hline & & 7,0 & 2,359 & 80 & 4,7 \\
\hline & & 7,5 & 2,370 & 83 & 3,5 \\
\hline & \multirow{3}{*}{4} & 6,4 & 2,316 & 66 & 7,3 \\
\hline & & 7,0 & 2,346 & 75 & 5,2 \\
\hline & & 7,5 & 2,358 & 81 & 4,0 \\
\hline \multirow{11}{*}{$2 \mathrm{~F}$} & \multirow{4}{*}{0} & 6,4 & 2,333 & 68 & 6,8 \\
\hline & & 7,0 & 2,353 & 76 & 5,0 \\
\hline & & 7,5 & 2,359 & 81 & 4,1 \\
\hline & & 8,0 & 2,369 & 86 & 2,9 \\
\hline & \multirow{4}{*}{2} & 6,4 & 2,325 & 67 & 7,1 \\
\hline & & 7,0 & 2,346 & 75 & 5,3 \\
\hline & & 7,5 & 2,348 & 79 & 4,5 \\
\hline & & 8,0 & 2,351 & 83 & 3,7 \\
\hline & \multirow{3}{*}{4} & 7,0 & 2,344 & 75 & 5,4 \\
\hline & & 7,5 & 2,345 & 79 & 4,7 \\
\hline & & 8,0 & 2,352 & 84 & 3,7 \\
\hline
\end{tabular}


A Figura 36 ilustra a relação entre teor de ligante e volume de vazios para as misturas com borracha (fina, $2 \mathrm{~F}$, e grossa, $2 \mathrm{G}$ ), ambas com $2 \%$ de borracha. A mistura de controle (Figura 37) não apresentou variação significativa do volume de vazios com o tempo de envelhecimento.

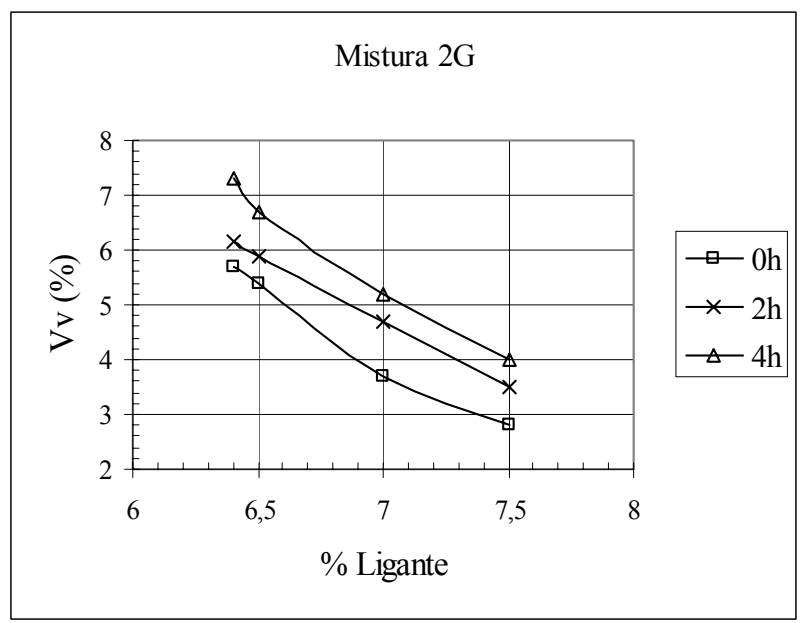

(a) Mistura com 2\% de borracha na granulometria $\mathrm{G}$

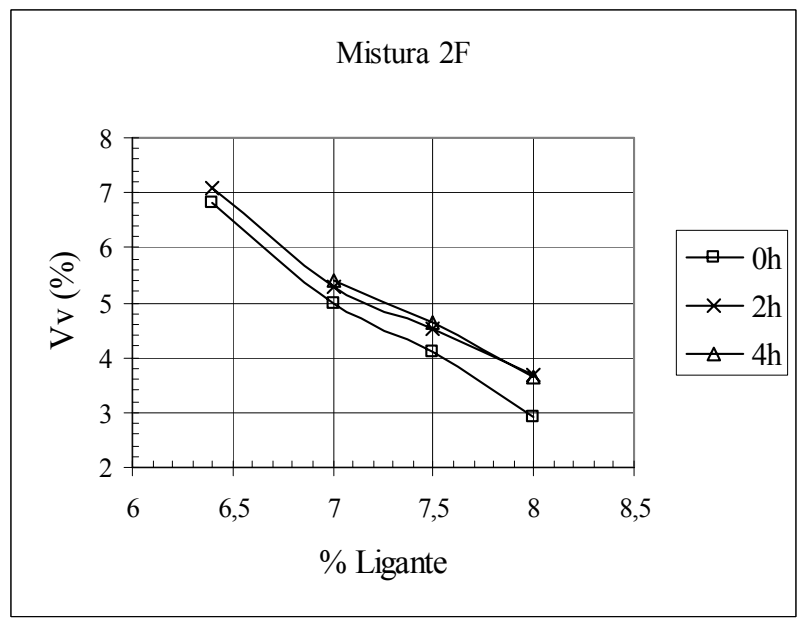

(b) Mistura com $2 \%$ de borracha na granulometria $\mathrm{F}$

FIGURA 36 - Efeito do envelhecimento (tempo de digestão) para as misturas com borracha. 


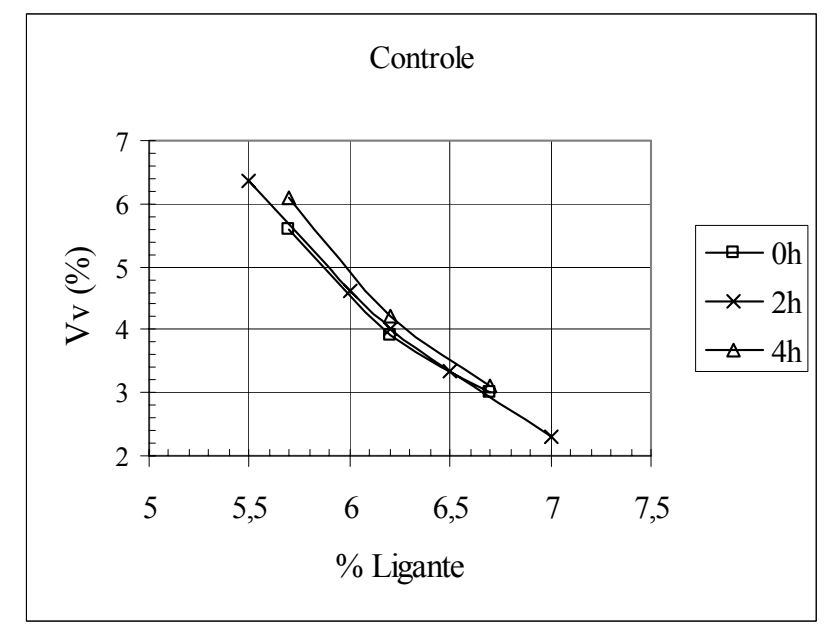

FIGURA 37 - Efeito do envelhecimento para a mistura de controle.

Observa-se o efeito do tempo de digestão nas misturas que contêm borracha: as misturas envelhecidas requerem maiores teores de ligante para a obtenção de um volume de vazios de 4\%. Uma parcela do ligante requerido pode estar sendo absorvida pela borracha, que apresenta elevada porosidade. A borracha triturada deve ser considerada como um agregado, entretanto, a parcela de borracha mais fina, que passa na peneira de abertura 0,84 mm (\# 20), reage parcialmente com o ligante. Essa ocorrência ficou evidente quando, após a mistura, verificou-se "aumento de volume", principalmente na mistura 2F.

Para a mistura $2 \mathrm{G}$ ocorreu reação, pois também apresenta partículas que passam na peneira de $0,84 \mathrm{~mm}$, só que de forma menos eficiente (ou seja, exigindo um maior tempo de reação). Logo, a quantidade de borracha fina introduzida na mistura irá determinar o grau de modificação do ligante asfáltico. 


\subsection{2 - Estabilidade e Fluência Marshall}

Procurou-se avaliar a influência do teor de asfalto e da granulometria da borracha sobre as propriedades mecânicas das misturas envelhecidas em estufa por 2 horas. Para tanto, foram confeccionados corpos-de-prova contendo $1 \mathrm{e}$ $2 \%$ de borracha (em peso da mistura) nas granulometrias $\mathrm{G}(9,5 \mathrm{~mm}$ $0,60 \mathrm{~mm})$ e $\mathrm{F}(1,18 \mathrm{~mm}-0,15 \mathrm{~mm})$. As misturas $2 \mathrm{~F}^{\prime}, 2 \mathrm{G}^{\prime}$ e de controle foram dosadas para a obtenção de um volume de vazios de 4\%. As misturas $1 \mathrm{~F}, 1 \mathrm{G}$, $2 \mathrm{~F}$ e $2 \mathrm{G}$ foram moldadas utilizando a mesma quantidade de ligante da mistura de controle.

A Tabela 31 apresenta a composição das misturas, os valores de teor de asfalto, volume de vazios $\left(\mathrm{V}_{\mathrm{v}}\right)$, massa específica aparente $\left(\mathrm{D}_{\mathrm{ap}}\right)$, relação betume/vazios (RBV), fluência (F), estabilidade Marshall (E) e rigidez Marshall (kgf/mm). Esses valores representam a média de três corpos-deprova.

TABELA 31 - Resultados dos ensaios Marshall.

\begin{tabular}{lcccccccc}
\hline & \multicolumn{7}{c}{ Misturas } & NBR 12891 \\
\cline { 2 - 7 } & 2G' & $\mathbf{2 G}$ & $\mathbf{2 F ^ { \prime }}$ & $\mathbf{2 F}$ & $\mathbf{1 G}$ & $\mathbf{1 F}$ & Controle $\begin{array}{l}\text { Camada de } \\
\text { Rolamento }\end{array}$ \\
\hline Composição: & & & & & & & & \\
Agregado (g) & 1140 & 1140 & 1141,7 & 1141,7 & 1170 & 1170,8 & 1200 & - \\
Borracha (g) & 24 & 24 & 24 & 24 & 12 & 12 & - & - \\
CAP-20 (g) & 91,7 & 79,3 & 98,6 & 79,3 & 79,3 & 79,3 & 79,3 & - \\
\hline CAP-20 (\%) & 7,3 & 6,4 & 7,8 & 6,4 & 6,3 & 6,3 & 6,2 & - \\
$\mathrm{D}_{\text {ap }}$ & 2,365 & 2,344 & 2,356 & 2,325 & 2,399 & 2,387 & 2,469 & - \\
$\mathrm{V}_{\mathrm{v}}(\%)$ & 4 & 6,1 & 4 & 7,1 & 5,4 & 5,9 & 4 & $3-5$ \\
RBV (\%) & 80 & 69 & 83 & 67 & 73 & 71 & 79 & $75-82$ \\
E (kgf) & 937 & 978 & 872 & 1059 & 1219 & 1013 & 1399 & 350 \\
F (mm) & 5,2 & 4,7 & 5,1 & 4,5 & 4,5 & 4,1 & 3,2 & $2,0-4,6$ \\
E/F (kgf/mm) & 180 & 208 & 171 & 235 & 271 & 247 & 437 & - \\
\hline
\end{tabular}


O valor mínimo estabelecido para a estabilidade Marshall e a faixa de fluência variam de acordo com o órgão que faz a especificação. Todas as misturas apresentam valor de estabilidade superior ao mínimo estabelecido pelo DERSP (750 kg) e pela NBR 12891/93. Entretanto, as misturas 2G', 2G e 2F' não possuem valor de fluência dentro das especificações.

Deve-se destacar que o ensaio Marshall, apesar de questionado, ainda é uma referência no Brasil, motivo pelo qual foi incluído neste trabalho. Complementarmente, foram realizados ensaios para determinação do módulo de resiliência (DNER, 1994a) e resistência à tração por compressão diametral (DNER, 1994b).

\section{5 - Módulo de ResiliênCIA E RESistênCia À TraÇão}

$\mathrm{Na}$ fase dos ensaios exploratórios, procurou-se analisar a influência dos fatores granulometria de borracha (grossa, G, e fina, F) e envelhecimento de curto prazo (tempo de digestão) sobre os valores de MR e RT das misturas modificadas.

A Tabela 32 apresenta os valores de módulo de resiliência e resistência à tração para misturas virgens (moldagem imediata) e submetidas à simulação de envelhecimento em estufa ( 2 horas a $150^{\circ} \mathrm{C}$ ) antes da compactação (média de 3 corpos-de-prova). Foram analisadas a mistura de controle e as misturas preparadas com $2 \%$ de borracha, moldadas com a mesma quantidade de ligante da mistura de controle ( $2 \mathrm{G}$ e $2 \mathrm{~F})$. 
TABELA 32 - Efeito do tempo de envelhecimento nos valores de MR e RT.

\begin{tabular}{lcccc}
\hline Mistura & Estufa a $\mathbf{1 5 0}^{\mathbf{0}} \mathbf{C}(\mathbf{h})$ & Vv (\%) & MR (MPa) & RT (MPa) \\
\hline \multirow{2}{*}{ Controle } & 0 & 3,9 & 3623 & 1,26 \\
& 2 & 4 & 3637 & 1,29 \\
\hline \multirow{2}{*}{$2 \mathrm{G}$} & 0 & 5,7 & 1853 & 0,93 \\
& 2 & 6,1 & 1634 & 1,02 \\
\hline \multirow{2}{*}{$2 \mathrm{~F}$} & 0 & 6,8 & 2230 & 0,93 \\
& 2 & 7,1 & 2104 & 0,99 \\
\hline
\end{tabular}

Quando se trabalha com misturas betuminosas, é freqüente a ocorrência de dispersão nos resultados dos ensaios, o que pode levar à interpretações errôneas quando são comparadas apenas as médias aritméticas. As Tabelas 33 e 34 apresentam, respectivamente, os resultados da análise de variância para as médias de MR e RT das amostras virgens e envelhecidas.

TABELA 33 - Análise de variância para MR de amostras virgens e envelhecidas.

\begin{tabular}{|c|c|c|c|c|c|c|c|}
\hline \multirow{3}{*}{$\begin{array}{l}\text { Mistura } \\
\text { Controle }-0 \mathrm{~h}\end{array}$} & \multicolumn{7}{|c|}{ Parâmetro } \\
\hline & \multicolumn{3}{|c|}{ Réplicas $\left(\mathrm{X}_{\mathrm{ij}}\right)$} & \multirow{2}{*}{$\frac{\text { Média }}{3623}$} & \multirow{2}{*}{$\begin{array}{c}\text { Desvio } \\
\text { Padrão }\end{array}$} & \multirow{2}{*}{$\frac{\sum X_{i j}}{10869}$} & \multirow{2}{*}{$\frac{\sum \mathrm{X}_{\mathrm{ij}}^{2}}{39450209}$} \\
\hline & 3433 & 3624 & 3812 & & & & \\
\hline Controle $-2 \mathrm{~h}$ & 3585 & 3673 & 3653 & 3637 & 46 & 10911 & 39687563 \\
\hline $2 \mathrm{G}-0 \mathrm{~h}$ & 2022 & 1814 & 1723 & 1853 & 153 & 5559 & 10347809 \\
\hline $2 G-2 h$ & 1748 & 1507 & 1648 & 1634 & 121 & 4903 & 8042457 \\
\hline $2 \mathrm{~F}-0 \mathrm{~h}$ & 2455 & 2043 & 2135 & 2211 & 216 & 6633 & 14759099 \\
\hline \multirow[t]{2}{*}{$2 F-2 h$} & 2138 & 2089 & 2085 & 2104 & 30 & 6312 & 13282190 \\
\hline & & & & & & $\mathrm{T}=45187$ & $Q=125569327$ \\
\hline $\begin{array}{l}\text { Fonte de } \\
\text { Variação }\end{array}$ & \multicolumn{2}{|c|}{$\begin{array}{c}\text { Soma dos } \\
\text { Quadrados }\end{array}$} & \multicolumn{2}{|c|}{$\begin{array}{c}\text { Graus de } \\
\text { Liberdade }\end{array}$} & $\begin{array}{c}\text { Quadrado } \\
\text { Médio }\end{array}$ & $\mathbf{F}$ & $\mathbf{F}_{\alpha=5 \%}$ \\
\hline Entre Amostras & \multicolumn{2}{|c|}{11884725,61} & \multicolumn{2}{|c|}{5} & 2376945,12 & & \\
\hline Residual & \multicolumn{2}{|c|}{247658,67} & \multicolumn{2}{|c|}{12} & 20638,22 & 115,17 & 3,11 \\
\hline Total & \multicolumn{2}{|c|}{12132384,28} & \multicolumn{2}{|c|}{17} & & & \\
\hline
\end{tabular}


TABELA 34 - Análise de variância para RT de amostras virgens e envelhecidas.

\begin{tabular}{|c|c|c|c|c|c|c|c|}
\hline \multirow{3}{*}{$\begin{array}{l}\text { Mistura } \\
\text { Controle }-0 \mathrm{~h}\end{array}$} & \multicolumn{7}{|c|}{ Parâmetro } \\
\hline & \multicolumn{3}{|c|}{ Réplicas $\left(X_{\mathrm{ij}}\right)$} & \multirow{2}{*}{$\frac{\text { Média }}{1,26}$} & \multirow{2}{*}{$\begin{array}{c}\text { Desvio } \\
\text { Padrão }\end{array}$} & \multirow{2}{*}{$\frac{\sum X_{i j}}{3,77}$} & \multirow{2}{*}{$\frac{\sum X_{\mathrm{ij}}^{2}}{4,74}$} \\
\hline & 1,25 & 1,29 & 1,23 & & & & \\
\hline Controle $-2 \mathrm{~h}$ & 1,25 & 1,33 & 1,29 & 1,29 & 0,04 & 3,87 & 5,00 \\
\hline $2 \mathrm{G}-0 \mathrm{~h}$ & 0,90 & 0,93 & 0,95 & 0,93 & 0,03 & 2,78 & 2,58 \\
\hline $2 G-2 h$ & 1,05 & 1,02 & 1,00 & 1,02 & 0,03 & 3,07 & 3,14 \\
\hline $2 \mathrm{~F}-0 \mathrm{~h}$ & 0,94 & 0,95 & 0,90 & 0,93 & 0,03 & 2,79 & 2,60 \\
\hline \multirow[t]{2}{*}{$2 \mathrm{~F}-2 \mathrm{~h}$} & 0,96 & 0,99 & 1,02 & 0,99 & 0,03 & 2,97 & 2,94 \\
\hline & & & & & & $\mathrm{T}=19,25$ & $Q=20,99$ \\
\hline $\begin{array}{l}\text { Fonte de } \\
\text { Variação }\end{array}$ & \multicolumn{2}{|c|}{$\begin{array}{c}\text { Soma dos } \\
\text { Quadrados }\end{array}$} & \multicolumn{2}{|c|}{$\begin{array}{c}\text { Graus de } \\
\text { Liberdade }\end{array}$} & $\begin{array}{l}\text { Quadrado } \\
\text { Médio }\end{array}$ & $\mathbf{F}$ & $\mathbf{F}_{\alpha=5 \%}$ \\
\hline Entre Amostras & \multicolumn{2}{|c|}{0,40} & \multicolumn{2}{|c|}{5} & 0,0792 & & \\
\hline Residual & \multicolumn{2}{|c|}{0,01} & \multicolumn{2}{|c|}{12} & 0,0009 & 87,98 & 3,11 \\
\hline Total & \multicolumn{2}{|c|}{0,41} & \multicolumn{2}{|c|}{17} & & & \\
\hline
\end{tabular}

As análises de variância, apresentadas nas Tabelas 33 e 34, mostram que existe diferença significativa de MR e RT entre as misturas virgens e envelhecidas, ao nível de 5\% de significância $\left(\mathrm{F}>\mathrm{F}_{\alpha=5 \%}\right)$. De acordo com o método de Tukey, são significativamente distintas as médias cujas diferenças são maiores que 394 para MR e 0,08 para RT. Os gráficos apresentados na Figura 38 facilitam a análise da comparação entre as amostras: "deslizandose" a reta (DIF) sobre as médias dos valores obtidos nos ensaios, pode-se analisar quais valores são estatisticamente diferentes. 

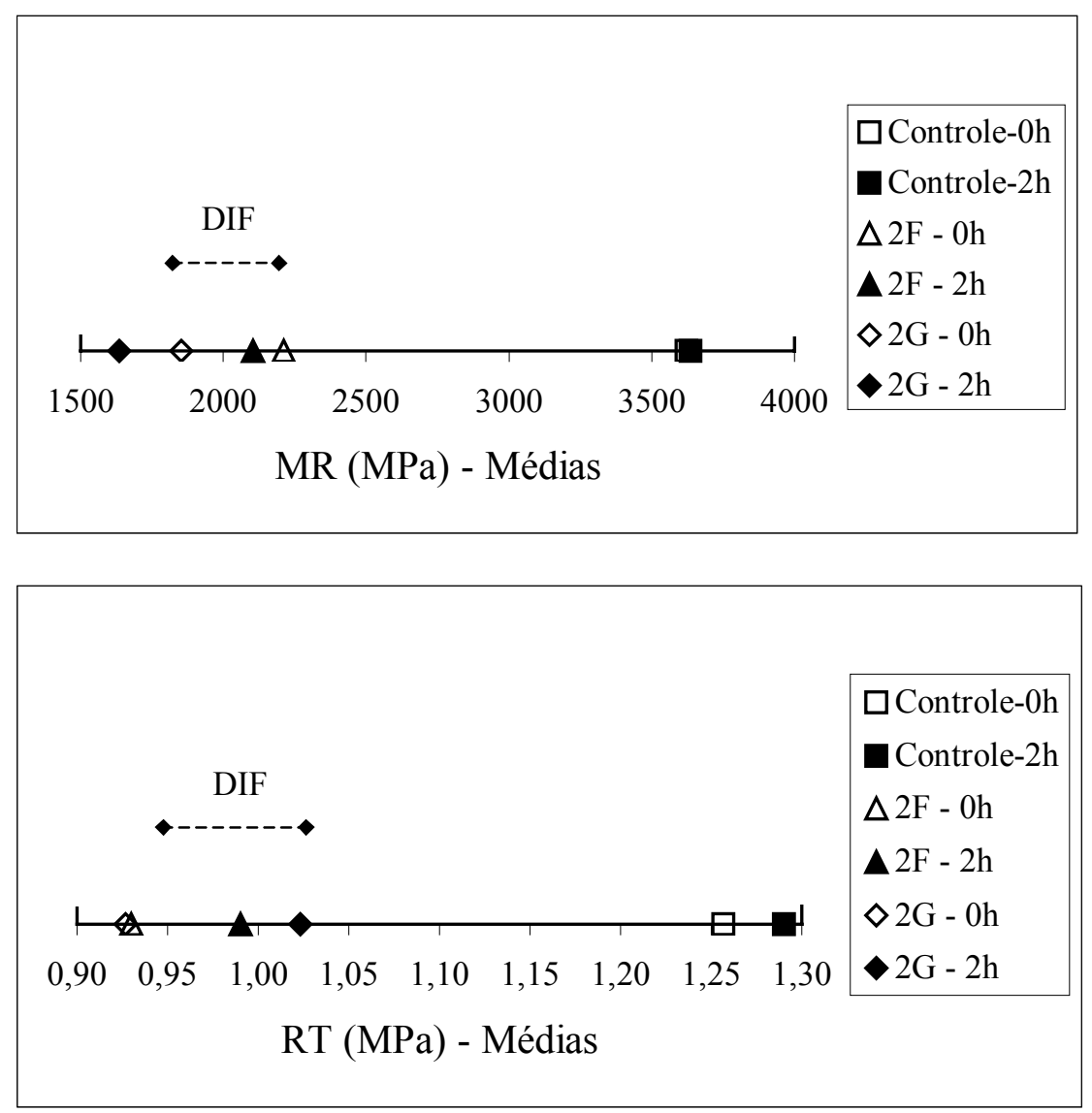

FIGURA 38 - Diferenças entre as médias de MR e RT para misturas virgens e envelhecidas (método de Tukey).

A Figura 38 mostra que existe diferença significativa nos valores de MR e RT entre as misturas modificadas e a mistura de controle. Analisando cada mistura isoladamente, observa-se que o envelhecimento não proporcionou alterações estatisticamente significativas nos valores de MR.

Para as misturas de controle e preparadas com $2 \%$ de borracha na granulometria fina (misturas 2F), os valores de RT não apresentaram diferenças estatisticamente significativas após o envelhecimento. Entretanto, a mistura preparada com $2 \%$ de borracha na granulometria $G$ (mistura 2G) apresentou aumento no valor de RT após o envelhecimento. 
Esse resultado ressalta a importância da consideração do tempo de digestão na análise das misturas modificadas com borracha pelo processo seco, principalmente quando são incorporadas partículas maiores de borracha. Com o envelhecimento, parece ocorrer a melhoria das propriedades mecânicas: o módulo de resiliência se mantém constante enquanto a resistência à tração aumenta. Neste caso, a diminuição dos valores das relações MR/RT é vantajosa, pois permitem a utilização de espessuras menores para uma mesma vida de fadiga.

Entretanto, é importante salientar a necessidade de estudos complementares, buscando-se variar o tempo e a temperatura durante o envelhecimento de curto prazo, além de um estudo para analisar o desempenho das misturas em longo prazo e a realização de ensaios para a determinação da vida de fadiga em misturas virgens e envelhecidas.

Em função dos resultados obtidos, optou-se por não considerar o fator tempo de envelhecimento no planejamento fatorial dos experimentos. Procurou-se analisar a influência dos fatores quantidade de borracha ( 1 e $2 \%$ em relação à massa total da mistura) e granulometria de borracha (grossa, $\mathrm{G}$ e fina, F) sobre os valores de MR e RT.

A Tabela 35 apresenta o resumo dos resultados (média de 3 corpos-de-prova) obtidos para módulo de resiliência (MR), resistência à tração (RT) e relação MR/RT para misturas submetidas ao envelhecimento em estufa por 2 horas a $150^{\circ} \mathrm{C}$ (resultados do experimento fatorial). A mistura de controle foi dosada para a obtenção de um teor de vazios de $4 \%$. As misturas $1 \mathrm{~F}, 1 \mathrm{G}, 2 \mathrm{~F}$ e $2 \mathrm{G}$ foram moldadas utilizando a mesma quantidade de ligante da mistura de controle. 
TABELA 35 - Resultados de MR, RT e relação MR/RT.

\begin{tabular}{lccccc}
\hline \multirow{2}{*}{ Parâmetro } & $\mathbf{5}$ & \multicolumn{5}{c}{ Misturas } \\
\cline { 2 - 6 } & $\mathbf{2 G}$ & $\mathbf{2 F}$ & $\mathbf{1 G}$ & $\mathbf{1 F}$ & Controle \\
\hline MR $\left(\mathrm{MPa}, 25^{\circ} \mathrm{C}\right)$ & 1634 & 2104 & 2165 & 2793 & 3637 \\
$\mathrm{RT}\left(\mathrm{MPa}, 25^{\circ} \mathrm{C}\right)$ & 1,02 & 0,99 & 1,14 & 1,11 & 1,29 \\
MR/RT & 1602 & 2125 & 1899 & 2516 & 2819 \\
\hline
\end{tabular}

As Tabelas 36 e 37 apresentam, respectivamente, os resultados da análise de variância para as médias de MR e RT.

TABELA 36 - Quadro da análise de variância para MR.

\begin{tabular}{|c|c|c|c|c|c|c|c|}
\hline \multirow{3}{*}{$\begin{array}{l}\text { Mistura } \\
\text { Controle }\end{array}$} & \multicolumn{7}{|c|}{ Parâmetro } \\
\hline & \multicolumn{3}{|c|}{ Réplicas $\left(\mathrm{X}_{\mathrm{ij}}\right)$} & \multirow{2}{*}{$\begin{array}{c}\text { Média } \\
3637\end{array}$} & \multirow{2}{*}{$\begin{array}{c}\begin{array}{c}\text { Desvio } \\
\text { Padrão }\end{array} \\
46\end{array}$} & \multirow{2}{*}{$\frac{\sum \mathrm{X}_{\mathrm{ij}}}{10911}$} & \multirow{2}{*}{$\frac{\sum X_{i j}^{2}}{39687563}$} \\
\hline & 3585 & 3673 & 3653 & & & & \\
\hline $1 \mathrm{G}$ & 1923 & 2299 & 2272 & 2165 & 210 & 6494 & 14145314 \\
\hline $2 \mathrm{G}$ & 1748 & 1507 & 1648 & 1634 & 121 & 4903 & 8042457 \\
\hline $1 \mathrm{~F}$ & 2732 & 2801 & 2844 & 2792 & 57 & 8377 & 23397761 \\
\hline \multirow[t]{2}{*}{$2 \mathrm{~F}$} & 2138 & 2089 & 2085 & 2104 & 30 & 6312 & 13282190 \\
\hline & & & & & & $\mathrm{T}=36997$ & $Q=98555285$ \\
\hline $\begin{array}{l}\text { Fonte de } \\
\text { Variação }\end{array}$ & \multicolumn{2}{|c|}{$\begin{array}{l}\text { Soma dos } \\
\text { Quadrados }\end{array}$} & \multicolumn{2}{|c|}{$\begin{array}{c}\text { Graus de } \\
\text { Liberdade }\end{array}$} & $\begin{array}{l}\text { Quadrado } \\
\text { Médio }\end{array}$ & $\mathbf{F}$ & $\mathbf{F}_{\alpha=5 \%}$ \\
\hline Entre Amostras & \multicolumn{2}{|c|}{7173745,73} & \multicolumn{2}{|c|}{4} & 1793436,43 & & \\
\hline Residual & \multicolumn{2}{|c|}{129672,00} & \multicolumn{2}{|c|}{10} & 12967,20 & 138,31 & 3,48 \\
\hline Total & \multicolumn{2}{|c|}{7303417,73} & \multicolumn{2}{|c|}{14} & & & \\
\hline
\end{tabular}


TABELA 37 - Quadro da análise de variância para RT.

\begin{tabular}{|c|c|c|c|c|c|c|c|}
\hline \multirow{3}{*}{$\begin{array}{l}\text { Mistura } \\
\text { Controle }\end{array}$} & \multicolumn{7}{|c|}{ Parâmetro } \\
\hline & \multicolumn{3}{|c|}{ Réplicas $\left(\mathrm{X}_{\mathrm{ij}}\right)$} & \multirow{2}{*}{$\begin{array}{c}\text { Média } \\
1,29\end{array}$} & \multirow{2}{*}{$\begin{array}{c}\begin{array}{c}\text { Desvio } \\
\text { Padrão }\end{array} \\
0,04\end{array}$} & \multirow{2}{*}{$\frac{\sum X_{i j}}{3,87}$} & \multirow{2}{*}{$\frac{\sum X_{\mathrm{ij}}^{2}}{5,00}$} \\
\hline & 1,25 & 1,33 & 1,29 & & & & \\
\hline $1 \mathrm{G}$ & 1,08 & 1,21 & 1,14 & 1,14 & 0,07 & 3,43 & 3,93 \\
\hline $2 \mathrm{G}$ & 1,05 & 1,02 & 1,00 & 1,02 & 0,03 & 3,07 & 3,14 \\
\hline $1 \mathrm{~F}$ & 1,13 & 1,05 & 1,16 & 1,11 & 0,06 & 3,34 & 3,73 \\
\hline \multirow[t]{2}{*}{$2 \mathrm{~F}$} & 0,96 & 0,99 & 1,02 & 0,99 & 0,03 & 2,97 & 2,94 \\
\hline & & & & & & $\mathrm{T}=16,68$ & $\mathrm{Q}=18,74$ \\
\hline $\begin{array}{l}\text { Fonte de } \\
\text { Variação }\end{array}$ & \multicolumn{2}{|c|}{$\begin{array}{l}\text { Soma dos } \\
\text { Quadrados }\end{array}$} & \multicolumn{2}{|c|}{$\begin{array}{c}\text { Graus de } \\
\text { Liberdade }\end{array}$} & $\begin{array}{c}\text { Quadrado } \\
\text { Médio }\end{array}$ & $\mathbf{F}$ & $\mathbf{F}_{\alpha=5 \%}$ \\
\hline Entre Amostras & \multicolumn{2}{|c|}{0,17} & \multicolumn{2}{|c|}{4} & 0,0416 & & \\
\hline Residual & \multicolumn{2}{|c|}{0,02} & \multicolumn{2}{|c|}{10} & 0,0021 & 19,60 & 3,48 \\
\hline Total & \multicolumn{2}{|c|}{0,19} & \multicolumn{2}{|c|}{14} & & & \\
\hline
\end{tabular}

As análises de variância, apresentadas nas Tabelas 36 e 37, revelaram que existe diferença significativa de MR e RT entre as misturas analisadas, ao nível de $5 \%$ de significância $\left(\mathrm{F}>\mathrm{F}_{\alpha=5 \%}\right)$. De acordo com o método de Tukey, são significativamente distintas as médias cujas diferenças são maiores que 305,71 para MR e 0,12 para RT. A Tabela 38 apresenta um resumo dos resultados das comparações entre as médias de MR e RT das misturas modificadas, considerando-se os fatores de interesse: teor de borracha e granulometria da borracha.

TABELA 38 - Comparação entre médias pelo método de Tukey, considerando-se os fatores de interesse.

\begin{tabular}{l|c|c}
\hline Método de Tukey & MR & RT \\
\hline $\mathrm{k}=5, \mathrm{u}=10, \mathrm{q}_{\alpha=5 \%}=4,65$ & $\mathrm{DIF}=305,71$ & $\mathrm{DIF}=0,12$ \\
\hline Fator Considerado & \multicolumn{2}{|c}{ Diferença entre Médias } \\
\hline \multirow{2}{*}{ Teor de borracha } & $|1 \mathrm{G}-2 \mathrm{G}|=531$ & $|1 \mathrm{G}-2 \mathrm{G}|=0,12$ \\
& $|1 \mathrm{~F}-2 \mathrm{~F}|=688$ & $|1 \mathrm{~F}-2 \mathrm{~F}|=0,12$ \\
\hline \multirow{2}{*}{ Granulometria da borracha } & $|2 \mathrm{G}-2 \mathrm{~F}|=470$ & $|2 \mathrm{G}-2 \mathrm{~F}|=0,03$ \\
& $|1 \mathrm{G}-1 \mathrm{~F}|=627$ & $|1 \mathrm{G}-1 \mathrm{~F}|=0,03$ \\
\hline
\end{tabular}



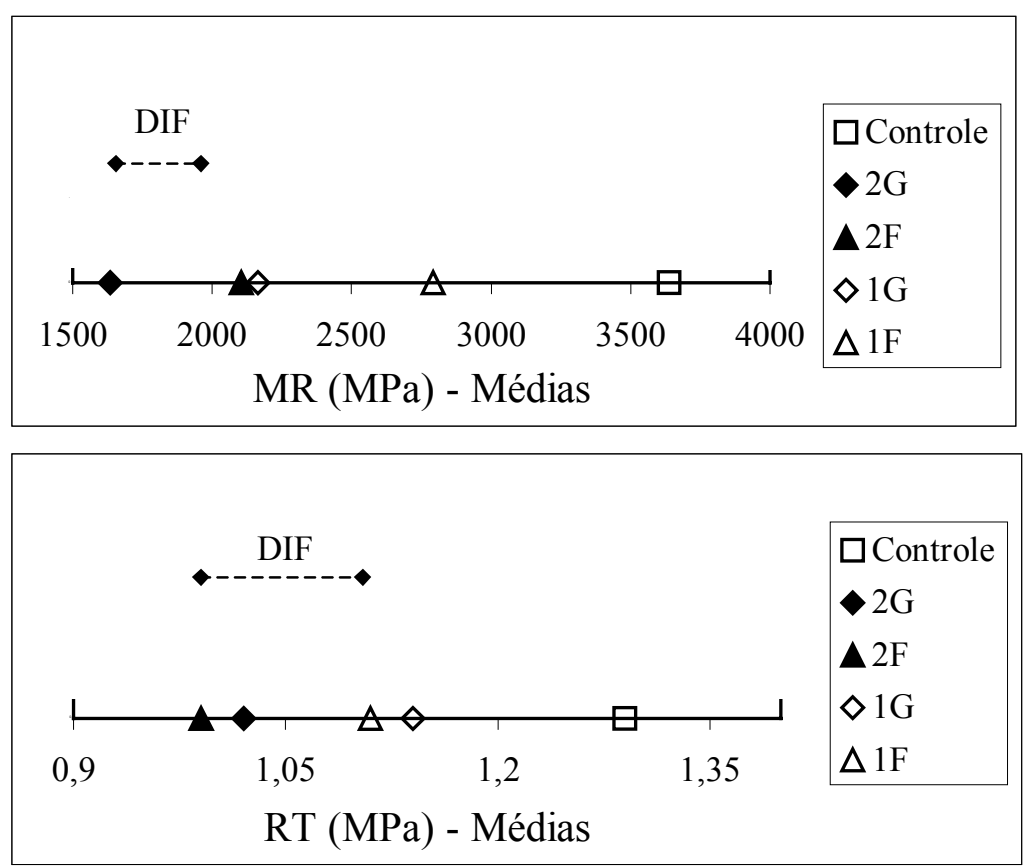

FIGURA 39 - Diferenças entre as médias de MR e RT (método de Tukey).

A Figura 39 apresenta os gráficos de comparação entre as amostras. Pode-se observar que existe diferença significativa nos valores de MR e RT entre as misturas modificadas e a mistura de controle. Todas as misturas contendo borracha apresentaram valores de MR estatisticamente diferentes, mostrando que os fatores granulometria de borracha e quantidade de borracha influenciaram nos resultados de módulo de resiliência nas misturas modificadas. Quanto à granulometria da borracha, as misturas modificadas apresentaram valores de RT estatisticamente iguais (o fator granulometria não influiu nos resultados de RT).

A análise de variância mostra quais os fatores que influenciam nos resultados de MR e RT, mas não permite quantificar essa influência. O planejamento fatorial permite quantificar essa influência, além de verificar a existência de interação entre os fatores. O item 6.9 desse capítulo apresenta os resultados da análise de variância para o experimento fatorial realizado. 


\section{6 - DeformaÇão Permanente em Equipamento Simulador de TrÁFEGO}

Em alguns países, principalmente Estados Unidos e França, os equipamentos simuladores de tráfego em laboratório estão sendo utilizados na dosagem das misturas asfálticas (COOLEY JR. et al., 2000; BROWN et al., 2001). A limitação da deformação permanente nas trilhas de roda tem sido utilizada como critério de aceitação das misturas asfálticas. A norma francesa NF P 98253-1 (AFNOR, 1991a) fixa em 5\% o limite máximo de afundamento na trilha de roda, após 30.000 ciclos, em revestimentos submetidos a tráfego muito pesado e em $10 \%$ para tráfego leve.

Os ensaios foram realizados com temperatura controlada de $60^{\circ} \mathrm{C}$ e os resultados representam a média entre duas placas. Todas as misturas foram submetidas à simulação de envelhecimento em estufa (2 horas a $\left.150^{\circ} \mathrm{C}\right)$ anteriormente à compactação das placas.

Buscando analisar a influência do teor de asfalto no desenvolvimento da deformação permanente nas trilhas de roda, foram moldadas placas fixando-se o valor de volume de vazios em 4\% (mistura de controle, $2 F^{\prime}$ e $2 G^{\prime}$ ) e, numa segunda etapa, repetiu-se esse procedimento na moldagem das misturas $1 \mathrm{~F}$, $1 \mathrm{G}, 2 \mathrm{~F}$ e $2 \mathrm{G}$ utilizando a mesma quantidade de ligante adicionada à mistura de controle.

A Figura 40 apresenta a variação da porcentagem de afundamento em trilha de roda com o número de ciclos para a mistura de controle e as misturas preparadas com $2 \%$ de borracha nas granulometrias G (Figura 42a - Controle x $2 \mathrm{G}$ x $2 \mathrm{G}^{\prime}$ ) e F (Figura 42b - Controle x 2F x 2F'). 


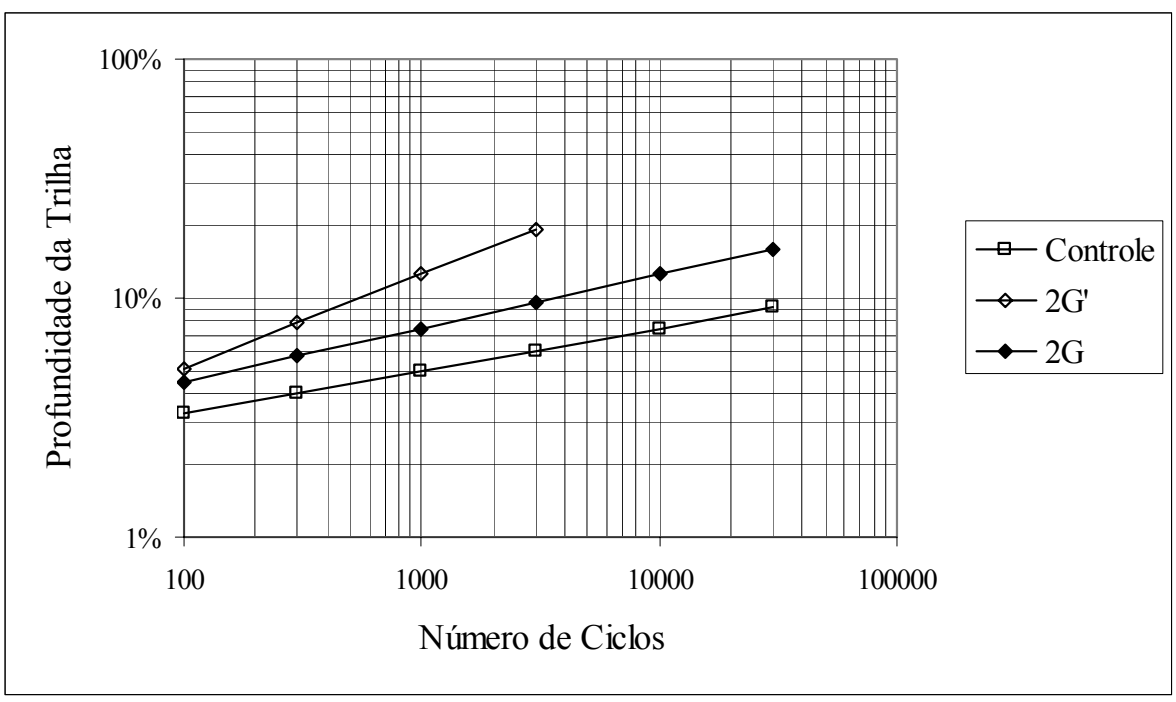

(a) Mistura com 2\% de borracha na granulometria grossa $(\mathrm{G})$

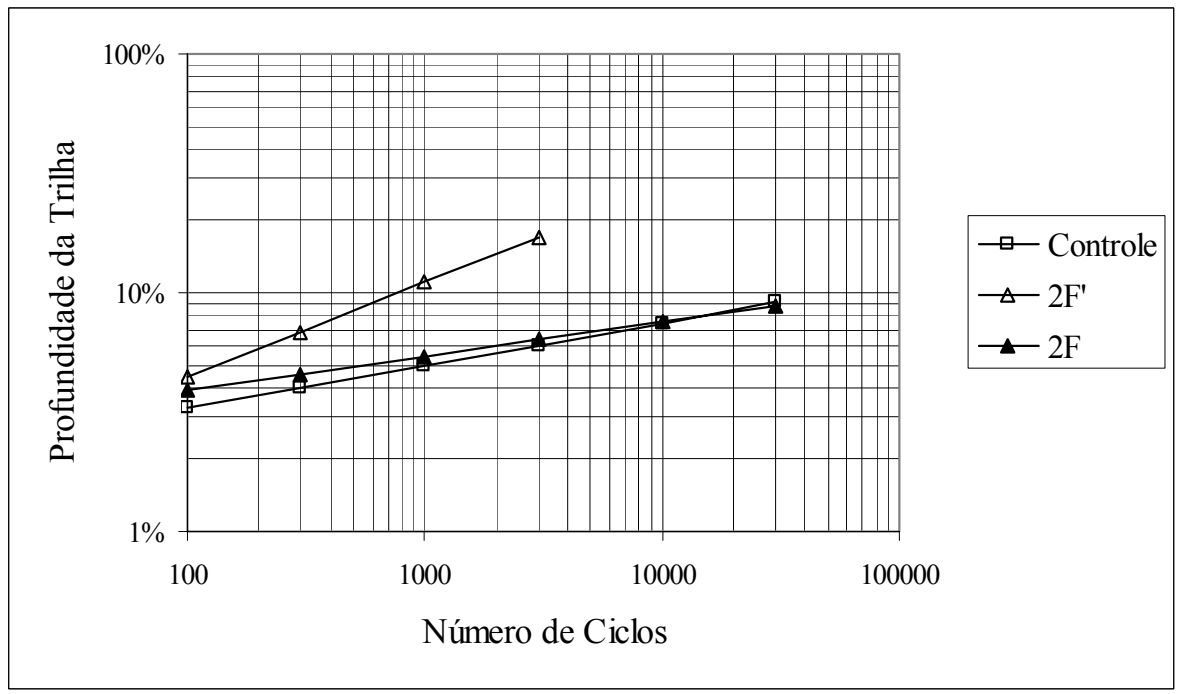

(b) Mistura com 2\% de borracha na granulometria fina (F).

FIGURA 40 - Influência do teor de ligante no afundamento em trilha de roda.

As misturas modificadas com adição de borracha dosadas para um volume de vazios de 4\% apresentaram deformação permanente excessiva e precoce: após 3.000 ciclos, a mistura $2 \mathrm{G}^{\prime}$ deformou $19,5 \%$ e a mistura $2 \mathrm{~F}^{\prime}$ deformou $17 \%$ Isso indica que os teores de ligante utilizados são extremamente elevados para essas misturas e que o volume de vazios não deve ser usado como critério na determinação do teor ótimo de ligante para essas misturas. 
A Figura 41 apresenta a variação da porcentagem de afundamento em trilha de roda com o número de ciclos para a mistura de controle e as misturas preparadas com $2 \%$ de borracha nas granulometrias $\mathrm{G}$ e $\mathrm{F}$, ambas moldadas com a mesma quantidade de ligante da mistura de controle. Procurou-se analisar como a granulometria da borracha influencia a evolução do afundamento nas trilhas de roda.

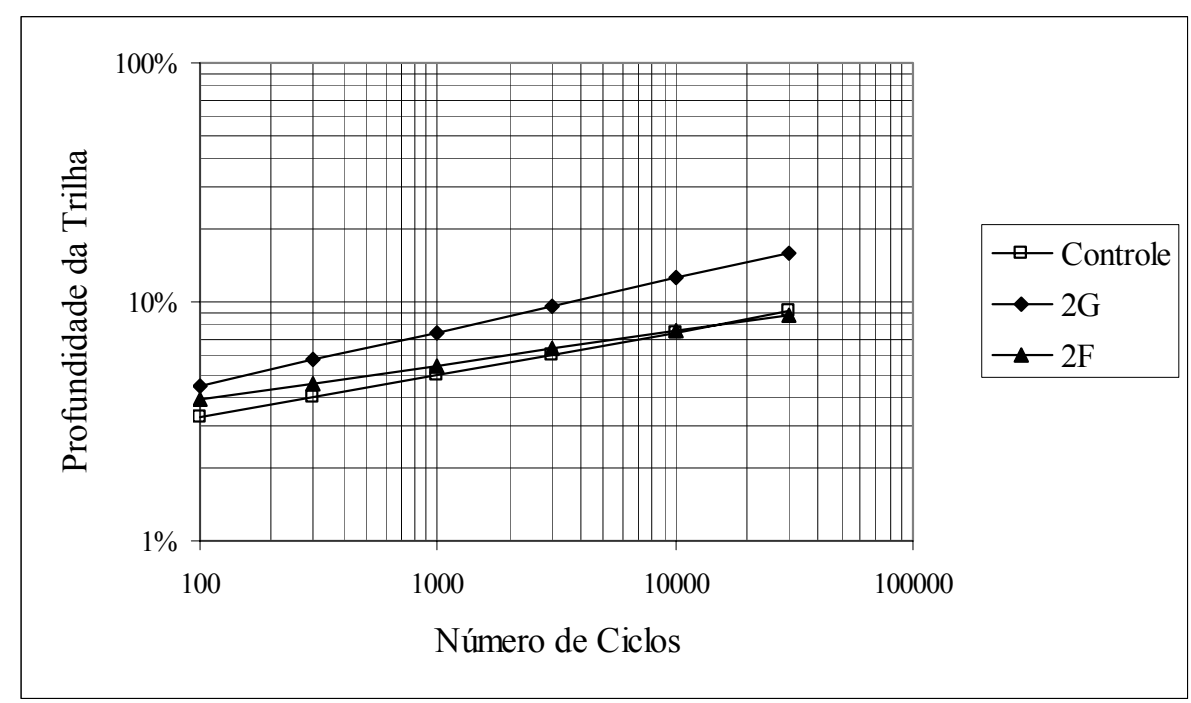

FIGURA 41 - Influência da granulometria da borracha ( $\left(\begin{array}{lll}\mathrm{x} & \mathrm{F}\end{array}\right)$ no afundamento em trilha de roda.

A diminuição do tamanho das partículas de borracha proporciona uma melhora de desempenho em termos de resistência à deformação permanente: a mistura com borracha na granulometria $\mathrm{G}$ apresenta afundamento na trilha de roda, após 30.000 ciclos, de 16,0\% enquanto as misturas com borracha na granulometria $\mathrm{F}$ e de controle apresentam deformação em torno de $9 \%$. Entretanto, a mistura $2 \mathrm{~F}$ apresenta curva menos inclinada em relação à mistura de controle, expressando a menor potencialidade de desenvolvimento de deformação permanente com o número de ciclos. 
A Figura 42 apresenta a variação da porcentagem de afundamento em trilha de roda com o número de ciclos para a mistura de controle e as misturas preparadas com 1 e $2 \%$ de borracha nas granulometrias G e F. As misturas com borracha foram moldadas com a mesma quantidade de ligante da mistura de controle. Procurou-se analisar como a quantidade de borracha influencia a evolução do afundamento nas trilhas de roda.

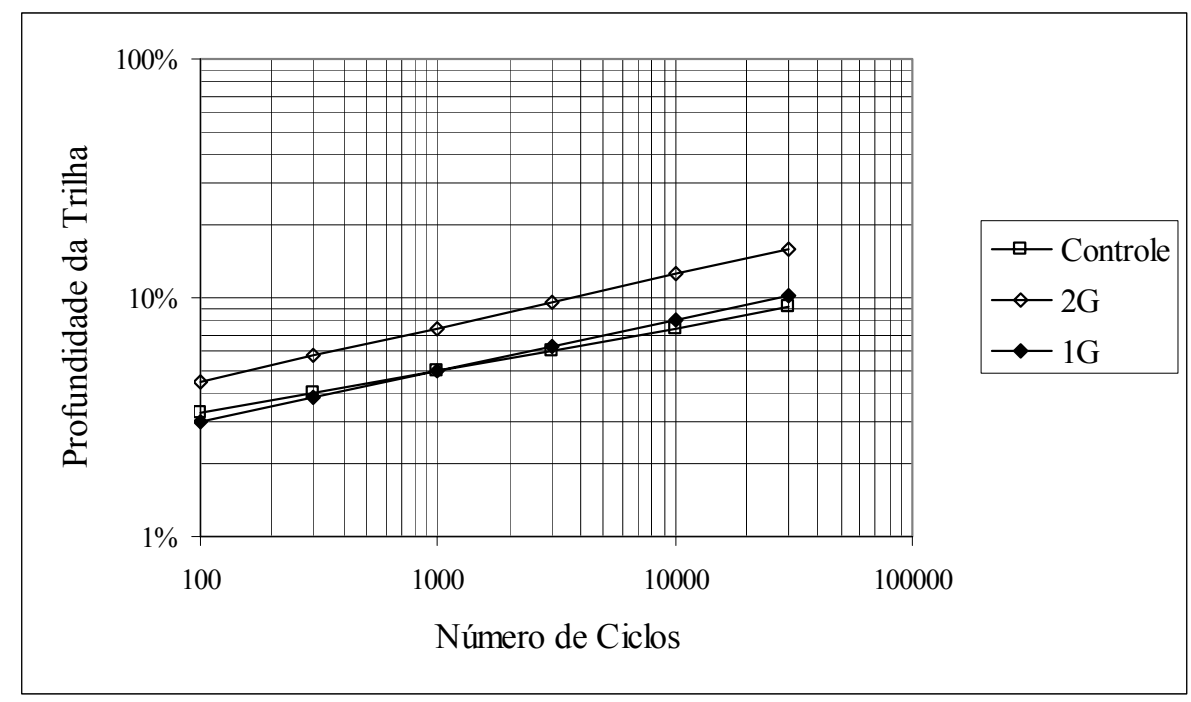

(a) Mistura com 1 e $2 \%$ de borracha na granulometria $\mathrm{G}$

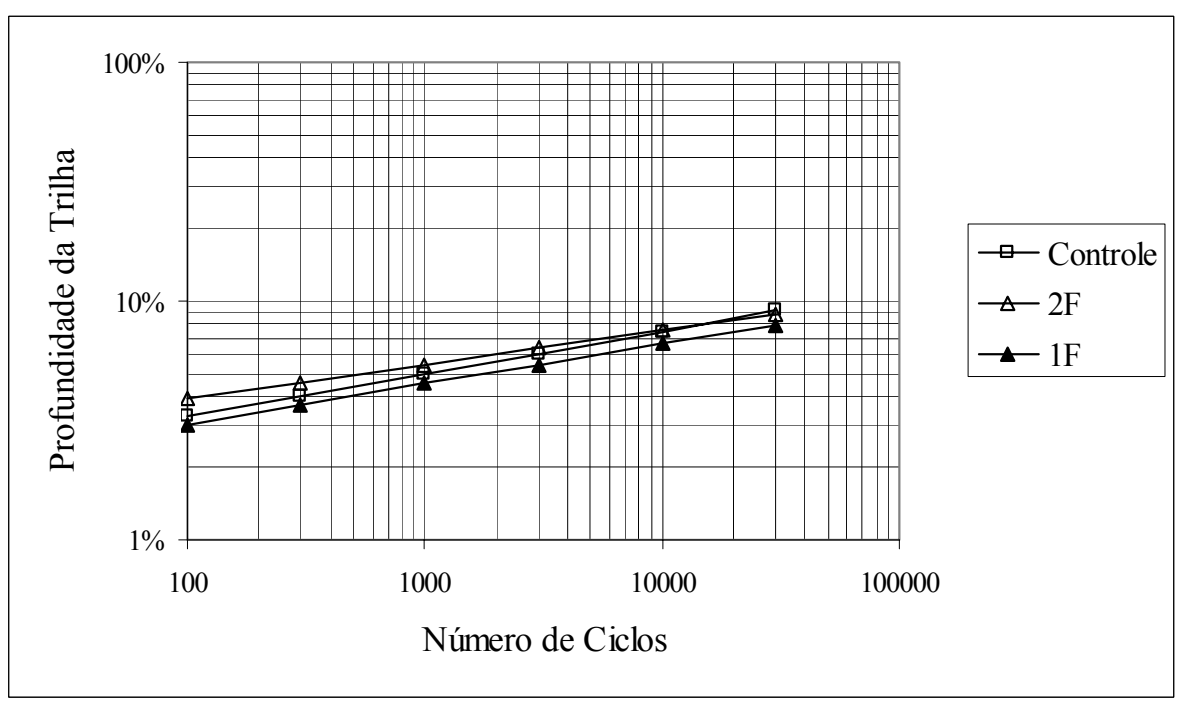

(b) Mistura com 1 e $2 \%$ de borracha na granulometria $\mathrm{F}$

FIGURA 42 - Influência da quantidade da borracha no afundamento em trilha de roda. 
A incorporação de $1 \%$ borracha na granulometria G (Figura 42a) e de $2 \%$ de borracha na granulometria F (Figura 42b) não compromete o desempenho das misturas, em termos de deformação permanente. A incorporação de pequenos teores $(1 \%)$ de borracha na granulometria fina proporcionou efeito benéfico, melhorando o desempenho em termos de resistência à deformação permanente quando comparado à mistura de controle.

A Tabela 39 apresenta o resumo dos resultados do ensaio de trilha de roda (média entre duas placas ensaiadas) para todas as misturas analisadas. $\mathrm{O}$ coeficiente angular é obtido através da equação de regressão de cada mistura e representam a taxa de deformação com o número de ciclos.

TABELA 39 - Resultados obtidos no ensaio de deformação permanente em trilha de roda.

\begin{tabular}{|c|c|c|c|c|c|c|c|}
\hline \multirow{2}{*}{ Parâmetro } & \multicolumn{7}{|c|}{ Misturas } \\
\hline & $2 \mathbf{G}^{\prime}$ & $2 \mathrm{G}$ & $2 F^{\prime}$ & $2 \mathbf{F}$ & $1 G$ & $1 F$ & Controle \\
\hline CAP-20 (\%) & 7,3 & 6,4 & 7,8 & 6,4 & 6,3 & 6,3 & 6,2 \\
\hline $\mathrm{V}_{\mathrm{v}}(\%)$ & 4 & 6,1 & 4 & 7,1 & 5,4 & 5,9 & 4 \\
\hline \multicolumn{8}{|c|}{ Afundamento em trilha de roda (\%): } \\
\hline 1.000 ciclos & 12,6 & 7,5 & 11,0 & 5,4 & 4,9 & 4,5 & 5,0 \\
\hline 10.000 ciclos & $*$ & 12,5 & $*$ & 7,6 & 8,0 & 6,6 & 7,5 \\
\hline 30.000 ciclos & $*$ & 16,0 & * & 8,9 & 10,1 & 8,0 & 9,1 \\
\hline Coeficiente Angular & 0,3960 & 0,2234 & 0,3950 & 0,1451 & 0,2129 & 0,1681 & 0,1789 \\
\hline
\end{tabular}

*O ensaio foi finalizado após 3.000 ciclos devido à deformação excessiva.

Pelos resultados apresentados nas Figuras 40, 41, 42 e Tabela 39, quanto à resistência ao acúmulo de deformação permanente nas trilhas de roda, as misturas que apresentaram melhores desempenhos foram as com granulometria fina e teor de ligante igual ao da mistura de controle (1F e $2 \mathrm{~F})$, 
seguidas pela mistura de controle. As misturas $1 \mathrm{~F}$ e $2 \mathrm{~F}$ apresentaram menores taxas de deformação (curvas menos inclinadas) quando comparadas à mistura de controle, ou seja, essas misturas apresentam menor potencial de desenvolver deformação permanente nas trilhas de roda.

A mistura com pior desempenho foi a com granulometria grossa e teor de ligante correspondente a um volume de vazios de aproximadamente 4\% (2G'), seguida pela $2 \mathrm{~F}^{\prime}$ (granulometria fina, teor para $\mathrm{Vv}=4 \%$ ) e $2 \mathrm{G}$ (granulometria grossa e teor igual ao da mistura de controle).

Os resultados dos ensaios de trilha de roda indicam, nas misturas modificadas e dosadas para um volume de vazios de $4 \%$, que a quantidade elevada de ligante pode causar a falência precoce do revestimento, com a ocorrência de deformação permanente excessiva. O Apêndice 3 contém os resultados completos dos ensaios de trilha de roda realizados neste trabalho.

\section{7 - UMIDADE INDUZIDA}

O método de ensaio AASHTO T-283 recomenda a moldagem de corpos-deprova com volume de vazios entre 6 e $8 \%$, que são obtidos ajustando-se o número de golpes durante a compactação.

Na compactação dos corpos-de-prova da mistura de controle reduziu-se o número de golpes por face para aproximadamente 15 golpes, para a obtenção de um volume de vazios entre 6 e $8 \%$. A Tabela 40 apresenta o resultado do ensaio de resistência da mistura de controle a danos por umidade induzida (média de três corpos-de-prova para cada condição). 
TABELA 40 - Resultado do ensaio de umidade induzida para a mistura de controle.

\begin{tabular}{llllcc}
\hline Mistura & Condição & Vv (\%) & RT & $\frac{\mathbf{R T}_{\text {saturado }}}{\mathbf{R T}_{\text {seco }}}$ & Especificação \\
\hline \multirow{2}{*}{ Controle } & Seco & 6,3 & 1,10 & $92 \%$ & $>70 \%$ \\
& Saturado & 6,4 & 1,02 & & \\
\hline
\end{tabular}

O resultado indica que a mistura de controle compactada não apresenta problemas de adesividade entre agregado e ligante. Cabe observar que na fase de caracterização dos agregados pétreos foram realizados ensaios de adesividade para agregados graúdos (DNER ME 78/94) e miúdos (DNER ME 79/94), obtendo-se uma adesividade não satisfatória para o agregado utilizado.

As misturas $2 \mathrm{G}$ e $2 \mathrm{~F}$, preparadas com a mesma quantidade de ligante adicionada à mistura de controle, apresentaram volume de vazios no intervalo entre $6 \%$ e $8 \%$ após 75 golpes do soquete compactador. Entretanto, essas misturas quando imersas e submetidas ao vácuo, não atingiram o grau de saturação mínimo necessário à realização do ensaio (saturação < 55\%). Esse fato salienta a necessidade de um estudo mais aprofundado sobre a permeabilidade dos pavimentos que contém borracha triturada.

COOLEY JR. (1999) destaca que a permeabilidade dos pavimentos é influenciada pelo tamanho, orientação e interconexão dos vazios, não dependendo apenas do teor de vazios. 


\section{8 - Perda de Massa no Ensaio CÂntabro}

O ensaio Cântabro foi concebido para avaliar a resistência à desagregação de misturas asfálticas abertas, sendo considerado neste trabalho como uma tentativa de verificar se a adição de borracha proporciona algum beneficio às misturas asfálticas. A Figura 43 apresenta os resultados da perda de massa no ensaio Cântabro (média de 3 corpos-de-prova). Todas as misturas foram submetidas ao envelhecimento em estufa por 2 horas a $150^{\circ} \mathrm{C}$ anteriormente à compactação. As misturas de controle, $2 \mathrm{G}^{\prime}$ e $2 \mathrm{~F}^{\prime}$ foram dosadas para obtenção de um volume de vazios de $4 \%$. As outras misturas foram moldadas com a mesma quantidade de ligante da mistura de controle.

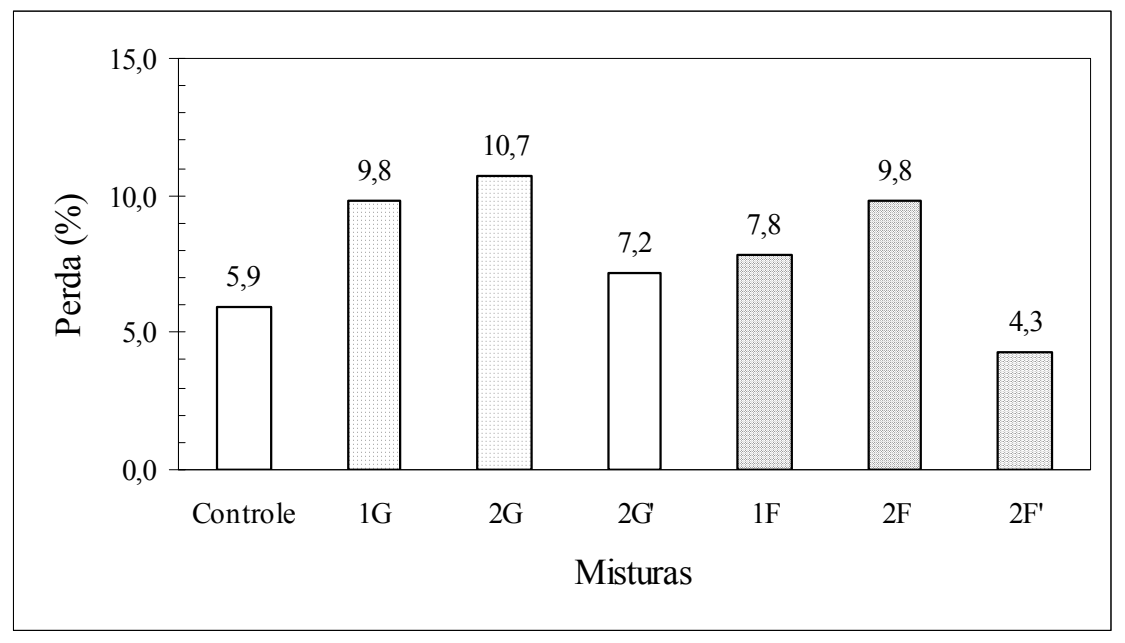

FIGURA 43 - Resultados do ensaio Cântabro.

A análise de variância apresentada na Tabela 41 indica que existe diferença significativa de perda de massa entre as misturas, ao nível de $5 \%$ de significância $\left(F>F_{\alpha=5 \%}\right)$. 
TABELA 41 - Análise de variância para perda de massa no ensaio Cântabro.

\begin{tabular}{|c|c|c|c|c|c|c|c|}
\hline \multirow{3}{*}{$\begin{array}{l}\text { Mistura } \\
\text { Controle }\end{array}$} & \multicolumn{7}{|c|}{ Parâmetro } \\
\hline & \multicolumn{3}{|c|}{ Réplicas $\left(\mathrm{X}_{\mathrm{ij}}\right)$} & Média & \multirow{2}{*}{$\begin{array}{c}\begin{array}{c}\text { Desvio } \\
\text { Padrão }\end{array} \\
1,2\end{array}$} & \multirow{2}{*}{$\frac{\sum X_{i j}}{17,55}$} & \multirow{2}{*}{$\frac{\sum \mathrm{X}_{\mathrm{ij}}^{2}}{105,52}$} \\
\hline & 4,8 & 5,6 & 7,2 & 5,9 & & & \\
\hline $1 \mathrm{G}$ & 9,6 & 9,5 & 10,4 & 9,8 & 0,5 & 29,50 & 290,57 \\
\hline $2 \mathrm{G}$ & 10,7 & 11,7 & 9,8 & 10,7 & 1,0 & 32,20 & 347,42 \\
\hline $2 \mathrm{G}^{\prime}$ & 7,6 & 8,4 & 5,5 & 7,2 & 1,5 & 21,50 & 158,57 \\
\hline $1 \mathrm{~F}$ & 8,4 & 8,0 & 6,9 & 7,8 & 0,8 & 23,30 & 182,17 \\
\hline $2 \mathrm{~F}$ & 9,8 & 8,9 & 10,7 & 9,8 & 0,9 & 29,40 & 289,74 \\
\hline \multirow[t]{2}{*}{$2 \mathrm{~F}^{\prime}$} & 5,7 & 3,6 & 3,5 & 4,3 & 1,2 & 12,80 & 57,70 \\
\hline & & & & & & $\mathrm{T}=166,25$ & $\mathrm{Q}=1431,69$ \\
\hline $\begin{array}{l}\text { Fonte de } \\
\text { Variação } \\
\end{array}$ & \multicolumn{2}{|c|}{$\begin{array}{c}\text { Soma dos } \\
\text { Quadrados } \\
\end{array}$} & $\begin{array}{c}\text { Graus de } \\
\text { Liberdade }\end{array}$ & \multicolumn{2}{|c|}{$\begin{array}{c}\text { Quadrado } \\
\text { Médio }\end{array}$} & $\mathbf{F}$ & $\mathbf{F}_{\alpha=5 \%}$ \\
\hline Entre Amostras & \multicolumn{2}{|c|}{100,00} & 6 & \multicolumn{2}{|r|}{16,67} & & \\
\hline Residual & \multicolumn{2}{|c|}{15,55} & 14 & \multicolumn{2}{|r|}{1,11} & 15,01 & 2,85 \\
\hline Total & \multicolumn{2}{|c|}{115,55} & 20 & & & & \\
\hline
\end{tabular}

De acordo com o método de Tukey, são significativamente distintas as médias cujas diferenças são maiores que 2,94 para a perda de massa (Tabela 43). A Figura 44 apresenta o gráfico de comparação entre as médias.

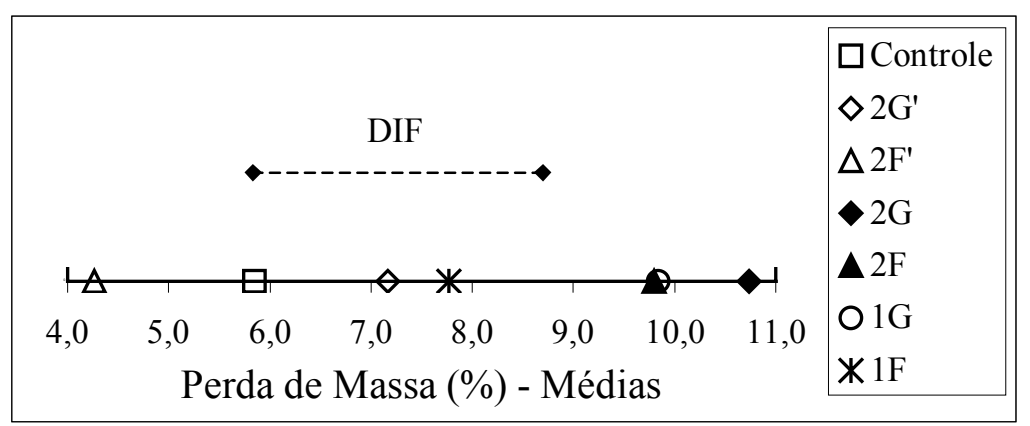

FIGURA 44 - Diferenças entre as médias de perda de massa (método de Tukey). 
As misturas 2G', 2F' e $1 \mathrm{~F}$ apresentam valores de perda de massa no ensaio Cântabro estatisticamente iguais à mistura de controle. As misturas 2G, $1 \mathrm{G}$ e 2F apresentaram o maior percentual de perda em relação à mistura de controle.

A Tabela 42 apresenta um resumo dos resultados das comparações entre as médias de perda de massa nas misturas modificadas, considerando-se diferentes fatores.

TABELA 42 - Comparação entre médias de perda de massa (ensaio Cântabro) pelo método de Tukey, considerando-se os fatores de interesse.

\begin{tabular}{l|c}
\hline Método de Tukey & Perda de Massa (\%) \\
\hline $\mathrm{k}=7, \mathrm{u}=14, \mathrm{q}_{\alpha=5 \%}=4,83$ & $\mathrm{DIF}=2,94$ \\
\hline Fator Considerado & Diferença entre Médias \\
\hline Teor de Ligante & $\left|2 \mathrm{G}^{\prime}-2 \mathrm{G}\right|=3,50$ \\
\hline Teor de borracha & $\left|2 \mathrm{~F}^{\prime}-2 \mathrm{~F}\right|=5,50$ \\
\hline \multirow{2}{*}{ Granulometria da borracha } & $|1 \mathrm{G}-2 \mathrm{G}|=0,90$ \\
& $|1 \mathrm{~F}-2 \mathrm{~F}|=2,00$ \\
\hline
\end{tabular}

As misturas modificadas e dosadas para obtenção de um volume de vazios de $4 \%$ (misturas 2F' e 2G') apresentaram menor perda de massa quando comparadas às misturas dosadas com o mesmo teor de ligante da mistura de controle (misturas $2 \mathrm{~F}$ e $2 \mathrm{G}$ ). Esse resultado era esperado uma vez que uma maior quantidade de ligante proporciona um maior recobrimento dos agregados, aumentando a resistência à desagregação das misturas.

Com este ensaio não foi possível avaliar, através de análise comparativa, qual a influência da granulometria e do teor de borracha na resistência à desagregação, uma vez que as diferenças entre as misturas modificadas não se refletiram nos resultados dos ensaios, conforme mostra a Tabela 42. 


\section{9 - EXPERIMENTO FATORIAL: ANÁLISE ESTATÍSTICA}

Apresenta-se a análise estatística dos efeitos dos fatores granulometria da borracha (G) e teor de borracha (T) sobre o desempenho das misturas asfálticas, visando a identificação dos fatores e interações significativos e a obtenção de modelos que representem seus efeitos sobre as variáveis dependentes (módulo de resiliência, resistência à tração e deformação permanente nas trilhas de roda).

No experimento fatorial, os fatores considerados e os níveis correspondentes passam a ser representados por:

- Fator T: Teor de borracha

nível t.: $1 \%$

nível $t_{+}: 2 \%$

- Fator G: Granulometria da borracha

nível g.: F

nível $g_{+}: \mathrm{G}$

A Tabela 43 apresenta a matriz de planejamento com efeitos de interação para o experimento fatorial realizado. Aplicou-se a Análise de Variância (ANOVA) para quantificar a influência de cada fator e verificar a existência de interações entre os fatores.

TABELA 43 - Matriz de planejamento com efeitos de interação.

\begin{tabular}{|c|c|c|c|}
\hline \multirow{2}{*}{ Teste } & \multicolumn{2}{|c|}{ Fatores de Controle } & \multirow{2}{*}{ Efeitos da Interação } \\
\hline & $\mathbf{T}$ & $\mathbf{G}$ & \\
\hline $1(2 \mathrm{G})$ & + & + & + \\
\hline $2(2 \mathrm{~F})$ & + & - & - \\
\hline $3(1 \mathrm{G})$ & - & + & - \\
\hline $4(1 \mathrm{~F})$ & - & - & + \\
\hline
\end{tabular}




\subsection{1 - Cálculo das Variâncias}

O quadro de análise de variância para um experimento de dois fatores é construído conforme mostrado na Tabela 44.

TABELA 44 - Quadro de análise de variância (ANOVA) para um experimento com 2 fatores.

\begin{tabular}{lcccc}
\hline $\begin{array}{l}\text { Fatores e } \\
\text { Interações }\end{array}$ & $\begin{array}{c}\text { Soma dos } \\
\text { Quadrados }\end{array}$ & $\begin{array}{c}\text { Graus de } \\
\text { Liberdade }\end{array}$ & Quadrado Médio & Teste F \\
\hline Fator T & $\mathrm{SQ}_{\mathrm{T}}$ & $a-1$ & $\mathrm{QM}_{\mathrm{T}}=\mathrm{SQ}_{\mathrm{T}} /(a-1)$ & $\mathrm{QM}_{\mathrm{T}} / \mathrm{QM}_{\mathrm{R}}$ \\
Fator G & $\mathrm{SQ}_{\mathrm{G}}$ & $b-1$ & $\mathrm{QM}_{\mathrm{G}}=\mathrm{SQ}_{\mathrm{G}} /(b-1)$ & $\mathrm{QM}_{\mathrm{G}} / \mathrm{QM}_{\mathrm{R}}$ \\
Interação & $\mathrm{SQ}_{\mathrm{TG}}$ & $(a-1)(b-1)$ & $\mathrm{QM}_{\mathrm{TG}}=\mathrm{SQ}_{\mathrm{TG}} /(a-1)(b-1)$ & $\mathrm{QM}_{\mathrm{TG}} / \mathrm{QM}_{\mathrm{R}}$ \\
\hline Resíduo & $\mathrm{SQ}_{\mathrm{R}}$ & $a b(n-1)$ & $\mathrm{QM}_{\mathrm{R}}=\mathrm{SQ}_{\mathrm{R}} / a b(n-1)$ & \\
\hline Total & $\mathrm{SQ}_{\text {TотАL }}$ & $a b n-1$ & & \\
\hline
\end{tabular}

Onde $a$ e $b$ representam o número de níveis dos fatores T e $\mathrm{G}$ e $n$, o número de réplicas.

Os próximos itens apresentam um roteiro para o cálculo das variâncias de cada fator e interação.

\section{a) Soma de Quadrados}

A soma dos quadrados total é calculada pela expressão:

$$
\mathrm{SQ}_{\text {total }}=\Sigma \mathrm{x}^{2}-\mathrm{C}
$$

onde:

$$
\begin{aligned}
& \mathrm{x}=\text { observação } \\
& \mathrm{C}=\frac{(\Sigma \mathrm{x})^{2}}{\mathrm{n}} \\
& \mathrm{n}=\text { número de observações }
\end{aligned}
$$




\section{b) Fatores $\mathbf{T}$ e $\mathbf{G}$}

Para o fator T, que apresenta dois níveis, a soma dos quadrados é calculada pela expressão:

$$
\mathrm{SQ}_{\mathrm{T}}=\frac{\left(\mathrm{t}_{2}-\mathrm{t}_{1}\right)^{2}}{\mathrm{r} \cdot \mathrm{t}^{\prime \prime} \cdot \mathrm{g}^{\prime}}
$$

onde:

$\mathrm{t}_{2}=$ somatório das observações em que $\mathrm{T}$ apresenta o nível $\mathrm{t}_{+}(2 \%)$

$\mathrm{t}_{1}=$ somatório das observações em que T apresenta o nível $\mathrm{t}_{\text {. }}(1 \%)$

$\mathrm{r}=$ número de réplicas

$\mathrm{t}^{\prime \prime}=(-1)^{2}+(+1)^{2}=2$

$\mathrm{g}^{\prime}=$ número de níveis do fator $\mathrm{G}$

A soma dos quadrados para o fator $\mathrm{G}$ é calculada de maneira análoga.

\section{c) Interação entre os Fatores $\mathbf{T}$ e G}

A soma dos quadrados das interações entre fatores com dois níveis pode ser calculada de acordo com as expressões:

$$
\mathrm{SQ}_{\mathrm{TG}}=\frac{\left(\mathrm{t}_{2} \cdot \mathrm{g}_{2}-\mathrm{t}_{1} \cdot \mathrm{g}_{2}-\mathrm{t}_{2} \cdot \mathrm{g}_{1}+\mathrm{t}_{1} \cdot \mathrm{g}_{1}\right)^{2}}{\mathrm{r} \cdot(\mathrm{t} \cdot \mathrm{g})^{\prime \prime}}
$$

onde:

$\mathrm{t}_{2} \cdot \mathrm{g}_{2}=$ somatório das observações em que $\mathrm{T}$ e $\mathrm{G}$ apresentam os níveis

$$
\mathrm{t}_{+}(2 \%) \text { e } \mathrm{g}_{+}(\mathrm{G})
$$

$\mathrm{t}_{1} \cdot \mathrm{g}_{2}=$ somatório das observações em que o fator $\mathrm{G}$ apresenta o nível

$\mathrm{g}_{+}(\mathrm{G})$ e o fator T apresenta o nível t. $(1 \%)$

$\mathrm{t}_{2} \cdot \mathrm{g}_{1}=$ somatório das observações em que o fator $\mathrm{T}$ apresenta o nível

$t_{+}(2 \%)$ e o fator $G$ apresenta o nível $g_{-}(F)$

$\mathrm{t}_{1} \cdot \mathrm{g}_{1}=$ somatório das observações em que os fatores $\mathrm{T}$ e $\mathrm{G}$ apresentam os níveis t $\mathrm{C}_{-}(1 \%)$ e g. (F)

$$
(\mathrm{t} \cdot \mathrm{g})^{\prime \prime}=(-1 .-1)^{2}+(-1 .+1)^{2}+(+1 .-1)^{2}+(+1 .+1)^{2}=4
$$




\subsection{2 - Testes de Significância}

É mediante utilização de testes de significância que se aceita um determinado fator como responsável pelas variações nas respostas de um experimento. Considera-se, neste trabalho, o teste F de Snedecor que compara os valores de quadrados médios ou variâncias $(\mathrm{QM})$ segundo a expressão:

$$
\mathrm{F}=\frac{\mathrm{QM}_{\text {tratamento }}}{\mathrm{QM}_{\text {residuo }}}
$$

Os quadrados médios dos fatores e interações são obtidos a partir das somas de quadrados (SQ) e dos graus de liberdade (GL), segundo a expressão:

$$
\mathrm{QM}=\frac{\mathrm{SQ}}{\mathrm{GL}}
$$

As Tabelas 45, 46 e 47 apresentam a análise de variância dos resultados dos ensaios de módulo de resiliência (MR), resistência à tração (RT) e deformação permanente nas trilhas de roda.

TABELA 45 - Experimento fatorial: análise de variância para MR.

\begin{tabular}{lcccc}
\hline Fatores e Interações & $\begin{array}{c}\text { Soma dos } \\
\text { Quadrados }\end{array}$ & $\begin{array}{c}\text { Graus de } \\
\text { Liberdade }\end{array}$ & $\begin{array}{c}\text { Quadrado } \\
\text { Médio }\end{array}$ & Teste F \\
\hline Teor de Borracha (T) & 1113861 & 1 & 1113861 & $78,47^{*}$ \\
Granulometria da Borracha (G) & 903105 & 1 & 903105 & $63,62^{*}$ \\
Teor x Granulometria (TG) & 18723 & 1 & 18723 & 1,32 \\
\hline Resíduo & 113558 & 8 & 14195 & \\
\hline Total & 2161106 & 11 & & \\
\hline
\end{tabular}

\footnotetext{
${ }^{*}$ Significância de 5\%
} 
TABELA 46 - Experimento fatorial: análise de variância para RT.

\begin{tabular}{lcccc}
\hline Fatores e Interações & $\begin{array}{c}\text { Soma dos } \\
\text { Quadrados }\end{array}$ & $\begin{array}{c}\text { Graus de } \\
\text { Liberdade }\end{array}$ & $\begin{array}{c}\text { Quadrado } \\
\text { Médio }\end{array}$ & Teste F \\
\hline Teor de Borracha (T) & 0,044 & 1 & 0,044 & $21,21^{*}$ \\
Granulometria da Borracha (G) & 0,003 & 1 & 0,003 & 1,44 \\
Teor x Granulometria (TG) & 0,000 & 1 & 0,000 & 0,00 \\
\hline Resíduo & 0,017 & 8 & 0,002 & \\
\hline Total & 0,065 & 11 & & \\
\hline
\end{tabular}

${ }^{*}$ Significância de 5\%

TABELA 47 - Experimento Fatorial: análise de variância para afundamento em trilha de roda.

\begin{tabular}{lcccc}
\hline Fatores e Interações & $\begin{array}{c}\text { Soma dos } \\
\text { Quadrados }\end{array}$ & $\begin{array}{c}\text { Graus de } \\
\text { Liberdade }\end{array}$ & $\begin{array}{c}\text { Quadrado } \\
\text { Médio }\end{array}$ & Teste F \\
\hline Teor de Borracha (T) & 24,01 & 1 & 24,01 & $11,68^{*}$ \\
Granulometria da Borracha (G) & 43,62 & 1 & 43,62 & $21,21^{*}$ \\
Teor x Granulometria (TG) & 13,06 & 1 & 13,06 & 6,35 \\
\hline Resíduo & 8,23 & 4 & 2,06 & \\
\hline Total & 96,36 & 7 & & \\
\hline
\end{tabular}

${ }^{*}$ Significância de 5\%

\subsection{3 - Construção dos Modelos Matemáticos}

A análise de variância de um experimento fatorial permite não só a identificação dos fatores estatisticamente significativos mas também o desenvolvimento de modelos matemáticos, que relacionam os fatores significativos (variáveis independentes) com a resposta do sistema (variável dependente). 
Com base na soma dos quadrados (SQ) de cada fator ou interação, pode-se quantificar a contribuição de cada termo e também obter seus efeitos de ordem $\mathrm{n}-1$, onde $\mathrm{n}$ é o número de níveis do fator em questão. Deste modo, fatores com três níveis poderão contribuir com até dois termos para a equação de regressão, um linear e outro quadrático. Um modelo matemático, considerando os fatores granulometria da borracha $(\mathrm{G})$ e teor de borracha $(\mathrm{T})$, ambos com dois níveis, pode ser escrito da seguinte forma:

$$
\mathrm{Y}=\alpha_{0}+\alpha_{\mathrm{T}} \cdot \mathrm{P}(\mathrm{T})+\alpha_{\mathrm{G}} \cdot \mathrm{P}(\mathrm{G})+\alpha_{\mathrm{TG}} \cdot \mathrm{P}(\mathrm{T}) \cdot \mathrm{P}(\mathrm{G})
$$

onde:

$$
\begin{aligned}
& \begin{array}{l}
\mathrm{Y}=\text { variável dependente } \\
\mathrm{T} \text { e } \mathrm{G}=\text { representam os fatores considerados. }
\end{array} \\
& \begin{array}{l}
\alpha_{0}=\frac{\sum \mathrm{x}}{\mathrm{n}} \\
\quad \sum \mathrm{X}=\text { somatório de todas as observações } \\
\mathrm{n}=\text { número de observações }
\end{array} \\
& \alpha_{\mathrm{T}}=\text { coeficiente correspondente ao fator } \mathrm{T} \\
& \alpha_{\mathrm{G}}=\text { coeficiente correspondente ao fator } \mathrm{G} \\
& \alpha_{\mathrm{TG}}=\text { coeficiente correspondente à interação TG } \\
& \mathrm{P}(\mathrm{T})=+1(2 \%) \text { ou }-1(1 \%) \\
& \mathrm{P}(\mathrm{G})=+1(\mathrm{G}) \text { ou }-1(\mathrm{~F})
\end{aligned}
$$

O modelo matemático pode ser usado para calcular a resposta esperada para cada uma das condições de teste. Se o modelo contém todos os termos necessários para prever a resposta adequadamente, a diferença entre os valores estimados e os dados (respostas dos ensaios) deve apresentar o seguinte comportamento: 
- deve ser centrado em zero;

- deve tender a uma distribuição Normal;

- não deve variar em função da resposta prevista;

- não deve haver correlação com as variáveis independentes (os resíduos do modelo devem apresentar as mesmas propriedades do erro experimental).

Alguns dos testes que podem ser aplicados para verificar a validade dessas suposições são:

- Gráfico de Probabilidade Normal dos resíduos;

- Gráfico dos resíduos versus seqüência de realização dos testes;

- Gráfico dos resíduos versus resposta prevista;

- Gráfico dos resíduos versus variáveis independentes.

Um experimento fatorial também permite que, a partir das somas de quadrados dos fatores e interações significativos (aqueles que entram na equação de regressão), o cálculo do coeficiente de determinação $\left(\mathrm{R}^{2}\right)$ do modelo, segundo a expressão:

$$
\mathrm{R}^{2}=\frac{\mathrm{SQ}_{\text {modelo }}}{\mathrm{SQ}_{\text {total }}}=\frac{\Sigma \mathrm{SQ}_{\mathrm{i}}}{\mathrm{SQ}_{\text {total }}}
$$

onde $\mathrm{SQ}_{\mathrm{i}}$ indica a soma de quadrados dos fatores presentes na equação de regressão.

As equações (modelos de regressão) considerando-se os fatores que se mostraram significativos na análise de variância efetuada (Tabelas 45, 46 e 47) e os respectivos coeficientes de determinação $\left(R^{2}\right)$, juntamente com os gráficos de verificação da adequabilidade dos modelos, são apresentados a seguir: 


\section{a) Módulo de Resiliência}

$\mathrm{Y}=2173,83-304,67(\mathrm{~T})-274,33(\mathrm{G})$

$\mathrm{R}^{2}=0,93$

\section{b) Resistência à Tração}

$\mathrm{Y}=1,07-0,06(\mathrm{~T})$

$\mathrm{R}^{2}=0,68$

\section{c) Deformação Permanente}

$$
\begin{aligned}
& \mathrm{Y}=10,81+1,73(\mathrm{~T})+2,34(\mathrm{G}) \\
& \mathrm{R}^{2}=0,70
\end{aligned}
$$

As Figuras 45, 48 e 50 apresentam os gráficos de resíduos versus respostas estimadas e as Figuras 46, 47, 49, 51 e 52 apresentam os gráficos de resíduos versus variáveis independentes.

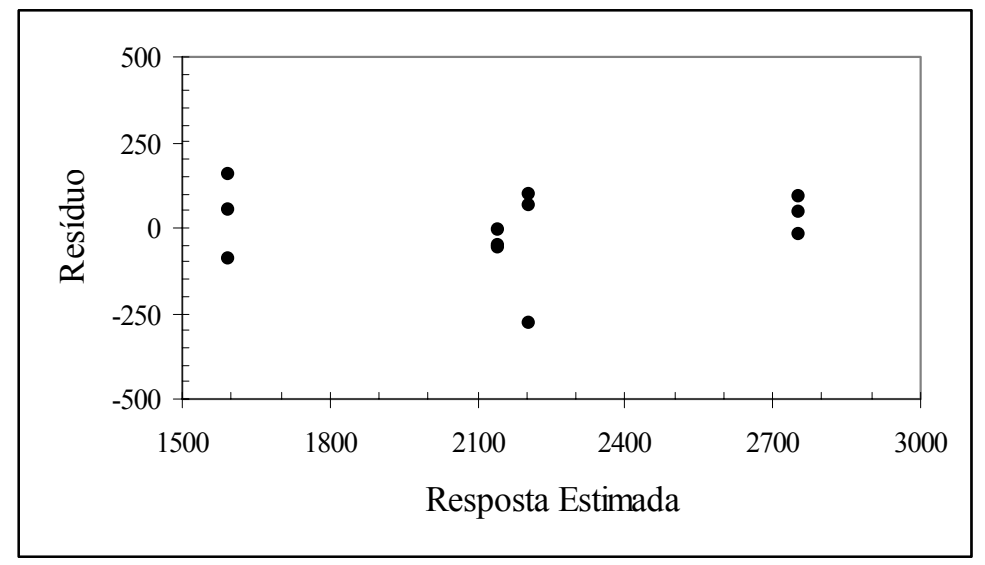

FIGURA 45 - Resíduo versus resposta estimada para MR. 


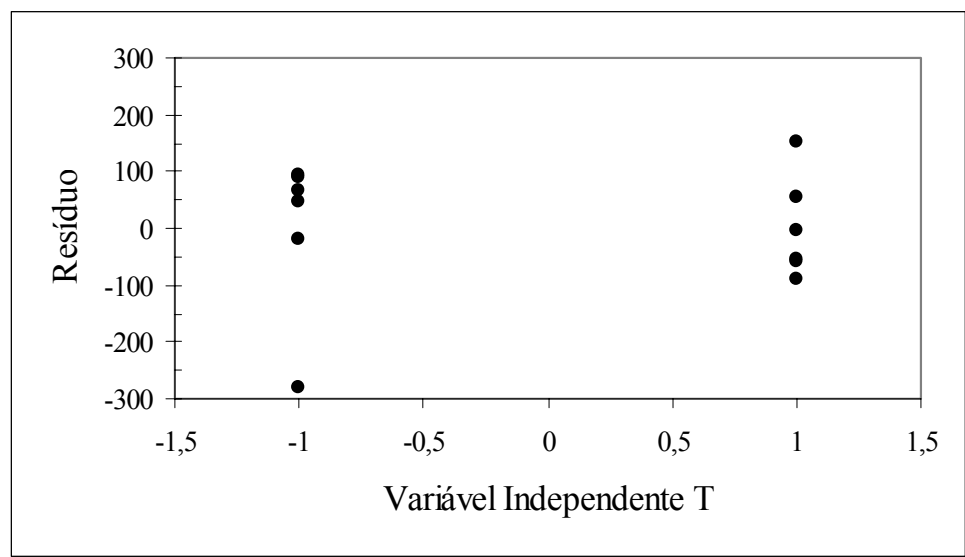

FIGURA 46 - MR: resíduo versus variável independente T (teor de borracha)

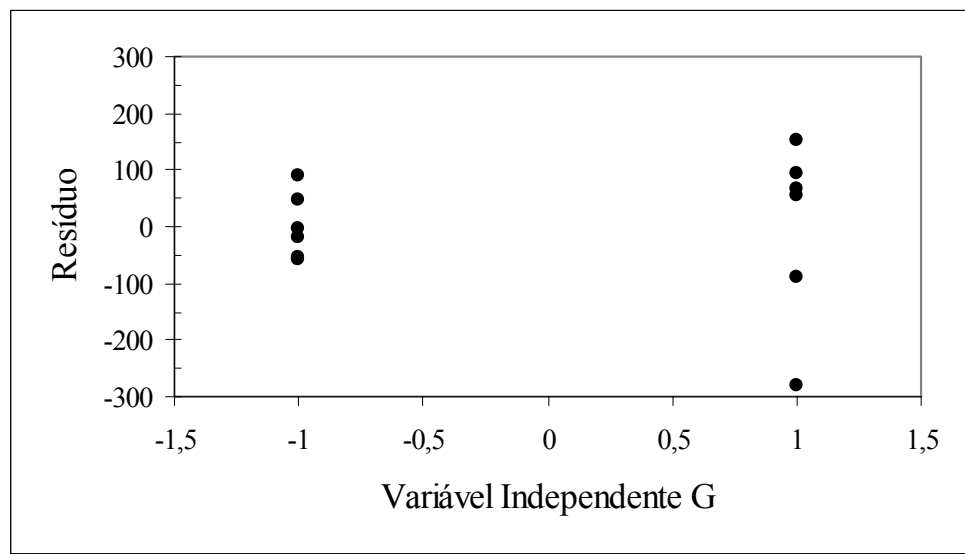

FIGURA 47 - MR: resíduo versus variável independente G (granulometria da borracha).

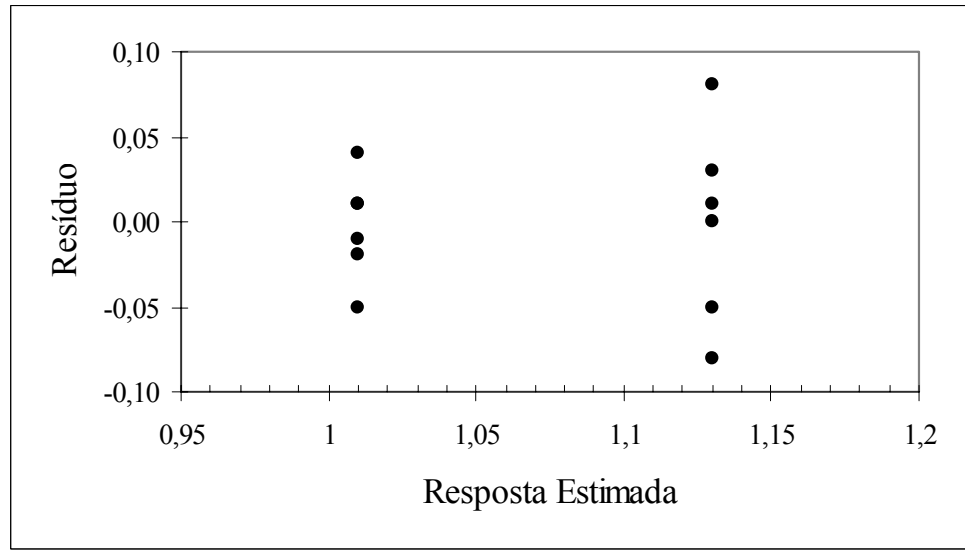

FIGURA 48 - Resíduo versus resposta estimada para RT. 


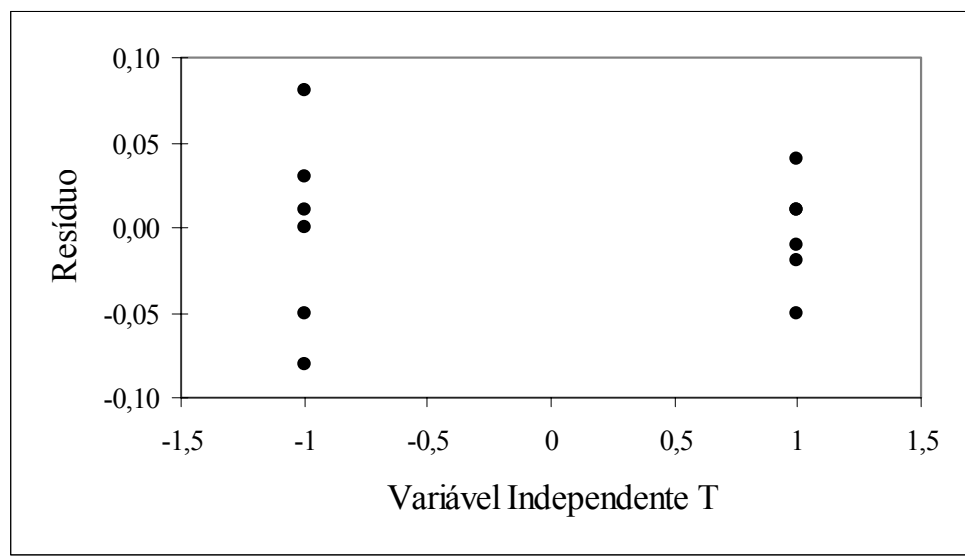

FIGURA 49 - RT: resíduo versus variável independente T (teor de borracha).

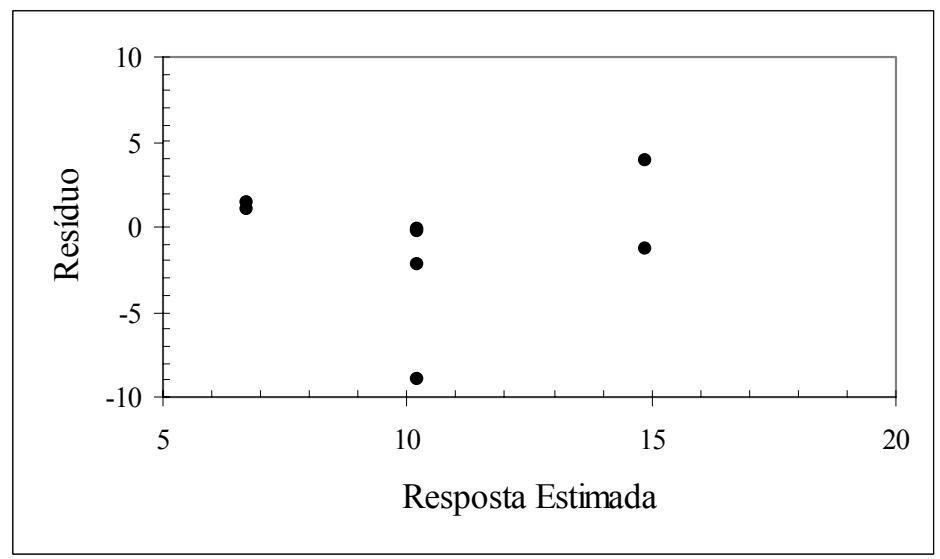

FIGURA 50 - Resíduo versus resposta estimada para deformação permanente em trilha de roda.

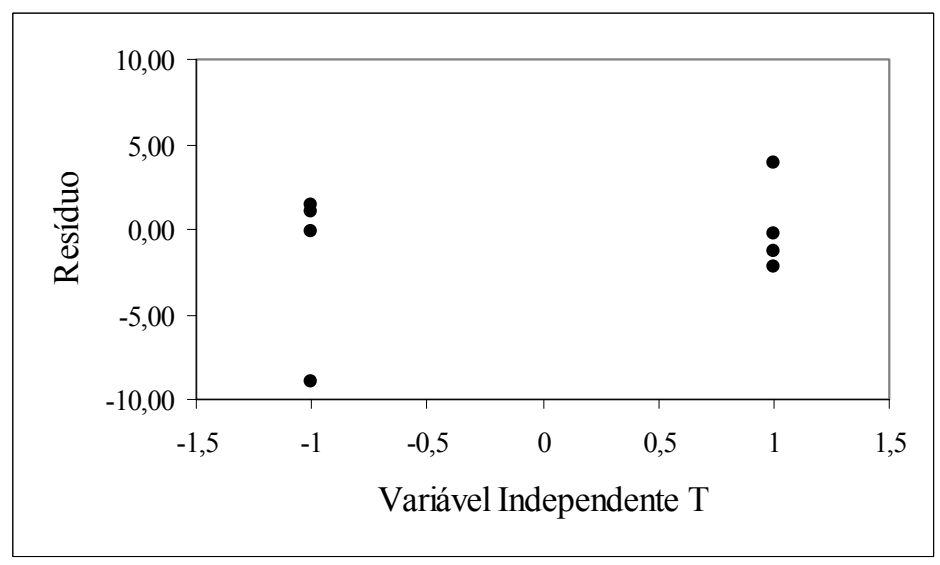

FIGURA 51 - Deformação permanente: resíduo versus variável independente $\mathrm{T}$ (teor de borracha) 


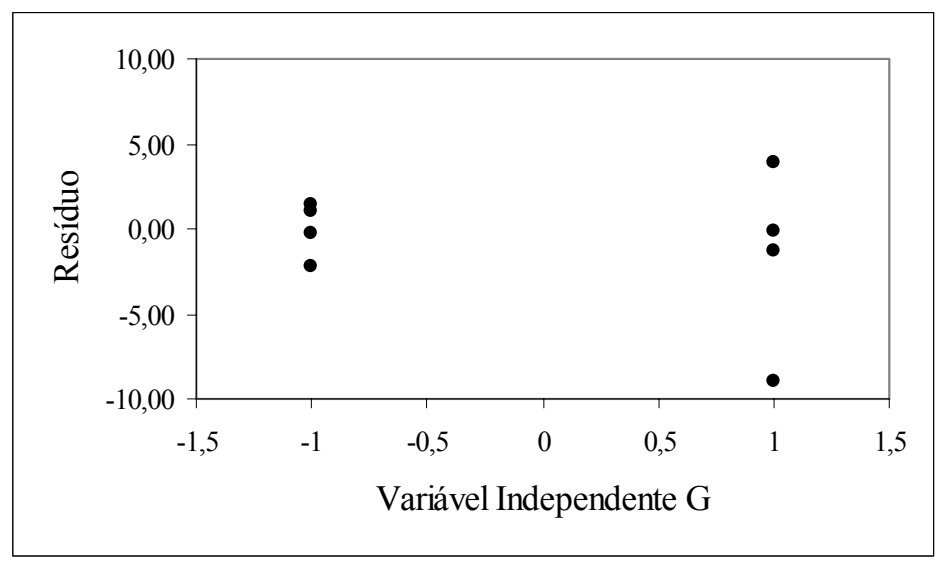

FIGURA 52 - Deformação permanente: resíduo versus variável independente G (granulometria da borracha).

A análise dos gráficos (Figuras 45 a 52) não indica nenhum comportamento marcadamente característico de não aleatoriedade dos resíduos, o que leva à aceitação dos modelos propostos como sendo aproximações adequadas da variação da resposta em função dos fatores de controle.

\subsection{4 - Análise dos Resultados}

As Figuras 53, 54 e 55, obtidas dos modelos matemáticos desenvolvidos no item anterior, apresentam, respectivamente, os efeitos do teor e da granulometria da borracha sobre os valores de módulo de resiliência, resistência à tração e deformação permanente em trilha de roda.

As linhas tracejadas representam o prolongamento das funções estatísticas até os pontos utilizados para controle, correspondentes aos resultados obtidos nos ensaios. 


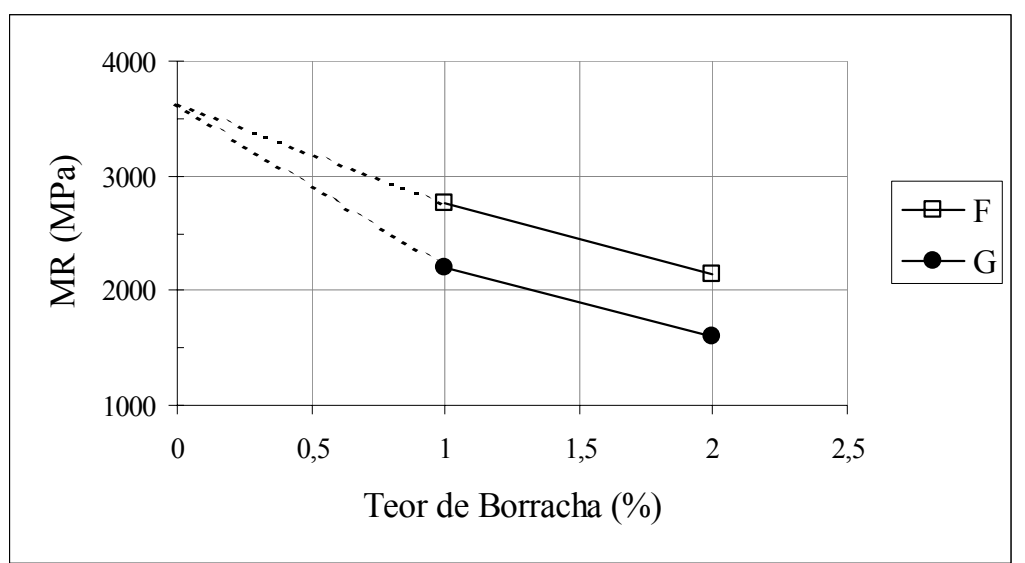

FIGURA 53 - Efeito do teor e granulometria da borracha no módulo de resiliência.

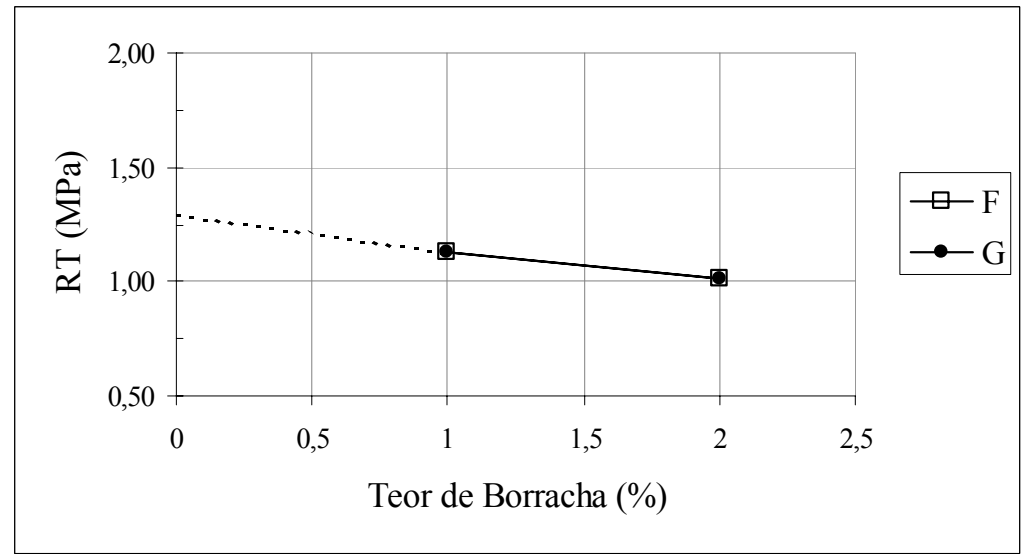

FIGURA 54 - Efeito do teor e granulometria da borracha na resistência à tração.

Os fatores granulometria de borracha e quantidade de borracha influenciam os resultados de módulo de resiliência nas misturas modificadas, conforme indicado pelo elevado coeficiente de correlação $\left(\mathrm{R}^{2}=0,93\right)$. $\mathrm{O}$ aumento do teor e do tamanho das partículas de borracha implica na diminuição do MR.

A Figura 54 mostra que apenas o fator teor de borracha influi nos resultados de resistência à tração. $\mathrm{O}$ aumento do teor de borracha implica na diminuição da RT. Entretanto, é importante observar o valor relativamente baixo do coeficiente de correlação, indicando que talvez o teor não seja o único fator 
que exerce influência no valor de RT. O modelo matemático apresentado consegue captar $68 \%$ da variabilidade dos dados, o que salienta a necessidade de inclusão de fatores e níveis adicionais no planejamento fatorial.

Pode-se observar que o MR cai significativamente com uma pequena adição de borracha, mas não proporcional à redução de RT, o que sugere, em princípio, uma maior flexibilidade e resistência à fadiga das misturas modificadas em relação à mistura de controle.

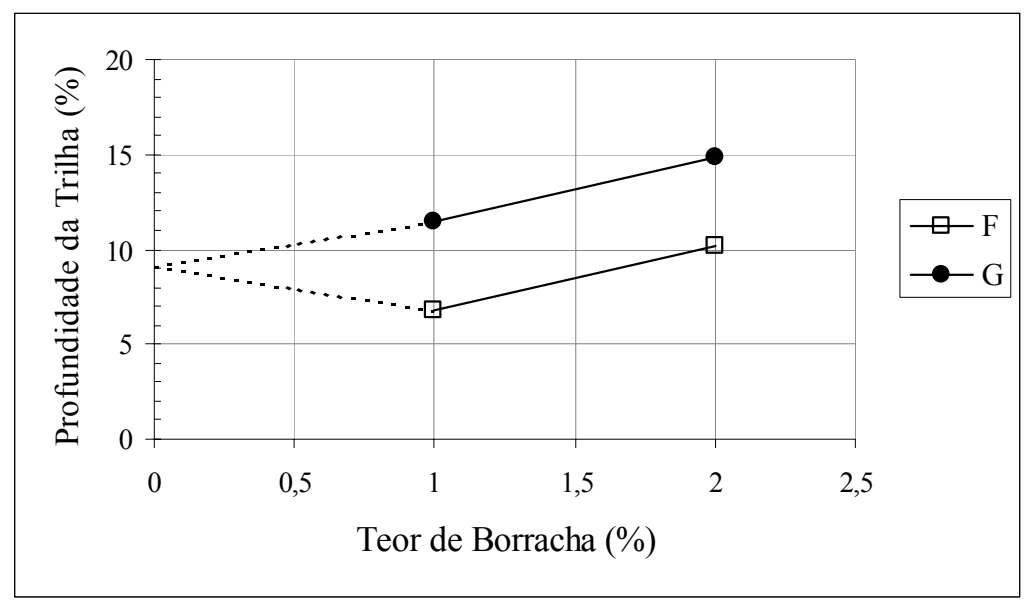

FIGURA 55 - Efeito do teor e granulometria da borracha no afundamento em trilha de roda.

Os fatores granulometria e teor de borracha influenciam na capacidade das misturas em resistir ao acúmulo de deformação permanente nas trilhas de roda. O desempenho melhora na medida em que são adicionadas partículas mais finas e em menores teores.

O coeficiente de correlação mostra que estes fatores contribuem com $70 \%$ da resposta do modelo desenvolvido, o que salienta a necessidade da inclusão de outras variáveis no planejamento fatorial. 


\section{7 - Conclusões e Sugestões Para TRABALHOS FUTUROS}

Face às questões discutidas neste trabalho, são apresentadas considerações finais relacionadas à gestão dos resíduos de pneus no Brasil e, principalmente, aos aspectos técnicos relacionados à utilização de borracha reciclada substituindo parte dos agregados pétreos em misturas asfálticas.

Realizou-se um levantamento da quantidade e formas de disposição dos pneus inservíveis em 12 cidades distribuídas por todas as regiões do estado de São Paulo. Com base nos resultados obtidos, pode-se estimar em 5 milhões o número de pneus descartados anualmente no estado de São Paulo, o que corresponde a uma geração média de 0,14 pneu/pessoa/ano. A análise das respostas também evidencia a falta de controle desses resíduos por parte das administrações municipais.

Outra estimativa, considerando a frota nacional, resulta em mais de 44 milhões de pneus descartados por ano, cerca de 0,26 pneu/pessoa/ano, número relativamente baixo quando comparado com valores médios da Europa e EUA, mas suficiente para ressaltar a gravidade do problema, pois a maioria dos pneus inservíveis é disposta de maneira ambientalmente inadequada. 
A pesquisa mostrou que algumas cidades estão empenhadas em encontrar alternativas de utilização para os pneus estocados, como por exemplo para controle de erosão, drenagem de líquidos percolados no aterro sanitário e, também, atividades de reabilitação e construção de pavimentos com incorporação de borracha de pneus.

A partir de janeiro de 2002, a coleta e a destinação final adequada dos pneus inservíveis se tornou uma imposição legal a ser seguida pelos fabricantes e importadores. A Resolução № 258 do Conselho Nacional do Meio Ambiente (CONAMA) representa um importante avanço na legislação ambiental, mas é fundamental que sejam pesquisadas alternativas eficientes para reaproveitamento dos pneus.

Os altos investimentos e a falta de financiamentos especiais para a indústria de reciclagem, somados à carga tributária incidente nos produtos fabricados com matéria-prima reciclada, estão entre os principais obstáculos ao desenvolvimento de uma indústria de reciclagem de pneus no Brasil. Nesse sentido, uma das principais inovações da Política Nacional de Resíduos (projeto de lei 3029/97), em tramitação no Congresso Nacional, será a criação da figura de empresa exclusivamente recicladora, que contará com isenção de impostos, o que poderá representar uma importante forma de incentivo à utilização de materiais reciclados na fabricação de novos produtos ou em novas aplicações.

A reciclagem de pneus envolve um ciclo que compreende a coleta, transporte, trituração e separação de seus componentes (borracha, aço e lona), transformando sucatas em matérias-primas que serão direcionadas ao mercado. Quanto menor a granulometria maior o custo envolvido e esse custo pode inviabilizar o desenvolvimento de alguns mercados potenciais. Neste ponto, é fundamental a parceria entre universidades e empresas, buscando-se 
analisar as oportunidades de mercado e o desenvolvimento de tecnologias adaptadas à nossa realidade e que possibilitem a utilização da borracha reciclada em larga escala.

Os resultados dos ensaios de solubilização realizados nas amostras de borracha apresentaram teores de metais (zinco e manganês) no extrato solubilizado superiores aos padrões estabelecidos pela NBR 10004, classificando esse resíduo como sendo Classe II (não inerte). Entretanto, quando foram utilizadas amostras onde a borracha foi incorporada à mistura asfáltica, estas não apresentaram nenhum de seus constituintes solubilizados a concentrações superiores aos limites máximos, mostrando, dessa forma, que a incorporação da borracha na mistura asfáltica foi eficiente para sua inertização.

Os resultados mostram que a trituração de pneus usados, com o objetivo de redução de volume anteriormente à sua disposição em aterros sanitários, não é uma medida totalmente adequada do ponto de vista ambiental. Por outro lado, a incorporação da borracha como parte dos agregados em misturas asfálticas foi eficiente na estabilização dos aditivos altamente tóxicos utilizados na fabricação dos pneus, não apresentando riscos potenciais ao meio ambiente.

Nas misturas preparadas com borracha, verificou-se que o tempo de digestão (interação asfalto-borracha durante o tempo de preparação e transporte da mistura) é um fator importante, que deve ser considerado no projeto de misturas modificadas pelo processo seco.

Foram analisadas a mistura de controle, uma mistura com 2\% de borracha grossa e uma mistura com $2 \%$ de borracha fina. Parte de cada uma das amostras foi compactada imediatamente e a outra parte foi submetida ao envelhecimento em estufa (por duas horas, a $150^{\circ} \mathrm{C}$ ) anteriormente à compactação. Verificou-se que a mistura com $2 \%$ de borracha grossa 
apresentou aumento no valor de resistência à tração após o envelhecimento, o que ressalta a importância da consideração do tempo de digestão no projeto de misturas modificadas pelo processo seco, principalmente quando são incorporadas partículas maiores de borracha.

As misturas modificadas com adição de borracha dosadas para um volume de vazios de $4 \%$ apresentaram deformação permanente excessiva e precoce, indicando teores de ligante elevados, fato também constatado no ensaio Marshall, em razão dos elevados valores de fluência. Outra evidência de que o valor de volume de vazios não deve ser usado como critério na determinação do teor ótimo de ligante para essas misturas foi dada pelos resultados dentro das especificações de deformação permanente obtidos com teores de ligante iguais ao da mistura de controle.

Na programação fatorial dos experimentos foram considerados os fatores teor e granulometria de borracha, por serem estes considerados os mais significativos. O planejamento fatorial possibilitou o desenvolvimento de modelos matemáticos para as diferentes propriedades consideradas. O modelo desenvolvido para o módulo de resiliência representa satisfatoriamente os efeitos dos fatores sobre o ensaio, com elevado coeficiente de determinação. Os modelos desenvolvidos para resistência à tração e deformação permanente apresentaram valores menores de coeficiente de determinação, o que salienta a necessidade de consideração de fatores e níveis adicionais.

Os resultados dos ensaios de trilha de roda indicam que a incorporação de borracha na granulometria fina proporciona efeito benéfico, melhorando o desempenho em termos de resistência à deformação permanente quando comparada à mistura de controle. A incorporação de $1 \%$ de borracha na granulometria grossa não comprometeu o desempenho das misturas. 
As misturas modificadas com borracha apresentaram menores valores de módulo de resiliência e de resistência à tração quando comparadas à mistura de controle. O módulo de resiliência cai significativamente com uma pequena adição de borracha, mas não proporcional à redução de resistência à tração, sugerindo, em princípio, uma maior flexibilidade e resistência à fadiga das misturas modificadas em relação à mistura de controle.

Os valores de módulo de resiliência das misturas modificadas diminuíram com o aumento do tamanho e da quantidade de borracha adicionada. Os valores de resistência à tração diminuíram com o aumento do teor de borracha. Os resultados dos ensaios de resistência à tração não mostraram diferença significativa de comportamento em função da granulometria da borracha.

O equacionamento dos problemas ambientais relatados depende, fundamentalmente, da organização das empresas fabricantes de pneus, das empresas distribuidoras, dos poderes públicos federal, estadual e municipal e dos consumidores para a adoção de soluções visando o recolhimento e armazenamento dos pneus em condições adequadas, procurando-se um mercado para a sua reutilização e reciclagem.

Este trabalho mostrou que a incorporação de borracha triturada de pneus em pavimentação asfáltica pode ser uma das alternativas tecnicamente viáveis de reciclagem para esse tipo de resíduo. A incorporação em pavimentos asfálticos também se destaca pelo potencial de consumo de pneus inservíveis: dos cerca de 1,7 milhões de quilômetros da malha viária existente no Brasil, menos de 10\% (aproximadamente 160 mil quilômetros) são revestidos por pavimentos asfálticos. 
A borracha obtida da trituração de pneus deve ser considerada como um bem valioso, cuja utilização vem se expandindo em mercados diversificados. Sua utilização em pavimentos não pretende transformar as rodovias em "aterros lineares". Pelo contrário, os ensaios de solubilização e lixiviação mostraram que a incorporação da borracha na mistura asfáltica foi eficiente na sua inertização. Os resultados apresentados indicam que a inclusão de borracha de pneus nas misturas asfálticas não compromete seu desempenho, ao contrário, pode melhorar algumas propriedades mecânicas, o que torna promissor o seu uso como agregado.

No Brasil, as pesquisas sobre reutilização de pneus em obras de pavimentação estão apenas começando. Há muito a se conhecer sobre o processo seco de incorporação de borracha em misturas asfálticas, incluindo critérios de dosagem, ensaios e parâmetros para avaliação em laboratório, técnicas construtivas, desempenho de trechos experimentais e possibilidade de reciclagem.

Baseado nos resultados obtidos e nas considerações feitas durante a exposição deste trabalho, são feitas as seguintes sugestões para trabalhos futuros:

- Consideração de outros fatores e níveis no planejamento fatorial, visando avaliar a possibilidade de utilização de uma mistura modificada com borracha para finalidades estruturais e funcionais distintas das de uma mistura asfáltica densa;

- Avaliação da adição de raspas de borracha, matéria-prima gerada em grande volume pelas empresas de recauchutagem, mas que apresenta forma preponderantemente lamelar;

- Avaliação da inserção de diferentes teores de borracha diretamente na curva granulométrica, sem exclusão de agregados; 
- Análise do comportamento das misturas com a variação do teor de ligante e, portanto, do teor de vazios, buscando-se encontrar novos parâmetros de dosagem e avaliação das misturas modificadas;

- Estudos complementares, buscando-se variar o tempo e a temperatura durante o envelhecimento de curto prazo, além de um estudo para analisar o desempenho das misturas em longo prazo;

- Realização de ensaios para a determinação da vida de fadiga em misturas virgens e envelhecidas;

- Realização de ensaios de creep dinâmico, mais simples que os equipamentos simuladores de tráfego em laboratório tipo LCPC, para avaliação da resistência à deformação permanente;

- Execução de trechos experimentais, com o controle dos principais fatores intervenientes, visando a confirmação da potencialidade das misturas asfálticas modificadas com adição de borracha e a verificação da possibilidade de sua reciclagem. 


\section{REFERÊNCIAS BIBLIOGRÁFICAS}

AASHTO (1989). T-283 - Resistance of Compacted Bituminous Mixture to Moisture Induced Damage. American Association of State Highway Transportation Officials.

AASHTO (1993). T-166 - Bulk Specific Gravity of Compacted Bituminous Mixtures Using Saturated Surface-Dry Specimens. American Association of State Highway Transportation Officials.

ABIP (1996). Guerra dos Pneus: cartel das multinacionais versus importadores de pneus "meia-vida". Publicação da Associação Brasileira de Importadores de Pneus. Pinhais.

ABNT (1987a). NBR 10004 - Resíduos Sólidos - Classificação. Associação Brasileira de Normas Técnicas, Rio de Janeiro. 63p.

ABNT (1987b). NBR 10005 - Lixiviação de Resíduos. Associação Brasileira de Normas Técnicas, Rio de Janeiro. 10p.

ABNT (1987c). NBR 10006 - Solubilização de Resíduos. Associação Brasileira de Normas Técnicas, Rio de Janeiro. 2p.

ABNT (1993). NBR 12891/93 - Dosagem de Misturas Betuminosas pelo Método Marshall. Associação Brasileira de Normas Técnicas, Rio de Janeiro.

AFNOR (1991a). Déformation Permanente des Mélanges Hydrocarbonés Partie 1: Essai d'orniérage. NF P 98-253-1. Association Française de Normalisation, Paris, França.

AFNOR (1991b). Préparation des Mélanges Hydrocarbonés - Partie 2: Compactage des plaques. NF P 98-250-2. Association Française de Normalisation, Paris, França.

AMARI, T.; THEMELIS, N. J.; WERNICK, I. K. (1999). Resource Recovery from Used Rubber Tires. Resources Policy. Volume 25 (3), p.179-188.

BAKER, R. F.; CONNOLLY, E. (1995). Mix Designs and Air Quality Emissions Tests of Crumb Rubber Modified Asphalt Concrete. Transportation Research Record 1515. TRB. National Research Council. Washington, D.C., p.18-27.

BALLIÉ, M.; ROFFÉ, J. (2000). Low-Noise Asphalt Concrete for Wearing Course Using Crumb Rubber Powder from Used Tyres. Proceedings of the Asphalt Rubber 2000 Conference. Portugal, p.485-494. 
BARBOSA, A. (2002). Petrobrás transforma pneu velho e xisto em óleo combustível. O Estado de São Paulo - Agência Estado, São Paulo, 24 mar. BERTOLlO, S. A. M. (1997). Considerações sobre a Gerência de Pavimentos Urbanos em Nível de Rede. São Carlos. 194p. Dissertação (Mestrado) - Escola de Engenharia de São Carlos, Universidade de São Paulo.

BERTOLLO, S. A. M.; FERNANDES JR., J. L.; VILLAVERDE, R. B.; MIGOTTO FILHO, D. (2000). Pavimentação asfáltica: uma alternativa para a reutilização de pneus usados. Revista Limpeza Pública, n. 54. Associação Brasileira de Limpeza Pública - ABLP, p.23-30, Jan.

BROWN, E. R.; KANDHAL, P. S.; ZHANG, J. (2001). Performance Testing for Hot Mix Asphalt. National Center for Asphalt Technology. NCAT Report No. 01-05. Nov.

BUCHANAN, M. S. (2000). Evaluation of the Effect of Flat and Elongated Particles on the Performance of Hot Mix Asphalt Mixtures. National Center for Asphalt Technology. NCAT Report No. 2000-03. May.

CARLSON, D. D.; ZHU, H. (1999). Asphalt-Rubber, An Anchor to Crumb Rubber Markets. Third Joint UNCTAD/IRSG Workshop on Rubber and the Environment. International Rubber Forum. Veracruz, Mexico. Oct.

CE (2000). A UE e a Gestão dos Resíduos. Comissão Européia. Luxemburgo: Serviço das Publicações Oficiais das Comunidades Européias. 18p.

CNT (2001). Pesquisa Rodoviária CNT. Confederação Nacional dos Transportes. http://www.cnt.org.br (03 Dez.).

COCHRAN, W. G.; COX, G. M. (1962). Experimental Designs. Second Edition. John Wiley \& Sons. New York.

COELHO, V. (1996). Contribuição ao Estudo das Deformações Permanentes, nas Condições do Brasil, em Camadas de Concreto Asfáltico de Pavimentação. São Carlos. 281p. Tese (Doutorado) - Escola de Engenharia de São Carlos, Universidade de São Paulo.

COOLEY JR., L. A. (1999). Permeability of Superpave Mixtures: Evaluation of Field Permeameters. National Center for Asphalt Technology. NCAT Report No. 99-01. Feb.

COOLEY JR., L. A.; KANDHAL, P. S.; BUCHANAN, M. S.; FEE, F.; EPPS, A. (2000). Loaded Wheel Testers in the United States: State of the Practice. National Center for Asphalt Technology. NCAT Report No. 2000-4. July.

COSTA, J. T.; DALMAS, J. C.; GIROLDO, A. C.; XAVIER, M. S. (2000). O descarte de pneus usados em Londrina. Revista Limpeza Pública, n. 54. Associação Brasileira de Limpeza Pública - ABLP, p.5-11, Jan.

CROSS, S. A.; BROWN, E. R. (1992). Selection of Aggregate Properties to Minimize Rutting of Heavy Duty Pavements. Effects of Aggregates and Mineral Fillers on Aphalt Misture Performance. ASTM STP 1147. Richard C. Meininger, Ed., American Society for Testing and Materials, Philadelphia, p.45-67. 
DER-SP (1991). Camada de Rolamento de Concreto Asfáltico e Camada Intermediária ("binder") Asfáltica Usinada a Quente. In: Manual de Normas, Pavimentação. São Paulo, Departamento de Estradas de Rodagem do Estado de São Paulo.

DNER (1994a). ME 133/94 - Misturas Betuminosas - determinação do módulo de resiliência. Departamento Nacional de Estradas de Rodagem, Rio de Janeiro.

DNER (1994b). ME 138/94 - Misturas Betuminosas - determinação da resistência à tração por compressão diametral. Departamento Nacional de Estradas de Rodagem, Rio de Janeiro.

DNER (1995). ME 43/95 - Misturas Betuminosas a Quente - Ensaio Marshall. Departamento Nacional de Estradas de Rodagem, Rio de Janeiro.

DNER (1997). Especificação de serviço DNER-ES 313/97, Pavimentação Concreto betuminoso - Norma Rodoviária. Departamento Nacional de Estradas de Rodagem, Rio de Janeiro.

EATON, R. A.; ROBERTS, R. J.; BLACKBURN, R. R. (1991). Use of Scrap Rubber in Asphalt Pavements Surfaces. Special Report 91-27. U.S. Army Corps of Engineers. Prepared by Strategic Highway Research Program. Dec., $14 \mathrm{p}$.

ENVIRONMENT AUSTRALIA (2001). A National Approach to Waste Tyres. Prepared for Environment Australia by Atech Group. Commonwealth Department of Environment. Australia, 180p. June.

EPA (1991). Summary of Markets for Scrap Tires. U.S. Environmental Protection Agency. EPA-530-SW-90-074B. Oct.

EPA (1999). State Scrap Tire Programs - A Quick Reference Guide: 1999 Update. U. S. Environmental Protection Agency. EPA-530-B-99-002.

EPA (2001). Information Sheet NO. 15 - Waste Tyres. Environment Protection Agency. Government of South Australia. 7p. Feb.

EPPS, J. A. (1994). NCHRP Synthesis of Highway Practice 108: Uses of Recycled Rubber Tires in Highways. TRB, National Research Council, Washington, D.C., 162p.

FERNANDES JR., J. L. (1994). Investigação dos Efeitos das Solicitações do Tráfego sobre o Desempenho de Pavimentos. São Carlos. 313p. Tese (Doutorado) - Escola de Engenharia de São Carlos, Universidade de São Paulo.

FHWA (1993). Crumb Rubber Modifier - Design Procedures and Construction Practices. Workshop Notes. U.S. Department of Transportation. Federal Highway Administration. Publication № ${ }^{\circ}$ FHWASA-93-011.

FHWA (1995). Background of Superpave Asphalt Mixture Design and Analysis. National Asphalt Training Center. Demonstration Project 101. U. S. Department of Transportation. Federal Highway Administration. Publication № ${ }^{\mathrm{o}}$. FHWA-AS-95-003. Feb. 159p. 
FIORI, J. (1998). Petrobrás tira óleo do pneu usado cooperando com o combate da dengue. Revista Limpeza Pública, n. 47. Associação Brasileira de Limpeza Pública - ABLP, p.3-5.

GALLEGO, J.; DEL VAL, M. A.; TOMÁS, R. (2000). A Spanish Experience with Asphalt Pavements Modified with Tire Rubber. Proceedings of the Asphalt Rubber 2000 Conference. Portugal, p.673-687.

GEIPOT (2001a). Frota Nacional de Veículos Automotores - número de veículos existentes - 1999. Anuário Estatístico dos Transportes. Empresa Brasileira de Planejamento de Transportes. Ministério dos Transportes. http://www.geipot.gov.br.

GEIPOT (2001b). Rede Rodoviária: extensão total das rodovias pavimentadas e não-pavimentadas - 1995-99. Anuário Estatístico dos Transportes. Empresa Brasileira de Planejamento de Transportes. Ministério dos Transportes. http://www.geipot.gov.br.

GIBRA, I. N. (1973). Probability and Statistical Inference for Scientists and Engineers. Prentice-Hall, Inc., Englewood Cliffs, New Jersey, 596p.

GOWDA, G. V.; HALL, K. D.; ELLIOTT, R. P. (1996). Arkansas Experience with Crumb Rubber Modified Mixes Using Marshall and Strategic Highway Research Program Level I Design Methods. Transportation Research Record 1530. TRB. National Research Council. Washington, D.C., p. 25-33.

HAFEZ, I. H.; WITCZAK, M. W. (1995). Comparison of Marshall and Superpave Level I Mix Design for Asphalt Mixes. Transportation Research Record 1492. TRB. National Research Council. Washington, D.C., p.161-175.

HARVEY, J.; TSAI, B. (1996). Effects of Asphalt Content and Air Void Content on Mix Fatigue and Stiffness. Transportation Research Record 1543. TRB. National Research Council. Washington, D.C., p.38-45.

HEITZMAN, M. (1992). Design and Construction of Asphalt Paving Materials with Crumb Rubber Modifier. Transportation Research Record 1339. TRB. National Research Council. Washington, D.C., p.1-8.

HICKS, R. G. (1991). NCHRP Synthesis of Highway Practice 175: Moisture Damage in Asphalt Concrete. TRB, National Research Council, Washington, D.C., 90p.

HINRICHSEN, J. A.; HEGGEN, J. (1996). Minimum Voids in Mineral Aggregate in Hot-Mix Asphalt Based on Gradation and Volumetric Properties. Transportation Research Record 1545. TRB. National Research Council. Washington, D.C., p.75-79.

HUBER, G. A. (1999). NCHRP Synthesis 274 - Methods to Achieve RutResistant Durable Pavements. National Cooperative Highway Research Program. Transportation Research Board, National Research Council, Washington, D.C. 
IBGE (1996). Contagem da População: 1996 - Estado de São Paulo. Instituto Brasileiro de Geografia e Estatística. http:/www.ibge.gov.br/ibge/ estatística/populacao/contagem/spcont96.shtm (10 Jun.).

IBGE (2001). Censo Demográfico 2000. Instituto Brasileiro de Geografia e Estatística. http://www.ibge.gov.br (10 Jun.).

ISHAI, I.; CRAUS, J. (1996). Effects of Some Aggregate and Filler Characteristics on Behavior and Durability of Asphalt Paving Mixtures. Transportation Research Record 1530. TRB. National Research Council. Washington, D.C., p.75-85.

ISTEA (1991). Intermodal Surface Transportation Efficiency Act. Public Law 102-240 - Dec.

KANDHAL, P.S.; CHAKRABORTY, S. (1996). Evaluation of Voids in the Mineral Aggregate for HMA Paving Mixtures. National Center for Asphalt Technology. NCAT Report No. 96-4. Mar.

KANDHAL, P.S.; CROSS, S. A. (1993). Effect of Aggregate Gradation on Measured Asphalt Content. National Center for Asphalt Technology. NCAT Report No. 93-1. Presented at Annual Meeting of the Transportation Research Board in Washington, D.C. Jan. 32p.

KANDHAL, P.S.; FOO, K. Y.; MALLICK, R. B. (1998a). A Critical Review of VAM Requirements in Superpave. National Center for Asphalt Technology. NCAT Report No. 98-1. Jan.

KANDHAL, P.S.; LYNN, C. Y.; PARKER, F. (1998b). Tests for Plastic Fines in Aggregates Related to Stripping in Asphalt Paving Mixtures. National Center for Asphalt Technology. NCAT Report No. 98-3. Mar.

KANDHAL, P.S.; PARKER, JR. F. (1998). NCHRP Report 405 - Aggregate Tests Related to Asphalt Concrete Performance in Pavements. National Cooperative Highway Research Program. Transportation Research Board, National Research Council, Washington, D.C., 92p.

KIM, Y. R.; KIM, N.; KHOSLA, N. P. (1992). Effects of Aggregate Type and Gradation on Fatigue and Permanent Deformation of Asphalt Concrete. Effects of Aggregates and Mineral Fillers on Aphalt Misture Performance. ASTM STP 1147. Richard C. Meininger, Ed., American Society for Testing and Materials, Philadelphia, p.311-328.

LIANG, R. Y.; LEE, S. (1996). Short-Term and Long-Term Aging Behavior of Rubber Modified Asphalt Paving Mixture. Transportation Research Record 1530. TRB. National Research Council. Washington, D.C., p. 1117.

LiTTle, D. N.; BUTTON, J. W.; YOSSEF, H. (1993). Development of Criteria to Evaluate Uniaxial Creep Data and Asphalt Concrete Permanent Deformation Potential. Transportation Research Record 1417. TRB. National Research Council. Washington, D.C., p.49-57.

MALLICK, R. B.; BUCHANAN, S.; BROWN, E. R.; HUNER, M. (1998). Evaluation of Superpave Gyratory Compaction of Hot Mix Asphalt. National Center for Asphalt Technology. NCAT Report No. 98-5. Jan. 
McQUILLEN JR., J. L.; TAKALLOU, H. B.; HICKS, R. G.; ESCH, D. (1988). Economic Analysis of Rubber-Modified Asphalt Mixes. Journal of Transportation Engineering. Vol. 114, nํㅜ 3, p.259-277, may.

MICHELIN (1999). Meio Ambiente. http://www.michelin.com.br/br/bra/ innov/p112.htm (13 Abr.).

MOTTA, L. M. G.; MEDINA, J.; SCALCO, R. C. (1993). O Projeto Estrutural de Pavimentos Flexíveis e a Dosagem de Misturas Asfálticas. Anais da $27^{a}$ Reunião Anual de Pavimentação, Vol. 1, ABPv, Teresina, p. 524-545.

NIKOULICHEV, M. (1999). Tire Recycling in Russia. Business Information Service for the Newly Independent States (BISNIS). Moscow. Feb.

OLIVEIRA, E. M.; RODRIGUES, A. B.; FARACHE, C. J. T.; SANTOS, G. E. (2000). Perspectivas de Soluções ao Problema dos Pneus Usados na Cidade do Natal. In: SIMPÓSIO LUSO-BRASILEIRO DE ENGENHARIA SANITÁRIA E AMBIENTAL. Porto Seguro, Bahia.

OLIVEIRA, P. M. F. (1997). Caracterização Mecânica de Misturas Betuminosas Preparadas com Asfalto Polímero. Niterói. $173 \mathrm{p}$. Dissertação (Mestrado) - Universidade Federal Fluminense.

OLIVER, J. W. H. (2000). Rutting and Fatigue Properties of Crumbed Rubber Hot Mix Asphalts. Proceedings of the Asphalt Rubber 2000 Conference. Portugal, p.221-239.

PAIVA, U. (1998). Rio Tietê transforma-se em depósito de pneus. O Estado de São Paulo, São Paulo, 23 abr. Cidades, p.12.

PAIVA, U. (1999). Impasse cria risco de grandes enchentes em SP. O Estado de São Paulo, São Paulo, 16 jan. Cidades, p.1.

PIRELLI (1998). Informações Técnicas. http://www.pirelli.com.br/pr/ pneumatici/ infotek/index.htm (08 Dez.).

REBALA, S. R.; ESTAKHRI, C. K. (1995). Laboratory Evaluation of Crumb Rubber Modified Mixtures Designed Using TxDOT Mixture Design Method. Transportation Research Record 1515. TRB. National Research Council. Washington, D.C., p.1-10.

RMA (2000). Scrap Tires - Facts and Figures. Rubber Manufacturers Association. http://rma.org/scraptires/facts_figures.html (20 Apr. 2001).

ROBERTS, F. L.; KANDHAL, P. S.; BROWN, E. R.; DUNNING, R. L. (1989). Investigation and Evaluation of Ground Tire Rubber in Hot Mix Asphalt. National Center for Asphalt Technology. NCAT Report No. 89-3.

ROCHA FILHO, M. F. (2001). Vai começar a reciclagem de pneus no País. $O$ Estado de São Paulo, São Paulo, 12 dez. Caderno Ciência.

RODGHER, S. F. (1996). Caracterização de Agregados Basálticos Através da Adsorção de Azul de Metileno. São Carlos. 143p. Dissertação (Mestrado) Escola de Engenharia de São Carlos, Universidade de São Paulo.

SATO, S. (1999) Fabricantes e importadores de pneus terão de destruir produtos usados. O Estado de São Paulo, São Paulo, 27 ago., p.18. 
SHARMA, V. K.; FORTUNA, F.; MINCARINI, M; BERILLO, M.; CORNACCHIA, G. (2000). Disposal of Waste Tyres for Energy Recovery and Safe Environment. Applied Energy 65, p.381-394.

SHRP (1999). SUPERPAVE 2000 - Improved Standards for a New Millennium. Strategic Highway Research Program. Technical Brief 17. Sep. 8p.

SIDDIQUI, Z.; TRETHEWEY, M. W.; ANDERSON, D. A. (1988). Variables Affecting Marshall Test Results. Transportation Research Record 1171. TRB. National Research Council. Washington, D.C., p.139-148.

SILVA, M. C. (1997). DAEE limpa o Tietê para controlar enchentes. $O$ Estado de São Paulo, São Paulo, 6 jan. Cidades, p.4.

SILVA, R. N. M.; ARAÚJO, C. R. S.; GARCEZ, R. M. (2000). Proteção de Encosta com Pneus - Saneamento Ambiental no Coroadinho em São Luís. In: SIMPÓSIO LUSO-BRASILEIRO DE ENGENHARIA SANITÁRIA E AMBIENTAL. Porto Seguro, Bahia.

SUCEN (2001). Casos de Dengue no Estado de São Paulo e Brasil, 1986 a 2000. Superintendência de Controle de Endemias. http://www.sucen.sp. gov.br/servicos_municipios/index.htm (20 Jul.).

TAKALLOU, H. B.; HICKS, R. G. (1988). Development of Improved Mix and Construction Guidelines for Rubber-Modified Asphalt Pavements. Transportation Research Record 1171. TRB. National Research Council. Washington, D.C., p.113-120.

TAKALlOU, H. B.; HICKS, R. G.; ESCH, D. C. (1986). Effect of Mix Ingredients on the Behavior of Rubber-Modified Asphalt Mixtures. Transportation Research Record 1096. TRB. National Research Council. Washington, D.C., p.68-80.

TAKAllOU, H. B.; SAINTON, A. (1992). Advances in Technology of Asphalt Paving Materials Containing Used Tire Rubber. Transportation Research Record 1339. TRB. National Research Council. Washington, D.C., p.23-29.

TAYEBALI, A. A.; MALPASS, G. A.; KHOSLA, N. P. (1998). Effect of Mineral Filler Type and Amount on Design and Performance of Asphalt Concrete Mixtures. Transportation Research Record 1609. TRB. National Research Council. Washington, D.C., p.36-43.

TNRCC (1999) Composition of a Tire. Texas Natural Resource Conservation Commission. Waste Tire Recycling Program. Austin, Texas.

TOMMASINI, G. (2000). Coleta e Reciclagem de Pneus no Brasil e no Exterior. In: SEMINÁRIO NACIONAL SOBRE REUSO/RECICLAGEM DE RESÍDUOS SÓLIDOS INDÚSTRIAIS. São Paulo. http://www.ambiente.sp.gov.br (03 Ago.).

TOMMASINI, G. (2001). Pneus: desafio da reciclagem. Revista Auto Esporte, n. 421, Ano 36. Editora Globo. 
TRANSAFETY (1997). Tires: A New Source for Culvert Pipe. Road Management Journal. August 11, 1997. http://www.usroads.com/journals/ rmj/9708/rm970805.htm (15 Nov.).

TROY, K.; SEBAALY, P. E.; EPPS, J. A. (1996). Evaluation Systems for Crumb Rubber Modified Binders and Mixtures. Transportation Research Record 1530. TRB. National Research Council. Washington, D.C., p.3-10. TYREDRAIN (2001). TyreDrain - Erosion Control. Tyre Drain Pty. Ltd. Australia. http://tyredrain.com/ (15 May).

UTWG (2001). Fifth Annual Report of the UTWG. Used Tyre Working Group. United Kingdom, July, 43p.

VAN KIRK, J.; HOLLERAN, G. (2000). Reduced Thickness Asphalt Rubber Concrete Leads to Cost Effective Pavement Rehabilitation. Proceedings of the Asphalt Rubber 2000 Conference. Portugal, p.591-603.

WU, Y.; PARKER JR., F.; KANDHAL, K. (1998). Performance Testing for Hot Mix Asphalt. National Center for Asphalt Technology. NCAT Report No. 98-04. Jan.

ZANZOTTO, L.; KENNEPOHL, G. J. (1996). Development of Rubber and Asphalt Binders by Depolymerization and Devulcanization of Scrap Tires in Asphalt. Transportation Research Record 1530. TRB. National Research Council. Washington, D.C., p. 51-58. 
Resolução no 258 do CONAMA 


\section{MINISTÉRIO DO MEIO AMBIENTE Conselho Nacional do Meio Ambiente - CONAMA}

\section{RESOLUÇÃO Nº 258, DE 26 DE AGOSTO DE 1999}

O CONSELHO NACIONAL DO MEIO AMBIENTE-CONAMA, no uso das atribuições que lhe são conferidas pela Lei $\mathrm{n}^{\circ}$ 6.938, de 31 de agosto de 1981, regulamentada pelo Decreto $n^{0}$ 99.274, de 6 de junho de 1990 e suas alterações, tendo em vista o disposto em seu Regimento Interno, e

Considerando que os pneumáticos inservíveis abandonados ou dispostos inadequadamente constituem passivo ambiental, que resulta em sério risco ao meio ambiente e à saúde pública;

Considerando que não há possibilidade de reaproveitamento desses pneumáticos inservíveis para uso veicular e nem para processos de reforma, tais como recapagem, recauchutagem e remoldagem;

Considerando que uma parte dos pneumáticos novos, depois de usados, pode ser utilizada como matéria prima em processos de reciclagem;

Considerando a necessidade de dar destinação final, de forma ambientalmente adequada e segura, aos pneumáticos inservíveis, resolve:

Art. $1^{\circ}$. As empresas fabricantes e as importadoras de pneumáticos ficam obrigadas a coletar e dar destinação final, ambientalmente adequada, aos pneus inservíveis existentes no território nacional, na proporção definida nesta Resolução relativamente às quantidades fabricadas e/ou importadas.

Parágrafo único. As empresas que realizam processos de reforma ou de destinação final ambientalmente adequada de pneumáticos ficam dispensadas de atender ao disposto neste artigo, exclusivamente no que se refere a utilização dos quantitativos de pneumáticos coletados no território nacional.

Art. $2^{\underline{o}}$. Para os fins do disposto nesta Resolução, considera-se:

I - pneu ou pneumático: todo artefato inflável, constituído basicamente por borracha e materiais de reforço utilizados para rodagem em veículos;

II - pneu ou pneumático novo: aquele que nunca foi utilizado para rodagem sob qualquer forma, enquadrando-se, para efeito de importação, no código 4011 da Tarifa Externa Comum-TEC;

III - pneu ou pneumático reformado: todo pneumático que foi submetido a algum tipo de processo industrial com o fim específico de aumentar sua vida útil de rodagem em meios de transporte, tais como recapagem, recauchutagem ou remoldagem, enquadrando-se, para efeitos de importação, no código 4012.10 da Tarifa Externa Comum-TEC;

IV - pneu ou pneumático inservível: aquele que não mais se presta a processo de reforma que permita condição de rodagem adicional. 
Art. $3^{\circ}$. Os prazos e quantidades para coleta e destinação final, de forma ambientalmente adequada, dos pneumáticos inservíveis de que trata esta Resolução, são os seguintes:

I - a partir de $1^{\circ}$ de janeiro de 2002: para cada quatro pneus novos fabricados no País ou pneus importados, inclusive aqueles que acompanham os veículos importados, as empresas fabricantes e as importadoras deverão dar destinação final a um pneu inservível;

II - a partir de $1^{\circ}$ de janeiro de 2003: para cada dois pneus novos fabricados no País ou pneus importados, inclusive aqueles que acompanham os veículos importados, as empresas fabricantes e as importadoras deverão dar destinação final a um pneu inservível;

III - a partir de $1^{\circ}$ de janeiro de 2004 :

a) para cada um pneu novo fabricado no País ou pneu novo importado, inclusive aqueles que acompanham os veículos importados, as empresas fabricantes e as importadoras deverão dar destinação final a um pneu inservível;

b) para cada quatro pneus reformados importados, de qualquer tipo, as empresas importadoras deverão dar destinação final a cinco pneus inservíveis;

IV - a partir de $1^{\circ}$ de janeiro de 2005 :

a) para cada quatro pneus novos fabricados no País ou pneus novos importados, inclusive aqueles que acompanham os veículos importados, as empresas fabricantes e as importadoras deverão dar destinação final a cinco pneus inservíveis;

b) para cada três pneus reformados importados, de qualquer tipo, as empresas importadoras deverão dar destinação final a quatro pneus inservíveis.

Parágrafo único. $\mathrm{O}$ disposto neste artigo não se aplica aos pneumáticos exportados ou aos que equipam veículos exportados pelo País.

Art. $4^{\circ}$. No quinto ano de vigência desta Resolução, o CONAMA, após avaliação a ser procedida pelo Instituto Brasileiro do Meio Ambiente e dos Recursos Naturais Renováveis - IBAMA, reavaliará as normas e procedimentos estabelecidos nesta Resolução.

Art. 5ํ. O IBAMA poderá adotar, para efeito de fiscalização e controle, a equivalência em peso dos pneumáticos inservíveis.

Art. $6^{\circ}$. As empresas importadoras deverão, a partir de $1^{\circ}$ de janeiro de 2002, comprovar junto ao IBAMA, previamente aos embarques no exterior, a destinação final, de forma ambientalmente adequada, das quantidades de pneus inservíveis estabelecidas no art. $3^{\circ}$ desta Resolução, correspondentes às quantidades a serem importadas, para efeitos de liberação de importação junto ao Departamento de Operações de Comércio Exterior-DECEX, do Ministério do Desenvolvimento, Indústria e Comércio Exterior.

Art. $7^{\circ}$. As empresas fabricantes de pneumáticos deverão, a partir de $1^{\circ}$ de janeiro de 2002, comprovar junto ao IBAMA, anualmente, a destinação final, de forma ambientalmente adequada, das quantidades de pneus inservíveis estabelecidas no art. $3^{\circ}$ desta Resolução, correspondentes às quantidades fabricadas. 
Art. $8^{\underline{o}}$. Os fabricantes e os importadores de pneumáticos poderão efetuar a destinação final, de forma ambientalmente adequada, dos pneus inservíveis de sua responsabilidade, em instalações próprias ou mediante contratação de serviços especializados de terceiros.

Parágrafo único. As instalações para o processamento de pneus inservíveis e a destinação final deverão atender ao disposto na legislação ambiental em vigor, inclusive no que se refere ao licenciamento ambiental.

Art. 9․ A partir da data de publicação desta Resolução fica proibida a destinação final inadequada de pneumáticos inservíveis, tais como a disposição em aterros sanitários, mar, rios, lagos ou riachos, terrenos baldios ou alagadiços, e queima a céu aberto.

Art. $10^{\circ}$. Os fabricantes e os importadores poderão criar centrais de recepção de pneus inservíveis, a serem localizadas e instaladas de acordo com as normas ambientais e demais normas vigentes, para armazenamento temporário e posterior destinação final ambientalmente segura e adequada.

Art. $11^{\circ}$. Os distribuidores, os revendedores e os consumidores finais de pneus, em articulação com os fabricantes, importadores e Poder Público, deverão colaborar na adoção de procedimentos, visando implementar a coleta dos pneus inservíveis existentes no País.

Art. $12^{\circ}$. O não cumprimento do disposto nesta Resolução implicará as sanções estabelecidas na Lei $\mathrm{n}^{0} 9.605$, de 12 de fevereiro de 1998, regulamentada pelo Decreto $\mathrm{n}^{0} 3.179$, de 21 de setembro de 1999.

Art. 13ํ․ Esta Resolução entra em vigor na data de sua publicação.

JOSÉ SARNEY FILHO Presidente do CONAMA
JOSÉ CARLOS CARVALHO

Secretário-Executivo 
Resultados dos Ensaios de Caracterização da Borracha: Porosimetria e Análise Termogravimétrica 
Ensaio de Porosimetria em Mercúrio - Borracha G (fração: 3/8” - \#4)

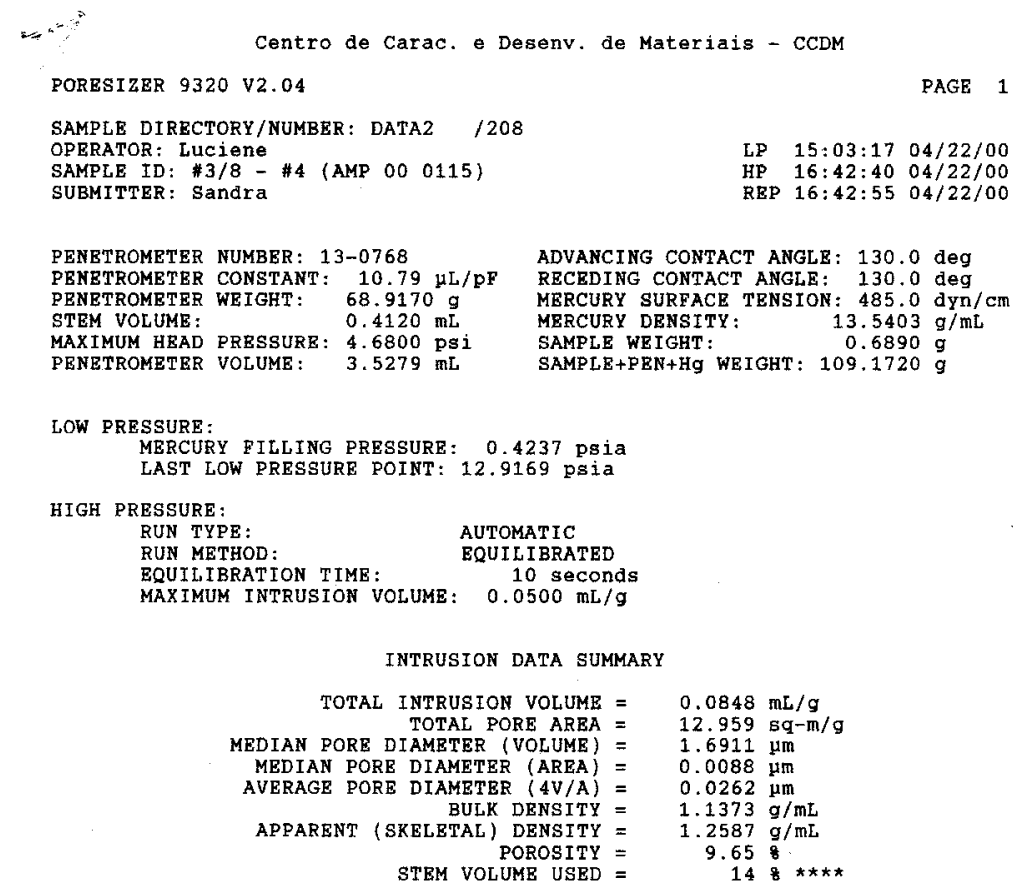

PORESIZER 9320 V2.0

$\begin{array}{lll}L P & 15: 03: 17 & 04 / 22 / 00 \\ \text { HP } & 16: 42: 40 & 04 / 22 / 00 \\ \text { REP } & 16: 42: 55 & 04 / 22 / 00\end{array}$

SAMPLE ID: \#3/8- \#4 (AMP 00 0115)

PENETROMETER NUMBER: $13-0768$ PENETROMBTER WEIGHT: $\begin{array}{ll}\text { STEM VOLUME: } & 0.4120 \mathrm{~mL} \\ \text { MAXIMUM HEA PRESSURE: } & 4.6800 \mathrm{psi} \\ \text { PENETROMETRR VOLUME: } & 3.5279 \mathrm{~mL}\end{array}$

ADVANCING CONTACT ANGLE: 130.0 deg

RECRDING CONTACT ANGLE: 130.0 deg

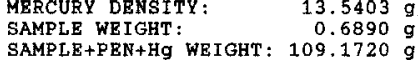

LOW PRESSURE:

MBRCURY FILLING PRESSURE: $0.4237 \mathrm{psia}$

HIGH PRESSURE:

RUN TYPE: $\quad$ AUTOMATIC

EQUILIRRATION TIME: $\quad 10$ seconds

INTRUSION DATA SUMMARY

TOTAL INTRUSION VOLUMR $=0.0848 \mathrm{~mL} / \mathrm{g}$ $\begin{aligned} \text { TOTAL PORE AREA } & =12.959 \mathrm{sq}-\mathrm{m} / \mathrm{g} \\ \text { MEDIAN PORE DIAMRTER (VOLUME) } & 1.6911 \mathrm{\mu m} /\end{aligned}$

MEDIAN PORE DTAMETER (AREA) $=0.0088 \mu \mathrm{m}$

$\begin{aligned} \text { BULK DENSTY } & = \\ \text { APPARENT (SRELETAL) DENSTTY } & 1.1373 \mathrm{~g} / \mathrm{mL} \\ = & 1.2587 \mathrm{~g} / \mathrm{mL}\end{aligned}$

$\begin{array}{rr}\text { POROSTTY }= & 1.2587 \mathrm{~g} / \mathrm{mL} \\ \text { STEM VOLUME USED } & 9.65 \% \\ 148 * * *\end{array}$

PAGE 1
Centro de Carac. e Desenv. de Materiais - CCDM

PORESIZER 9320 V2.04

PAGE 2

SAMPLE DIRECTORY/NUMBER: DATA2 /208

SAMLE ID: \#3/8-\#4 (AMP 000115 )

$\begin{array}{lll}\text { LP } & 15: 03: 17 & 04 / 22 / 00 \\ \text { HP } & 16: 42: 40 & 04 / 22 / 00 \\ \text { REP } & 16: 42: 55 & 04 / 22 / 00\end{array}$

\begin{tabular}{|c|c|c|c|c|c|}
\hline $\begin{array}{c}\text { PORE } \\
\text { DIAMETER } \\
\mu \mathrm{m}\end{array}$ & $\begin{array}{c}\text { CUMULATIVE } \\
\text { VOLUME } \\
\mathrm{mL} / \mathrm{g}\end{array}$ & $\begin{array}{c}\text { INCREMBNTAL } \\
\text { voLuME } \\
\mathrm{mL} / \mathrm{g}\end{array}$ & $\begin{array}{c}\text { DIFFRREN. } \\
\text { VOL } d v / a D \\
\mathrm{~mL} / \mathrm{g}-\mathbf{p m}\end{array}$ & $\begin{array}{c}\text { LOG DIFF. } \\
\text { voL dV/dlogD } \\
\mathrm{mL} / \mathrm{g}\end{array}$ & $\underset{\text { psia }}{\text { PRESSURE }}$ \\
\hline 425.8997 & 0.0000 & 0.0000 & 3. $275 \mathrm{~B}-05$ & $3.292 \mathrm{E}-02$ & \\
\hline 136.8275 & 0.0163 & 0.0163 & 1. $069 \mathrm{E}-04$ & $44 E-02$ & \\
\hline 79.5586 & 0.0250 & 0.0087 & $\frac{1}{2} .7418-04$ & $3.263 \mathrm{E}-02$ & 2.27 \\
\hline $\begin{array}{l}16.4728 \\
52.0046\end{array}$ & $\begin{array}{l}0.0284 \\
0.0306\end{array}$ & $\begin{array}{l}0.0034 \\
0.00222\end{array}$ & $\begin{array}{l}2.127 \mathrm{~B}-04 \\
2.226 \mathrm{~B}-04\end{array}$ & $\begin{array}{l}3.079 \mathrm{E}-02 \\
2.726 \mathrm{E}-02\end{array}$ & $\begin{array}{l}2.94 \\
3.48\end{array}$ \\
\hline 43.2515 & $\begin{array}{l}0.0325 \\
0.0325\end{array}$ & 0.0019 & $2.319 \mathrm{E}-04$ & 2. $362 \mathrm{~B}-02$ & $\begin{array}{l}4.48 \\
4.18\end{array}$ \\
\hline $\begin{array}{l}\begin{array}{l}35.7319 \\
30.2599\end{array}\end{array}$ & 0.0345 & 0.0020 & $2.521 \mathrm{~B}-04$ & $2.122 \mathrm{E}-02$ & 5.06 \\
\hline & $\begin{array}{l}0.0358 \\
0.0371\end{array}$ & $\begin{array}{l}0.0013 \\
0.0013\end{array}$ & $\begin{array}{l}2.561 \mathrm{E}-04 \\
2.752 \mathrm{E}-04\end{array}$ & $\begin{array}{l}1.825 E-02 \\
1.672 E-02\end{array}$ & $\begin{array}{l}5.98 \\
7.01\end{array}$ \\
\hline & $\begin{array}{l}0.0371 \\
0.0379\end{array}$ & 0.0008 & $\begin{array}{l}2.728-04 \\
2.849 \mathrm{~B}-04\end{array}$ & $\begin{array}{l}1.672 \mathrm{E}-02 \\
1.531 \mathrm{E}-02\end{array}$ & $\begin{array}{l}7.01 \\
7.93\end{array}$ \\
\hline 21.1379 & 0.0384 & 0.0005 & $2.963 \mathrm{~B}-04$ & $475 \mathrm{E}-02$ & $\begin{array}{l}8.56 \\
8.56\end{array}$ \\
\hline 19.6929 & 0.0389 & 0.0005 & $3.019 \mathrm{~B}-04$ & $1.400 \mathrm{E}-02$ & \\
\hline 17.8648 & 0.0395 & 0.0006 & $3.066 \mathrm{~B}-04$ & 1. $290 \mathrm{E}-02$ & 10.12 \\
\hline $\begin{array}{l}16.3048 \\
15.0181\end{array}$ & 0.0399 & .0004 & $\begin{array}{l}3.177 \mathrm{~B}-04 \\
3.016 \mathrm{~B}-04\end{array}$ & 1.220E-02 & 11.09 \\
\hline $\begin{array}{l}15.0181 \\
14.0021\end{array}$ & $\begin{array}{l}0.0403 \\
0.0408\end{array}$ & $\begin{array}{l}0.0004 \\
0.0004\end{array}$ & $\begin{array}{l}\frac{3}{3} .0168-04 \\
2.54 E-04\end{array}$ & $\begin{array}{l}1.067 \mathrm{E}-02 \\
8.380 \mathrm{E}-03\end{array}$ & 12.04 \\
\hline $\begin{array}{r}14.0021 \\
7.1792\end{array}$ & $\begin{array}{l}0.0408 \\
0.0410\end{array}$ & $\begin{array}{l}0.0004 \\
0.0002\end{array}$ & $\begin{array}{l}\begin{array}{l}2.5448-04 \\
1.105 \mathrm{~B}-04\end{array}\end{array}$ & $\begin{array}{l}8.380 \mathrm{E}-03 \\
1.872 \mathrm{~B}-03\end{array}$ & $\begin{array}{l}12.92 \\
25.19\end{array}$ \\
\hline 5.1155 & 0.0414 & 0.0004 & $\begin{array}{l}1.1069 \mathrm{~B}-04 \\
1.84\end{array}$ & $2.253 \mathrm{E}-03$ & $\begin{array}{l}35.19 \\
35.36\end{array}$ \\
\hline 3.94 & 0.0416 & 0.0002 & $2.746 \mathrm{~B}-04$ & $2.553 \mathrm{E}-03$ & 45.85 \\
\hline 3.2577 & 0.0419 & 0.0003 & $2.792 \mathrm{E}-04$ & $2.141 \mathrm{E}-03$ & 55.52 \\
\hline & 0.0420 & 0.0001 & $2.150 \mathrm{~B}-04$ & $1.387 \mathrm{E}-03$ & 66.19 \\
\hline 3433 & $\begin{array}{l}0.0421 \\
0.04233\end{array}$ & $\begin{array}{l}0.0001 \\
0.0002\end{array}$ & $\begin{array}{l}4.936 \mathrm{~B}-04 \\
4.980 \mathrm{~B}-04\end{array}$ & $\begin{array}{l}2.723 \mathrm{E}-03 \\
2.471 \mathrm{E}-03\end{array}$ & 77.18 \\
\hline 7700 & $\begin{array}{l}0.0423 \\
0.0424\end{array}$ & $\begin{array}{l}0.0002 \\
0.0001\end{array}$ & 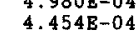 & $\begin{array}{l}2.411 \mathrm{E}-03 \\
1.861 \mathrm{~J}-03\end{array}$ & $\begin{array}{r}85.85 \\
102.18\end{array}$ \\
\hline & $\begin{array}{l}0.0426 \\
0.0426\end{array}$ & $\begin{array}{l}0.0001 \\
0.0002\end{array}$ & $\begin{array}{l}\frac{4.4385-04}{6.598 \mathrm{~B}-04} \\
6\end{array}$ & 1. $308 \mathrm{E}-0.3$ & $\begin{array}{l}121.68 \\
121.68\end{array}$ \\
\hline & 0.0427 & 0.0001 & $5.001 \mathrm{~B}-04$ & $1.513 \mathrm{E}-03$ & 141.01 \\
\hline & 0.0428 & 0.0001 & $4.053 \mathrm{~B}-04$ & $1.077 \mathrm{E}-03$ & 160.35 \\
\hline & 0.0428 & 0.0000 & $6.3068-04$ & $\begin{array}{l}1.499 \mathrm{E}-03 \\
2\end{array}$ & 179.18 \\
\hline & $\begin{array}{l}0.0299 \\
0.0430\end{array}$ & $\begin{array}{l}0.0001 \\
0.0001\end{array}$ & $\begin{array}{l}1.048-03 \\
1.267 \mathrm{~B}-03\end{array}$ & $\begin{array}{l}2.186 \mathrm{E}-03 \\
2.341 \mathrm{E}-03\end{array}$ & $\begin{array}{l}203.01 \\
230.34\end{array}$ \\
\hline & $\begin{array}{l}0.0430 \\
0.0432\end{array}$ & 0.0002 & $1.0778-03$ & $1.766 \mathrm{E}-03$ & $\begin{array}{l}230.34 \\
259.84\end{array}$ \\
\hline & .0432 & 0.0000 & $9.086 \mathrm{~B}-04$ & $\begin{array}{l}1.359 \mathrm{E}-03 \\
1\end{array}$ & $\begin{array}{l}284.51 \\
284.84\end{array}$ \\
\hline & 0.0433 & 0.0001 & $9.642 \mathrm{~B}-04$ & $1.320 \mathrm{E}-03$ & 310.51 \\
\hline & 0.0434 & 0.0001 & $1.507 \mathrm{E}-03$ & $1.808 \mathrm{E}-03$ & 355.84 \\
\hline & & & $2.484 \mathrm{~B}-03$ & $\begin{array}{l}2.583 \mathrm{E}-03 \\
2.7778-03\end{array}$ & 409.67 \\
\hline 3527 & 0.0438 & .0002 & 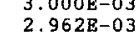 & $\begin{array}{l}2.777 \mathrm{E}-03 \\
2.443 \mathrm{E}-03\end{array}$ & $\begin{array}{l}460.01 \\
512.84\end{array}$ \\
\hline 0.3213 & 0.0438 & 01 & 3. $720 \mathrm{E}-03$ & $2.816 \mathrm{E}-03$ & 562.84 \\
\hline 0.2942 & $\begin{array}{l}0.0439 \\
0.0441\end{array}$ & $\begin{array}{l}0.0001 \\
0.0002\end{array}$ & $\begin{array}{l}4.3718-03 \\
5\end{array}$ & $3.027 \mathrm{E}-03$ & 614.84 \\
\hline & $\begin{array}{l}0.0441 \\
0.0441\end{array}$ & $\begin{array}{l}0002 \\
0000\end{array}$ & $.028 \mathrm{E}$ & 194 & $\begin{array}{l}17 \\
67\end{array}$ \\
\hline & & & & $19 \mathrm{E}$ & \\
\hline & & & 3 & קבק & \\
\hline & 0444 & & 3 & $652 \mathrm{E}$ & \\
\hline & 3445 & 0001 & $510 \mathrm{E}-03$ & $977 \mathrm{E}-03$ & 913.33 \\
\hline
\end{tabular}


Ensaio de Porosimetria em Mercúrio - Borracha G (fração: 3/8” - \#4) - continuação

Centro de Carac. e Desenv. de Materiais - CCDM

PORESIZER 9320 V2.04

SAMPLE DIRBCTORY/NUMBRR: DATA2 /208 OPRRATOR: Luciene
SAMPLE TD: \#3/8 $-\# 4$ (AMP 000115 )
SUBMITTER: Sandra

PAGE 3

$\begin{array}{lll}\text { LP } & 15: 03: 17 & 04 / 22 / 00 \\ \text { HP } & 16: 42: 40 & 04 / 22 / 00 \\ \text { REP } & 16: 42: 55 & 04 / 22 / 00\end{array}$

\begin{tabular}{|c|c|c|c|c|c|}
\hline $\begin{array}{c}\text { PORE } \\
\text { DIAMETRR } \\
\text { Mm }\end{array}$ & $\begin{array}{l}\text { CUMULATIVE } \\
\text { VOLUME } \\
\mathrm{mL} / \mathrm{g}\end{array}$ & $\begin{array}{c}\text { INCREMENTAL } \\
\text { VoLUMR } \\
\mathrm{mL} / \mathrm{g}\end{array}$ & $\begin{array}{l}\text { DIFPRRBN. } \\
\text { VOL dV/AD } \\
\mathrm{mL} / \mathrm{g}-\mu \mathrm{m}\end{array}$ & $\begin{array}{l}\mathrm{LOG} \mathrm{DIFF} \\
\text { vOL } \mathrm{dV} / \mathrm{d} \log \mathrm{D} \\
\mathrm{mL} / \mathrm{g}\end{array}$ & $\underset{\substack{\text { PRSSUIR } \\
\text { psia }}}{ }$ \\
\hline 0. & 0.0446 & 0 & 1 & $4.524 \mathrm{~B}-03$ & \\
\hline & & & & & 1010 \\
\hline $\begin{array}{l}1622 \\
1487\end{array}$ & 0.0451 & 0.0002 & $\begin{array}{l}1.217 \mathrm{E}-02 \\
1.388 \mathrm{E}-02\end{array}$ & $\begin{array}{l}4.648 \mathrm{~B}-03 \\
4.868 \mathrm{~B}-03\end{array}$ & $\begin{array}{l}1115.33 \\
1216.00\end{array}$ \\
\hline 1377 & 0.0452 & 0.0000 & $1.745 \mathrm{E}-02$ & $5.655 \mathrm{~B}-03$ & 1313. \\
\hline & $\begin{array}{l}0.0454 \\
0.0457\end{array}$ & $\begin{array}{l}0.0002 \\
0.0003\end{array}$ & $\begin{array}{l}2.121 \mathrm{EE}-02 \\
2.486 \mathrm{E}-02\end{array}$ & $\begin{array}{l}6.4 \\
6.9\end{array}$ & $\begin{array}{l}1410 . \\
1518\end{array}$ \\
\hline & 0.0459 & 0.0002 & $2.820 \mathrm{E}-02$ & 7.466 & 1607. \\
\hline 7 & 0.0461 & 0.0002 & 3.121E-02 & 7.766 & 1711. \\
\hline & & 0.0 & 02 & & $\begin{array}{l}1811 . \\
1907 .\end{array}$ \\
\hline $\begin{array}{l}8 \\
1\end{array}$ & $\begin{array}{l}0.0 \\
0.0\end{array}$ & $\begin{array}{l}0.0 \\
0.0\end{array}$ & $\begin{array}{r}3.707 \mathrm{E}-02 \\
3.942 \mathrm{E}-02\end{array}$ & & $\begin{array}{l}1907 . \\
2007 .\end{array}$ \\
\hline & & & & & \\
\hline $\begin{array}{l}0.0751 \\
0.0694\end{array}$ & $\begin{array}{l}0.0473 \\
0.0477\end{array}$ & $\begin{array}{l}0.0 \\
0.0\end{array}$ & & & 2607. \\
\hline 0.0644 & 0.0480 & 0.0003 & $8.104 \mathrm{E}-02$ & $1.229 \mathrm{E}-02$ & 2808 \\
\hline 0.0 & & & & & $\begin{array}{l}3007 \\
3508\end{array}$ \\
\hline $\begin{array}{l}5 \\
2 \\
5\end{array}$ & $\begin{array}{l}0.0493 \\
0.0501\end{array}$ & $\begin{array}{l}0.0008 \\
0.0008\end{array}$ & $\begin{array}{l}1.990 \mathrm{E}-01 \\
1.276 \mathrm{E}-01\end{array}$ & $\begin{array}{l}1.3238 \mathrm{E}-02 \\
1.358 \mathrm{~B}-02\end{array}$ & $\begin{array}{l}3508 . \\
4002 .\end{array}$ \\
\hline & & & & & 4497. \\
\hline $\begin{array}{l}0.0 \\
0.0\end{array}$ & & $\begin{array}{l}0.0 \\
0.0\end{array}$ & $\begin{array}{l}2.0 \\
2.4\end{array}$ & & $\begin{array}{l}4997 . \\
5496 .\end{array}$ \\
\hline 2 & 0.0 & & $2.951 \mathrm{~B}-01$ & & 5997. \\
\hline & & & & & $\begin{array}{l}6494 \\
6997 \\
\end{array}$ \\
\hline $\begin{array}{l}0.0 \\
0.0\end{array}$ & $\begin{array}{l}0.0545 \\
0.0554\end{array}$ & $\begin{array}{l}0.0007 \\
0.0008\end{array}$ & $\begin{array}{l}4.152 \\
4.741\end{array}$ & & 7492. \\
\hline & & & & & 150. \\
\hline $\begin{array}{l}0.0 \\
0.0\end{array}$ & $\begin{array}{l}0.0569 \\
0.0576\end{array}$ & & & & 8995.58 \\
\hline 0 & & & 7.2 & & 9491.91 \\
\hline & & & & & $\begin{array}{r}9992 \\
10989\end{array}$ \\
\hline & & & & & $\begin{array}{l}10989 . \\
11988 .\end{array}$ \\
\hline & & & & & 124 \\
\hline & & & & & $\begin{array}{l}13986 . \\
14982 .\end{array}$ \\
\hline & & & & & $\begin{array}{l}14982.86 \\
15981.19\end{array}$ \\
\hline & & & 2.1 & & \\
\hline & & & 2.3 & & \\
\hline .00 & & 0.0 & $\begin{array}{l}2.5 \\
2.6\end{array}$ & 5.748 & 997 \\
\hline & & & & 02 & \\
\hline & & & & & \\
\hline .006 & .0819 & $\begin{array}{l}0.0024 \\
0.00222\end{array}$ & $\begin{array}{l}4.680 \mathrm{E}+00 \\
5.598 \mathrm{E}+00\end{array}$ & $\begin{array}{l}7.679 \mathrm{E}-02 \\
8.528 \mathrm{E}-02\end{array}$ & $\begin{array}{l}25957 \\
27955\end{array}$ \\
\hline & & & & & \\
\hline
\end{tabular}

Centro de Carac. e Desenv. de Materiais - CCDM

PORESIZER 9320 V2.04

PAGE 4

SAMPLE DIRECTORY/NUMBER: DATA2 /208

OPERATOR: LUCIERE
SAMPE ID: \#3/8- \#4 (AMP 00 0115)
SUMMTTTER: Sandra

$\begin{array}{lll}\text { LP } & 15: 03: 17 & 04 / 22 / 00 \\ \text { HP } & 16: 42: 40 & 04 / 2200 \\ \text { REP } & 16: 42: 55 & 04 / 22 / 00\end{array}$

\begin{tabular}{|c|c|c|c|c|c|}
\hline $\begin{array}{c}\text { PORE } \\
\text { DIAMETER } \\
\mu \mathrm{m}\end{array}$ & $\begin{array}{c}\text { CUMULATIVE } \\
\text { VOLUME } \\
\mathrm{mL} / \mathrm{g}\end{array}$ & $\begin{array}{l}\text { INCREMENTAL } \\
\text { VOLUME } \\
\mathrm{mL} / \mathrm{g}\end{array}$ & 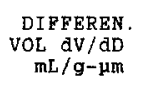 & $\begin{array}{l}\text { LOG DIFF } \\
\text { VOL } \mathrm{dV} / \mathrm{dLO} \mathrm{DD} \\
\mathrm{mL} / \mathrm{g}\end{array}$ & $\underset{\substack{\text { PRgsia } \\
\text { psiaR }}}{ }$ \\
\hline $\begin{array}{l}0.0062 \\
0.0061\end{array}$ & $\begin{array}{l}0.0838 \\
0.0848\end{array}$ & $\begin{array}{l}0.0019 \\
0.0011\end{array}$ & $\begin{array}{l}5.909 \mathrm{~B}+00 \\
6.095 \mathrm{E}+00\end{array}$ & $\begin{array}{l}8.693 \mathrm{E}-02 \\
8.727 \mathrm{E}-02\end{array}$ & $\begin{array}{r}28953.08 \\
29746.57\end{array}$ \\
\hline $\begin{array}{l}0.0061 \\
0.0062 \\
0.0065\end{array}$ & $\begin{array}{l}.0845 \\
0840\end{array}$ & $\begin{array}{l}-0.0003 \\
-0.0005\end{array}$ & $\begin{array}{l}2.186 \mathrm{E}+00 \\
2.113 \mathrm{E}+00\end{array}$ & $\begin{array}{l}3.095 \mathrm{E}-02 \\
3.097 \mathrm{~B}-02\end{array}$ & $\begin{array}{r}2854.58 \\
27964.75\end{array}$ \\
\hline 0.0067 & 0.0835 & -0.0005 & $2.041 \mathrm{~B}+00$ & $3.098 \mathrm{E}-02$ & 26972.41 \\
\hline 0.0070 & 0.0830 & $\begin{array}{l}-0.0005 \\
-0.0006\end{array}$ & $\begin{array}{l}2.040 \mathrm{E}+00 \\
2.029 \mathrm{~B}+00\end{array}$ & $\begin{array}{l}3.218 \mathrm{E}-02 \\
3_{3} 328 \mathrm{~B}-02\end{array}$ & $\begin{array}{r}25974.75 \\
2484.42\end{array}$ \\
\hline 0.0075 & 0.0819 & $\begin{array}{l}-0.0000 \\
-0.0005\end{array}$ & $2.031 \mathrm{E}+00$ & $3.470 \mathrm{E}-02$ & $\begin{array}{l}24384.42 \\
23984.09\end{array}$ \\
\hline 0.0079 & 0.0812 & -0.0008 & $2.039 \mathrm{~B}+00$ & 3. $635 \mathrm{E}-02$ & 22986.09 \\
\hline $\begin{array}{l}0.0082 \\
0.0090\end{array}$ & $\begin{array}{l}.08805 \\
0.0789\end{array}$ & $\begin{array}{l}-0.0007 \\
-0.0016\end{array}$ & $\begin{array}{l}2.012 \mathrm{E}+00 \\
1.876 \mathrm{E}+00\end{array}$ & 3.846E-02 & $\begin{array}{l}21990.09 \\
19989.10\end{array}$ \\
\hline 0.0095 & 0.0780 & -0.0009 & $1.748 \mathrm{E}+00$ & $3.771 \mathrm{E}-02$ & 18992.94 \\
\hline 0.0101 & 0.0771 & -0.0010 & $1.621 \mathrm{E}+00$ & $3.691 \mathrm{E}-02$ & 17996.28 \\
\hline 0.0106 & $\begin{array}{l}0.0763 \\
0.0753\end{array}$ & $\begin{array}{l}-0.0008 \\
-0.0010\end{array}$ & $\begin{array}{l}1.498 \mathrm{~B}+00 \\
1.319 \mathrm{R}+00\end{array}$ & $3.613 \mathrm{E}-02$ & $\begin{array}{r}16992.78 \\
1599.12\end{array}$ \\
\hline $\begin{array}{l}0.0113 \\
0.0121\end{array}$ & $\begin{array}{l}0.0753 \\
0.0743\end{array}$ & $\begin{array}{l}-0.0010 \\
-0.0010\end{array}$ & $\begin{array}{l}1.319 \mathrm{E}+00 \\
1.230 \mathrm{E}+00\end{array}$ & $\begin{array}{l}3.382 \mathrm{E}-02 \\
3.360 \mathrm{E}-02\end{array}$ & $\begin{array}{l}15992.12 \\
14997.29\end{array}$ \\
\hline 0.0129 & 0.0735 & -0.0008 & $1.151 \mathrm{E}+00$ & $3.372 \mathrm{E}-02$ & 13992.47 \\
\hline $\begin{array}{l}0.0139 \\
0.0151\end{array}$ & $\begin{array}{l}0.0722 \\
0.0711\end{array}$ & $\begin{array}{l}-0.0013 \\
-0.0011\end{array}$ & $\begin{array}{l}1.094 \mathrm{~B}+00 \\
9\end{array}$ & $\begin{array}{l}3.453 \mathrm{~B}-02 \\
3.379 \mathrm{E}-02\end{array}$ & $\begin{array}{l}12987.14 \\
11195.81\end{array}$ \\
\hline $\begin{array}{l}0.0151 \\
0.0164\end{array}$ & $\begin{array}{l}0.07111 \\
0.0698\end{array}$ & $\begin{array}{l}-0.0011 \\
-0.0012\end{array}$ & $\begin{array}{l}9.893 \mathrm{~B}-01 \\
8.765 \mathrm{~B}-01\end{array}$ & $\begin{array}{r}3.379 \mathrm{E}-02 \\
3.367 \mathrm{~B}-02\end{array}$ & $\begin{array}{l}11995.81 \\
10996.99\end{array}$ \\
\hline 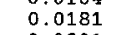 & 0.0685 & $\begin{array}{l}-0.0012 \\
-0.0014\end{array}$ & $\begin{array}{l}8.765 \mathrm{E}-01 \\
7.695 \mathrm{E}-01\end{array}$ & $\begin{array}{l}3.267 \mathrm{E}-02 \\
3.155 \mathrm{~B}-02\end{array}$ & $\begin{array}{r}19996.99 \\
9994.83 \\
\end{array}$ \\
\hline & 0.0671 & & 6. $364 \mathrm{E}-01$ & 2. $900 \mathrm{~B}-02$ & 8995.17 \\
\hline & 0.0657 & -0.0014 & $5.455 \mathrm{E}-01$ & $2.796 \mathrm{E}-02$ & 7995.85 \\
\hline & $\begin{array}{l}0.0540 \\
0.0527\end{array}$ & $\begin{array}{l}-0.0016 \\
-0.0014\end{array}$ & $4.174 \mathrm{E}-01$ & $2.445 \mathrm{~B}-02$ & $\begin{array}{l}6996.36 \\
6000.70\end{array}$ \\
\hline 362 & 0.0609 & $\begin{array}{l}-0.0014 \\
-0.0018\end{array}$ & $2.672 \mathrm{~B}-01$ & $2.191 \mathrm{E}-02$ & $\begin{array}{l}4999.55 \\
\end{array}$ \\
\hline 0.0453 & 0.0589 & -0.0019 & $1.752 \mathrm{E}-01$ & $1.797 \mathrm{E}-02$ & 3996.89 \\
\hline $\begin{array}{l}0.0603 \\
0.0906\end{array}$ & $\begin{array}{l}0.0570 \\
0.0551\end{array}$ & $\begin{array}{l}-0.0019 \\
-0.0019\end{array}$ & $\begin{array}{r}9.545 \mathrm{~B}-02 \\
4.306 \mathrm{~B}-02\end{array}$ & $\begin{array}{l}1.304 \mathrm{E}-02 \\
8.840 \mathrm{~B}-03\end{array}$ & $\begin{array}{l}2998.74 \\
1996.09\end{array}$ \\
\hline 0.18 & 0.0530 & -0.0021 & $2.491 \mathrm{E}-02$ & $1.027 \mathrm{E}-02$ & 1001.43 \\
\hline 0.1901 & 0.0528 & -0.0002 & $2.3478-02$ & $1.011 \mathrm{E}-02$ & 951.27 \\
\hline 0.2141 & $\begin{array}{l}0.0524 \\
0.0523\end{array}$ & $\begin{array}{l}-0.0004 \\
-0.0001\end{array}$ & $\begin{array}{l}2.151 \mathrm{~B}-02 \\
1.871 \mathrm{~B}-02\end{array}$ & $\begin{array}{l}9.809 \mathrm{E}-03 \\
9.077 \mathrm{E}-03\end{array}$ & $\begin{array}{l}898.77 \\
844.77\end{array}$ \\
\hline & & & & & 77 \\
\hline 0.2438 & $\begin{array}{l}0.0517 \\
0.0515\end{array}$ & -0.0003 & $1.524 \mathrm{E}-02$ & -03 & 741.94 \\
\hline & $\begin{array}{l}0.0515 \\
0.0512\end{array}$ & 002 & .296 & $\begin{array}{l}8.1 \\
8.2\end{array}$ & $\begin{array}{l}691.94 \\
641.78\end{array}$ \\
\hline & 4 & & 2 & & \\
\hline & & & & & \\
\hline & & & & 1 & 485.79 \\
\hline & & & & & \\
\hline & & & & & \\
\hline & & & & & \\
\hline 75 & & & $\mathrm{OE}$ & $36 \mathrm{~B}-03$ & 238.96 \\
\hline
\end{tabular}


Ensaio de Porosimetria em Mercúrio - Borracha G (fração: 3/8” - \#4) - continuação

Centro de carac. E Desenv. de Materiais - CCDM

PORESI ZER 9320 V2.04

SAMPLE DIRBCTORY/NUMBER: DATA2 /208

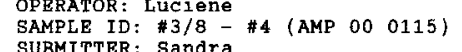

\begin{tabular}{|c|c|c|c|c|c|}
\hline $\begin{array}{c}\text { PORE } \\
\text { DIAMETER } \\
\mathrm{\mu m}\end{array}$ & $\begin{array}{l}\text { CUMULATIVB } \\
\text { VOLUME } \\
\mathrm{mE} / \mathrm{g}\end{array}$ & $\begin{array}{c}\text { INCREMENTAL } \\
\text { VOLUME } \\
\mathrm{mL} / \mathrm{g}\end{array}$ & $\begin{array}{l}\text { DIFPERREN. } \\
\text { VOL dV/dD } \\
\mathrm{mL} / \mathrm{g}-\mu \mathrm{m}\end{array}$ & $\begin{array}{l}\text { LOG DIFF. } \\
\text { VOL } \mathrm{dV} / \mathrm{al} \text {. } \\
\mathrm{mL} / \mathrm{g} D\end{array}$ & $\begin{array}{c}\text { PRESSURE } \\
\text { psia }\end{array}$ \\
\hline $\begin{array}{r}0.9357 \\
1.0457 \\
1.2087 \\
1.4097 \\
1.5777 \\
2.0637 \\
2.2805 \\
2.5663 \\
2.8196 \\
3.8226 \\
4.3955 \\
5.8063 \\
7.7568 \\
12.0696 \\
15.0821 \\
18.4049\end{array}$ & $\begin{array}{l}0.0486 \\
0.0485 \\
0.0483 \\
0.0481 \\
0.0480 \\
0.0477 \\
0.0476 \\
0.0474 \\
0.0471 \\
0.0468 \\
0.0468 \\
0.0465 \\
0.0464 \\
0.0462 \\
0.0453 \\
0.0451\end{array}$ & $\begin{array}{l}-0.0003 \\
-0.0001 \\
-0.0002 \\
-0.0002 \\
-0.0001 \\
-0.0003 \\
-0.0002 \\
-0.0002 \\
-0.0003 \\
-0.0003 \\
-0.0001 \\
-0.0002 \\
-0.0001 \\
-0.0002 \\
-0.0009 \\
-0.0002\end{array}$ & $\begin{array}{l}1.4798-03 \\
1.303 \mathrm{E}-03 \\
1.210 \mathrm{E}-03 \\
7.09 \mathrm{E}-04 \\
5.593 \mathrm{E}-04 \\
6.969 \mathrm{E}-04 \\
6.791 \mathrm{E}-04 \\
8.964 \mathrm{E}-04 \\
7.775 \mathrm{E}-04 \\
1.261 \mathrm{E}-04 \\
1.467 \mathrm{E}-04 \\
9.981 \mathrm{E}-05 \\
4.785 \mathrm{E}-05 \\
1.764 \mathrm{E}-04 \\
1.692-04 \\
5.789 \mathrm{E}-04\end{array}$ & $\begin{array}{l}3.139 \mathrm{~B}-03 \\
3.088 \mathrm{E}-03 \\
3.314 \mathrm{E}-03 \\
2.268 \mathrm{~B}-03 \\
2.000 \mathrm{~B}-03 \\
3.259 \mathrm{E}-03 \\
3.507 \mathrm{E}-03 \\
5.212 \mathrm{~B}-03 \\
4.967 \mathrm{E}-03 \\
1.092 \mathrm{E}-03 \\
1.462 \mathrm{E}-03 \\
1.313 \mathrm{E}-03 \\
8.411 \mathrm{E}-04 \\
4.823 \mathrm{E}-03 \\
5.773 \mathrm{E}-03 \\
2.414 \mathrm{E}-03\end{array}$ & $\begin{array}{r}193.30 \\
172.97 \\
149.64 \\
128.30 \\
114.64 \\
87.64 \\
79.31 \\
70.48 \\
64.14 \\
47.31 \\
41.15 \\
31.15 \\
23.32 \\
14.99 \\
11.99 \\
9.83\end{array}$ \\
\hline
\end{tabular}

Centro de Carac. e Desenv. de Materiais - CCDM

PORESIZBR 9320 V2.04

PAGE 6

\section{SAMPLE DIRECTORY/NUMBER: DATA2//208}

SAMPLE ID: \#3/8- \#4 (AMP 000115 )

$\begin{array}{lll}\text { LP } & 15: 03: 17 & 04 / 22 / 00\end{array}$

$\operatorname{HP}_{\operatorname{REP}} 16: 42: 40 \quad 04 / 22 / 00$

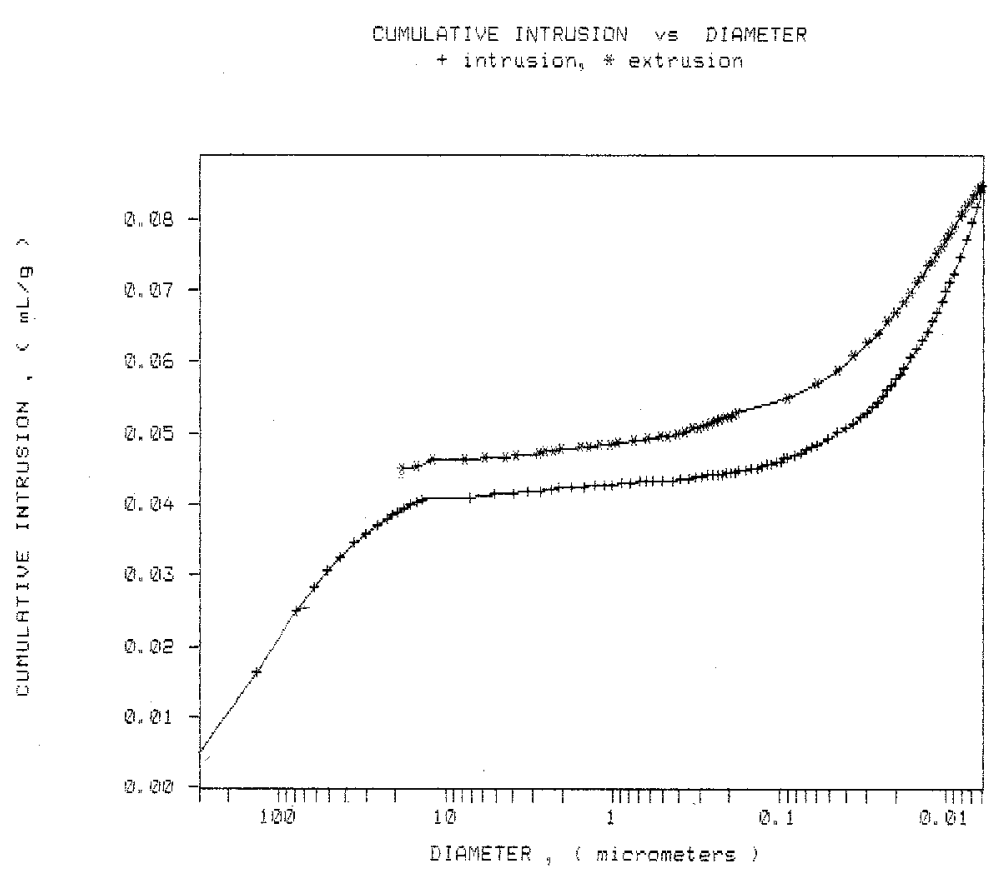


Ensaio de Porosimetria em Mercúrio - Borracha G (fração: 3/8” - \#4) - continuação

\section{PORESIZER 9320 V2.04}

SAMPLE DIRECTORY/NUMBER: DATA2 /208

OPERATOR: Luciene
SAMPLE ID: \#3/8- \#4 (AMP 000115 )
SUBMITIER: Sandra
\end{abstract}

Centro de Carac. E Desenv. de Materiais - CCDM

SAMPLE ID: *3/8

INCREMENTAL INTRUSION $\vee \equiv$ DIAMETER

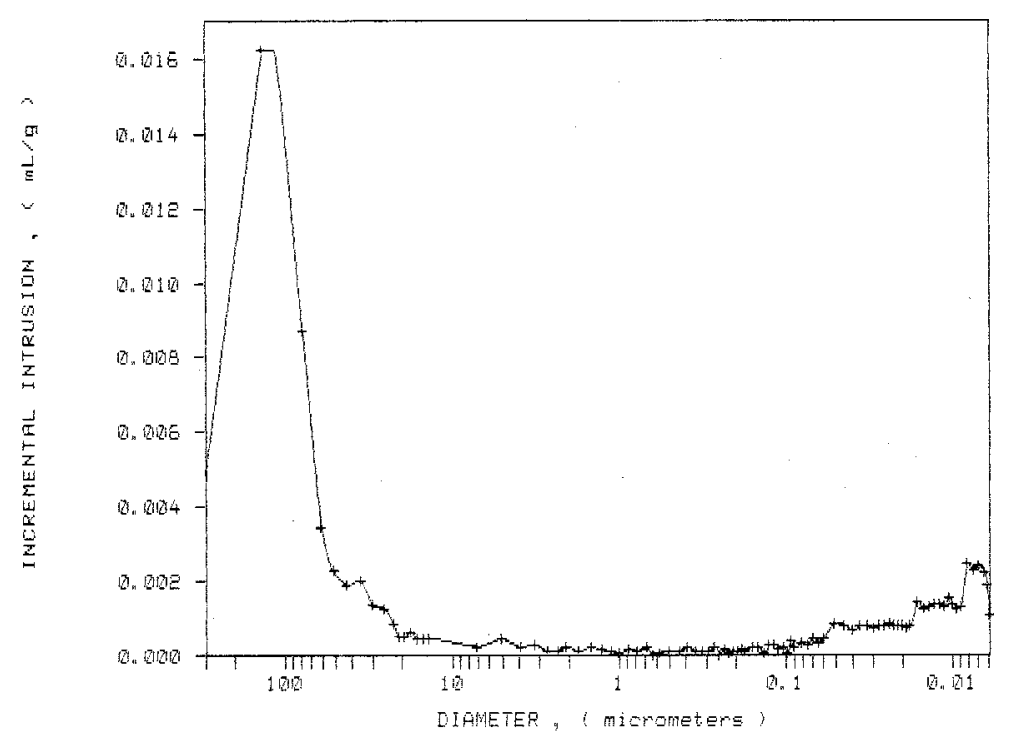

PAGE 7

LP $15: 03: 17 \quad 04 / 22 / 00$
REP $16: 42: 55 \quad 04 / 22 / 00$
PORESIZER 9320 V2.04

SAMPLE DIRBCTORY/NUMBER: DATA2/208

OPERATOR: LUCiene

SAMPLE ID: :3/8-
SUBMTTERR: Sandra
Centro de Carac. E Desenv. de Materiais - CCDM

PAGE

LP $\quad 15: 03: 17 \quad 04 / 22 / 00$ REP $16: 42: 55 \quad 04 / 22 / 00$
LGG DIFFERENTIOL INTRUSION $v$ DIAMETEP

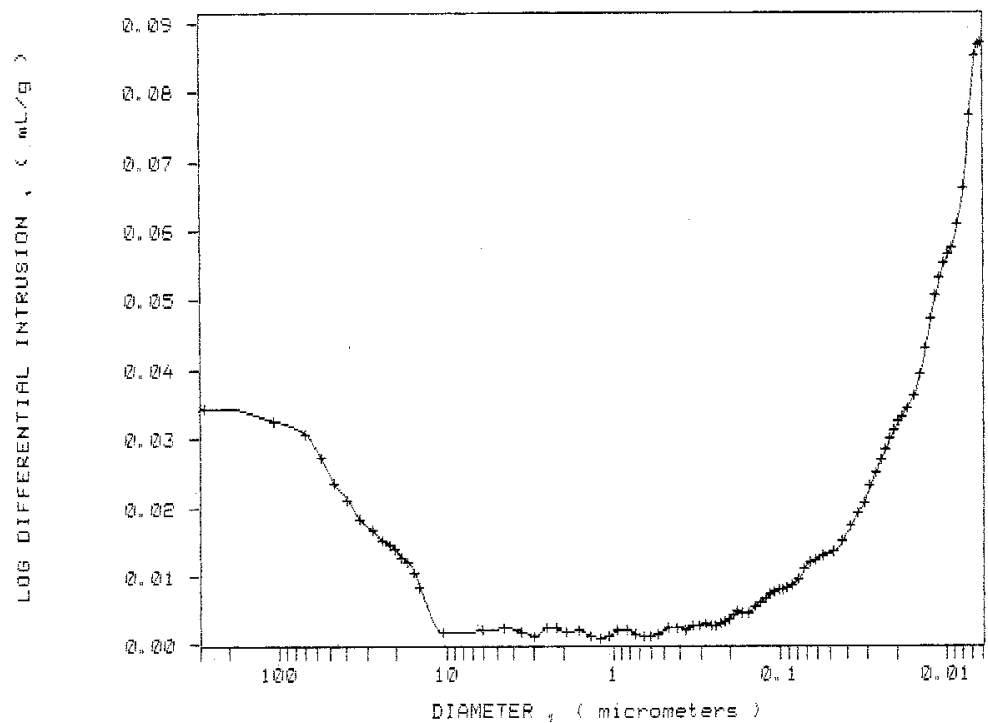


Ensaio de Porosimetria em Mercúrio - Borracha G (fração: 3/8” - \#4) - continuação

- Centro de Carac. e Desenv. de Materiais - CCDM

PORESIZER 9320 V2.04

PAGE 10 SAMPLE DIRBCTORY/NUMBER：DATA2 /208

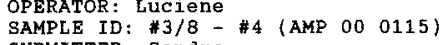

LP $\quad$ 15:03:17 $04 / 22 / 00$ $\begin{array}{lll}H P & 16: 42: 40 & 04 / 22 / 00 \\ \text { REP } & 16: 42: 55 & 04 / 22 / 00\end{array}$

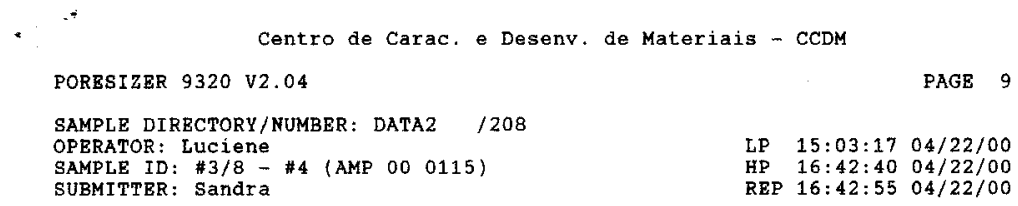

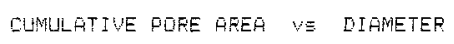

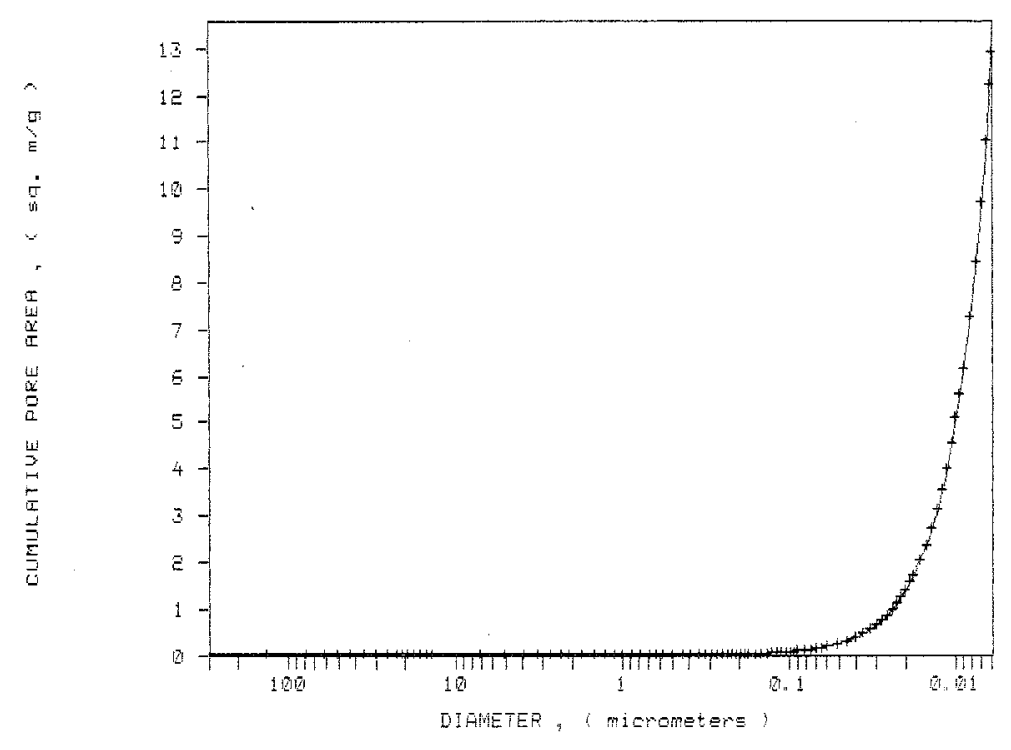

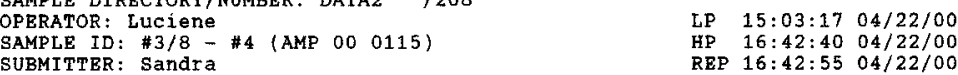

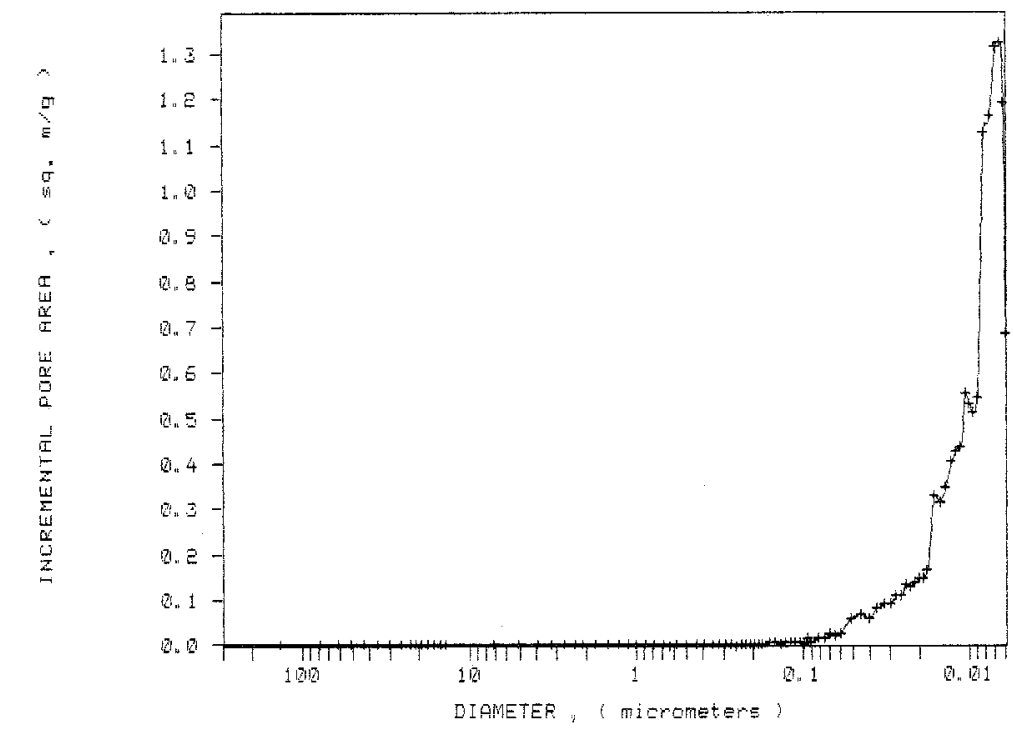


Ensaio de Porosimetria em Mercúrio - Borracha G (fração: \#16 - \#30)

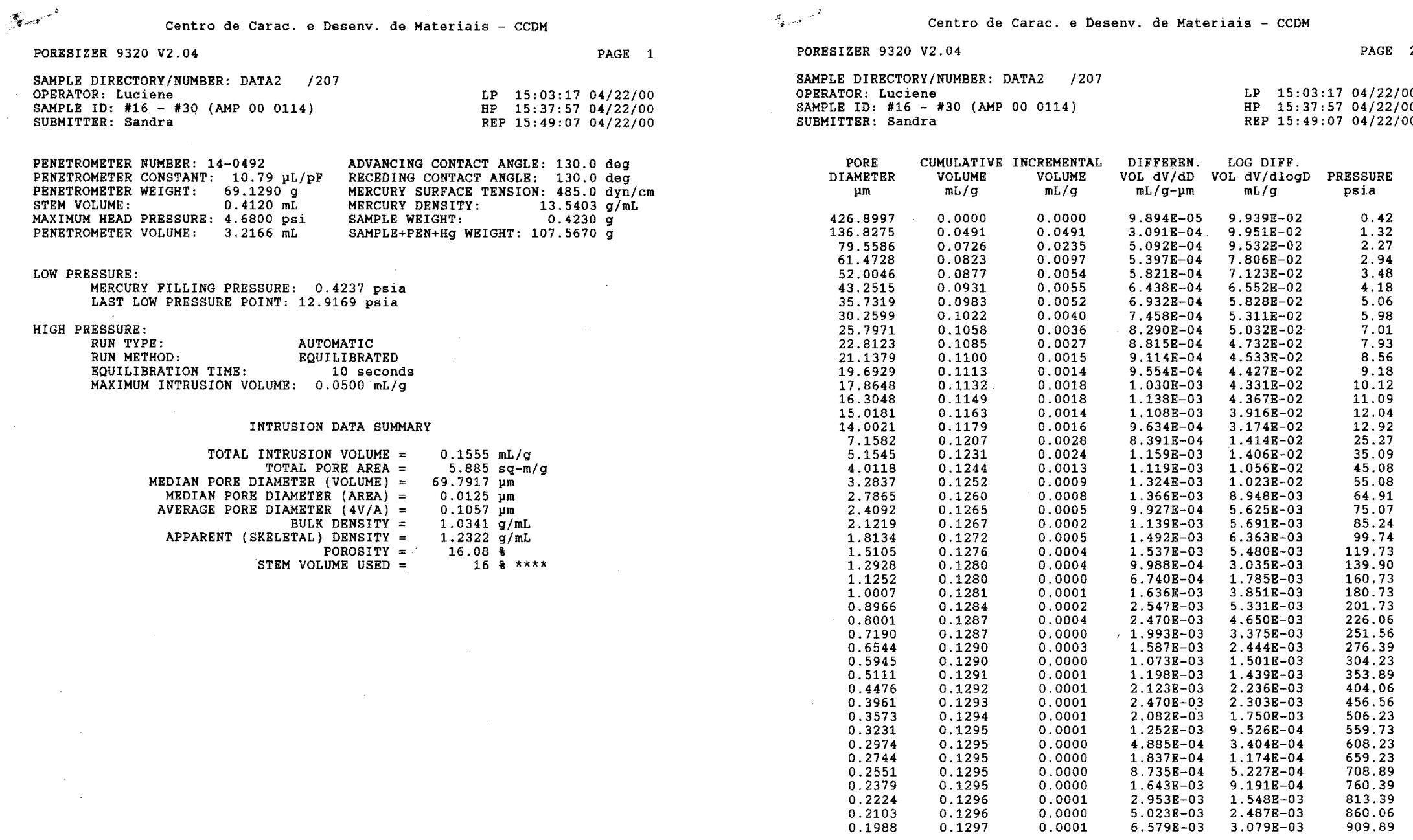


Ensaio de Porosimetria em Mercúrio - Borracha G (fração: \#16 - \#30) - continuação

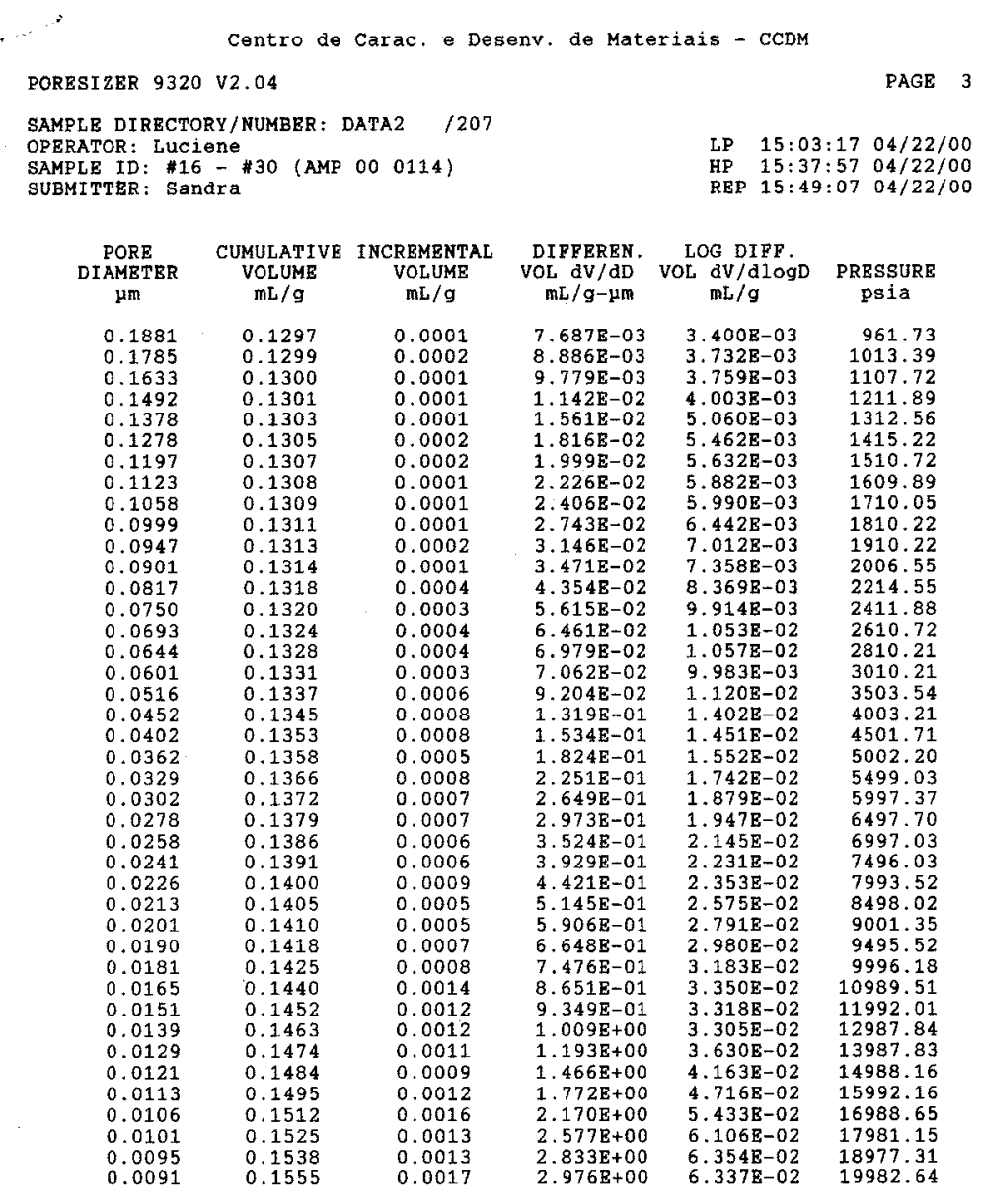
SAMPLE DIRECTORY/NUMBER: DATA2 /207
OPERATOR: LUC1Ene
SAMPLE ID: $\$ 16-\# 30$ (AMP 00 0114)
$\begin{array}{lll}\text { HP } & 15: 03: 17 & 04 / 22 / 00 \\ \text { REP } & 15: 49: 57 & 04 / 22 / 00 \\ 0 & 04 / 22 / 00\end{array}$
PAGE 4 
Ensaio de Porosimetria em Mercúrio - Borracha G (fração: \#16 - \#30) - continuação

Aentro de Carac. e Desenv. de Materiais - CCDM

PORESIZER 9320 V2.04

PAGE 5

OPERAEORIRBCTORY/NUMBER: DATA2 /207

SAMPLE ID: : $\$ 16-\# 30$ (AMP 00 0114)

PP $15: 03: 17 \quad 04 / 22 / 00$

HP $15: 37: 57 \quad 04 / 22 / 00$

INCREIIENTAL INTFIJION VE DIAMETER

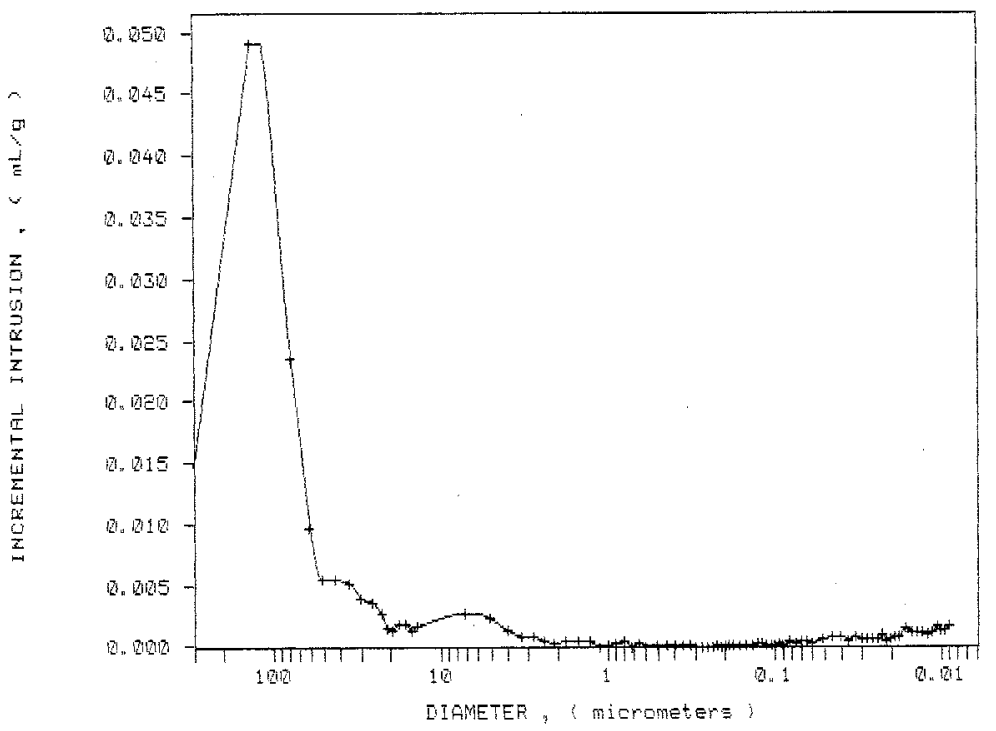

GIGMETER, \& micrometers r

PORESIZER 9320 v2.04

PAGE 6

SAMPLB DIRECTORY/NUMBER: DATA2 /207

SAMLE ID: \#16-\#30 (AMP 00 0114)
SUPMITTE: Sandra

$15: 03: 17 \quad 04 / 22 / 00$

REP 15:49:07 04/22/00
LOE DIFHERENTIAL INTRUSION $v \equiv$ DIOMETE

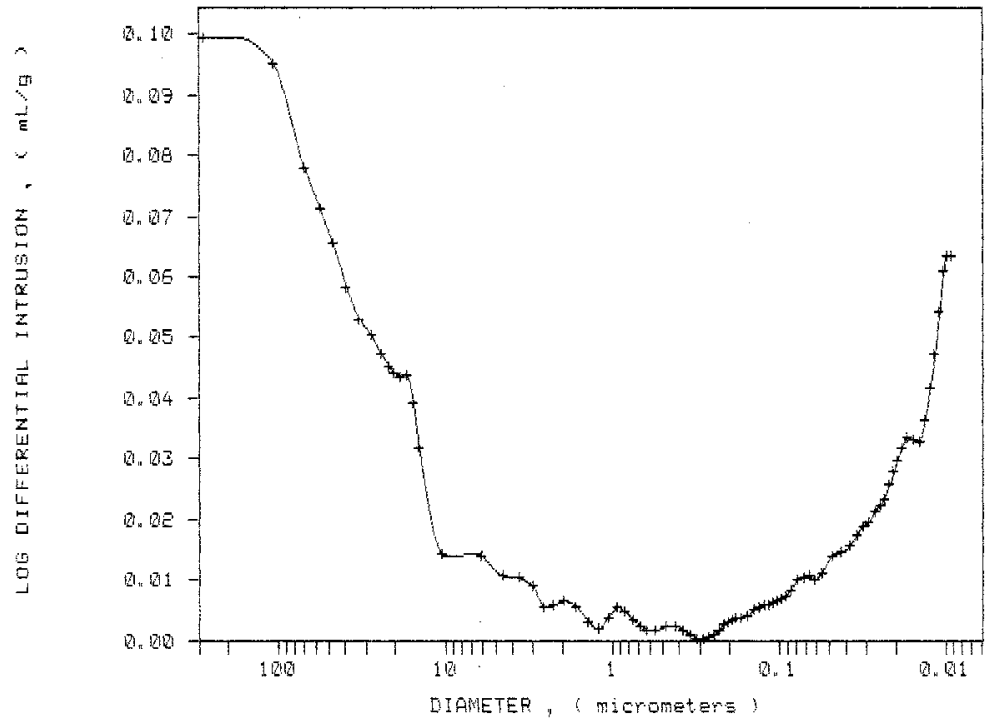


Ensaio de Porosimetria em Mercúrio - Borracha G (fração: \#16 - \#30) - continuação

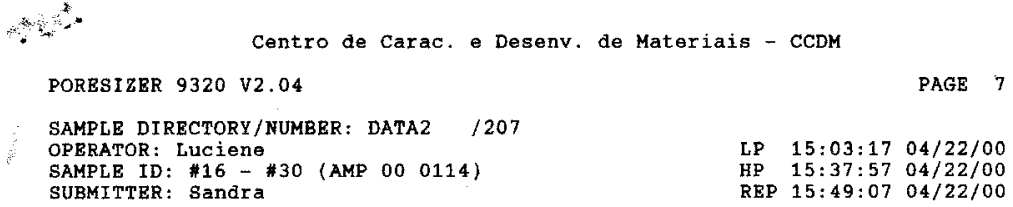

PAGE 7

SAMPLE DIRECTORY/NUMBER: DATA2 /207

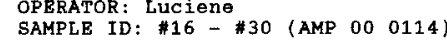

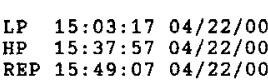

CLMULGTIVE PGRE GFEA $y$ DIAMETEF

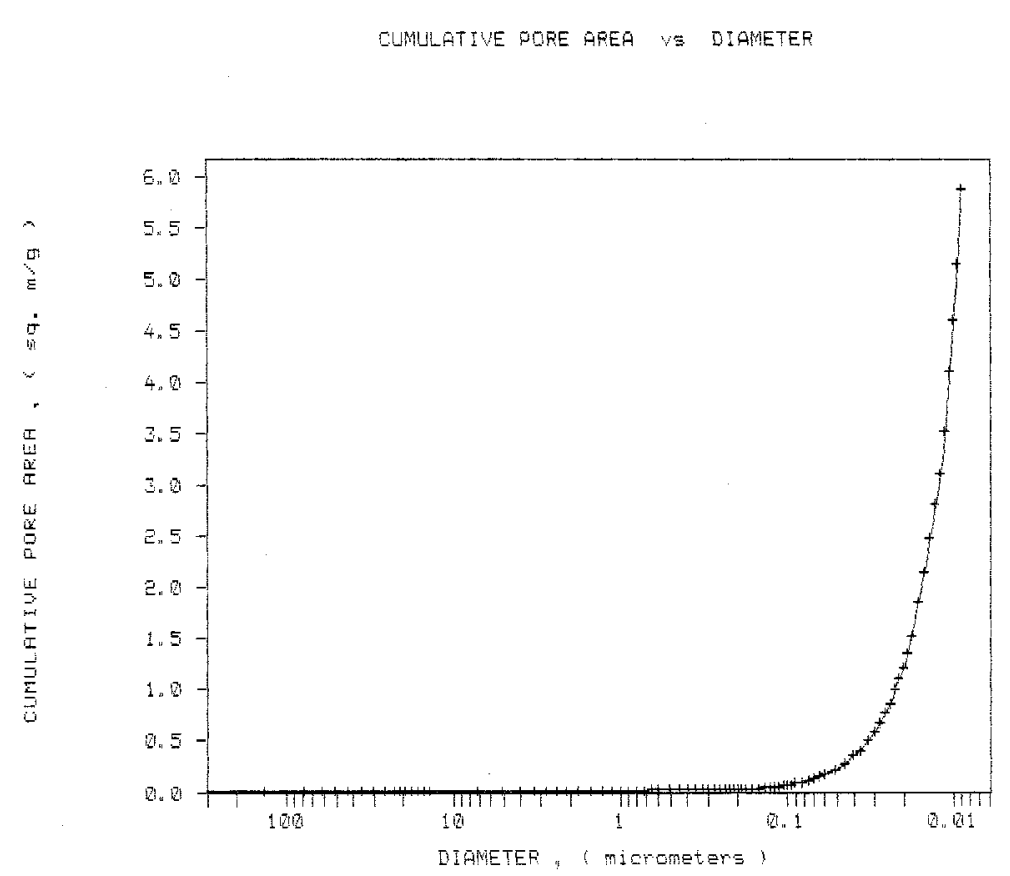

3 PORESIZER 9320 V2.0

PAGE 8

SAMPLE DIRECTORY/NUMBER: DATA2 /207

SAMPLE ID: \#16- \#30 (AMP 00 0114)

SAMPLE ID: \#16-
SUBMITTER: Sandra

Centro de Carac e Desenv. de Materiais - CCDM

LP $15: 03: 1704 / 22 / 00$

REP $15: 49: 07 \quad 04 / 22 / 00$

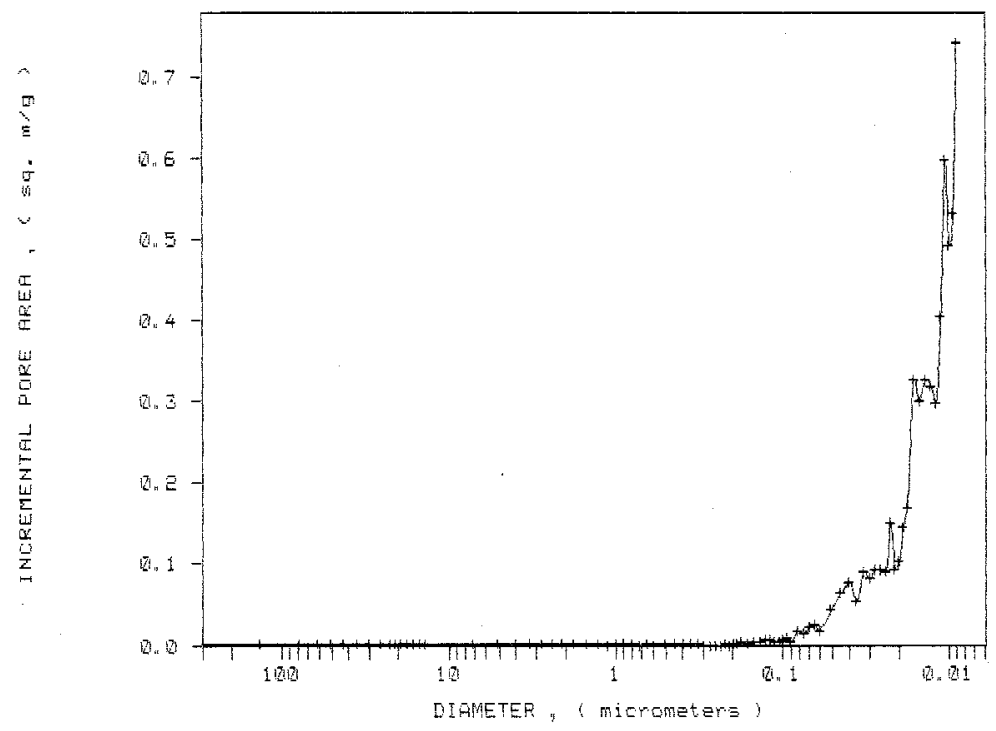


Ensaio de Porosimetria em Mercúrio - Borracha F (fração: \#50 - \#100)

-

PORESIZER $9320 \mathrm{~V} 2.04$

Centro de Carac. e Desenv. de Materiais - CCDM

PAGE 1

SAMPLE DIRECTORY/NUMBER: $2001 / 8$

SAMPLE ID: \#50-\#100 (AMP 000533 )

P $15: 13: 25 \quad 11 / 20 / 00$

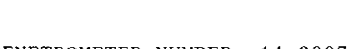

PENETROMETER NUMBER: $14-0097$
PENETROMETER CONSTANT: $10.79 \mu \mathrm{L} / \mathrm{p}$ STEM VOLUME: $\quad \begin{array}{lll}69.4440 \mathrm{~g} \\ \text { PETS }\end{array}$

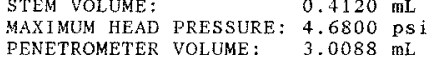

ADVANCING CONTACT ANGLE: $130.0 \mathrm{deg}$
RECEDING CONTACT ANGLE: $130.0 \mathrm{deg}$ MERCURY SURFACE TENSION: $\begin{array}{lr}\text { SARORY DENGITY: } & 13.5369 \mathrm{~g} / \\ \text { SAMPE WEIGT: } & 0.3280 \mathrm{~g} \\ \text { SAMPLE+PEN+Hg WEIGHT: } & 103.9670 \mathrm{~g}\end{array}$

LOW PRESSURE:

MERCURY FILLING PRESSURE: 0.6598 psia

HIGH PRESSURE:

$$
\begin{array}{ll}
\text { RUN TYPE: } & \text { AUTOMATIC } \\
\text { RUN METHOD: } & \text { EQUILIBATED } \\
\text { EQULILRATION TIME: } & 10 \text { Seconds } \\
\text { MAXIMUM INTRUS ION VOLLME: } & 0.0500 \mathrm{~mL} / \mathrm{g}
\end{array}
$$

INTRUSION DATA SUMMAR

TOTAL INTRUSION VOLUME $=1.0146 \mathrm{~mL} / \mathrm{g}$ $\begin{aligned} \text { TOTAL PORE AREA } & =13.505 \mathrm{sq} \\ \text { MEDIAN PORE DIAMETR (VOLME) } & =61.1311 \mu \mathrm{m} \\ \text { MEDIAN PORE DIAMETER (AREA) } & =0.0089 \mathrm{~mm}\end{aligned}$ MEDIAN PORE DIAMETER (AREA) $=0.0089 \mathrm{~mm}$
AVERAGE PORE DIAMETER $(4 V / A)=0.3005 \mathrm{~mm}$

$\begin{aligned} \text { BULK DENSITY } & 0.6795 \mathrm{~g} / \mathrm{mL} \\ \text { APPARENT (SKELETAL) DENSITY } & 2.1872 \mathrm{~g} / \mathrm{mL} \\ \text { POROSITY } & 68.94 \%\end{aligned}$
Centro de Carac. e Desenv. de Materiais - CCDM

PORESIZER $9320 \quad \mathrm{~V} 2.04$

PAGE $\quad 2$

SAMPLE DIRECTORY/NUMBER: $2001 / 8$

SAMPLE ID: $\$ 50-\# 100$ (AMP 000533 )

\begin{tabular}{|c|c|c|c|c|c|}
\hline $\begin{array}{c}\text { PORE } \\
\text { DIAMETER } \\
\text { MMM }\end{array}$ & $\begin{array}{c}\text { CUMULATIVE } \\
\text { VOLUME } \\
\mathrm{mL} / \mathrm{g}\end{array}$ & $\begin{array}{c}\text { INCREMENTAL } \\
\text { VoLUME } \\
\mathrm{mL} / \mathrm{g}\end{array}$ & $\begin{array}{l}\text { DIFFEREN. } \\
\mathrm{WOL} d V / \mathrm{dD} \\
\mathrm{mL} / \mathrm{g}-\mu \mathrm{m}\end{array}$ & $\begin{array}{c}\text { LOG DIFF. } \\
\text { VOL } \underset{\mathrm{dVL} / \mathrm{d} \log \mathrm{Og}}{\mathrm{mL} / \mathrm{g}}\end{array}$ & $\begin{array}{c}\text { PRESSURE } \\
\text { psia }\end{array}$ \\
\hline 274.1043 & 0.0000 & 0.0000 & $4.367 \mathrm{E}-04$ & $2.816 \mathrm{E}-01$ & 0.66 \\
\hline .0 & 0353 & & 2.1 & 1707 & 39 \\
\hline .28 & $\begin{array}{l}0.3531 \\
0.6347\end{array}$ & $\begin{array}{l}0.2459 \\
0.2816\end{array}$ & $\begin{array}{l}9.8 \\
1.14\end{array}$ & $\begin{array}{l}1.749 \mathrm{E}+00 \\
1.409 \mathrm{E}+00\end{array}$ & $\begin{array}{l}2.39 \\
3.46\end{array}$ \\
\hline & 0.7346 & 0.0999 & $\begin{array}{l}1.146 \mathrm{E}-02 \\
8.683 \mathrm{E}-03\end{array}$ & $8.610 E-01$ & \\
\hline & 0.8005 & 0.0659 & $7.018 \mathrm{E}-03$ & $5.608 \mathrm{E}-01$ & \\
\hline 1.0 & 0.8407 & 0.0402 & $6.278 \mathrm{E}-03$ & 4.091E-01 & \\
\hline 4.54 & 0.8608 & 0.0201 & $6.207 \mathrm{E}-03$ & 3. $585 \mathrm{E}-01$ & \\
\hline .96 & 0.87 & & & $3.170 \mathrm{E}-01$ & \\
\hline & $\begin{array}{l}0.8926 \\
0.9020\end{array}$ & $\begin{array}{l}0.0158 \\
0.0094\end{array}$ & $\begin{array}{l}5.39 \\
5.91\end{array}$ & $\begin{array}{l}2.746 \mathrm{E}-01 \\
2.484 \mathrm{E}-01\end{array}$ & \\
\hline 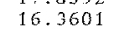 & . & 0.0090 & & $\begin{array}{l}\frac{2.4841}{2} 2.2991 \\
\end{array}$ & \\
\hline & & & 4.8 & $1.719 \mathrm{E}-01$ & \\
\hline & & & & & \\
\hline 11.74 & 0.9265 & & E- 04 & 1.4 & \\
\hline 8.9 & $\begin{array}{l}80 \\
45\end{array}$ & & & & 25 \\
\hline 6.00 & 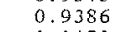 & 0 & 4.3 & 6.5 & \\
\hline & & & & & \\
\hline $\begin{array}{l}2.9595 \\
2.0076\end{array}$ & $\begin{array}{l}0.9575 \\
0.9637\end{array}$ & $\begin{array}{l}0.0096 \\
0.0062\end{array}$ & $\begin{array}{l}6.389 \mathrm{E}-03 \\
5.838 \mathrm{E}-03\end{array}$ & & 90.0 \\
\hline 1.4897 & 0.9666 & 0.0029 & $5.475 E-03$ & $1.919 \mathrm{E}-02$ & 121.4 \\
\hline $\begin{array}{l}1.0 \\
0.6\end{array}$ & 9712 & & $\begin{array}{l}5.7 \\
3.96\end{array}$ & & 270.90 \\
\hline 0.5 & 0.9716 & 0 & & & 320 \\
\hline & & & & & \\
\hline $\begin{array}{l}0 . \\
0 .\end{array}$ & & & $\begin{array}{l}3.9 \\
5.5 \\
5\end{array}$ & & $\begin{array}{l}638.22 \\
799.06\end{array}$ \\
\hline 0. & & & & & 1001.89 \\
\hline & & & & & 1999.22 \\
\hline & 0 & 6 & & & \\
\hline 0.0 & & & & & 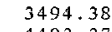 \\
\hline 0.0 & & & & & 4493. \\
\hline & & & & & \\
\hline & & & & & 5 \\
\hline & & & & & \\
\hline & & & & & 185 \\
\hline & & & & & $\begin{array}{l}14916 \\
17972\end{array}$ \\
\hline 0 & 1.00 & & 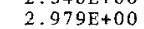 & 6.345 & 19973 \\
\hline & & & & & \\
\hline & & & & & \\
\hline
\end{tabular}

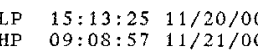

REP 09:13:02 11/21/00 
Ensaio de Porosimetria em Mercúrio - Borracha F (fração: \#50 - \#100) - continuação

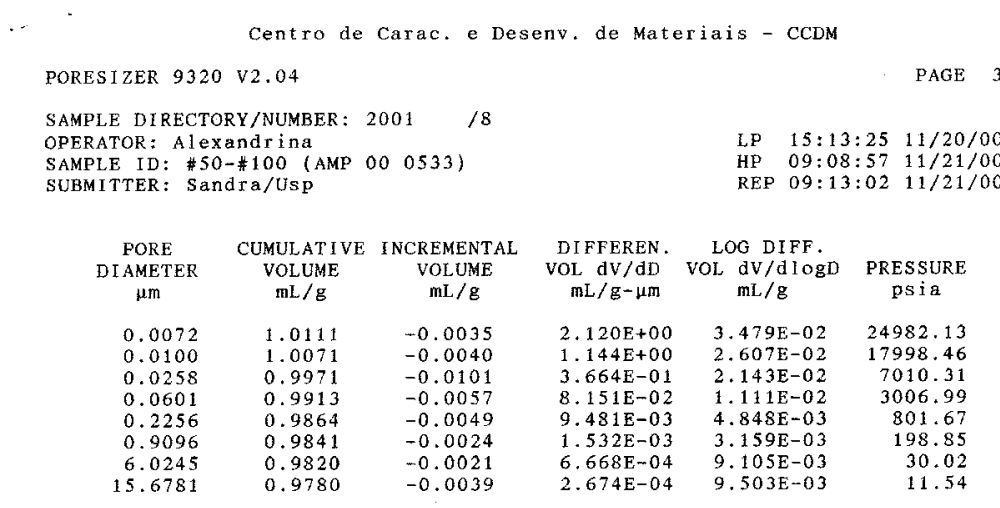

\begin{tabular}{|c|c|c|}
\hline ZER $9320 \quad \mathrm{~V} 2.04$ & & PAGE \\
\hline $\begin{array}{l}\text { AMPLE DIRECTORY/NUMBER: } 2001 \\
\text { PERATOR: Alexandrina } \\
\text { AMLE ID: \#50-\#100 (AMP } 000533 \text { ) } \\
\text { UBMITTER: Sandra/Usp }\end{array}$ & $\begin{array}{ll}\text { LP } & 15: 13: 25 \\
\text { HP } & 09: 08 ; 57 \\
\text { REP } & 09: 13: 02\end{array}$ & $\begin{array}{l}11 / 20 / 00 \\
11 / 21 / 00 \\
11 / 21 / 00\end{array}$ \\
\hline
\end{tabular}

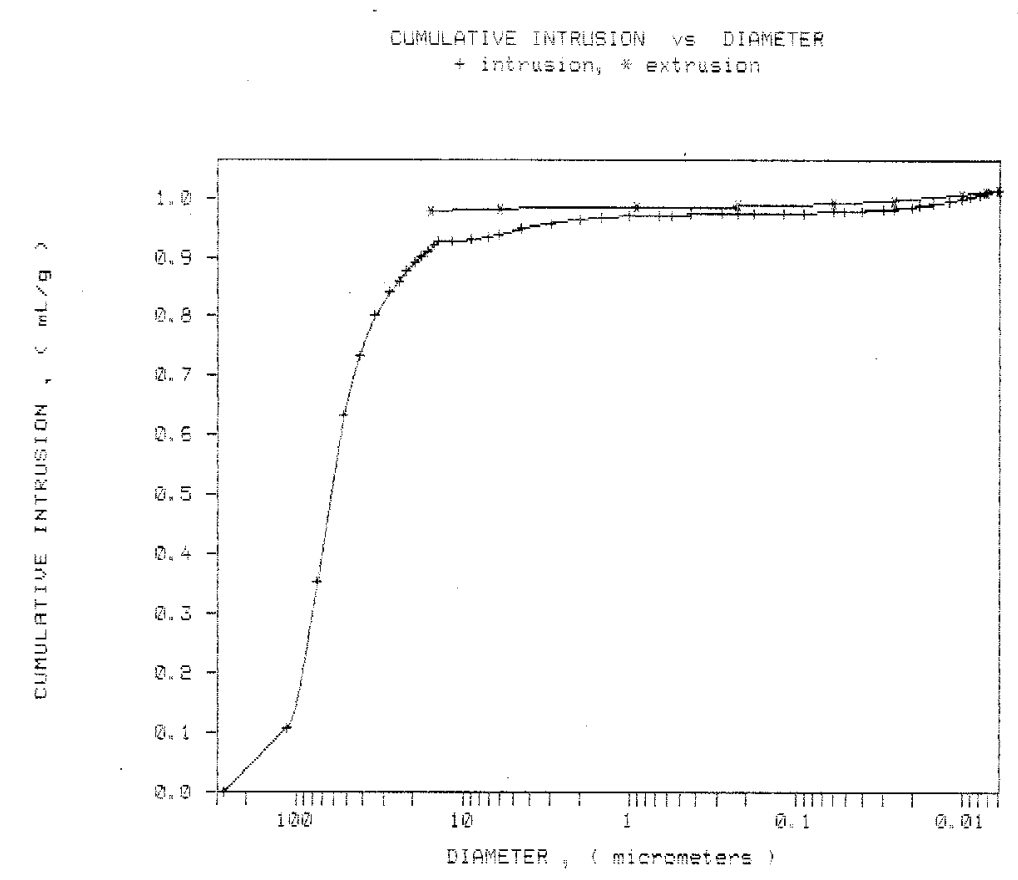


Ensaio de Porosimetria em Mercúrio - Borracha F (fração: \#50 - \#100) - continuação

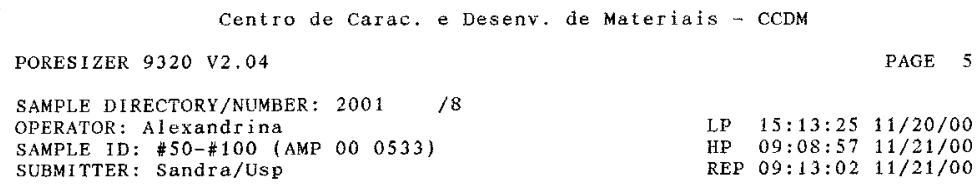

PAGE 5

SAMPLE DIRECTORY/NUMBER: 2001

SAMPLE ID: $\# 50-\# 100$ (AMP 00 0533)

LP $15: 13: 25 \quad 11 / 20 / 00$

REP $09: 13: 02 \quad 11 / 21 / 00$

THREMENTEL INTELEION YE DIAMETER

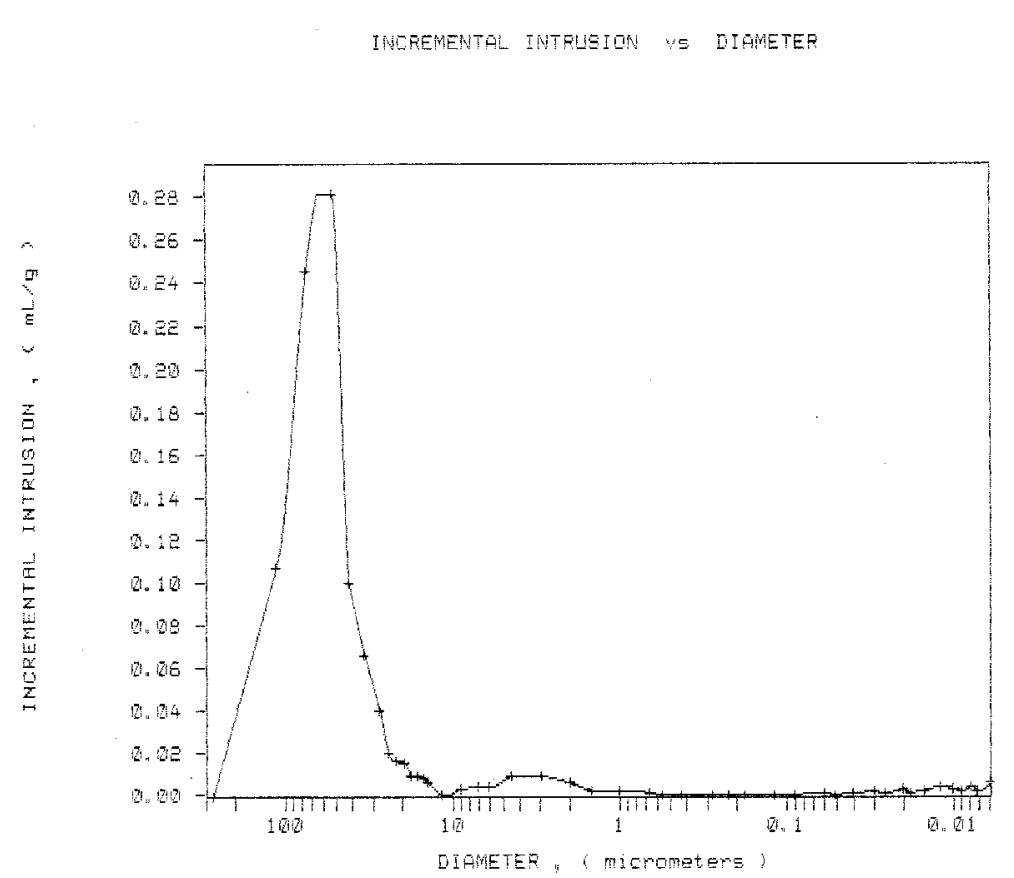

Centro de Carac, e Desenv, de Materiais - CCDM

PORESI ZER 9320 V2.04

PAGE 6

SAMPLE DIRECTORY/NUMBER: $2001 / 8$

SAMPTF ID: 50 - 100 (AMP 000533 )

SUBMITTER: Sandra/Us

LP $15: 13: 25 \quad 11 / 20 / 00$

REP 09:13:02 11/21/00

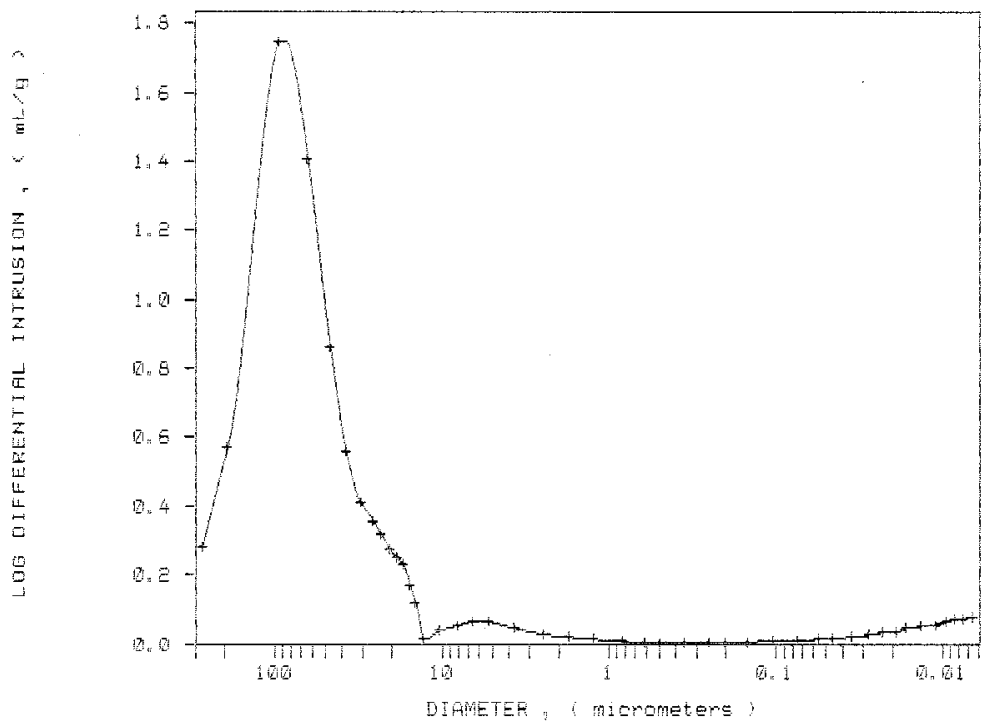


Ensaio de Porosimetria em Mercúrio - Borracha F (fração: \#50 - \#100) - continuação

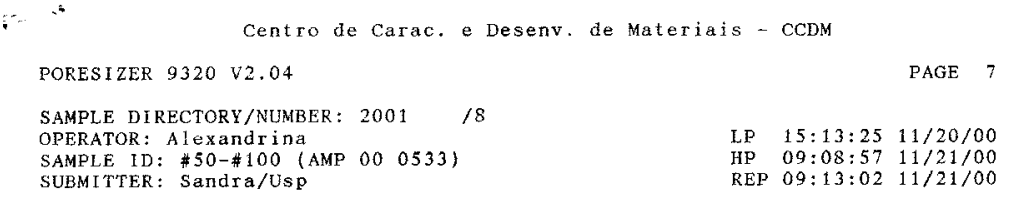

PAGE ?

LP $\quad 15: 13: 25 \quad 11 / 20 / 00$

HP $09: 08: 57 \quad 11 / 21 / 000$

DUMULATIUE FORE HFEA YE DIRTETEF

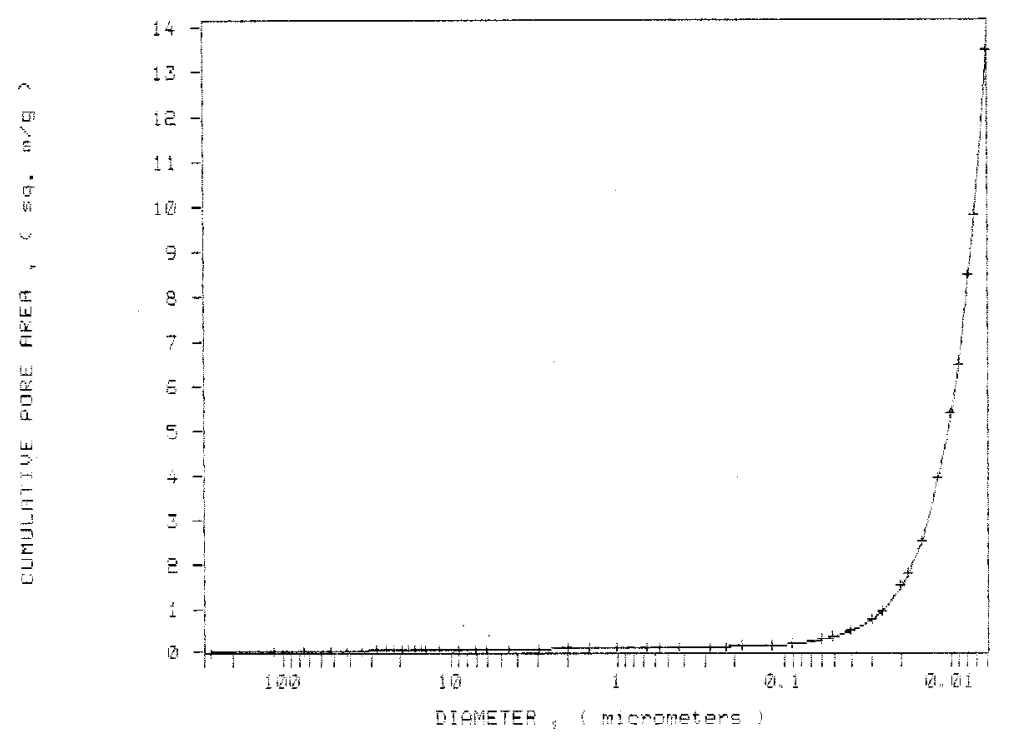

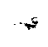
REP $09: 13: 02 \quad 11 / 21 / 0$ 
Análise Termogravimétrica - Borracha F (fração: \#50 - \#100)

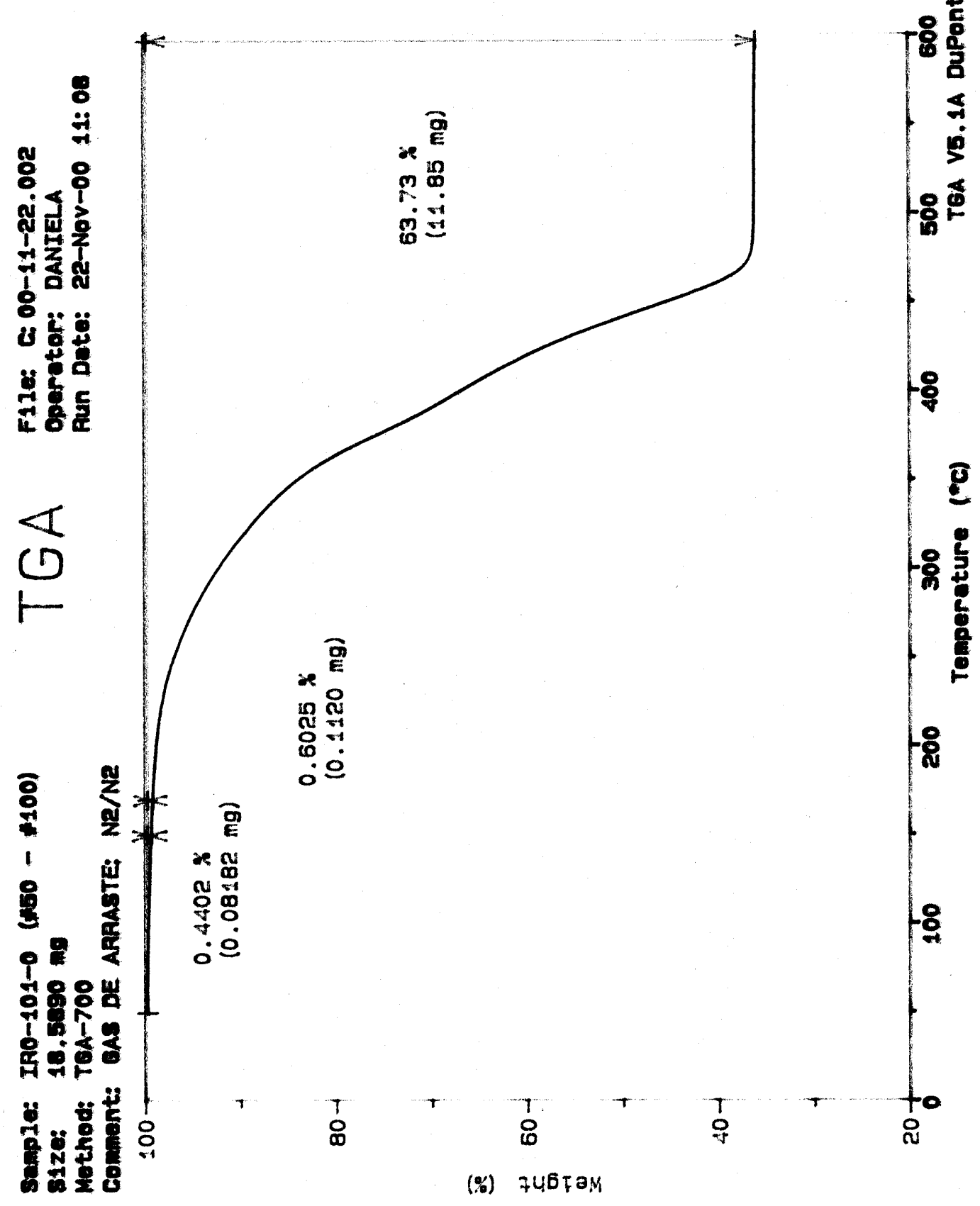


Análise Termogravimétrica - Borracha G (fração: 3/8” - \#4)

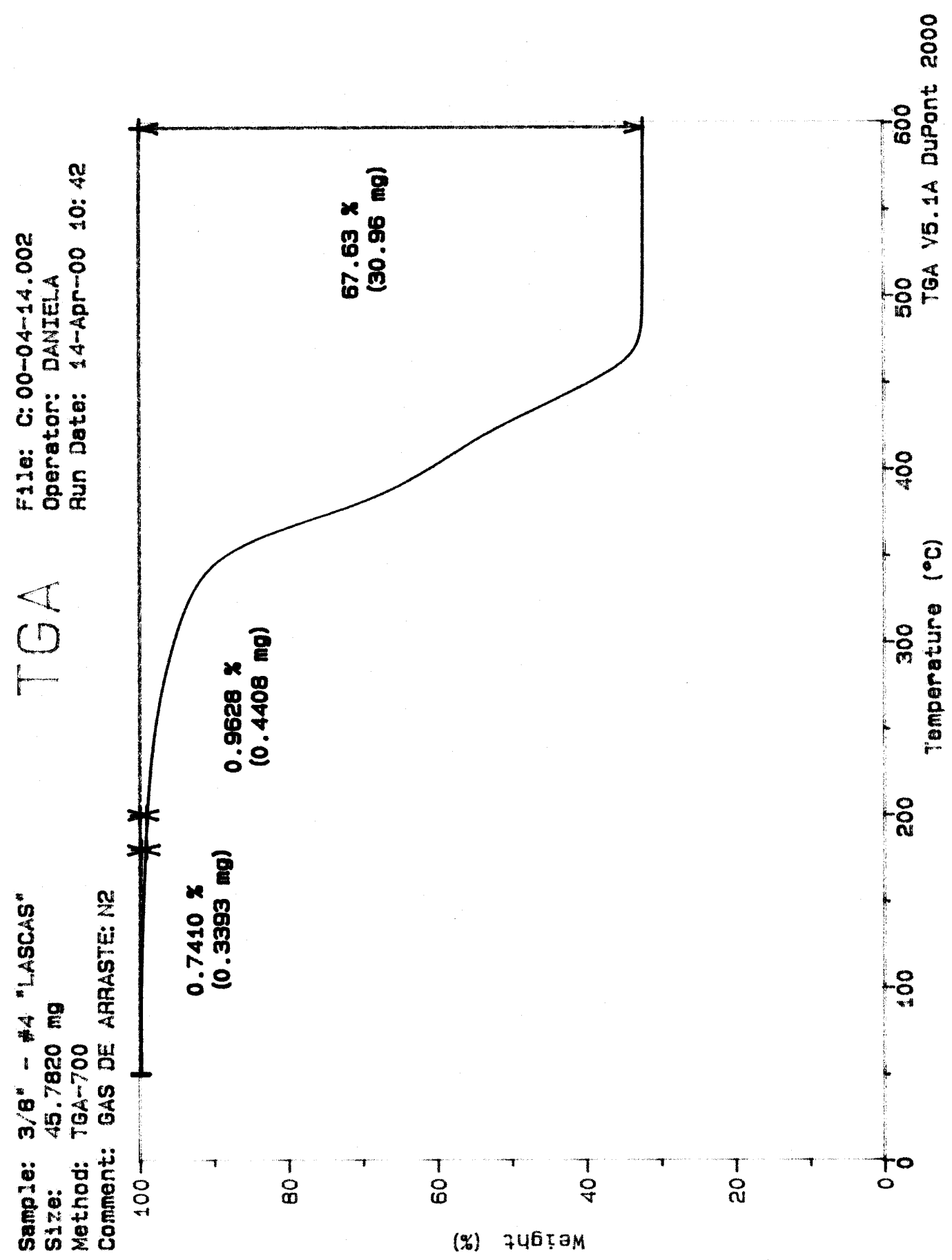


Análise Termogravimétrica - Borracha G (fração: \#16 - \#30)

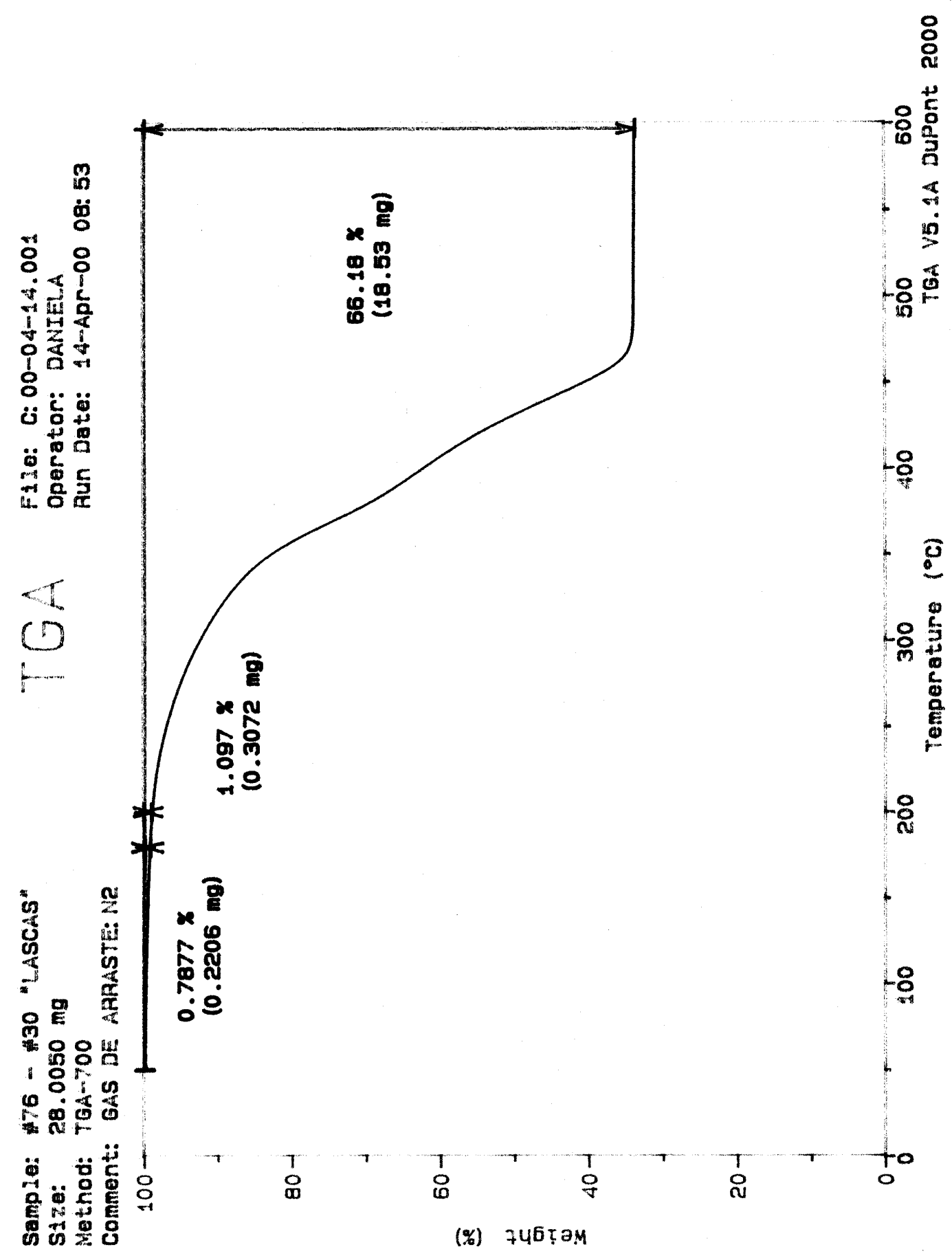


Resultados dos Ensaios de Trilha de Roda em Equipamento Simulador de Tráfego tipo LCPC 
ESCOL A POUTÉCCNICA DA UNIVERSIDADE DE SÃO PAULO DEPARTAMENTO DE ENGENHARIA DE TRANSPORTES

Laboratónio de Tecnologia de Pavimentação

Identificação:

Temperatura do Ensaio:
Mistura de Controle - 6,2\% Cap-20

$60^{\circ} \mathrm{C}$
LADO A - Placa 448

Ciclos: 0
\begin{tabular}{|c|c|c|c|c|c|}
\hline & 1 & 2 & 3 & 4 & 5 \\
\hline A & 1315 & 1368 & 1484 & 1420 & 1310 \\
\hline B & 947 & 1117 & 1195 & 1166 & 1008 \\
\hline C & 1274 & 1367 & 1405 & 1344 & 1362 \\
\hline
\end{tabular}

Ciclos: 100
\begin{tabular}{|c|c|c|c|c|c|}
\hline & 1 & 2 & 3 & 4 & 5 \\
\hline A & 1471 & 1548 & 1642 & 1624 & 1502 \\
\hline B & 1149 & 1315 & 1379 & 1295 & 1171 \\
\hline C & 1402 & 1552 & 1544 & 1505 & 1511 \\
\hline
\end{tabular}

Ciclos: 300

\begin{tabular}{|c|c|c|c|c|c|}
\hline & 1 & 2 & 3 & 4 & 5 \\
\hline A & 1545 & 1600 & 1689 & 1675 & 1553 \\
\hline B & 1215 & 1373 & 1420 & 1355 & 1213 \\
\hline C & 1443 & 1600 & 1578 & 1542 & 1548 \\
\hline
\end{tabular}

Ciclos: 1000

\begin{tabular}{|c|c|c|c|c|c|}
\hline & 1 & 2 & 3 & 4 & 5 \\
\hline A & 1642 & 1658 & 1750 & 1738 & 1630 \\
\hline B & 1300 & 1441 & 1483 & 1419 & 1280 \\
\hline C & 1507 & 1665 & 1627 & 1593 & 1633 \\
\hline
\end{tabular}

Ciclos: 3000

\begin{tabular}{|c|c|c|c|c|c|}
\hline & 1 & 2 & 3 & 4 & 5 \\
\hline A & 1719 & 1740 & 1809 & 1810 & 1696 \\
\hline B & 1387 & 1507 & 1525 & 1502 & 1357 \\
\hline C & 1583 & 1741 & 1680 & 1655 & 1706 \\
\hline
\end{tabular}

Ciclos: 10000

\begin{tabular}{|c|c|c|c|c|c|}
\hline & 1 & 2 & 3 & 4 & 5 \\
\hline A & 1798 & 1832 & 1880 & 1893 & 1759 \\
\hline B & 1477 & 1596 & 1637 & 1585 & 1439 \\
\hline C & 1656 & 1828 & 1754 & 1718 & 1766 \\
\hline
\end{tabular}

Ciclos: 30000

Ciclos: 30000
\begin{tabular}{|c|c|c|c|c|c|}
\hline & 1 & 2 & 3 & 4 & 5 \\
\hline A & 1867 & 1904 & 1928 & 1954 & 1814 \\
\hline B & 1542 & 1662 & 1700 & 1646 & 1496 \\
\hline C & 1717 & 1892 & 1805 & 1770 & 1816 \\
\hline
\end{tabular}

LADO B - Placa 449

Ciclos: 0
\begin{tabular}{|c|c|c|c|c|c|}
\hline & 1 & 2 & 3 & 4 & 5 \\
\hline A & 1449 & 1635 & 1789 & 1463 & 1481 \\
\hline B & 1044 & 1299 & 1290 & 1086 & 1093 \\
\hline C & 1323 & 1559 & 1436 & 1472 & 1423 \\
\hline
\end{tabular}

Ciclos: 100
\begin{tabular}{|c|c|c|c|c|c|}
\hline & 1 & 2 & 3 & 4 & 5 \\
\hline A & 1605 & 1800 & 1905 & 1661 & 1661 \\
\hline B & 1176 & 1462 & 1429 & 1252 & 1254 \\
\hline C & 1446 & 1678 & 1581 & 1600 & 1552 \\
\hline
\end{tabular}

Ciclos: 300

\begin{tabular}{|c|c|c|c|c|c|}
\hline & 1 & 2 & 3 & 4 & 5 \\
\hline A & 1648 & 1835 & 1937 & 1671 & 1704 \\
\hline B & 1205 & 1495 & 1461 & 1291 & 1289 \\
\hline C & 1487 & 1710 & 1616 & 1643 & 1600 \\
\hline
\end{tabular}

Ciclos: 1000
\begin{tabular}{|c|c|c|c|c|c|}
\hline & 1 & 2 & 3 & 4 & 5 \\
\hline A & 1700 & 1877 & 1979 & 1708 & 1757 \\
\hline B & 1261 & 1553 & 1505 & 1325 & 1330 \\
\hline C & 1544 & 1747 & 1653 & 1675 & 1629 \\
\hline
\end{tabular}

Ciclos: 3000
\begin{tabular}{|c|c|c|c|c|c|}
\hline & 1 & 2 & 3 & 4 & 5 \\
\hline A & 1752 & 1920 & 2019 & 1758 & 1803 \\
\hline B & 1306 & 1600 & 1548 & 1370 & 1388 \\
\hline C & 1605 & 1789 & 1693 & 1725 & 1663 \\
\hline
\end{tabular}

Ciclos: 10000
\begin{tabular}{|c|c|c|c|c|c|}
\hline & 1 & 2 & 3 & 4 & 5 \\
\hline A & 1813 & 1971 & 2068 & 1824 & 1853 \\
\hline B & 1378 & 1656 & 1613 & 1437 & 1421 \\
\hline C & 1663 & 1844 & 1753 & 1785 & 1745 \\
\hline
\end{tabular}

Ciclos: 30000
\begin{tabular}{|c|c|c|c|c|c|}
\hline & 1 & 2 & 3 & 4 & 5 \\
\hline A & 1862 & 2015 & 2103 & 1875 & 1912 \\
\hline B & 1423 & 1705 & 1669 & 1489 & 1484 \\
\hline C & 1705 & 1881 & 1793 & 1825 & 1787 \\
\hline
\end{tabular}




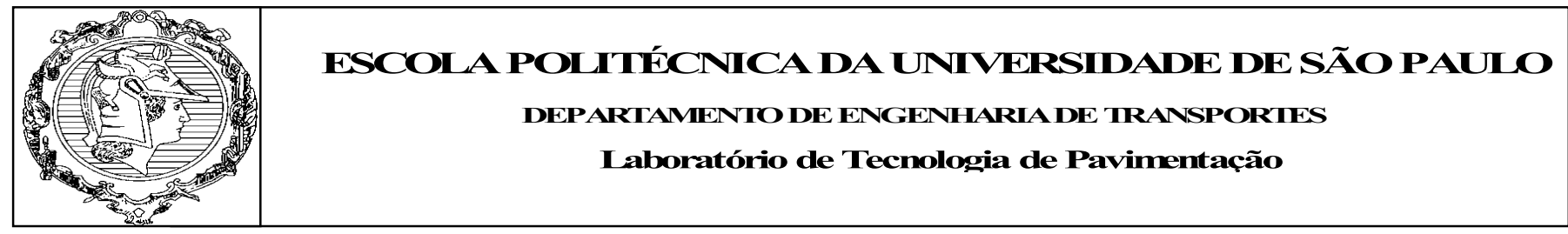

Mistura de Controle - 6,2\% Cap-20

$$
\mathrm{T}=60^{\circ} \mathrm{C}
$$

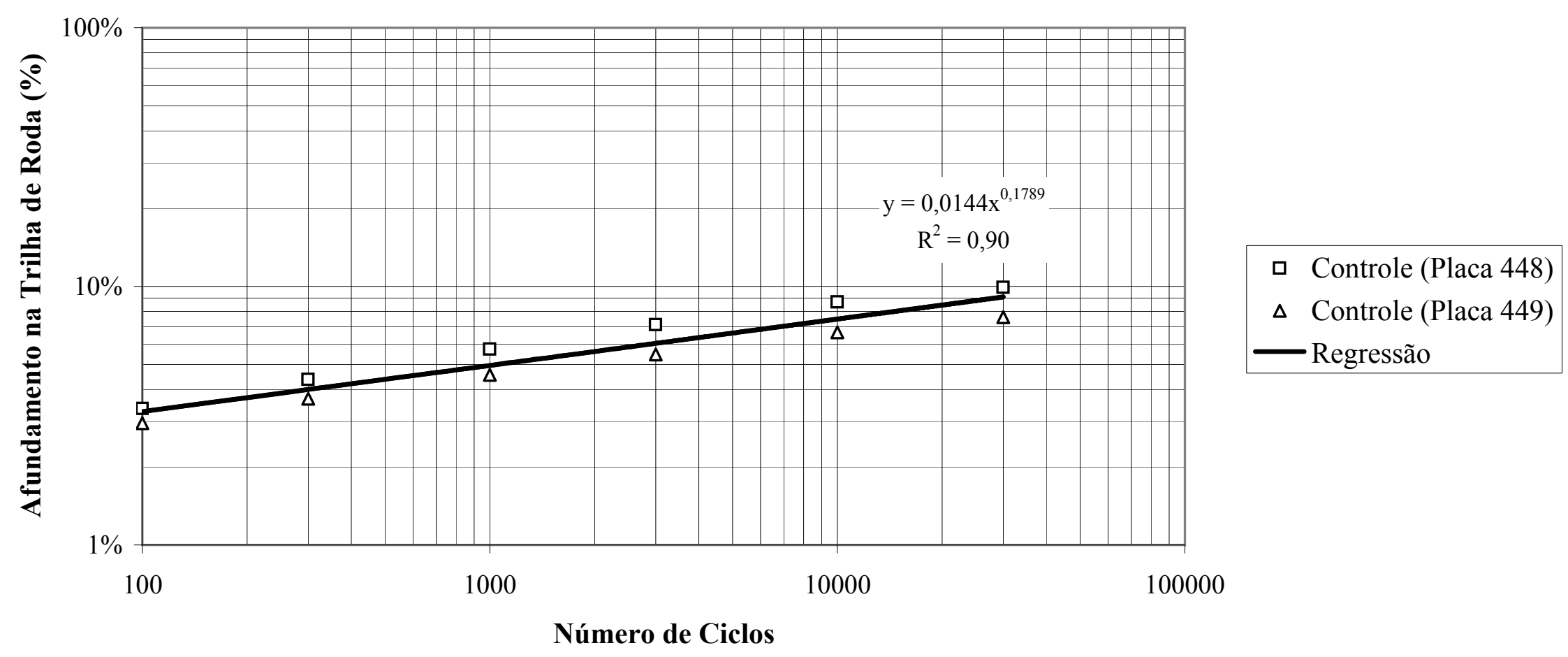


ESCOLA POL ITÉCNICA DA UNIVERSIDADE DE SÃO PAULO DEPARTAMENTO DE ENGENHARIA DE TRANSPORTES

Laboratónio de Tecnologia de Pavimentação

Identificação:

Temperatura do Ensaio:
Mistura 2G' - 7,3\% Cap-20

$60^{\circ} \mathrm{C}$
LADO A - Placa 452

Ciclos: 0

\begin{tabular}{|c|c|c|c|c|c|}
\hline & 1 & 2 & 3 & 4 & 5 \\
\hline A & 1481 & 1352 & 1113 & 1180 & 1005 \\
\hline B & 1053 & 910 & 825 & 690 & 668 \\
\hline C & 1473 & 1489 & 1190 & 1214 & 1182 \\
\hline
\end{tabular}

Ciclos: 100
\begin{tabular}{|c|c|c|c|c|c|}
\hline & 1 & 2 & 3 & 4 & 5 \\
\hline A & 1753 & 1635 & 1350 & 1370 & 1245 \\
\hline B & 1350 & 1305 & 1081 & 985 & 971 \\
\hline C & 1700 & 1714 & 1448 & 1372 & 1395 \\
\hline
\end{tabular}

Ciclos: 300

\begin{tabular}{|c|c|c|c|c|c|}
\hline & 1 & 2 & 3 & 4 & 5 \\
\hline A & 1842 & 1731 & 1466 & 1510 & 1349 \\
\hline B & 1416 & 1427 & 1192 & 1085 & 1095 \\
\hline C & 1762 & 1780 & 1550 & 1430 & 1430 \\
\hline
\end{tabular}

Ciclos: 1000

\begin{tabular}{l} 
Ciclos: 1000 \\
\hline
\end{tabular}

Ciclos: 3000

\begin{tabular}{|c|c|c|c|c|c|}
\hline & 1 & 2 & 3 & 4 & 5 \\
\hline A & 2201 & 2256 & 2073 & 2028 & 2055 \\
\hline B & 1824 & 2100 & 1846 & 1818 & 1865 \\
\hline C & 2086 & 2208 & 2012 & 1961 & 1970 \\
\hline
\end{tabular}

Ciclos: 10000

\begin{tabular}{|c|c|c|c|c|c|}
\hline & 1 & 2 & 3 & 4 & 5 \\
\hline $\mathrm{A}$ & & & & & \\
\hline $\mathrm{B}$ & & & & & \\
\hline $\mathrm{C}$ & & & & & \\
\hline
\end{tabular}

Ciclos: 30000

\begin{tabular}{|c|c|c|c|c|c|}
\hline & 1 & 2 & 3 & 4 & 5 \\
\hline $\mathrm{A}$ & & & & & \\
\hline $\mathrm{B}$ & & & & & \\
\hline $\mathrm{C}$ & & & & & \\
\hline
\end{tabular}

LADO B - Placa 453

Ciclos: 0
\begin{tabular}{|c|c|c|c|c|c|}
\hline & 1 & 2 & 3 & 4 & 5 \\
\hline A & 1589 & 1548 & 1442 & 1415 & 1270 \\
\hline B & 1226 & 1150 & 1136 & 1131 & 898 \\
\hline C & 1570 & 1532 & 1464 & 1446 & 1308 \\
\hline
\end{tabular}

Ciclos: 100

\begin{tabular}{|c|c|c|c|c|c|}
\hline & 1 & 2 & 3 & 4 & 5 \\
\hline A & 1825 & 1730 & 1722 & 1776 & 1578 \\
\hline B & 1531 & 1444 & 1523 & 1433 & 1230 \\
\hline C & 1725 & 1753 & 1755 & 1681 & 1539 \\
\hline
\end{tabular}

Ciclos: 300

\begin{tabular}{|c|c|c|c|c|c|}
\hline & 1 & 2 & 3 & 4 & 5 \\
\hline A & 1988 & 1897 & 1880 & 1950 & 1780 \\
\hline B & 1678 & 1581 & 1677 & 1574 & 1415 \\
\hline C & 1856 & 1865 & 1868 & 1810 & 1674 \\
\hline
\end{tabular}

Ciclos: 1000

\begin{tabular}{|c|c|c|c|c|c|}
\hline & 1 & 2 & 3 & 4 & 5 \\
\hline A & 2142 & 1998 & 2052 & 2124 & 2002 \\
\hline B & 1822 & 1761 & 1835 & 1741 & 1636 \\
\hline C & 1991 & 2012 & 1982 & 1936 & 1840 \\
\hline
\end{tabular}

Ciclos: 3000

\begin{tabular}{|c|c|c|c|c|c|}
\hline & 1 & 2 & 3 & 4 & 5 \\
\hline A & 2670 & 2777 & 2718 & 2932 & 2701 \\
\hline B & 2403 & 2259 & 2560 & 2772 & 2423 \\
\hline C & 2410 & 2640 & 2605 & 2644 & 2502 \\
\hline
\end{tabular}

Ciclos: 10000

\begin{tabular}{|l|l|l|l|l|l|}
\hline & 1 & 2 & 3 & 4 & 5 \\
\hline $\mathrm{A}$ & & & & & \\
\hline $\mathrm{B}$ & & & & & \\
\hline $\mathrm{C}$ & & & & & \\
\hline
\end{tabular}

Ciclos: 30000

\begin{tabular}{|l|l|l|l|l|l|}
\hline & 1 & 2 & 3 & 4 & 5 \\
\hline $\mathrm{A}$ & & & & & \\
\hline $\mathrm{B}$ & & & & & \\
\hline $\mathrm{C}$ & & & & & \\
\hline
\end{tabular}




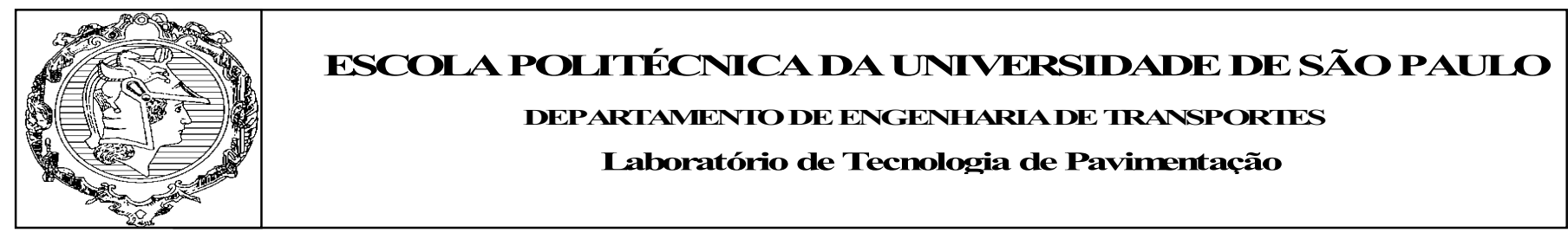

Mistura 2G' - 7,3\% Cap-20

$\mathrm{T}=60^{\circ} \mathrm{C}$

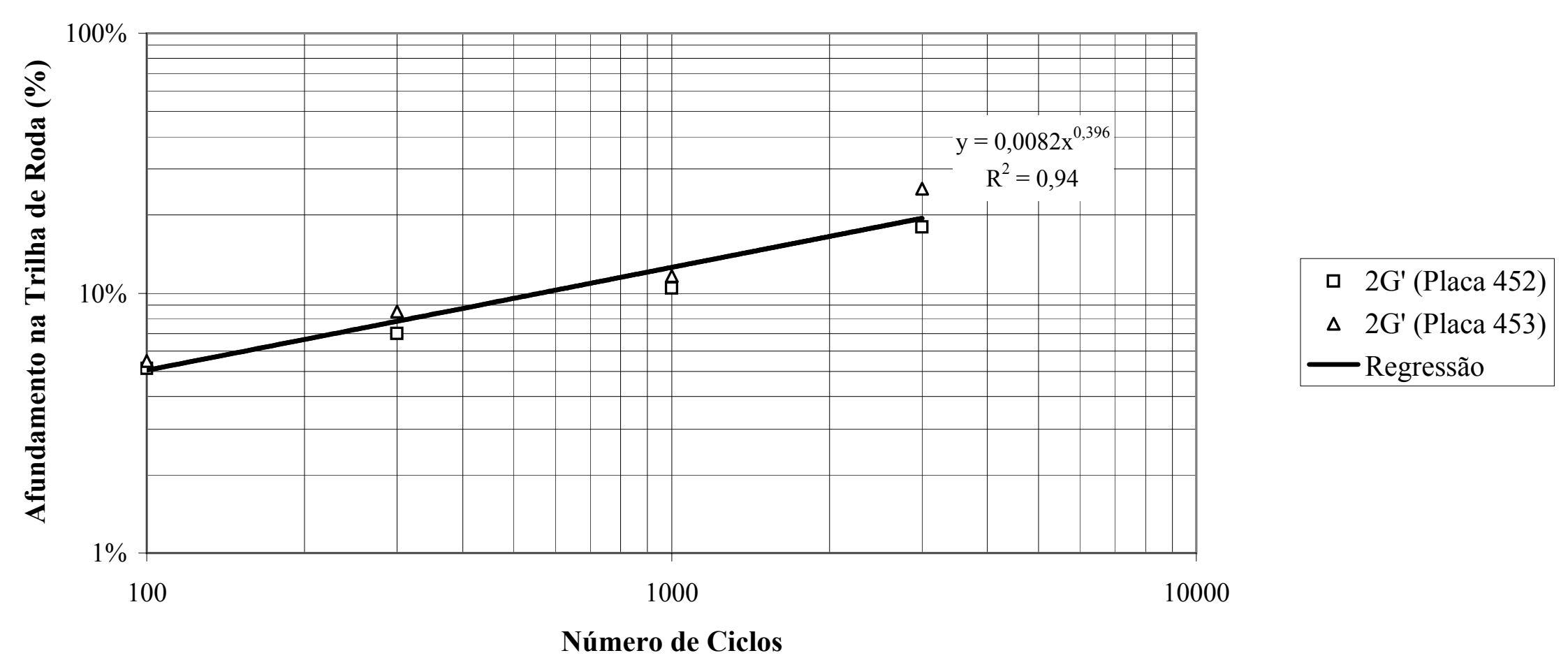


ESCOLA POLITÉCNICA DA UNIVERSIDADE DE SÃO PAULO DEPARTAMENTO DE ENGENHARIA DE TRANSPORTES

Laboratónio de Tecnologia de Pavimentação

Identificação:

Temperatura do Ensaio:
Mistura 2F' - 7,8\% Cap-20

$60^{\circ} \mathrm{C}$
LADO A - Placa 450

Ciclos: 0

\begin{tabular}{|c|c|c|c|c|c|}
\hline & 1 & 2 & 3 & 4 & 5 \\
\hline A & 1770 & 1759 & 1746 & 1698 & 1711 \\
\hline B & 1500 & 1542 & 1486 & 1462 & 1371 \\
\hline C & 1749 & 1850 & 1770 & 1710 & 1680 \\
\hline
\end{tabular}

Ciclos: 100

\begin{tabular}{|c|c|c|c|c|c|}
\hline & 1 & 2 & 3 & 4 & 5 \\
\hline A & 1981 & 2018 & 1963 & 1938 & 1964 \\
\hline B & 1810 & 1823 & 1737 & 1765 & 1737 \\
\hline C & 1975 & 2074 & 1948 & 1703 & 1898 \\
\hline
\end{tabular}

Ciclos: 300

\begin{tabular}{|c|c|c|c|c|c|}
\hline & 1 & 2 & 3 & 4 & 5 \\
\hline A & 2219 & 2149 & 2124 & 2064 & 2124 \\
\hline B & 2083 & 1975 & 1900 & 1900 & 1921 \\
\hline C & 2216 & 2180 & 2103 & 2018 & 2023 \\
\hline
\end{tabular}

Ciclos: 1000

\begin{tabular}{|c|c|c|c|c|c|}
\hline & 1 & 2 & 3 & 4 & 5 \\
\hline A & 2466 & 2412 & 2357 & 2326 & 2439 \\
\hline B & 2365 & 2222 & 2116 & 2184 & 2225 \\
\hline C & 2494 & 2427 & 2352 & 2305 & 2410 \\
\hline
\end{tabular}

Ciclos: 3000

Ciclos: 3000
\begin{tabular}{|c|c|c|c|c|c|}
\hline & 1 & 2 & 3 & 4 & 5 \\
\hline A & 2713 & 2675 & 2590 & 2588 & 2754 \\
\hline B & 2647 & 2469 & 2332 & 2468 & 2529 \\
\hline C & 2772 & 2674 & 2601 & 2592 & 2797 \\
\hline
\end{tabular}

Ciclos: 10000

\begin{tabular}{|l|l|l|l|l|l|}
\hline & 1 & 2 & 3 & 4 & 5 \\
\hline A & & & & & \\
\hline B & & & & & \\
\hline C & & & & & \\
\hline
\end{tabular}

Ciclos: 30000

\begin{tabular}{l} 
Ciclos: 30000 \\
\hline
\end{tabular}

LADO B - Placa 451

Ciclos: 0

\begin{tabular}{|c|c|c|c|c|c|}
\hline & 1 & 2 & 3 & 4 & 5 \\
\hline A & 1681 & 1727 & 1900 & 1876 & 1618 \\
\hline B & 1282 & 1580 & 1767 & 1618 & 1300 \\
\hline C & 1636 & 1794 & 1737 & 1772 & 1546 \\
\hline
\end{tabular}

Ciclos: 100

\begin{tabular}{|c|c|c|c|c|c|}
\hline & 1 & 2 & 3 & 4 & 5 \\
\hline A & 1858 & 1953 & 2123 & 2120 & 1858 \\
\hline B & 1558 & 1787 & 1915 & 1818 & 1560 \\
\hline C & 1828 & 1968 & 1824 & 1966 & 1733 \\
\hline
\end{tabular}

Ciclos: 300
\begin{tabular}{|c|c|c|c|c|c|}
\hline & 1 & 2 & 3 & 4 & 5 \\
\hline A & 1956 & 2040 & 2232 & 2205 & 1987 \\
\hline B & 1669 & 1851 & 1970 & 1886 & 1667 \\
\hline C & 1925 & 2045 & 1876 & 2030 & 1847 \\
\hline
\end{tabular}

Ciclos: 1000

\begin{tabular}{|c|c|c|c|c|c|}
\hline & 1 & 2 & 3 & 4 & 5 \\
\hline A & 2237 & 2249 & 2374 & 2358 & 2206 \\
\hline B & 1906 & 1979 & 2085 & 2015 & 1865 \\
\hline C & 2116 & 2173 & 1973 & 2153 & 2005 \\
\hline
\end{tabular}

Ciclos: 3000
\begin{tabular}{|c|c|c|c|c|c|}
\hline & 1 & 2 & 3 & 4 & 5 \\
\hline A & 2510 & 2541 & 2649 & 2620 & 2467 \\
\hline B & 2194 & 2250 & 2303 & 2298 & 2132 \\
\hline C & 2352 & 2408 & 2400 & 2368 & 2222 \\
\hline
\end{tabular}

Ciclos: 10000

\begin{tabular}{|l|l|l|l|l|l|}
\hline & 1 & 2 & 3 & 4 & 5 \\
\hline A & & & & & \\
\hline B & & & & & \\
\hline C & & & & & \\
\hline
\end{tabular}

Ciclos: 30000

\begin{tabular}{|c|c|c|c|c|c|}
\hline & 1 & 2 & 3 & 4 & 5 \\
\hline A & & & & & \\
\hline B & & & & & \\
\hline C & & & & & \\
\hline
\end{tabular}




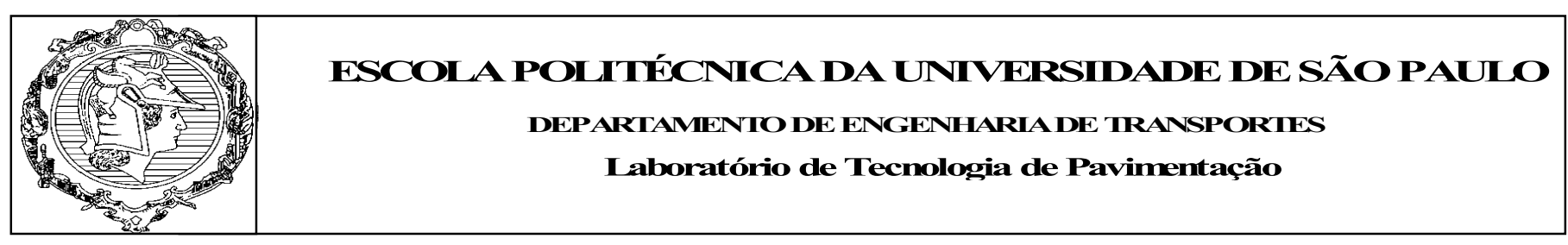

Mistura 2F' - 7,8\% Cap-20

$\mathrm{T}=60{ }^{\circ} \mathrm{C}$

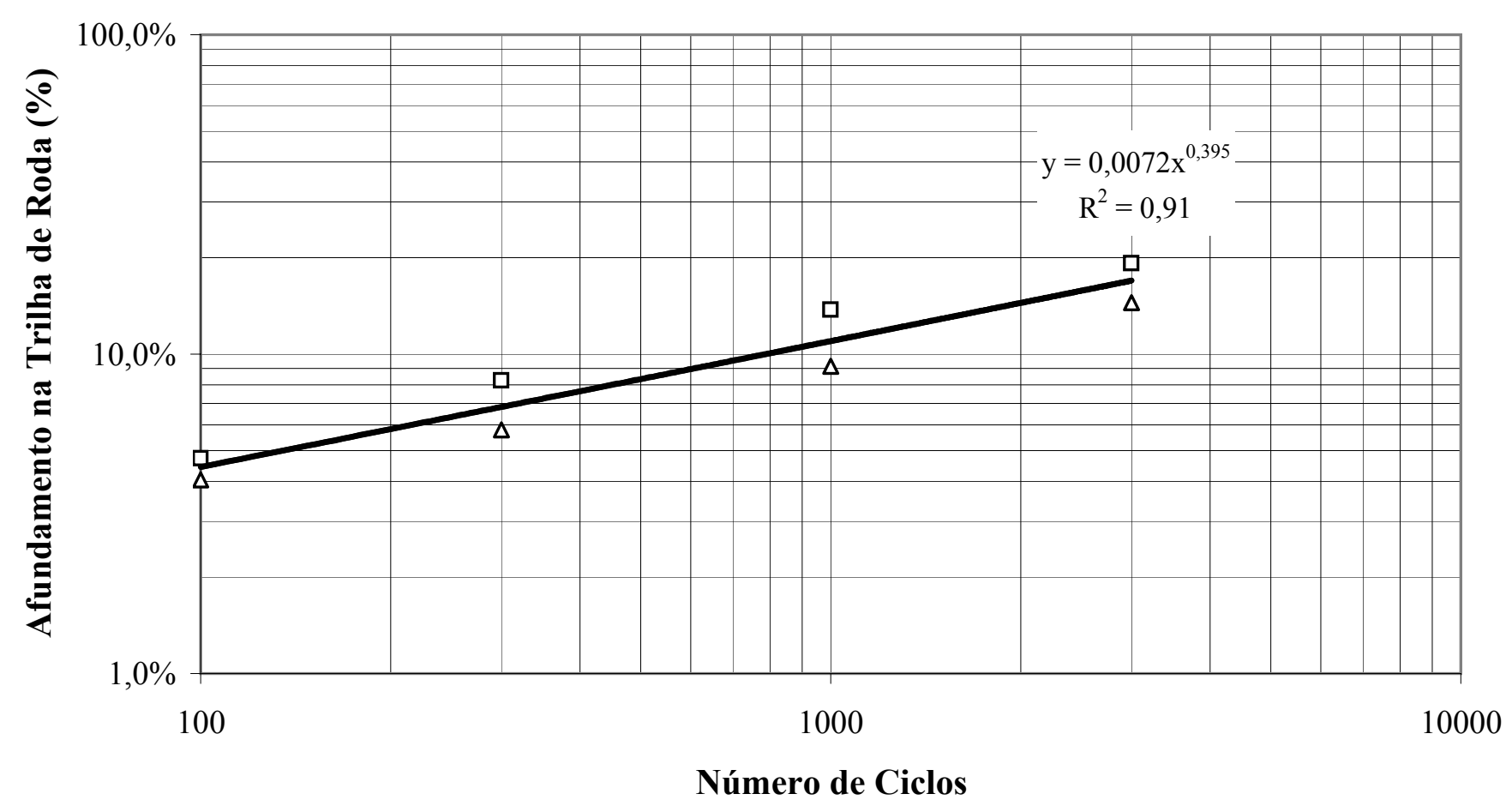

$2 F^{\prime}$ (Placa 450)

$\Delta \quad$ 2F' (Placa 451)

一 Regressão 
Identificação:

Temperatura do Ensaio:
Mistura 2G - 6,4\% Cap-20

$60^{\circ} \mathrm{C}$

\section{LADO A - Placa 461}

Ciclos: 0

\begin{tabular}{|c|c|c|c|c|c|}
\hline & 1 & 2 & 3 & 4 & 5 \\
\hline A & 1453 & 1615 & 1618 & 1566 & 1410 \\
\hline B & 1058 & 1260 & 1273 & 1275 & 1035 \\
\hline C & 1315 & 1538 & 1502 & 1494 & 1323 \\
\hline
\end{tabular}

Ciclos: 100

Ciclos: 100
\begin{tabular}{|c|c|c|c|c|c|}
\hline & 1 & 2 & 3 & 4 & 5 \\
\hline A & 1643 & 1830 & 1673 & 1802 & 1631 \\
\hline B & 1280 & 1498 & 1520 & 1492 & 1256 \\
\hline C & 1560 & 1772 & 1777 & 1674 & 1510 \\
\hline
\end{tabular}

Ciclos: 300

\begin{tabular}{|c|c|c|c|c|c|}
\hline & 1 & 2 & 3 & 4 & 5 \\
\hline A & 1680 & 1875 & 1752 & 1853 & 1698 \\
\hline B & 1339 & 1550 & 1580 & 1579 & 1325 \\
\hline C & 1619 & 1855 & 1835 & 1757 & 1585 \\
\hline
\end{tabular}

Ciclos: 1000

\begin{tabular}{|c|c|c|c|c|c|}
\hline & 1 & 2 & 3 & 4 & 5 \\
\hline A & 1806 & 2025 & 1882 & 1932 & 1821 \\
\hline B & 1473 & 1663 & 1540 & 1641 & 1428 \\
\hline C & 1695 & 1995 & 1889 & 1832 & 1694 \\
\hline
\end{tabular}

Ciclos: 3000
\begin{tabular}{|c|c|c|c|c|c|}
\hline & 1 & 2 & 3 & 4 & 5 \\
\hline A & 1840 & 2062 & 1974 & 2005 & 1942 \\
\hline B & 1597 & 1702 & 1690 & 1714 & 1536 \\
\hline C & 1667 & 2023 & 1980 & 1932 & 1823 \\
\hline
\end{tabular}

Ciclos: 10000

\begin{tabular}{|c|c|c|c|c|c|}
\hline & 1 & 2 & 3 & 4 & 5 \\
\hline A & 2103 & 2326 & 2278 & 2276 & 2159 \\
\hline B & 1817 & 2027 & 1850 & 2083 & 1841 \\
\hline C & 1992 & 2290 & 2323 & 2304 & 2134 \\
\hline
\end{tabular}

Ciclos: 30000

\begin{tabular}{|c|c|c|c|c|c|}
\hline & 1 & 2 & 3 & 4 & 5 \\
\hline A & 2251 & 2483 & 2539 & 2584 & 2394 \\
\hline B & 1944 & 2229 & 2248 & 2423 & 2178 \\
\hline C & 2152 & 2474 & 2508 & 2593 & 2381 \\
\hline
\end{tabular}

LADO B - Placa 469

Ciclos: 0

\begin{tabular}{|c|c|c|c|c|c|}
\hline & 1 & 2 & 3 & 4 & 5 \\
\hline A & 1425 & 1530 & 1637 & 1600 & 1510 \\
\hline B & 1002 & 1215 & 1305 & 1240 & 1060 \\
\hline C & 1290 & 1435 & 1565 & 1460 & 1386 \\
\hline
\end{tabular}

Ciclos: 100

\begin{tabular}{|c|c|c|c|c|c|}
\hline & 1 & 2 & 3 & 4 & 5 \\
\hline A & 1545 & 1752 & 1850 & 1814 & 1698 \\
\hline B & 1260 & 1480 & 1490 & 1542 & 1376 \\
\hline C & 1458 & 1671 & 1790 & 1707 & 1532 \\
\hline
\end{tabular}

Ciclos: 300
\begin{tabular}{|c|c|c|c|c|c|}
\hline & 1 & 2 & 3 & 4 & 5 \\
\hline A & 1640 & 1850 & 1911 & 1890 & 1777 \\
\hline B & 1367 & 1570 & 1635 & 1621 & 1456 \\
\hline C & 1547 & 1781 & 1857 & 1844 & 1612 \\
\hline
\end{tabular}

Ciclos: 1000

\begin{tabular}{|c|c|c|c|c|c|}
\hline & 1 & 2 & 3 & 4 & 5 \\
\hline A & 1695 & 1965 & 2002 & 1987 & 1819 \\
\hline B & 1432 & 1627 & 1702 & 1676 & 1485 \\
\hline C & 1672 & 1846 & 1968 & 1896 & 1692 \\
\hline
\end{tabular}

Ciclos: 3000
\begin{tabular}{|c|c|c|c|c|c|}
\hline & 1 & 2 & 3 & 4 & 5 \\
\hline A & 1782 & 1984 & 2101 & 2080 & 1913 \\
\hline B & 1541 & 1721 & 1795 & 1804 & 1600 \\
\hline C & 1747 & 1942 & 2037 & 2025 & 1801 \\
\hline
\end{tabular}

Ciclos: 10000

\begin{tabular}{|c|c|c|c|c|c|}
\hline & 1 & 2 & 3 & 4 & 5 \\
\hline A & 1935 & 2142 & 2203 & 2177 & 1982 \\
\hline B & 1636 & 1833 & 1890 & 1874 & 1660 \\
\hline C & 1835 & 2044 & 2105 & 2080 & 1908 \\
\hline
\end{tabular}

Ciclos: 30000

\begin{tabular}{|c|c|c|c|c|c|}
\hline & 1 & 2 & 3 & 4 & 5 \\
\hline A & 2003 & 2194 & 2131 & 2132 & 2019 \\
\hline B & 1664 & 1897 & 1842 & 2050 & 1702 \\
\hline C & 1887 & 2081 & 2153 & 2146 & 1957 \\
\hline
\end{tabular}




\begin{tabular}{|l|l}
\hline & ESCOLA POLITÉCNICA DA UNIVERSIDANE DE SATO PAULO \\
DEPARTAMENTO DE ENGENHARIA DE TRANSPORTES & Laboratónio de Tecmologia de Pavimentação
\end{tabular}

Mistura 2G - 6,4\% Cap-20

$\mathbf{T}=60^{\circ} \mathrm{C}$

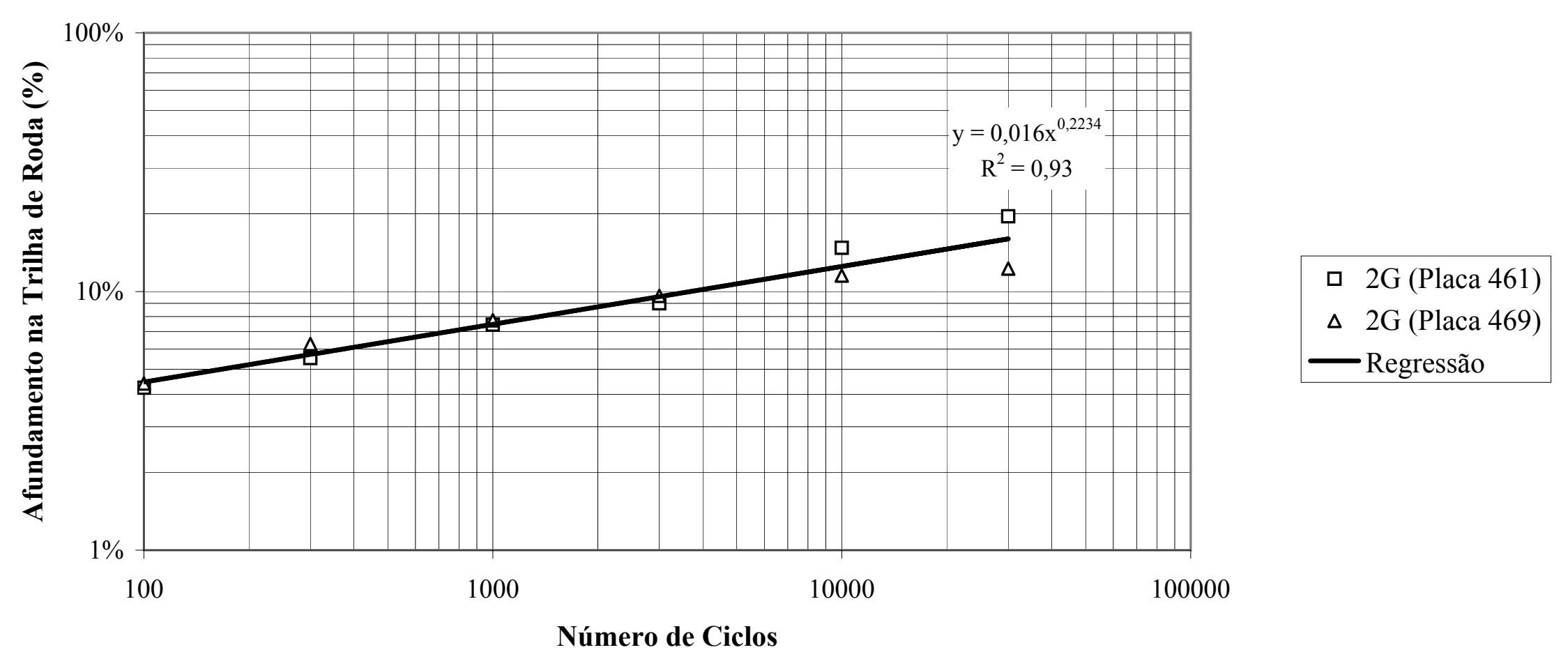


ESCOL A POL TÉCCNICA DA UNIVERSIDADE DE SÃO PAULO DEPARTAMENTO DE ENGENHARIA DE TRANSPORTES

Laboratónio de Tecnologia de Pavimentação

Identificação:

Temperatura do Ensaio:
Mistura 2F - 6,4\% Cap-20

$60^{\circ} \mathrm{C}$
LADO A - Placa 470

Ciclos: 0

\begin{tabular}{|c|c|c|c|c|c|}
\hline & 1 & 2 & 3 & 4 & 5 \\
\hline A & 1605 & 1700 & 1845 & 1740 & 1520 \\
\hline B & 1160 & 1300 & 1480 & 1410 & 1182 \\
\hline C & 1545 & 1750 & 1875 & 1750 & 1445 \\
\hline
\end{tabular}

Ciclos: 100
\begin{tabular}{|c|c|c|c|c|c|}
\hline & 1 & 2 & 3 & 4 & 5 \\
\hline A & 1800 & 1936 & 2058 & 1958 & 1731 \\
\hline B & 1388 & 1532 & 1724 & 1659 & 1445 \\
\hline C & 1735 & 1937 & 2061 & 1916 & 1645 \\
\hline
\end{tabular}

Ciclos: 300

\begin{tabular}{|c|c|c|c|c|c|}
\hline & 1 & 2 & 3 & 4 & 5 \\
\hline A & 1836 & 1975 & 2110 & 2013 & 1798 \\
\hline B & 1439 & 1567 & 1754 & 1713 & 1515 \\
\hline C & 1780 & 1970 & 2082 & 1954 & 1706 \\
\hline
\end{tabular}

Ciclos: 1000

\begin{tabular}{|c|c|c|c|c|c|}
\hline & 1 & 2 & 3 & 4 & 5 \\
\hline A & 1905 & 2057 & 2130 & 2077 & 1863 \\
\hline B & 1556 & 1694 & 1809 & 1757 & 1541 \\
\hline C & 1833 & 1985 & 2097 & 2003 & 1785 \\
\hline
\end{tabular}

Ciclos: 3000

\begin{tabular}{|c|c|c|c|c|c|}
\hline & 1 & 2 & 3 & 4 & 5 \\
\hline A & 1991 & 2147 & 2200 & 2145 & 1948 \\
\hline B & 1629 & 1756 & 1861 & 1827 & 1627 \\
\hline C & 1907 & 2081 & 2160 & 2045 & 1870 \\
\hline
\end{tabular}

Ciclos: 10000

\begin{tabular}{|c|c|c|c|c|c|}
\hline & 1 & 2 & 3 & 4 & 5 \\
\hline A & 2015 & 2169 & 2216 & 2169 & 1990 \\
\hline B & 1672 & 1797 & 1898 & 1872 & 1671 \\
\hline C & 1936 & 2091 & 2178 & 2094 & 1924 \\
\hline
\end{tabular}

Ciclos: 30000

Ciclos: 30000
\begin{tabular}{|c|c|c|c|c|c|}
\hline & 1 & 2 & 3 & 4 & 5 \\
\hline A & 2063 & 2200 & 2234 & 2196 & 2018 \\
\hline B & 1707 & 1829 & 1936 & 1903 & 1694 \\
\hline C & 1979 & 2257 & 2200 & 2112 & 1949 \\
\hline
\end{tabular}

LADO B - Placa 462

Ciclos: 0
\begin{tabular}{|c|c|c|c|c|c|}
\hline & 1 & 2 & 3 & 4 & 5 \\
\hline A & 1627 & 1835 & 1788 & 1672 & 1539 \\
\hline B & 1344 & 1472 & 1460 & 1436 & 1225 \\
\hline C & 1623 & 1660 & 1645 & 1588 & 1400 \\
\hline
\end{tabular}

Ciclos: 100
\begin{tabular}{|c|c|c|c|c|c|}
\hline & 1 & 2 & 3 & 4 & 5 \\
\hline A & 1797 & 1976 & 1939 & 1895 & 1710 \\
\hline B & 1532 & 1639 & 1624 & 1617 & 1407 \\
\hline C & 1773 & 1819 & 1768 & 1755 & 1521 \\
\hline
\end{tabular}

Ciclos: 300

\begin{tabular}{|c|c|c|c|c|c|}
\hline & 1 & 2 & 3 & 4 & 5 \\
\hline A & 1866 & 2031 & 1987 & 1964 & 1761 \\
\hline B & 1598 & 1689 & 1669 & 1668 & 1454 \\
\hline C & 1838 & 1862 & 1810 & 1812 & 1568 \\
\hline
\end{tabular}

Ciclos: 1000
\begin{tabular}{|c|c|c|c|c|c|}
\hline & 1 & 2 & 3 & 4 & 5 \\
\hline A & 1893 & 2038 & 2003 & 1978 & 1782 \\
\hline B & 1609 & 1699 & 1678 & 1670 & 1470 \\
\hline C & 1859 & 1882 & 1826 & 1830 & 1590 \\
\hline
\end{tabular}

Ciclos: 3000
\begin{tabular}{|c|c|c|c|c|c|}
\hline & 1 & 2 & 3 & 4 & 5 \\
\hline A & 1933 & 2070 & 2032 & 1992 & 1800 \\
\hline B & 1637 & 1718 & 1692 & 1678 & 1475 \\
\hline C & 1904 & 1905 & 1850 & 1848 & 1607 \\
\hline
\end{tabular}

Ciclos: 10000

\begin{tabular}{|c|c|c|c|c|c|}
\hline & 1 & 2 & 3 & 4 & 5 \\
\hline A & 2033 & 2162 & 2121 & 2066 & 1878 \\
\hline B & 1725 & 1797 & 1766 & 1746 & 1540 \\
\hline C & 2009 & 1988 & 1934 & 1926 & 1684 \\
\hline
\end{tabular}

Ciclos: 30000

\begin{tabular}{|c|c|c|c|c|c|}
\hline & 1 & 2 & 3 & 4 & 5 \\
\hline A & 2133 & 2254 & 2210 & 2140 & 1956 \\
\hline B & 1813 & 1876 & 1840 & 1814 & 1605 \\
\hline C & 2114 & 2071 & 2018 & 2004 & 1761 \\
\hline
\end{tabular}




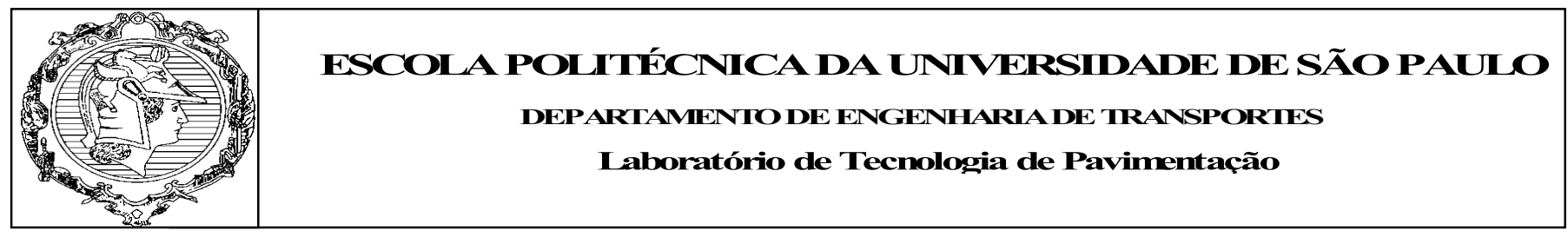

Mistura 2F - 6,4\% Cap-20

$\mathrm{T}=60^{\circ} \mathrm{C}$

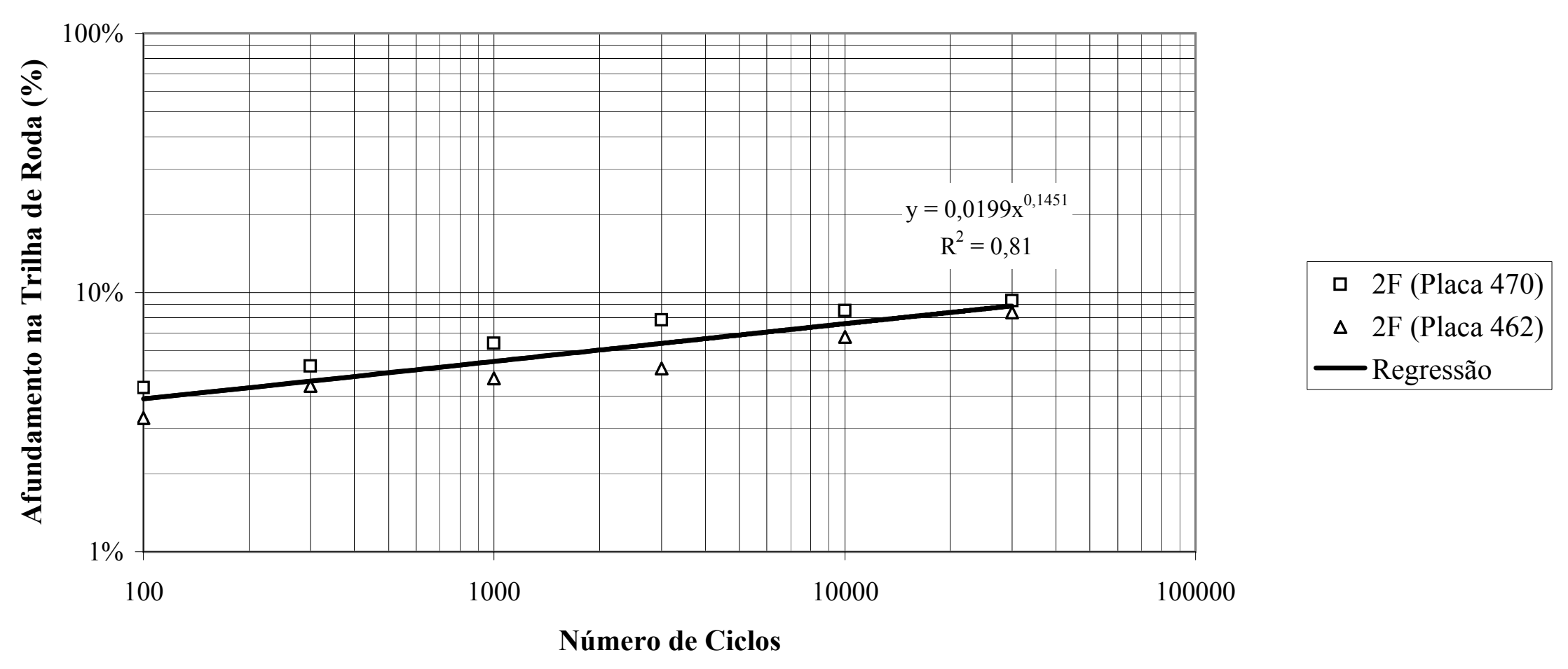


Identificação:

Mistura 1G - 6,3\% Cap-20

Temperatura do Ensaio:

$60^{\circ} \mathrm{C}$

\section{LADO A - Placa 471}

Ciclos: 0

\begin{tabular}{|c|c|c|c|c|c|}
\hline & 1 & 2 & 3 & 4 & 5 \\
\hline A & 1562 & 1745 & 1850 & 1736 & 1475 \\
\hline B & 1093 & 1327 & 1389 & 1377 & 1035 \\
\hline C & 1450 & 1530 & 1670 & 1580 & 1516 \\
\hline
\end{tabular}

Ciclos: 100

\begin{tabular}{|c|c|c|c|c|c|}
\hline & 1 & 2 & 3 & 4 & 5 \\
\hline A & 1700 & 1903 & 1981 & 1879 & 1584 \\
\hline B & 1240 & 1487 & 1546 & 1535 & 1159 \\
\hline C & 1552 & 1657 & 1806 & 1742 & 1620 \\
\hline
\end{tabular}

Ciclos: 300

\begin{tabular}{|c|c|c|c|c|c|}
\hline & 1 & 2 & 3 & 4 & 5 \\
\hline A & 1762 & 1964 & 2040 & 1932 & 1633 \\
\hline B & 1315 & 1578 & 1614 & 1598 & 1220 \\
\hline C & 1610 & 1734 & 1871 & 1808 & 1666 \\
\hline
\end{tabular}

Ciclos: 1000

Ciclos: 1000
\begin{tabular}{|c|c|c|c|c|c|}
\hline & 1 & 2 & 3 & 4 & 5 \\
\hline A & 1778 & 2013 & 2093 & 1969 & 1669 \\
\hline B & 1363 & 1638 & 1665 & 1638 & 1256 \\
\hline C & 1659 & 1777 & 1905 & 1863 & 1696 \\
\hline
\end{tabular}

Ciclos: 3000

\begin{tabular}{|c|c|c|c|c|c|}
\hline & 1 & 2 & 3 & 4 & 5 \\
\hline A & 1745 & 2059 & 2130 & 2005 & 1719 \\
\hline B & 1436 & 1690 & 1713 & 1679 & 1358 \\
\hline C & 1735 & 1824 & 1950 & 1926 & 1758 \\
\hline
\end{tabular}

Ciclos: 10000

\begin{tabular}{|c|c|c|c|c|c|}
\hline & 1 & 2 & 3 & 4 & 5 \\
\hline A & 1984 & 2165 & 2252 & 2080 & 1803 \\
\hline B & 1576 & 1812 & 1811 & 1766 & 1518 \\
\hline C & 1874 & 1974 & 2027 & 2012 & 1844 \\
\hline
\end{tabular}

Ciclos: 30000

\begin{tabular}{|c|c|c|c|c|c|}
\hline & 1 & 2 & 3 & 4 & 5 \\
\hline A & 2076 & 2240 & 2318 & 2122 & 1860 \\
\hline B & 1725 & 1900 & 1889 & 1812 & 1621 \\
\hline C & 1985 & 2054 & 2092 & 2060 & 1897 \\
\hline
\end{tabular}

LADO B - Placa 472

Ciclos: 0

\begin{tabular}{|c|c|c|c|c|c|}
\hline & 1 & 2 & 3 & 4 & 5 \\
\hline A & 1555 & 1761 & 1755 & 1628 & 1342 \\
\hline B & 1191 & 1465 & 1510 & 1350 & 975 \\
\hline C & 1475 & 1665 & 1785 & 1467 & 1340 \\
\hline
\end{tabular}

Ciclos: 100

\begin{tabular}{|c|c|c|c|c|c|}
\hline & 1 & 2 & 3 & 4 & 5 \\
\hline A & 1740 & 1935 & 1946 & 1810 & 1489 \\
\hline B & 1376 & 1604 & 1655 & 1507 & 1142 \\
\hline C & 1627 & 1800 & 1890 & 1579 & 1442 \\
\hline
\end{tabular}

Ciclos: 300
\begin{tabular}{|c|c|c|c|c|c|}
\hline & 1 & 2 & 3 & 4 & 5 \\
\hline A & 1790 & 1985 & 2007 & 1872 & 1554 \\
\hline B & 1416 & 1638 & 1690 & 1562 & 1207 \\
\hline C & 1648 & 1827 & 1930 & 1619 & 1515 \\
\hline
\end{tabular}

Ciclos: 1000

\begin{tabular}{|c|c|c|c|c|c|}
\hline & 1 & 2 & 3 & 4 & 5 \\
\hline A & 1857 & 2035 & 2066 & 1935 & 1610 \\
\hline B & 1480 & 1684 & 1715 & 1625 & 1255 \\
\hline C & 1728 & 1877 & 2006 & 1760 & 1343 \\
\hline
\end{tabular}

Ciclos: 3000

\begin{tabular}{|c|c|c|c|c|c|}
\hline & 1 & 2 & 3 & 4 & 5 \\
\hline A & 1962 & 2097 & 2139 & 2008 & 1698 \\
\hline B & 1553 & 1745 & 1780 & 1682 & 1341 \\
\hline C & 1789 & 1934 & 2048 & 1846 & 1458 \\
\hline
\end{tabular}

Ciclos: 10000

\begin{tabular}{|c|c|c|c|c|c|}
\hline & 1 & 2 & 3 & 4 & 5 \\
\hline A & 2058 & 2224 & 2232 & 2108 & 1817 \\
\hline B & 1645 & 1856 & 2013 & 1804 & 1450 \\
\hline C & 1876 & 1988 & 2114 & 1911 & 1592 \\
\hline
\end{tabular}

Ciclos: 30000

\begin{tabular}{|c|c|c|c|c|c|}
\hline & 1 & 2 & 3 & 4 & 5 \\
\hline A & 2112 & 2267 & 2270 & 2172 & 1891 \\
\hline B & 1697 & 1907 & 2040 & 1879 & 1607 \\
\hline C & 1925 & 2038 & 2158 & 1968 & 1683 \\
\hline
\end{tabular}




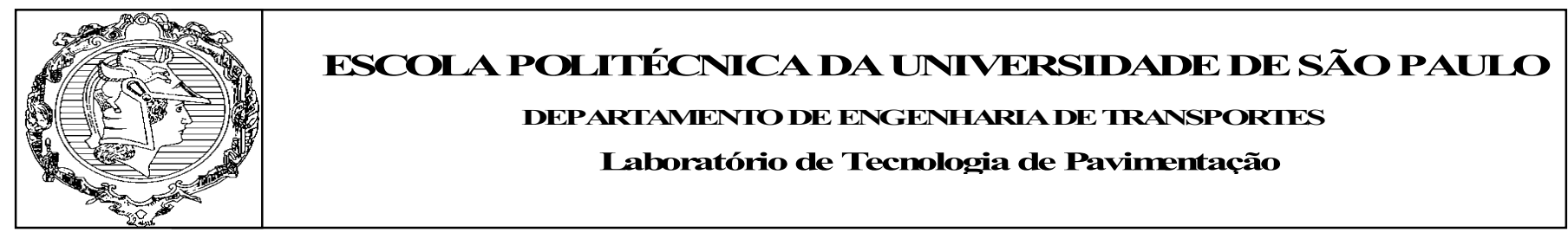

Mistura 1G - 6,3\% Cap-20

$\mathrm{T}=60^{\circ} \mathrm{C}$

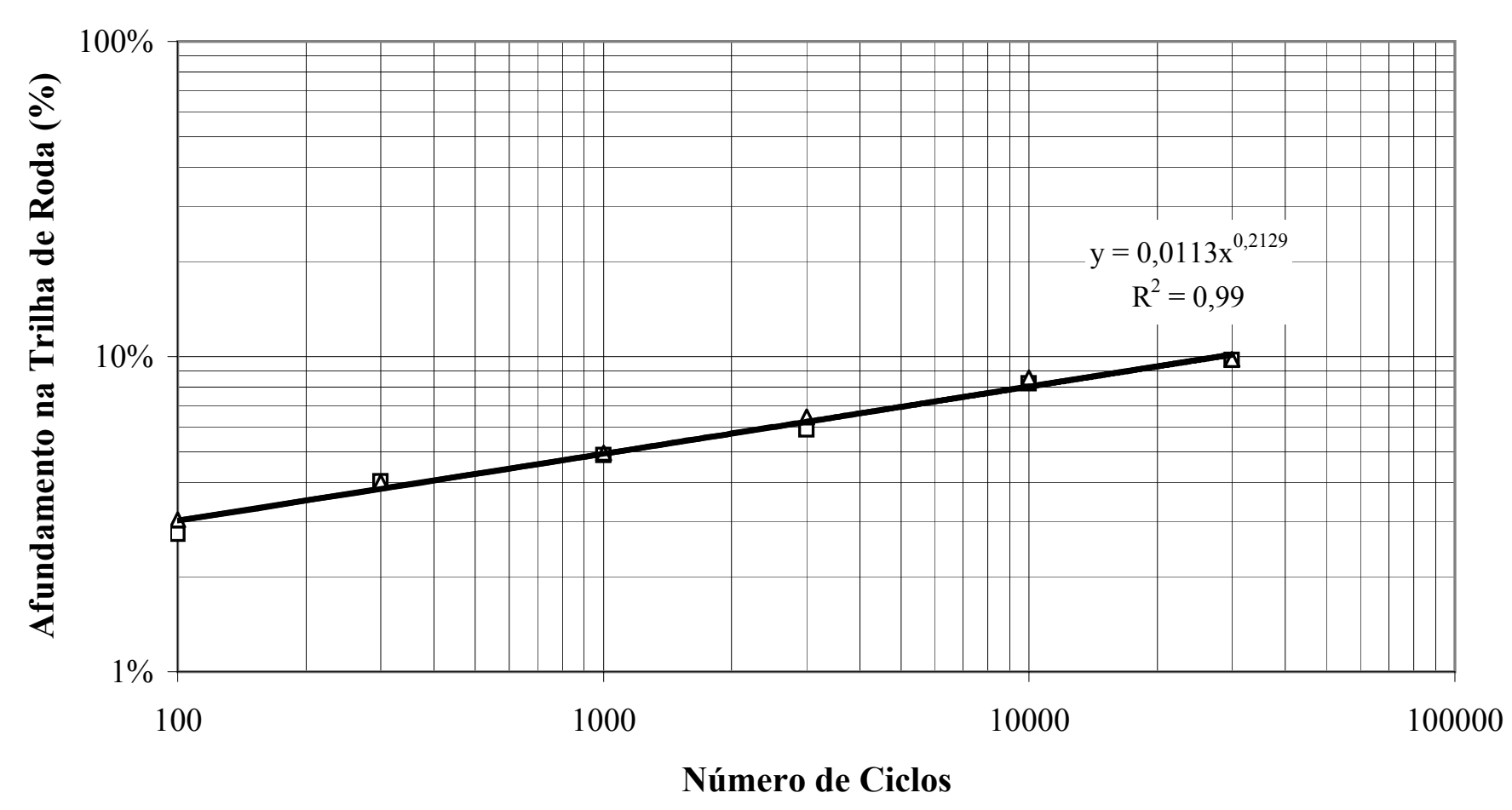

$1 \mathrm{G}$ (Placa 471)

$\Delta \quad 1 \mathrm{G}$ (Placa 472)

一 Regressão 
Identificação:

Mistura 1F - 6,3\% Cap-20

Temperatura do Ensaio:

$60^{\circ} \mathrm{C}$

\section{LADO A - Placa 474}

Ciclos: 0

\begin{tabular}{|c|c|c|c|c|c|}
\hline & 1 & 2 & 3 & 4 & 5 \\
\hline A & 1522 & 1598 & 1702 & 1576 & 1510 \\
\hline B & 1236 & 1510 & 1521 & 1372 & 1228 \\
\hline C & 1536 & 1595 & 1718 & 1594 & 1335 \\
\hline
\end{tabular}

Ciclos: 100

\begin{tabular}{|c|c|c|c|c|c|}
\hline & 1 & 2 & 3 & 4 & 5 \\
\hline A & 1688 & 1800 & 1894 & 1764 & 1706 \\
\hline B & 1477 & 1602 & 1596 & 1472 & 1338 \\
\hline C & 1649 & 1697 & 1805 & 1701 & 1464 \\
\hline
\end{tabular}

Ciclos: 300

\begin{tabular}{|c|c|c|c|c|c|}
\hline & 1 & 2 & 3 & 4 & 5 \\
\hline A & 1793 & 1850 & 1953 & 1824 & 1771 \\
\hline B & 1520 & 1643 & 1628 & 1507 & 1384 \\
\hline C & 1681 & 1736 & 1838 & 1729 & 1506 \\
\hline
\end{tabular}

Ciclos: 1000

Ciclos: 1000
\begin{tabular}{|c|c|c|c|c|c|}
\hline & 1 & 2 & 3 & 4 & 5 \\
\hline A & 1867 & 2020 & 2006 & 1881 & 1612 \\
\hline B & 1578 & 1679 & 1659 & 1555 & 1425 \\
\hline C & 1706 & 1774 & 1870 & 1781 & 1548 \\
\hline
\end{tabular}

Ciclos: 3000

\begin{tabular}{|c|c|c|c|c|c|}
\hline & 1 & 2 & 3 & 4 & 5 \\
\hline A & 1954 & 2112 & 2054 & 1933 & 1908 \\
\hline B & 1632 & 1727 & 1692 & 1601 & 1476 \\
\hline C & 1726 & 1819 & 1923 & 1802 & 1589 \\
\hline
\end{tabular}

Ciclos: 10000

\begin{tabular}{|c|c|c|c|c|c|}
\hline & 1 & 2 & 3 & 4 & 5 \\
\hline A & 2001 & 2169 & 2122 & 1963 & 1959 \\
\hline B & 1694 & 1783 & 1747 & 1654 & 1534 \\
\hline C & 1777 & 1876 & 1975 & 1856 & 1638 \\
\hline
\end{tabular}

Ciclos: 30000

\begin{tabular}{|c|c|c|c|c|c|}
\hline & 1 & 2 & 3 & 4 & 5 \\
\hline A & 2039 & 2202 & 2156 & 2002 & 1995 \\
\hline B & 1737 & 1820 & 1781 & 1684 & 1560 \\
\hline C & 1808 & 1911 & 2002 & 1888 & 1665 \\
\hline
\end{tabular}

LADO B - Placa 473

Ciclos: 0

\begin{tabular}{|c|c|c|c|c|c|}
\hline & 1 & 2 & 3 & 4 & 5 \\
\hline A & 1610 & 1550 & 1778 & 1628 & 1482 \\
\hline B & 1191 & 1303 & 1336 & 1471 & 1214 \\
\hline C & 1436 & 1502 & 1520 & 1561 & 1430 \\
\hline
\end{tabular}

Ciclos: 100

\begin{tabular}{|c|c|c|c|c|c|}
\hline & 1 & 2 & 3 & 4 & 5 \\
\hline A & 1768 & 1704 & 1924 & 1797 & 1627 \\
\hline B & 1363 & 1476 & 1481 & 1541 & 1387 \\
\hline C & 1592 & 1658 & 1540 & 1725 & 1593 \\
\hline
\end{tabular}

Ciclos: 300
\begin{tabular}{|c|c|c|c|c|c|}
\hline & 1 & 2 & 3 & 4 & 5 \\
\hline A & 1830 & 1763 & 1974 & 1855 & 1687 \\
\hline B & 1422 & 1526 & 1526 & 1586 & 1444 \\
\hline C & 1664 & 1716 & 1559 & 1778 & 1644 \\
\hline
\end{tabular}

Ciclos: 1000

\begin{tabular}{|c|c|c|c|c|c|}
\hline & 1 & 2 & 3 & 4 & 5 \\
\hline A & 1865 & 1814 & 2018 & 1894 & 1736 \\
\hline B & 1465 & 1572 & 1568 & 1632 & 1486 \\
\hline C & 1728 & 1717 & 1587 & 1822 & 1677 \\
\hline
\end{tabular}

Ciclos: 3000

\begin{tabular}{|c|c|c|c|c|c|}
\hline & 1 & 2 & 3 & 4 & 5 \\
\hline A & 1900 & 1864 & 2062 & 1932 & 1785 \\
\hline B & 1507 & 1618 & 1609 & 1678 & 1527 \\
\hline C & 1791 & 1717 & 1614 & 1865 & 1710 \\
\hline
\end{tabular}

Ciclos: 10000

Ciclos: 10000
\begin{tabular}{|c|c|c|c|c|c|}
\hline & 1 & 2 & 3 & 4 & 5 \\
\hline A & 1951 & 1911 & 2106 & 1984 & 1836 \\
\hline B & 1561 & 1658 & 1653 & 1727 & 1575 \\
\hline C & 1847 & 1864 & 1650 & 1911 & 1772 \\
\hline
\end{tabular}

Ciclos: 30000

\begin{tabular}{|c|c|c|c|c|c|}
\hline & 1 & 2 & 3 & 4 & 5 \\
\hline A & 1985 & 1933 & 2131 & 2017 & 1884 \\
\hline B & 1590 & 1658 & 1678 & 1860 & 1621 \\
\hline C & 1874 & 1884 & 1670 & 1940 & 1810 \\
\hline
\end{tabular}




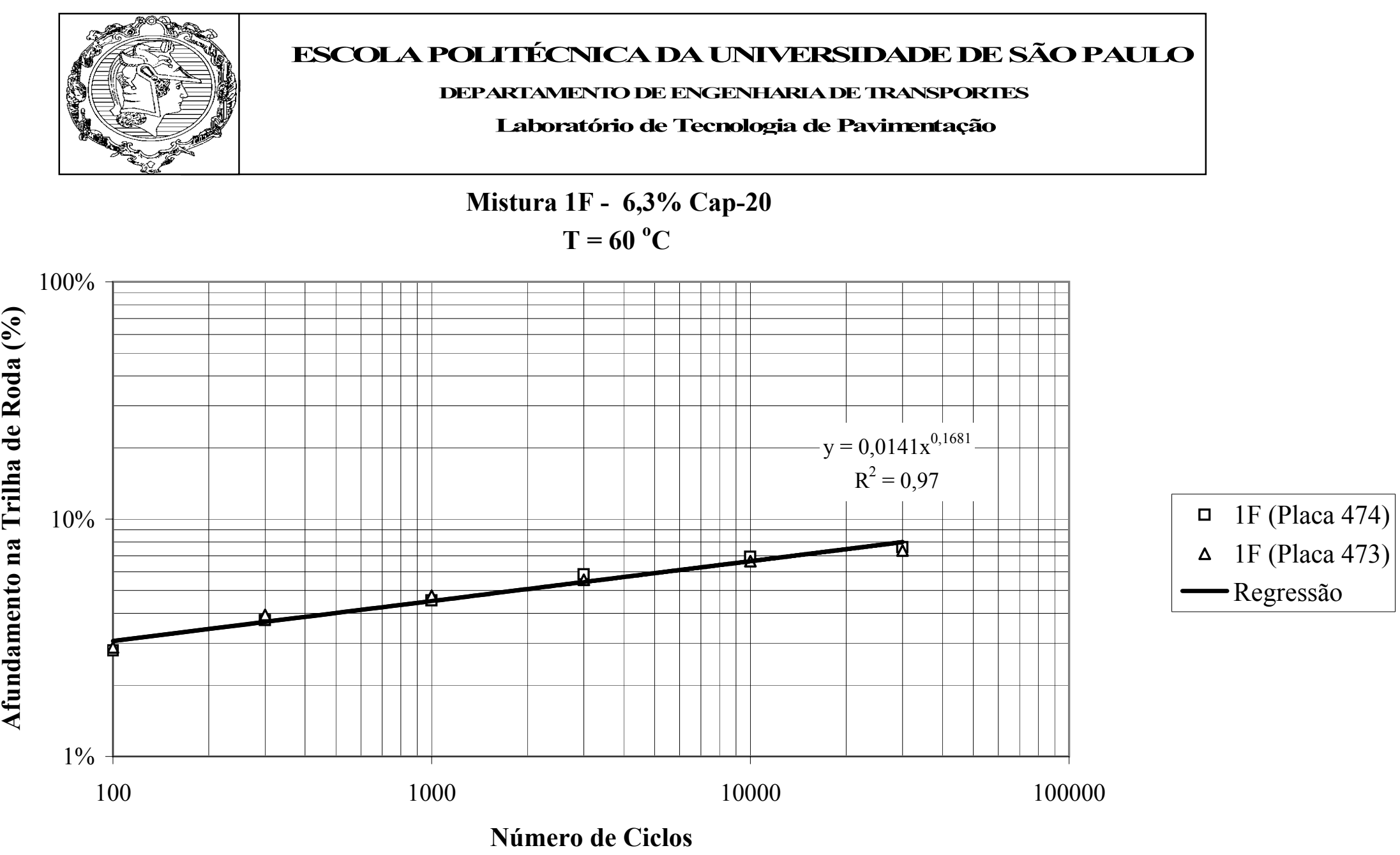

